Sergio Naruhiko Sakurai

\title{
Estudos em Economia do Setor Público e Nova Economia Política
}

Ribeirão Preto

2016 
Prof. Dr. Marco Antonio Zago

Reitor da Universidade de São Paulo

Prof. Dr. Dante Pinheiro Martinelli

Diretor da Faculdade de Economia, Administração e Contabilidade de Ribeirão Preto

Prof. Dr. Renato Leite Marcondes

Chefe do Departamento de Economia 
Sergio Naruhiko Sakurai

\title{
Estudos em Economia do Setor Público e Nova Econo- mia Política
}

\author{
Tese submetida ao Departamento de Eco- \\ nomia da Faculdade de Economia, Admi- \\ nistração e Contabilidade de Ribeirão Preto \\ da Universidade de São Paulo, como parte \\ dos requisitos para a obtenção do título de \\ Livre-Docente.
}

Faculdade de Economia, Administração e Contabilidade de Ribeirão Preto da Universidade de São Paulo (FEA-RP/USP)

Ribeirão Preto

2016 
Autorizo a reprodução e divulgação total ou parcial deste trabalho, por qualquer meio convencional ou eletrônico, para fins de estudo e pesquisa, desde que citada a fonte.

Sakurai, Sergio Naruhiko

Estudos em Economia do Setor Público e Nova Economia Política. Ribeirão Preto, 2016.

148 p. : il. ; $30 \mathrm{~cm}$

Tese (Livre-Docência) apresentada à Faculdade de Economia, Administração e Contabilidade de Ribeirão Preto da Universidade de São Paulo (FEA-RP/USP).

Área de concentração: Economia do Setor Público.

1. Economia do setor público 2. Nova Economia Política 3. Microeconometria 
Sergio Naruhiko Sakurai

\section{Estudos em Economia do Setor Público e Nova Econo- mia Política}

Tese submetida ao Departamento de Economia da Faculdade de Economia, Administração e Contabilidade de Ribeirão Preto da Universidade de São Paulo, como parte dos requisitos para a obtenção do título de Livre-Docente.

Trabalho aprovado em 21 de outubro de 2016

Prof. Dr. Reynaldo Fernandes

Prof. Dr. Fabiana Fontes Rocha

Prof. Dr. Fernando de Magalhães Papaterra Limongi

Prof. Dr. Luiz Guilherme Dácar da Silva Scorzafave 
À minha família, como sempre (inclusive àqueles que ainda estão por vir)... 


\section{Agradecimentos}

Nos agradecimentos de minha tese de doutorado, havia mencionado que o resultado daquele trabalho era resultante muito menos daquilo que fizera individualmente, e muito mais daquilo que aprendera com todas as pessoas com as quais havia convivido até então. Isto foi em junho de 2007. Hoje, em maio de 2016, ao finalizar esta tese de LivreDocência, entendo que aquele pensamento continua sendo muito verdadeiro. Assim, este agradecimento é novamente uma maneira humilde sincera de expressar meu sentimento de gratidão a algumas pessoas com as quais serei eternamente devedor.

Em primeiro lugar, agradeço à Universidade de São Paulo, pela possibilidade de concluir esta tese que, efetivamente, é função de tudo aquilo que pude aprender ao longo destes dezenove anos nos quais em seu ambiente tenho convivido. Continuo tendo a percepção de que uma instituição verdadeira só pode ser constituída com a presença de pessoas com propósitos sérios e convencidas de que a transmissão e difusão do conhecimento deve ser algo inerente ao ser humano.

Na FEA-RP/USP, instituição na qual realizei meu curso de graduação e na qual tenho atuado profissionalmente desde agosto de 2007, devo agradecimentos especiais aos meus ex-professores e hoje colegas de trabalho Prof. Dr. Rudinei Toneto Jr., Prof. Dr. Renato Leite Marcondes e Prof ${ }^{a}$. Dr ${ }^{a}$. Maria Christina Siqueira de Souza Campos, além dos amigos Prof. Dr. Luiz Guilherme Scorzafave, Prof. Dr. Cláudio Lucinda, Prof ${ }^{a}$. Dra . Elaine Pazello, Prof. Dr. André Lucirton Costa e Prof. Dr. Bruno Aurichio Ledo.

Ao meu orientador de Doutorado Prof. Dr. Naércio Aquino Menezes Filho e ao meu orientador de Mestrado e eterno amigo Prof. Dr. Amaury Patrick Gremaud, pelos inúmeros ensinamentos pessoais e profissionais, ao Prof. Dr. Gilberto Tadeu Lima, pelas discussões iniciais que despertaram meu interesse pela área da Nova Economia Política, e ao Prof. Dr. Marco Antônio Vasconcellos, pelas diversas oportunidades profissionais proporcionadas.

Aos alunos Ana Carolina Rosolen de Arruda, Caroline Beatriz Custódio da Silva, Celso Haruo Yodono, Jaqueline Rossali, Jenifer Barbosa, João Henrique de Lima Rissi, Luiza dos Santos Cubo Iglesias, Marina Cassiano Ribeiro e Pamela Generoso, pelo excelente trabalho de auxílio à pesquisa prestados durante meu período de trabalho na FEA-RP/USP.

Ao CNPq, pelos projetos de auxílio à pesquisa e pela bolsa de Produtividade em Pesquisa, e à Fapesp, também pelos projetos de auxílio à pesquisa mas, especialmente, pela bolsa de estágio de pesquisa no exterior, por meio do qual pude realizar meu período de visiting scholar na Universidade de Cambridge.

Aos professores Tiago Cavalcanti e Toke Aidt, pelo valioso suporte durante meu visiting scholar na Universidade de Cambridge.

À Klênio de Souza Barbosa, Paulo Roberto Arvate, Daniel Silva Júnior, Marcos Yamada Nakaguma, Raphaël Franck, Felix Grey, Jaakko Meriläinen e demais participantes do 2016 EPCS Meeting e do Political Economy Group, pelos valiosos comentários sobre 
os estudos apresentados nesta tese.

Aos meus colegas de trabalho André Pignata, Juliana Vitória, Sandra Dias e Selma Pontes pelo valioso auxílio na resolução dos "entraves burocráticos uspianos".

À secretaria de energia do estado de São Paulo, pela disponibilização dos dados de consumo de energia elétrica dos municípios do estado de São Paulo utilizados no quarto capítulo desta tese.

Aos meus alunos, pelas oportunidades diária de aprendizado e pela incrível paciência com este professor um tanto quanto confuso e atrapalhado.

Aos meus grandes amigos André Chagas, Bruno de Paula Rocha e Robson Rodrigues Pereira, e aos meus amigos do Oterá, em especial, Tijo sensei, Kazunori-san, Koiti \& Kenji Ogawa, Ossamu Yasunaga, Tia Dirce \& Renato Hanai, Ricardo \& Yuri Yamane e Rui Fukagawa, pela amizade que nem o tempo nem a distância são capazes de enfraquecer.

À minha família, em especial, à minha mãe Shizue, pelas sempre frequentes lições de sensibilidade, humildade, coragem, determinação e perseverança, e à minha irmã Mayumi à minha tia Yoshika, pelo equilíbrio e pela presença constante.

À minha esposa Martha Hanae Hiromoto e à nossa "filha" Kabuki, pela enorme paciência, pelo suporte e especialmente, pelo companheirismo leal e carinhoso.

Finalmente, e certamente o mais importante, a Deus, pela oportunidade de redigir este humilde agradecimento. 


\section{Resumo}

Esta tese apresenta três estudos empíricos aplicados ao Brasil nos quais interagem as áreas de Economia do Setor Público e Nova Economia Política. Em particular, o primeiro estudo tem como objetivo analisar em que medida o alinhamento partidário entre os chefes do executivo dos governos municipais com o chefe do executivo do governo federal e/ou com o chefe do executivo de seus respectivos governos estaduais exerce efeito sobre o montante recebido de transferências fiscais. Analisando um painel de municípios brasileiros entre 1999 e 2012 e aplicando um método intitulado "Diferenças triplas", os resultados sugerem que as Transferências de capital recebidas pelos municípios são maiores caso seus prefeitos sejam alinhados com os chefes de executivo de níveis superiores de governo. Contudo, o efeito do alinhamento sobre a rubrica Outras transferências correntes parece ser nulo. O segundo estudo, por sua vez, analisa em que medida o alinhamento partidário entre os chefes dos executivos municipais e estaduais com o governo federal influencia a obtenção de financiamento junto ao BNDES. Os resultados sugerem que municípios cujos prefeitos são alinhados com o governo federal apresentam maior probabilidade de solicitação e obtenção desses recursos. Em seu turno, estados cujos chefes de executivo são alinhados com o governo federal não só recebem financiamentos maiores relativamente a estados cujos governadores não são alinhados, como também sujeitos à menores taxas de juros e maiores prazos de amortização. Por fim, o terceiro estudo revisita a literatura de economic voting procurando investigar em que medida condições econômicas influenciam a decisão dos eleitores nas urnas. Dada a possibilidade de viés de endogeneidade nesta relação, o estudo explora variações exógenas das condições econômicas causadas pela instituição do programa de racionamento de energia elétrica, em 2001/2002, para analisar o desempenho do candidato incumbente às eleições presidenciais de 1998 e 2002 nos municípios dos estados de São Paulo e Paraná, os quais fizeram e não fizeram, respectivamente, parte do referido programa. Combinando os métodos de Diferenças-em-Diferenças e Variáveis Instrumentais, os resultados não só reforçam a percepção de que melhores condições econômicas efetivamente melhoram o desempenho eleitoral de candidatos incumbentes, mas também sugerem que esse efeito pode ter sido subestimado pela literatura até então existente.

Palavras-chave: Economia do Setor Público; Nova Economia Política; Microeconometria 


\begin{abstract}
This thesis presents three empirical studies applied to the Brazilian case interacting the areas of Economics of Public Sector and New Political Economy. In particular, the first study aims to investigate to what extent the partisan alignment between the chief executives of municipal governments with the chief executive of the federal government and/or with the executive chief of their respective state governments exert effect on the amount of fiscal transfers received. By exploring a panel of Brazilian municipalities between 1999 and 2012 by means of a method entitled "Triple Differences", our results suggest that capital transfers received by Brazilian municipalities are higher if their respective mayors are aligned with superior levels of government. However, the effect on the discretionary portion of current transfers appears to be negligible. The second study, in turn, investigates to what extent the partisan alignment between the chief executive of Brazilian municipalities and states with the federal government influences loans provided by the Brazilian Development Bank (BNDES). Our results suggest that local governments whose executive chief is aligned with the federal government are more likely to request and obtain credit. In turn, state governments whose executive chief is aligned with the federal government seem not only to receive higher funding comparatively to states whose governors are not aligned, but also subject to lower interest rates and longer mortgage amortization period. Finally, the third study revisits the economic voting literature and investigates to what extent economic conditions influence the decision of voters at the polls. Given that this relationship may suffer from endogeneity bias, this study explores exogenous variations in economic conditions caused by the electricity rationing program, instituted in Brazil in 2001/2002, to investigate the performance of the incumbent candidate in the presidential elections of 1998 and 2002 in municipalities belonging to São Paulo and Paraná states. By combining Differences-in-Differences and Instrumental Variables methods, our results not only suggest that favourable economic conditions effectively increase the proportion of votes received by incumbent candidates, but also that this effect may have been underestimated by the existing literature.
\end{abstract}

Key-words: Economics of Public Sector; New Political Economy; Microeconometrics 


\section{Lista de ilustrações}

Figura 1 - Porcentagem de municípios alinhados com o governo federal e/ou estadual 25

Figura 2 - Outras transferências correntes . . . . . . . . . . . . . 27

Figura 3 - Transferências de capital . . . . . . . . . . . . . . . 27

Figura 4 - Valor do financiamento (total) - municípios . . . . . . . . . . 70

Figura 5 - Valor do financiamento (reembolsável) - municípios . . . . . . . . 70

Figura 6 - Taxa de juros - municípios . . . . . . . . . . . . . . 70

Figura 7 - Prazo de amortização - municípios . . . . . . . . . . . . . 71

Figura 8 - Prazo de carência - municípios . . . . . . . . . . . 71

Figura 9 - Valor do financiamento (total) - estados . . . . . . . . . . . 78

Figura 10 - Valor do financiamento (reembolsável) - estados . . . . . . . . . . . 78

Figura 11 - Taxa de juros - estados . . . . . . . . . . . . . . . . . . . . 79

Figura 12 - Prazo de amortização - estados . . . . . . . . . . . . . . . . . 79

Figura 13 - Prazo de carência - estados . . . . . . . . . . . . . . . . . . 79

Figura 14 - Consumo médio de energia, por tipo de usuário e ano . . . . . . . . . . 96

Figura 15 - Quantidade de usuários, por tipo de usuário e ano . . . . . . . . . . . . 96

Figura 16 - Indicadores econômicos . . . . . . . . . . . . . . . . . . . 97

Figura 17 - Indicadores econômicos (continuação) . . . . . . . . . . . . . . . . 97

Figura B.1-Fragmentação de votos - municípios . . . . . . . . . . . . . . . . . . 134

Figura B.2-Distância da razão DCL / RCL - municípios . . . . . . . . . . . . . . . 134

Figura B.3-Distância da razão Pessoal / RCL - municípios . . . . . . . . . . . . 135

Figura B.4-Percentagem de jovens - municípios . . . . . . . . . . . . . . . . . . . . . . . . . . . . . . . . .

Figura B.5-Percentagem urbana - municípios . . . . . . . . . . . . . . 135

Figura B.6-População (ln) - municípios . . . . . . . . . . . . . . . . . 136

Figura B.7-Testes de densidade - municípios . . . . . . . . . . . . . . . . . . . . . . . . . . . . . . . . . . .

Figura B.8-Fragmentação de votos - estados . . . . . . . . . . . . . . . . . 140

Figura B.9-Distância da razão DCL / RCL - estados . . . . . . . . . . . . . . . . 140

Figura B.10-Distância da razão Pessoal / RCL - estados . . . . . . . . . . . . . . 140

Figura B.11-Percentagem de jovens - estados . . . . . . . . . . . . . . . . . . . . 141

Figura B.12-Percentagem urbana - estados . . . . . . . . . . . . . . . . . . 141

Figura B.13-População (ln) - estados . . . . . . . . . . . . . . . . . . . 141

Figura B.14-Testes de densidade - estados . . . . . . . . . . . . . . . . . . . . . 144 


\section{Lista de tabelas}

Tabela 1 - Variação do alinhamento ao longo dos anos da amostra . . . . . . . . . 26

Tabela 2 - Procedimento Cross Section - Outras transferências correntes . . . . 30

Tabela 3 - Procedimento Time D - Outras transferências correntes . . . . . . . . 31

Tabela 4 - Procedimento Grantor D - Outras transferências correntes . . . . . . . 32

Tabela 5 - Procedimento Triple D-Outras transferências correntes . . . . . . . . 33

Tabela 6 - Procedimento Cross Section - Transferências de capital . . . . . . . . . 34

Tabela 7 - Procedimentos Time D, Grantor D e Triple D - Transferências de capital 35

Tabela 8 - Outras transferências correntes - alinhamento com coligação ou ministros 39

Tabela 9 - Transferências de capital do governo federal - alinhamento com coligação ou ministros . . . . . . . . . . . . . . . . . . . . . . 40 40

Tabela 10 - Outras transferências correntes - municípios sem mudança de partido do prefeito ........................ . . . 41

Tabela 11 - Transferências de capital - municípios sem mudança de partido do prefeito 42

Tabela 12 - Quantidade de municípios contemplados com financiamentos do BNDES, por unidade da federação e ano . . . . . . . . . . . . . . 59

Tabela 13 - Estados contemplados com financiamentos do BNDES, por unidade da federação e ano . . . . . . . . . . . . . . . . . . 6 60

Tabela 14 - Quantidade de municípios e estados contemplados com financiamentos do BNDES, por ano e tipo de alinhamento . . . . . . . . . . . . 61

Tabela 15 - Estatísticas descritivas . . . . . . . . . . . . . . . . 62

Tabela 16 - Alinhamento partidário e financiamento do BNDES aos municípios viés de seleção - alinhamento com partidos da coligação presidencial . . 64

Tabela 17 - Alinhamento partidário e financiamento do BNDES aos municípios viés de seleção - alinhamento com partidos da coligação e/ou dos ministros 65

Tabela 18 - Alinhamento partidário e financiamento do BNDES aos municípios -

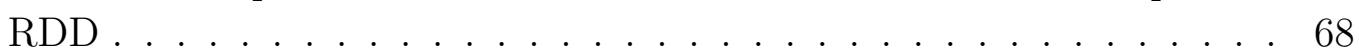

Tabela 19 - Testes não paramétricos de descontinuidade - municípios . . . . . . . . 69

Tabela 20 - Alinhamento partidário e financiamento do BNDES aos estados - viés de seleção - alinhamento com partidos da coligação presidencial . . . . 72

Tabela 21 - Alinhamento partidário e financiamento do BNDES aos estados - viés de seleção - alinhamento com partidos da coligação e/ou dos ministros 73

Tabela 22 - Alinhamento partidário e financiamento do BNDES aos estados - RDD 75

Tabela 23 - Testes não paramétricos de descontinuidade - estados . . . . . . . . . 77

Tabela 24 - Proporção de votos recebida pelo partido incumbente, por estado e eleição . . . . . . . . . . . . . . . . . . . . . 9 95

Tabela 25 - Efeito das condições econômicas sobre o desempenho eleitoral - forma reduzida - efeitos fixos . . . . . . . . . . . . . . . . . . 99

Tabela 26 - Efeito do programa de racionamento sobre o consumo de energia elétrica, por tipo de consumidor - Diferenças-em-Diferenças - efeitos fixos 100

Tabela 27 - Efeito do programa de racionamento sobre condições econômicas Diferenças-em-Diferenças - efeitos fixos . . . . . . . . . . 103 
Tabela 28 - Efeito do programa de racionamento sobre condições econômicas Diferenças-em-Diferenças - efeitos fixos (continuação) . . . . . . . . . . 104

Tabela 29 - Efeito das condições econômicas sobre a performance eleitoral - Variável instrumental e OLS - efeitos fixos . . . . . . . . . . . . . . . . . 109

Tabela 30 - Efeito das condições econômicas sobre a performance eleitoral - Variável instrumental e OLS - efeitos fixos - faixas populacionais selecionadas110

Tabela A.1-Procedimentos Cross Section e Grantor D - Outras transferências correntes do governo federal - alinhamento com coligação ou ministros . . 124

Tabela A.2-Procedimento Time D - Outras transferências correntes do governo federal - alinhamento com coligação ou ministros . . . . . . . . . . . 125

Tabela A.3-Procedimento Triple D - Outras transferências correntes do governo federal - alinhamento com coligação ou ministros . . . . . . . . . . . . 125

Tabela A.4-Procedimento Cross Section - Transferências de capital do governo federal - alinhamento com coligação ou ministros . . . . . . . . . . . . 126

Tabela A.5-Procedimentos Time D, Grantor D e Triple D - Transferências de capital do governo federal - alinhamento com coligação ou ministros . . . 127

Tabela A.6-Procedimento Cross Section - Outras transferências correntes - municípios sem mudanças de partido do prefeito . . . . . . . . . . . 128

Tabela A.7-Procedimento Time D - Outras transferências correntes - municípios sem mudanças de partido do prefeito . . . . . . . . . . . . . . 129

Tabela A.8-Procedimento Grantor D - Outras transferências correntes - municípios sem mudanças de partido do prefeito . . . . . . . . . . . . . . 130

Tabela A.9-Procedimento Triple D - Outras transferências correntes - municípios sem mudanças de partido do prefeito . . . . . . . . . . . . . . . 131

Tabela A.10-Procedimento Cross Section - Transferências de capital - municípios sem mudanças de partido do prefeito . . . . . . . . . . . . . . . . 132

Tabela A.11-Procedimentos Time D, Grantor D e Triple D - Transferências de capital - municípios sem mudanças de partido do prefeito . . . . . . . 133

Tabela B.1-Testes não paramétricos de descontinuidade das variáveis de controle municípios . . . . . . . . . . . . . . . . . . 137

Tabela B.2 - Testes não paramétricos adicionais de descontinuidade - municípios . . 138

Tabela B.3 - Alinhamento partidário e financiamento do BNDES aos estados - RDD - margens de vitória iguais a $10 \%$ e $20 \%$ ao redor do threshold . . . . . 139

Tabela B.4-Testes não paramétricos de descontinuidade das variáveis de controle estados . . . . . . . . . . . . . . . . . . 142

Tabela B.5 - Testes não paramétricos adicionais de descontinuidade - estados . . . . 143

Tabela C.1 - Efeito do programa de racionamento sobre condições econômicas Diferenças-em-Diferenças clássico - efeitos fixos . . . . . . . . . . . 146

Tabela C.2 -Efeito do programa de racionamento sobre condições econômicas Diferenças-em-Diferenças - efeitos fixos - média dos dois últimos anos do mandato . . . . . . . . . . . . . . . . . . . . . 147

Tabela C.3 - Efeito do programa de racionamento sobre condições econômicas Diferenças-em-Diferenças - efeitos fixos - variação proporcional entre a média dos dois primeiros e a média dos dois últimos anos do mandato 148 
Sumário

INTRODUÇÃO DA TESE . . . . . . . . . . . . . . . . . . . 14

ALINHAMENTO PARTIDÁRIO E TRANSFERÊNCIAS FISCAIS: UMA ANÁLISE PARA OS MUNICÍPIOS BRASILEIROS VIA MÉTODO DE DIFERENÇAS TRIPLAS . . . . . . . . . . . . . . 16 Introdução . . . . . . . . . . . . . . . . . . . . . 16

Revisão da literatura

Procedimentos metodológicos . . . . . . . . . . . . . . . . 20

Resultados . . . . . . . . . . . . . . . . . . . . . 28

Outras transferências correntes . . . . . . . . . . . . . . . . . . . . . . 28

Transferências de capital . . . . . . . . . . . . . . . . . . . . 31

Análise de robustez . . . . . . . . . . . . . . . . . . . . . . . . . . . . . . . . . . 36

ALINHAMENTO PARTIDÁRIO E EMPRÉSTIMOS OFICIAIS VIA BNDES: UMA ANÁLISE PARA OS ESTADOS E MUNICÍPIOS BRASILEIROS . . . . . . . . . . . . . . . . . 45

Revisão da literatura . . . . . . . . . . . . . . . . . . . . . 46

Uma breve revisão da literatura sobre o BNDES . . . . . . . . . . . . . . 46

Uma breve revisão da literatura sobre bancos públicos e fatores políticos . . 49

Procedimentos metodológicos . . . . . . . . . . . . . . . 53

Resultados . . . . . . . . . . . . . . . . . . . . . 61

Análise dos municípios . . . . . . . . . . . . . . . . . . . 62

3.4.1.1 Método de viés de seleção . . . . . . . . . . . . . . . . . . 62

3.4.1.2 Método RDD . . . . . . . . . . . . . . . . . 63

3.4.1.3 Sobre a validade dos resultados obtidos via RDD . . . . . . . . . . . . . 66

3.4.2 Análise dos estados . . . . . . . . . . . . . . . . . 69

3.4.2.1 Método de viés de seleção . . . . . . . . . . . . . . . . . . . . . 69

3.4.2.2 Método RDD . . . . . . . . . . . . . . . . . . . 73

3.4.2.3 Sobre a validade dos resultados obtidos via RDD . . . . . . . . . . . . . . 76

3.5 Considerações finais do capítulo . . . . . . . . . . . . . . 78

4 CONDIÇÕES ECONÔMICAS E DESEMPENHO ELEITORAL: NOVAS EVIDÊNCIAS A PARTIR DE UM QUASE-EXPERIMENTO . 82

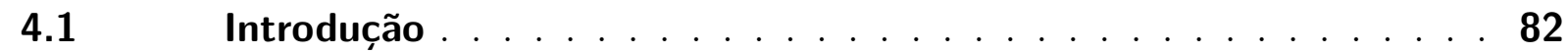

4.2 Revisão da literatura . . . . . . . . . . . . . . . 83

4.3 O programa de racionamento de 2001-2002 . . . . . . . . 86

$4.4 \quad$ Procedimentos metodológicos . . . . . . . . . . . . . 90

$4.5 \quad$ Resultados . . . . . . . . . . . . . . . . . . . . 98

4.6 Considerações finais do capítulo . . . . . . . . . . . . . . . 107

5 CONSIDERAÇÕES FINAIS DA TESE . . . . . . . . . . . . 111

REFERÊNCIAS . . . . . . . . . . . . . . . 113 


\section{Introdução da tese}

Este trabalho representa a tese apresentada pelo candidato Sergio Naruhiko Sakurai para obtenção do título de Livre-Docente junto ao Departamento de Economia da Faculdade de Economia, Administração e Contabilidade de Ribeirão Preto, na área de Economia do Setor Público e Economia Política.

Este trabalho está dividido em três capítulos, cada um representando um estudo distinto em que interagem as áreas de Economia do Setor Público e Nova Economia Política ${ }^{1}$, com aplicações empíricas para os estados e municípios brasileiros. O primeiro estudo tem como objetivo analisar a influência do alinhamento partidário entre as diferentes instâncias da administração pública sobre o montante de transferências governamentais. Em particular, procura-se analisar como o alinhamento partidário do chefe do executivo municipal com o chefe de executivo de seu respectivo governo estadual e/ou com o governo federal afetam o montante de recursos recebidos via transferências governamentais. Para tal, é adotado um procedimento ainda não aplicado para o caso brasileiro, que envolve triplas diferenças: a ideia é explorar não só as variações do alinhamento partidário que ocorrem ao longo do tempo e entre municípios diferentes (o que contemplaria dois tipos de variação), mas também as variações decorrentes da possibilidade de um município estar (ou não estar) alinhado com seu respectivo governo estadual, e estar (ou não estar) alinhado com o governo federal. Além de fazer uso deste procedimento, este estudo procura contribuir com a literatura ao analisar explicitamente as transferências recebidas pelos municípios a partir dos governos estaduais, as quais têm recebido pouca atenção dos estudos recentemente realizados para o caso brasileiro. De forma geral, os resultados obtidos indicam que as Transferências de capital recebidas pelos municípios do país tendem a ser maiores caso esses sejam alinhados com o governo federal ou com seus respectivos governos estaduais. Contudo, a rubrica Outras transferências correntes parece ser menos suscetíveis ao efeito do alinhamento partidário.

O segundo estudo, por sua vez, tem como objetivo analisar se o alinhamento partidário dos chefes dos executivos dos municípios e estados brasileiros com o governo federal exerce alguma influência sobre o montante ou sobre as condições de financiamento obtido junto ao Banco Nacional de Desenvolvimento Econômico e Social (BNDES). Este estudo tem motivação semelhante ao apresentado no capítulo 2, mas ao invés de analisar um canal direto de interação do governo federal com os governos estaduais e municipais (qual seja, as transferências fiscais), procura analisar um canal indireto, por meio da oferta de crédito subsidiado via bancos oficiais. Em particular, este estudo explora dados de empréstimos tomados por municípios e estados brasileiros junto ao referido banco e faz uso de estimações do tipo Heckman e do procedimento de regressão descontínua (Regression Discontinuity Design, doravante RDD). Muito embora existam estudos semelhantes analisando o efeito do alinhamento partidário sobre o crédito provido por bancos comerciais públicos, este estudo procura contribuir com a literatura ao analisar especificamente a

1 Este termo é utilizado, entre outros, por Romer (2012), para fazer menção à área de pesquisa na qual interagem elementos da Teoria Econômica e da Ciência Política e distingui-la da Economia Política Clássica. 
atuação do BNDES via provisão de financiamento subsidiado aos municípios e estados do país. Os resultados indicam que estados alinhados com o governo federal tendem não só a receber empréstimos de maior montante frente aos estados não-alinhados, mas também sujeitos à melhores condições de devolução. No caso dos municípios, por sua vez, os efeitos do alinhamento parecem não se dar sobre o montante ou sobre as condições do financiamento em si, mas sim sobre a probabilidade de solicitação por parte dos municípios.

Por fim, o terceiro estudo procura contribuir com uma literatura já bastante ampla, denominada economic voting, que discute como condições econômicas afetam o desempenho eleitoral de candidatos ou partidos incumbentes. Mais especificamente, este estudo procura contribuir com a literatura ao explorar variações exógenas das condições econômicas causadas pela instituição do programa de racionamento de energia elétrica entre junho de 2001 e fevereiro de 2002. Em particular, este estudo combina os métodos de Diferenças-em-Diferenças (doravante Diff-in-Diff) e Variáveis Instrumentais (doravante IV), em que os municípios do estado de São Paulo, submetidos ao racionamento, formam o grupo de tratamento, ao passo que os municípios do estado do Paraná, não submetidos ao racionamento, formam o grupo de controle. Os resultados obtidos não só sugerem que melhores condições econômicas são efetivamente convertidas pelos eleitores em mais votos ao candidato incumbente, mas também sugerem que esse efeito pode ser maior do que a literatura tem evidenciado até o momento.

Esta tese procura contribuir com uma literatura que tem crescido de forma significativa ao longo dos últimos anos, envolvendo inclusive diversos estudos aplicados ao caso brasileiro. Por envolver a interação entre diversos elementos de Economia do setor público e Ciência Política, essa literatura é não só relevante em termos puramente acadêmicos, mas também e principalmente pelo fato da mesma trazer resultados relevantes para o processo de formulação, execução, acompanhamento e reforma de políticas públicas que são, em grande parte, postas em práticas justamente por entes da administração pública direta. Portanto, entender os incentivos dos diversos agentes envolvidos e encontrar evidências e fatos estilizados é fundamental para esse processo.

Em cada um dos três estudos desta tese é apresentada tanto uma breve revisão da literatura específica a cada um dos mesmos como uma descrição mais detalhada dos dados utilizados e dos métodos econométricos empregados. Cada capítulo também apresenta uma seção conclusiva, sendo que o Capítulo 5 apresenta as considerações finais da tese como um todo. 


\section{Alinhamento partidário e transferências fiscais: uma análise para os municípios brasileiros via método de diferenças triplas}

\subsection{Introdução}

As transferências governamentais representam um dos principais mecanismos associados ao federalismo fiscal e no caso do Brasil em particular, é sabido que esses recursos desempenham papel relevante no seu sistema fiscal, uma vez que representam parte significativa dos recursos disponíveis pelos estados e, em especial, pelos municípios.

A literatura clássica de finanças públicas considera uma série de razões teóricas para a existência das transferências governamentais: conforme Musgrave (1959), Oates (1972) e Rosen e Gayer (2010), entre outros, as transferências são importantes para financiar gastos públicos que geram externalidades positivas tais que, se financiados unicamente por governos locais, poderiam ser providos em nível sub-ótimo. Outra justificativa está associada à eventual cobrança de impostos locais ineficientes quando da ausência de um mecanismo centralizado de tributação com a posterior distribuição de recursos. Finalmente, o argumento da equidade estabelece a necessidade de se corrigir, via atuação do governo central, desequilíbrios existentes entre as unidades locais, de tal forma que o desenvolvimento das diversas regiões de um país ocorresse de forma homogênea. Seja como for, nota-se que esta corrente da literatura sobre as transferências fiscais considera razões de caráter normativo como critérios para a alocação desses recursos. Na prática, contudo, outros fatores podem afetar o comportamento das transferências governamentais: neste estudo, explora-se um fator particular, qual seja, a possibilidade de influência político-partidária.

Este capítulo da tese procura contribuir com a literatura ao trazer novas evidências de que o alinhamento partidário entre os diferentes níveis de governo exerce influência sobre as transferências fiscais, especialmente em função da alta importância desses recursos para o orçamento dos municípios brasileiros ${ }^{2}$. Para tal, este estudo explora um painel de municípios brasileiros entre os anos de 1999 a 2012 contemplando as transferências recebidas não só a partir do governo federal, mas também a partir de seus respectivos governos estaduais, tendo como base o método proposto por Sole-Olle e Sorribas-Navarro (2008), que explora três fontes de variação do alinhamento partidário entre os diferentes níveis de governo: em primeiro lugar, há variação entre municípios quanto ao alinhamento com os governos superiores, pois um município pode estar alinhado com o governo estadual, por exemplo, mas outro município, não. Em segundo lugar, há variação intra-município quanto ao alinhamento, dado que a existência de mandatos distintos faz com que um município esteja alinhado com governo estadual, por exemplo, em um primeiro período, mas em um segundo, não mais esteja. Finalmente, em terceiro lugar, um dado município pode estar alinhado com seu governo estadual, mas ao mesmo tempo, pode não estar alinhado com o governo federal. Assim, a principal contribuição do método proposto por

\footnotetext{
2 A relevância das transferências fiscais pode ser estudada em um contexto mais amplo, que envolve a própria divisão de poderes entre os diferentes níveis de governo do Brasil. O recente estudo de Arretche, Schlegel e Ferrari (2015) apresenta uma interessante discussão a respeito deste tema.
} 
Sole-Olle e Sorribas-Navarro (2008) é a adoção de um procedimento que contempla esses três tipos de variação. Esse método permite estimar o efeito das variações no alinhamento sobre as variações das transferências oriundas de instâncias alinhadas vis-à-vis variações das transferências oriundas de instâncias superioras não alinhadas, de modo a controlar pela presença de efeitos fixos ao mesmo em que se explora todas as variações possíveis do alinhamento. Desta forma, esse procedimento pode ser visto como mais abrangente e tecnicamente mais rigoroso que os métodos já empregados pela literatura para investigar o efeito do alinhamento partidário sobre as transferências governamentais. Ademais, este estudo também procura contribuir com a literatura ao analisar não só as transferências providas pelo governo federal, mas também aquelas providas pelos governos estaduais, as quais têm recebido pouca atenção dos estudos aplicados ao Brasil que versam sobre este tema.

Explorando dois tipos específicos de transferências, quais sejam, as Outras transferências correntes e as Transferências de capital, os resultados obtidos neste estudo indicam que a segunda dessas duas transferências parece ser especialmente sensível ao alinhamento partidário, isto é, municípios alinhados com o governo federal e/ou com seu respectivo governo estadual tendem a receber maiores montantes de Transferências de capital relativamente aos municípios não alinhados. Estes resultados são corroborados quando são realizados dois exercícios alternativos: no primeiro deles, utiliza-se uma medida mais geral de alinhamento partidário com o governo federal, em que um município é considerado alinhado com o governo federal não só caso o partido de seu prefeito seja membro da coligação vencedora das eleições presidenciais, mas também caso tenha administrado algum ministério federal; no segundo exercício, por sua vez, consideram-se apenas aqueles municípios em que não houve mudança de partido do chefe do executivo local. Já para as Outras transferências correntes, os resultados obtidos sugerem pouco efeito do alinhamento partidário.

Além desta breve introdução, este estudo esta estruturado da seguinte forma: a seção 2.2 apresenta uma breve revisão da literatura, ao passo que a seção 2.3 apresenta a descrição dos procedimentos metodológicos e dos dados utilizados. A seção 2.4, por sua vez, apresenta os resultados das estimações. Por fim, as considerações finais são apresentadas na seção 2.5 .

\subsection{Revisão da literatura}

Conforme discutido anteriormente, existe uma literatura de caráter normativo que discute as transferências fiscais. Contudo, representada no arcabouço teórico proposto por Dixit e Londregan (1996) e Dixit e Londregan (1998), entre outros, uma visão alternativa das transferências governamentais argumenta que a movimentação de tais recursos não seria determinada apenas por tais critérios normativos, mas também por interesses oportunistas. Neste sentido, instâncias superiores de governo poderiam fazer uso desses recursos de forma a angariar suporte político junto às localidades beneficiadas ou então, governantes de instâncias locais poderiam explorar esse mecanismo de forma a angariar recursos em níveis superiores de governo de modo a ampliar sua força política em sua região. Assim, o alinhamento partidário entre níveis distintos de governo seria um deter- 
minante importante das transferências fiscais, tais que localidades alinhadas com níveis superiores de governo seriam beneficiadas com maiores repasses.

A literatura internacional que trata dos determinantes políticos das transferências recebidas por unidades locais a partir de instâncias superiores de governo apresenta resultados empíricos importantes, como o trabalho de Cox e McCubbins (1993), por exemplo, que apresenta algumas das primeiras evidências de que o alinhamento partidário entre níveis distintos de governo de fato influencia o comportamento das transferências fiscais. Para os Estados Unidos, Grossman (1994) avalia uma amostra de estados americanos contemplando anos de 1974, 1977, 1980 e 1983 e encontra evidências de que estas instâncias recebem maiores transferências do governo federal quando o chefe do executivo é alinhado com o partido majoritário no congresso federal. Ao analisar as transferências referentes a programas assistenciais recebidos pelos distritos americanos a partir do governo federal entre 1984 e 1990, os resultados obtidos por Levitt e Snyder-Jr. (1995) contrariam esta ideia, ou seja, as transferências parecem não ser influenciadas pelo alinhamento partidário. Mais recentemente, em uma nova análise para os estados americanos, os resultados obtidos por Larcinese, Rizzo e Testa (2006) corroboram a percepção de que o alinhamento partidário entre o presidente e os governadores influencia positivamente o recebimento dos recursos federais.

Para o caso indiano, por sua vez, Khemani (2007) investiga um painel de estados entre os anos de 1972 e 1995 e encontra evidências de que transferências discricionárias são fortemente influenciadas pelo alinhamento partidário com o governo central. Pelo contrario, as transferências constitucionais, que são administradas por uma agência independente, tendem a ser menores caso ocorra o alinhamento partidário. No total das duas transferências, o efeito do alinhamento é nulo. Também avaliando um painel de estados indianos entre 1974 e 1997, Arulampalam et al. (2009) encontra resultados que indicam que o alinhamento com o governo central também eleva o montante de recursos recebidos pelos mesmos.

Ainda em relação à literatura internacional, Rozevitch e Weiss (1993) avalia uma amostra de municípios israelenses entre os anos 60 e 80 e encontra evidências de que o alinhamento partidário entre o governo local e o parlamento tende a elevar os recursos recebidos. Resultados semelhantes são obtidos por Porto e Sanguinetti (2001) que, ao analisar uma amostra de províncias argentinas entre as décadas de 1960 e 1990, encontram evidências de que as transferências recebidas estão positivamente associadas a maiores níveis de representação na câmara federal e no senado. São também semelhantes aos resultados obtidos por Veiga e Pinho (2007), segundo os quais em anos de eleições municipais e em anos de eleição para o legislativo federal, o alinhamento dos governos municipais portugueses com o governo central amplia as transferências recebidas. O efeito positivo do alinhamento sobre as transferências fiscais é corroborados por outro estudo mais recente também referente aos municípios portugueses realizado por Migueis $(2013)^{3}$.

3 Em uma perspectiva alternativa, o recente estudo de Herwartz e Theilen (2012) procura investigar se o esforço fiscal dos estados alemães (mensurado como uma maior arrecadação própria) é maior caso seus chefes de governo sejam politicamente alinhados com o governo federal. As evidências obtidas pelos autores não permitem corroborar tal hipótese. Johansson (2003), por sua vez, analisa um painel de municípios suecos entre 1981 e 1995 e encontra evidências de que as transferências recebidas a partir do governo estadual tendem a ser maiores quanto maior a proporção de swing voters. 
Ainda que as transferências fiscais sejam bastante significativas no Brasil, a literatura que versa sobre este tema não é tão vasta. Um dos poucos estudos que abordam as transferências recebidas pelos municípios brasileiros é o trabalho de Mendes (2005), cujos resultados sugerem que os gastos locais com o poder legislativo crescem de forma mais que proporcional conforme crescem os recursos recebidos via transferências federais (via Fundo de Participação de Municípios (FPM), em particular) e estaduais (via cota-parte do ICMS, em particular), reforçando a ideia de "captura" dos recursos por parte da burocracia local. Alguns anos depois, Ferreira e Bugarin (2007) encontram evidências de que o alinhamento partidário dos prefeitos brasileiros com o governo central ou então, com seus respectivos governos estaduais, tende a elevar o volume recebido de transferências fiscais. A partir desta evidência, os autores reconstituem o trabalho seminal de Rogoff (1990) e concluem que, no caso brasileiro, as transferências governamentais podem desempenhar um papel forte o suficiente para que o eleitor prefira eleger um governante incompetente, mas politicamente alinhado com instâncias superiores do poder político (o que garantiria maior acesso aos seus recursos públicos) do que eleger um governante competente, mas não alinhado.

Ainda nessa mesma linha, Duchateau e Aguirre (2010) analisam as transferências recebidas pelos governos estaduais brasileiros entre 1999 e 2003 e encontram evidencias de que possuir governadores alinhados (em termos partidários) com o Presidente da República e com senadores pertencentes aos partidos da base governista favorece os governos estaduais na obtenção de recursos federais, seja via transferências voluntárias, seja via despesas de investimento. Finalmente, o recente trabalho de Brollo e Nannicini (2012), utilizando o método de regressão descontínua, encontra evidências de que os municípios brasileiros recebem mais transferências federais quando o chefe do poder executivo local é filiado a um partido da coalizão do Presidente da República. Segundo os autores, esse efeito é impulsionado principalmente pelo fato de que o governo federal penaliza municípios administrados por prefeitos da oposição que venceram por uma margem estreita de votos, buscando assim, reduzir suas chances de vitória na próxima eleição.

Conforme mencionado anteriormente, o artigo a ser considerado como referência para o estudo aqui proposto é o desenvolvido por Sole-Olle e Sorribas-Navarro (2008), no qual os autores procuram investigar como o montante de transferências recebidas pelos governos locais é influenciado pelo alinhamento partidário com instâncias superiores do poder político. Mais especificamente, os autores consideram uma amostra com quase 900 municípios espanhóis entre os anos de 1993 a 2003 e levam em conta a existência de três níveis de governo superiores aos municípios para estudar o efeito do alinhamento partidário. A exemplo do Brasil, os dois primeiros são o governo central e o governo estadual, mas no caso espanhol, há também uma terceira instância, situada entre o governo estadual e o município, denominada Disputación. Os resultados obtidos sugerem que o alinhamento ideológico com níveis superiores de fato afeta, e de forma positiva, o montante de transferências recebidas pelas unidades locais espanholas. Dado a importância do método de estimação proposto por Sole-Olle e Sorribas-Navarro (2008), a próxima seção deste capítulo tem como objetivo detalhá-lo. 


\subsection{Procedimentos metodológicos}

Tendo como referência o estudo de Sole-Olle e Sorribas-Navarro (2008), as transferências g recebidas por um município i em um dado instante t, a partir do governo federal (F) e a partir de seu respectivo governo estadual (E), podem ser formalizadas da seguinte forma (omitindo as variáveis de controle, para facilitar a interpretação):

$$
\begin{aligned}
& g_{i t}^{F}=c_{i}^{F}+\beta_{1} \cdot a_{i t}^{F}+\epsilon_{i t}^{F} \\
& g_{i t}^{E}=c_{i}^{E}+\beta_{1} \cdot a_{i t}^{E}+\epsilon_{i t}^{E}
\end{aligned}
$$

Nessas equações, $g_{i t}^{l}$ representa o montante de transferências recebidas por um município i, em um dado período t, a partir do governo federal (se $1=\mathrm{F}$ ) ou então do seu respectivo governo estadual (se $1=\mathrm{E}$ ). Em sequência, $c_{i}^{l}$ representa o efeito fixo do município associado aos recursos recebidos do nível de governo l e a variável $a_{i t}^{l}$ vem a ser uma dummy indicadora do alinhamento partidário do município i, em um período t, com o nível de governo l. Finalmente, $\epsilon_{i t}^{l}$ definem os termos de erro para cada uma das duas equações de transferências.

De acordo com o trabalho supramencionado, o procedimento Cross Section (CS), considera apenas a variação entre municípios quanto aos recursos recebidos a partir do governo federal e do governo estadual, separadamente. Posto de outra forma, este procedimento considera a variação existente entre municípios alinhados e não-alinhados com um dado nível superior de governo, em um determinado período. Esta seria a alternativa natural para aqueles estudos cuja amostra seja um corte longitudinal simples, sem a possibilidade de se avaliar qualquer diferença ao longo do tempo (como o trabalho de Grossman (1994), por exemplo). Exemplificando-se com o caso do alinhamento com o governo estadual $(1=\mathrm{E})$, ter-se-ia a seguinte equação, em que $\eta_{i}^{E}=c_{i}^{E}+\epsilon_{i}^{E}$ :

$$
g_{i}^{E}=\beta_{1} \cdot a_{i}^{E}+\eta_{i}^{E}
$$

A estimação da Equação (3) geraria uma estimativa não-enviesada e consistente do efeito do alinhamento sobre as transferências somente se o termo de erro $\epsilon_{i}^{E}$ fosse não correlacionado o alinhamento. Contudo, isto pode não ser válido dado que neste caso, a dummy de alinhamento também estaria captando fatores como diferenças nas preferências dos partidos, entre outros ${ }^{4}$, de tal forma que as estimações obtidas por meio deste método seriam enviesadas e inconsistentes. Já o segundo procedimento, denominado pelos autores Time Differences (Time D), considera as variações no alinhamento que ocorrem ao longo do tempo, para um dado município. Novamente, exemplificando com o caso do alinhamento com o governo estadual e utilizando o símbolo $\Delta$ para fazer menção à diferença no tempo, valeria a seguinte notação:

$$
\Delta g_{i t}^{E}=\beta_{1} . \Delta a_{i t}^{E}+\Delta \epsilon_{i t}^{E}
$$

4 As transferências poderiam ser maiores não por causa do alinhamento em si, mas porque alguns partidos poderiam fazer maior uso das transferências do que outros, por exemplo. 
Apesar deste procedimento controlar as estimações pelo efeito fixo via diferença no tempo, o alinhamento do município com o governo estadual e com o governo federal seriam tratadas separadamente. Ademais, a depender da amostra, o efeito da variação seria decorrente apenas de variações em um dado nível de governo (variação intra-município, por exemplo).

O terceiro procedimento sugerido pelos autores, denominado Grantor Differences (Grantor D), considera as variações do alinhamento municipal com diferentes níveis superiores de governo, em um dado período de tempo. Neste caso, seria válida a seguinte notação, sendo $\eta_{i}^{F E}=\left(c_{i}^{F}-c_{i}^{E}\right)+\left(\epsilon_{i}^{F}-\epsilon_{i}^{E}\right)$ :

$$
g_{i}^{F}-g_{i}^{E}=\beta_{1} \cdot\left(a_{i}^{F}-a_{i}^{E}\right)+\eta_{i}^{F E}
$$

Nota-se que esse procedimento explora a variação que decorre da possibilidade de um município estar alinhado com um nível superior de governo (estadual, por exemplo) e não estar com o outro (federal). Contudo, nota-se que este procedimento sofre de restrição semelhante ao procedimento CS, pois por ser uma cross section, não controla as estimações pelo efeito fixo.

Finalmente, o quarto e último procedimento considerado pelos autores é denominado Triple Differences (Triple D), que considera informações em painel sobre transferências recebidas por uma dada localidade tanto por instâncias superiores distintas como também em períodos sucessivos de governo. Neste caso, a equação a ser estimada assumiria a seguinte forma:

$$
\Delta g_{i}^{F}-\Delta g_{i}^{E}=\beta_{1} \cdot\left(\Delta a_{i}^{F}-\Delta a_{i}^{E}\right)+\Delta \epsilon_{i}^{F E}
$$

Nota-se que este método considera todas as três variações existentes (entre municípios, entre períodos e entre níveis de governo), ou seja, permite lidar com as restrições que incidem sobre os métodos anteriores. A derivação deste último procedimento é a principal contribuição metodológica de Sole-Olle e Sorribas-Navarro (2008), e o objetivo deste artigo é adotá-lo para o caso brasileiro, apresentando os resultados dos demais métodos para comparação dos resultados. Note que este procedimento é especialmente válido para o caso brasileiro, dado que explora as transferências originárias tanto do governo federal como do governo estadual. Os recentes trabalhos de Brollo e Nannicini (2012) e Gadenne (2015), por exemplo, consideram as transferências do governo federal, mas ignoram o papel exercido pelas transferências estaduais. Como é bem sabido, ainda que o repasse desses recursos (aos municípios) varie entre os estados, especialmente em função das próprias diferenças existentes nos critérios de arrecadação e de repasse, sua importância é significativa e não deve ser, portanto, desprezada. A título de ilustração, no ano de 2008, as receitas de transferências estaduais representaram apenas $2 \%$ e $8 \%$ da receita orçamentária de Coroatá (MA) e Piripiri (PI), respectivamente, mas representaram $22 \%$ em Pedro Leopoldo (MG), 29\% em São Gabriel (RS) e 33\% em Penápolis (SP), municípios todos com aproximadamente 60 mil habitantes.

A partir das informações disponibilizadas pela Secretaria do Tesouro Nacional (STN), é possível desmembrar as transferências recebidas pelos municípios brasileiros a 
partir do governo federal e a partir de seus respectivos governos estaduais. O nível de detalhamento das informações referentes às transferências varia entre os anos de 1999 a 2012 (período amostral analisado no trabalho), mas em termos simplificados, é possível decompor tais recursos entre transferências correntes e de capital, e entre recursos repassados pelo governo federal ou pelo governo estadual ${ }^{5}$.

As transferências correntes, especialmente aquelas oriundas do governo federal, contemplam as transferências constitucionais, para as quais existem critérios pré-definidos de distribuição. Esse é o exemplo típico do FPM, por exemplo, que leva em conta critérios como renda per capita e porte populacional, entre outros. Para as transferências correntes oriundas dos governos estaduais, raciocínio semelhante também pode ser considerado, como ocorre com os recursos referentes à cota-parte do $\mathrm{IPVA}^{6}$ e do $\mathrm{ICMS}^{7}$, por exemplo, que também são distribuídos aos municípios por meio de critérios definidos de antemão. Desta forma, é pouco provável que esses recursos estejam sujeitos à influência do alinhamento partidário ou ideológico. Contudo, dentro das transferências correntes, existem os valores referentes às chamadas "Outras transferências correntes da União" e "Outras transferências correntes do estado", valores não definidos pelos critérios anteriormente estabelecidos e que podem refletir mais adequadamente o efeito de critérios discricionários para a sua distribuição, em especial, o alinhamento partidário. São justamente essas as categorias de transferências governamentais que serão analisadas neste artigo, sendo essas as mesmas categorias analisadas por Ferreira e Bugarin (2007). Além desses recursos, este trabalho analisará também outro canal importante de transferência de recursos do governo federal e dos governos estaduais aos municípios brasileiros, qual seja, as Transferências de capital, definidas como dotações para investimentos ou inversões financeiras por parte dos municípios. Dado que o repasse desses recursos também não é definido por critérios pré-estabelecidos, existe possibilidade de discricionariedade na transferência dos mesmos e consequentemente, margem para que o alinhamento partidário influencie o montante recebido pelos municípios do país.

As variáveis de controle, baseadas no modelo teórico proposto por Sole-Olle e Sorribas-Navarro (2008), se dividem em dois grupos: o primeiro, de natureza política, é composto pela fragmentação de votos ao executivo nas eleições locais, calculada para cada município e para cada mandato local ${ }^{8}$ com base na fórmula Fragmentação de votos $=1-\sum_{j=1}^{J} v_{j}^{2}$, em que $v_{j}$ é a proporção de votos $\left(0<v_{j}<1\right)$ obtida por cada candidato $\mathrm{j}$ a prefeito, em cada eleição municipal. Esta medida, inicialmente proposta por Rae (1971) e também discutida nos trabalhos de Rae (1995), Santos (2004), Nicolau (2005) e Dutta (2009), entre outros, aumenta conforme a distribuição de votos entre os candidatos se torna mais homogênea. Tal indicador, que mensura o grau de competição política na eleição local, atua como proxy para heterogeneidade da preferência dos eleitores de uma dada localidade ${ }^{9}$

5 Não é possível analisar os dados anteriores ao ano de 1999 em função do menor detalhamento das transferências.

6 Imposto sobre a propriedade de veículos automotores.

7 Imposto sobre operações relativas à circulação de mercadorias e sobre prestações de serviços de transporte interestadual, intermunicipal e de comunicação.

8 Assim, para cada município, este indicador varia entre mandatos, mas é constante entre os anos de um dado mandato municipal.

9 Uma medida bastante utilizada em Ciência Política e o chamado "Número efetivo de candidatos", ini- 
Por sua vez, o segundo grupo de variáveis de controle é composto por indicadores demográficos, quais sejam, a população total ${ }^{10}$, a porcentagem de jovens ${ }^{11}$ e o grau de urbanização $^{12}$, que procuram mensurar o grau de necessidade de recursos públicos por uma determinada localidade. Essas variáveis, cuja inclusão é inspirada nos trabalhos de Grossman (1994), Levitt e Snyder-Jr. (1995), Johansson (2003), Sole-Olle e SorribasNavarro (2008) e Arulampalam et al. (2009), entre outros, foram construídas com base nos dados obtidos junto ao Instituto Brasileiro de Geografia e Estatística (IBGE) e em todas as estimações, foram inseridas em nível ${ }^{13}$. Por fim, as informações referentes aos prefeitos dos municípios brasileiros foram obtidas junto ao Tribunal Superior Eleitoral (TSE). Ressalta-se que os valores referentes às transferências foram deflacionados por meio do Índice de Preços ao Consumidor Amplo (IPCA) e estão mensurados em R\$ de 2014 .

Ainda em relação à metodologia adotada no artigo, é importante esclarecer os seguintes pontos:

1. Classificação das Outras transferências correntes:

O primeiro ponto importante se refere ao fato do Tesouro Nacional definir uma classificação (desagregação) das Outras transferências correntes que sofre alterações ao longo do período amostral analisado no trabalho, o que limita a realização de comparações entre-anos para toda a amostra. Já para as Transferências de capital, a metodologia é sempre a mesma, o que permite considerar todos os anos da amostra sem maiores restrições;

2. Calendário eleitoral:

No Brasil, as eleições municipais são realizadas de forma escalonada com as eleições estaduais e federais. Em função disto, um prefeito que seja politicamente alinhado com o governo federal em seus dois primeiros anos de mandato pode não mais sê-lo nos seus dois últimos anos caso haja troca de partido do Presidente da República durante o mandato local - o mesmo raciocínio vale para o alinhamento do município com seu respectivo governo estadual. Dado que a amostra aqui utilizada contempla várias eleições locais e estaduais/federais, tem-se que o alinhamento pode variar dentro de um mandato municipal fixo (em função da ocorrência da eleição estadual e federal durante o período) ou então, dentro de um mandato estadual/federal fixo (em função da ocorrência da eleição municipal durante o período), assegurando-se maior variação (no tempo) do regressor de interesse e, portanto, maior possibilidade de se identificar o efeito do alinhamento. Durante o período amostral tratado nos trabalhos de Grossman (1994) e Khemani (2007), por exemplo, não houve alteração no controle do governo central. Restrição semelhante é observada no trabalho

cialmente proposto por Laakso e Taagepera (1979) e definido por meio da fórmula $1 / \sum_{j=1}^{J} v_{j}^{2}$. Apesar da diferença no método de cálculo, a intuição é relativamente semelhante ao índice de fragmentação de votos, uma vez que quanto maior seu valor, mais acirrada a disputa eleitoral.

10 Em logaritmo natural, para tornar os valores menos heterogêneos.

11 Porcentagem da população municipal com idade entre 0 e 14 anos.

12 Porcentagem da população municipal residente em áreas urbanas.

13 Caso contrário, não seria possível considerar o efeito dessas variáveis nos procedimentos Grantor D e Triple D. 
de Levitt e Snyder-Jr. (1995) que, ao estimar cross sections, não leva em conta a variação do alinhamento no tempo.

3. O conceito de alinhamento:

Este trabalho define como alinhado um prefeito cujo partido foi membro da coligação que elegeu o governador estadual (no caso do alinhamento com o governo estadual) ou então, um prefeito cujo partido foi membro da coligação que elegeu o Presidente da República (no caso do alinhamento com o governo federal). Adotou-se tal alternativa uma vez que o alinhamento puro entre partido do prefeito $\mathrm{x}$ partido do governador e partido do prefeito $\mathrm{x}$ partido do presidente seria uma medida muito restritiva de alinhamento, o que poderia limitar os resultados obtidos. Nas extensões deste estudo, utiliza-se uma medida alternativa de alinhamento com o governo federal, que considera, além dos partidos que fizeram parte da coligação que elegeu o Presidente da República, os partidos que ocuparam algum ministério, conforme será discutido na sequência deste trabalho.

Com vistas a ilustrar os pontos (1) e (2) mencionados anteriormente, a Tabela 1 apresenta os anos contemplados na amostra (1999 a 2012), com a definição dos anos eleitorais em que os governantes foram eleitos. Além disso, apresentam-se também os períodos em que há variação no alinhamento partidário município x governo estadual e município x governo federal, que são justamente as variações que permitem identificar o efeito de interesse. Finalmente, apresentam-se também os períodos em que variam as metodologias de registro das Outras transferências correntes ${ }^{14}$. Com base nesta ilustração, note, por exemplo, que entre 2000 e 2001 há variação no alinhamento (em função da variação nos governos municipais) e a metodologia das Outras transferências correntes é a mesma (metodologia A), o que permite realizar a estimação em primeira diferença (casos dos procedimentos Time $D$ e Triple $D$ ). O mesmo é válido para a variação entre 2002 e 2003 (metodologia B), embora aqui, a variação do alinhamento decorra da variação nos governos estaduais e federal. Desta forma, no caso das Outras transferências correntes, é necessário trabalhar com pares separados de anos para evitar o problema de se comparar valores registrados com base em metodologias distintas.

Conforme mencionado anteriormente, o período amostral contemplado neste estudo compreende os anos de 1999 a 2012. Entre todos os municípios do país, alguns foram retirados por não terem informações para alguns anos, fazendo com que a amostra seja um painel balanceado de 3.345 municípios - a opção do painel balanceado decorre do fato de alguns procedimentos envolverem primeira-diferença, o que requer que a amostra apresente tal característica.

As figuras apresentadas em sequência ilustram o comportamento das principais variáveis de interesse deste trabalho. A Figura 1 mostra que a proporção de municípios politicamente alinhados com o governo federal variou entre $33 \%$ e $51 \%$ entre 1999 e 2012, ao passo que o alinhamento com o governo estadual parece ser mais instável: os valores oscilam em torno de $42 \%$ até 2002, passam a oscilar entre 8,5\% e $15 \%$ entre 2003 e 2010, e

14 Note que a classificação das metodologias A até F serve apenas para ilustrar as variações existentes no registro das Outras transferências correntes, ou seja, não tem o objetivo de detalhar com maior rigor quais são essas diferenças especificamente. 


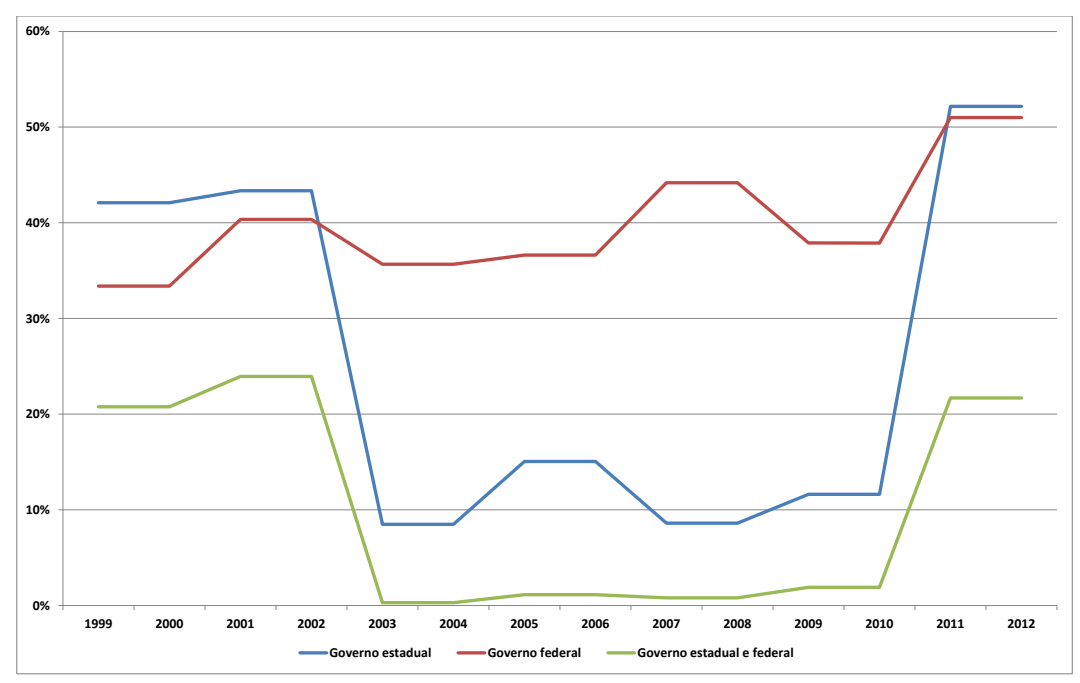

Figura 1 - Porcentagem de municípios alinhados com o governo federal e/ou estadual Fonte: elaboração própria

entre 2011 e 2012 sofrem significativa elevação, atingindo valores superiores a $50 \%$. Entre 1999 e 2002 e entre 2011 e 2012, aproximadamente 22\% dos municípios eram alinhados com os dois níveis superiores de governo, mas entre 2003 e 2010, estes valores atingiram no máximo $2 \%$.

As Figuras 2(a) e 2(b) apresentam, respectivamente, os valores médios referentes às Outras transferências correntes (por habitante) provenientes do governo federal e estadual, separadas entre municípios alinhados e não alinhados. As duas figuras indicam uma queda dos valores até 2003 sem ser possível notar uma diferença significativa entre municípios alinhados e não alinhados. A partir de então, nota-se uma estabilização dos valores na casa de $\mathrm{R} \$ 14$ por habitante no caso do alinhamento com o governo federal (com um forte aumento no ano de 2009), sem ser possível notar uma diferença significativa entre alinhados e não alinhados, e uma estabilização em torno de $\mathrm{R} \$ 5,70$ por habitante no caso do alinhamento com o governo estadual, sendo possível notar uma discreta superioridade para os municípios alinhados. Contudo, essas comparações devem ser vistas com cautela dado que são médias simples e dada a mudança de metodologia de registro deste tipo de transferência.

No caso das Transferências de capital (Figuras 3(a) e 3(b)), nota-se também uma queda dos valores até 2003 e uma discreta tendência de crescimento a partir de então. Apesar deste comportamento, as figuras indicam uma diferença mais perceptível entre municípios alinhados e não alinhados, especialmente caso o município seja alinhado com o governo estadual - em 2008, por exemplo, o primeiro grupo recebeu quase $\mathrm{R} \$ 16$ por habitante, ao passo que o segundo recebeu aproximadamente $\mathrm{R} \$ 7$ por habitante. 


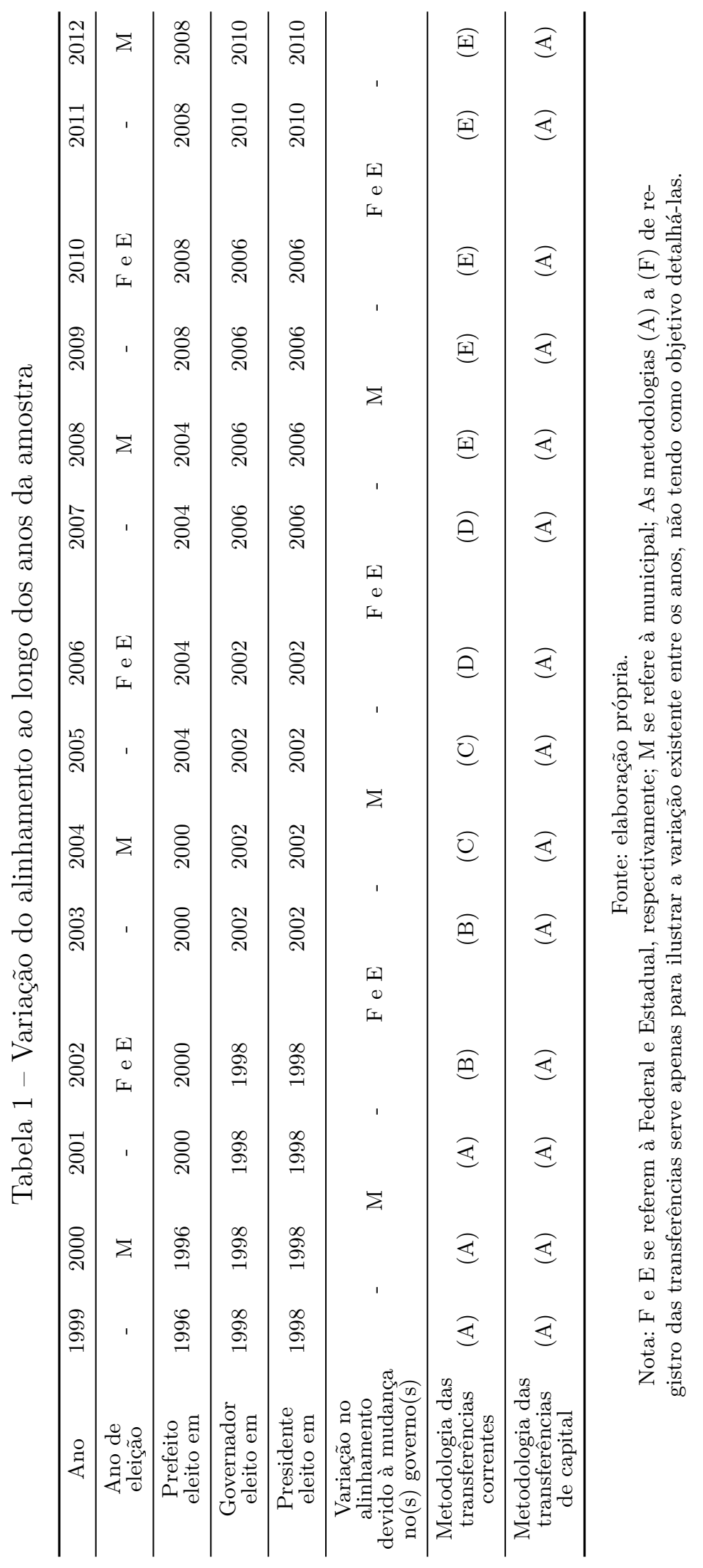




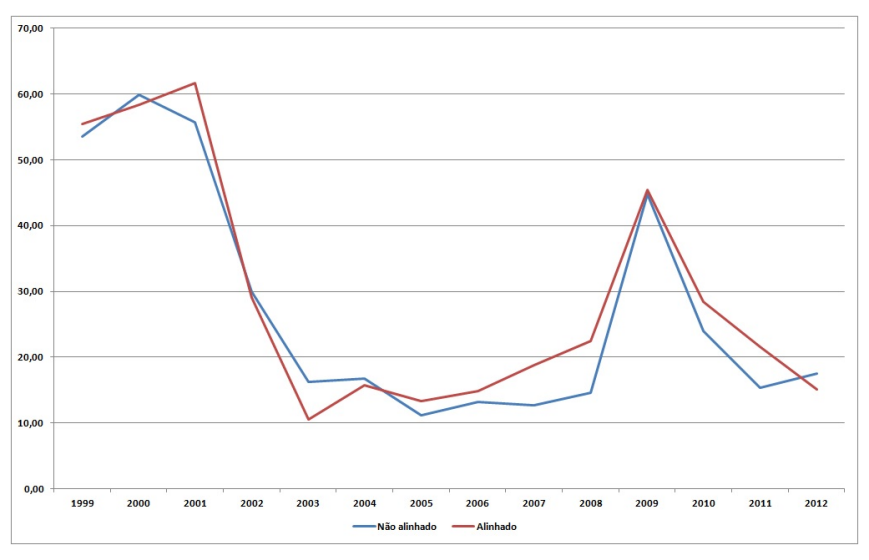

(a) Governo federal

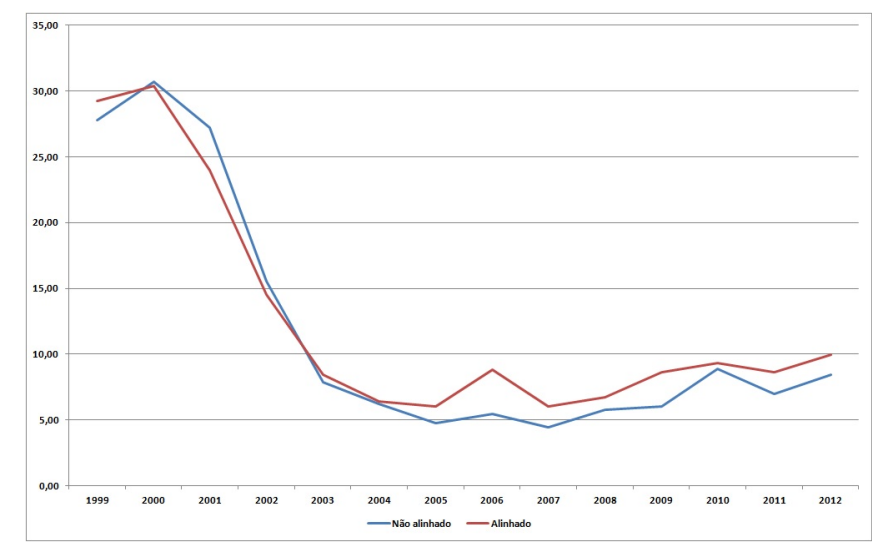

(b) Governo estadual

Figura 2 - Outras transferências correntes

Fonte: elaboração própria

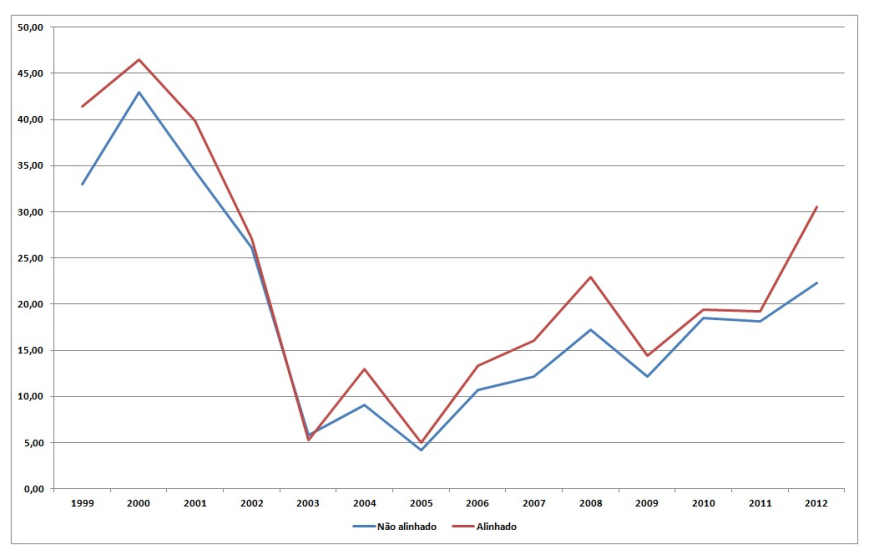

(a) Governo federal

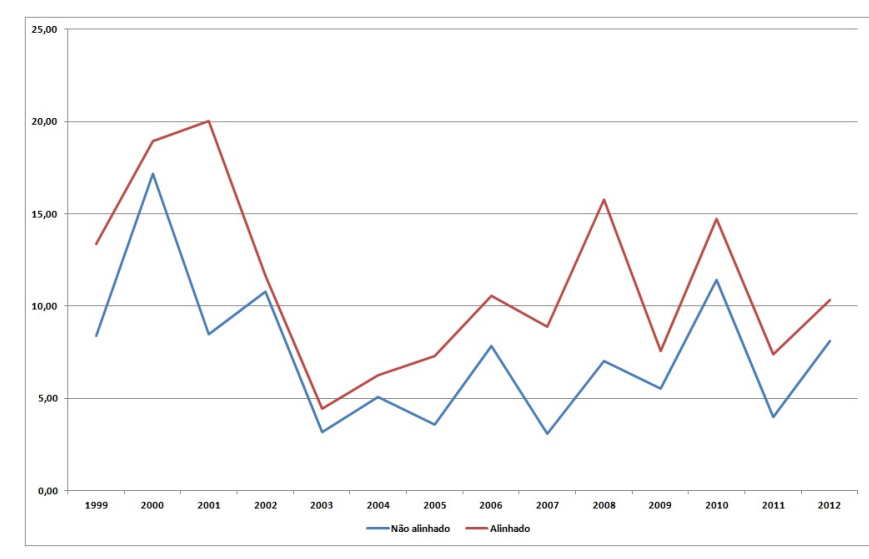

(b) Governo estadual

Figura 3 - Transferências de capital 


\subsection{Resultados}

Esta seção do capítulo apresenta os resultados das estimações, divididos em duas subseções: a primeira discute os resultados referentes às Outras transferências correntes, ao passo que a segunda discute as Transferências de capital. Os valores reportados entre colchetes nas Tabelas se referem ao erro-padrão dos coeficientes ${ }^{15}$, ao passo que asteriscos denotam significância estatística a ${ }^{*}=10 \%,{ }^{* *}=5 \% \mathrm{e}^{* * *}=1 \%$, respectivamente.

\subsubsection{Outras transferências correntes}

Conforme discutido anteriormente, existe variação da classificação da rubrica Outras transferências correntes ao longo do tempo, conforme ilustrado na Tabela 1. Este fato não representa nenhum problema mais grave para os procedimentos Cross Section e Grantor $D$, dado que ambos consideram apenas as variações entre municípios, em um dado período (com a ressalva de que os resultados de cada ano não podem ser comparados entre si, neste caso). Contudo, nos procedimentos que envolvem diferença no tempo (caso dos procedimentos Time $D$ e Triple $D$ ), a diferença de classificação passa a ser relevante. Apesar desta restrição, ainda é possível realizar os procedimentos Time $D$ e Triple $D$ para os pares de ano 2000 x 2001, 2002 x 2003, 2004 x 2005, 2006 x 2007, 2008 x 2009 e 2010 x 2011, dado que existe variação de alinhamento entre os anos de cada um destes pares e a metodologia de registro dos valores permanece a mesma.

Os primeiros resultados, referentes ao procedimento Cross Section, são apresentados na Tabela 2. Em relação às transferências do governo federal (Painel A), nota-se que praticamente todos os parâmetros associados ao alinhamento não apresentam significância estatística aos níveis usualmente considerados sugerindo, portanto, que municípios cujo prefeito seja membro de algum partido da coligação do Presidente da República não recebem montante superior desses recursos. A exceção fica por conta do ano de 2011, para o qual os resultados indicam que prefeituras alinhadas com o governo federal recebem $\mathrm{R} \$$ 7,34 por habitante a mais comparativamente à prefeituras não alinhadas.

A fragmentação de votos para o executivo local, que atua como proxy para a heterogeneidade da preferência dos eleitores, é significante apenas em 2004 e 2006, assumindo valor positivo e negativo, respectivamente. Isto impossibilita definir com maior exatidão o efeito desta variável sobre os repasses do governo federal. Finalmente, em relação às variáveis demográficas, nota-se que os efeitos da proporção de jovens e da urbanização, quando estatisticamente significantes, assumem valores positivos. O único efeito sistemático é o referente ao tamanho da população, que afeta negativamente os valores recebidos por habitante.

No caso das transferências estaduais (Painel B), os resultados para os anos de 1999, 2000, 2006, 2007, 2009, 2011 e 2012 foram positivos e estatisticamente significantes - no último destes anos, por exemplo, o alinhamento com os governos estaduais significou um montante de recursos $\mathrm{R} \$ 1,59$ maior por habitante comparativamente aos municípios não alinhados. Em relação à fragmentação de votos para o executivo local, por sua vez, tem-se um coeficiente estatisticamente significante somente no ano de 2005 , indicando um

$\overline{15}$ Nos procedimentos Time D e Triple D, os erros-padrão foram calculados via agrupamento (clustering) por município. 
efeito negativo sobre os recursos recebidos dos governos estaduais. Assim, a exemplo das Outras transferências correntes do governo federal, o efeito deste regressor sobre as Outras transferências correntes do governo estadual parece não ser sistemático. Já em relação As variáveis demográficas, observa-se que o efeito da proporção de jovens e do tamanho da população é negativo e estatisticamente significante na maioria dos anos. Por fim, o efeito da taxa de urbanização é significativo somente em alguns anos específicos, sendo positivo nestes casos específicos.

No caso do procedimento Time $D$ (Tabela 3), os resultados indicam que a variação entre-anos do alinhamento partidário governo municipal x governo federal continua exercendo pouco efeito sobre o montante de transferências recebidas. As regressões apresentam coeficientes estatisticamente nulos para a dummy de alinhamento à exceção da estimação referente período 2008-2011 ${ }^{16}$. A exemplo do procedimento Cross-Section, o efeito da fragmentação de votos parece não ser robusto, ao passo que as variáveis demográficas exibem, em geral, efeito estatisticamente nulo sobre as transferências. Já no caso do alinhamento com o governo estadual, observa-se coeficiente positivo e significante somente entre os anos de 2000 e 2001, o qual sugere aumento da ordem de $R \$ 3,86$ por habitante quando um município passa a ser alinhado com seu governo estadual. A fragmentação de votos, a exemplo das transferências do governo federal, parece não exercer influência robusta sobre os recursos recebidos, assim como parece ser discreto o efeito das variáveis demográficas - apenas o efeito da população é mais sistemático entre as estimações, dado que os parâmetros exibem, em geral, significância estatística e sinal positivo, indicando portanto aumento das transferências estaduais conforme aumente o porte populacional ${ }^{17}$.

Passando a discutir os resultados do procedimento Grantor D, apresentados na Tabela 4, os coeficientes referentes ao alinhamento não apresentam significância estatística nos níveis usualmente considerados na maioria das estimações. As exceções ficam por conta do ano 2000, cujo parâmetro negativo indica que a diferença de alinhamento diminui as transferências em aproximadamente $\mathrm{R} \$ 4,66$ por habitante, e para o ano 2006, quando a diferença de alinhamento passa a afetar positivamente o montante recebido em $\mathrm{R} \$ 2,12$ por habitante. Quanto à fragmentação de votos para o executivo local, são observados coeficientes estatisticamente nulos para a maioria dos casos. Por fim, quanto às variáveis demográficas, os resultados sugerem que o efeito da proporção de jovens, positivo e estatisticamente significativo nos primeiros anos da amostra, deixa de sê-lo a partir de 2006. Já a população, que nos anos iniciais da amostra não exerce efeito robusto sobre as transferências correntes, passa a exercer efeito negativo e estatisticamente significante em todos os anos a partir de 2007.

Finalmente, a Tabela 5 apresenta os resultados obtidos de acordo com o procedimento Triple $D$, que contempla as variações entre municípios, entre anos e entre níveis de governo. A exceção dos anos entre 2008 e 2011, para os quais é observado um efeito negativo do alinhamento sobre as transferências, observa-se novamente que o coeficiente associado ao alinhamento partidário não apresenta significância estatística, ou seja, a va-

16 Cujo valor negativo sugere queda das transferências caso a localidade passe a ser gerida por um prefeito alinhado ao governo federal.

17 O fato do efeito do tamanho da população ser positivo neste procedimento e negativo no procedimento Cross Section não deve ser visto como contraditório dado que os procedimentos exploram fontes diferentes de variação. 


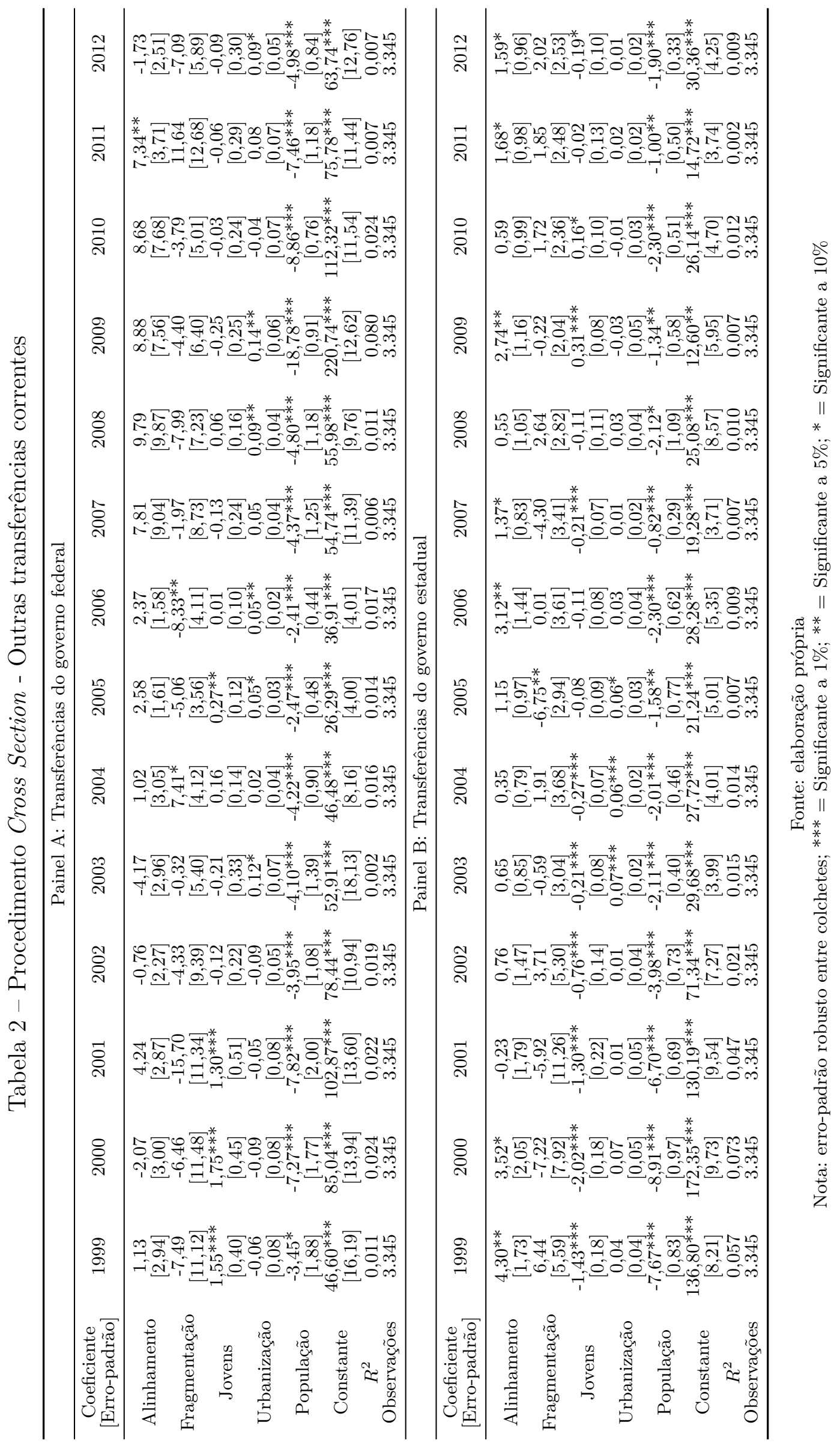


Tabela 3 - Procedimento Time D - Outras transferências correntes

\begin{tabular}{|c|c|c|c|c|c|}
\hline \multicolumn{6}{|c|}{ Painel A: Transferências do governo federal } \\
\hline $\begin{array}{c}\text { Coeficiente } \\
{[\text { Erro-padrão] }}\end{array}$ & $2000-2001$ & $2002-2003$ & 2004-2005 & $2006-2007$ & 2008-2011 \\
\hline \multirow{2}{*}{ Alinhamento } & 1,31 & $-0,67$ & 1,21 & 4,84 & $-14,15^{* * *}$ \\
\hline & {$[2,65]$} & {$[2,89]$} & {$[1,50]$} & {$[3,46]$} & {$[2,47]$} \\
\hline \multirow{2}{*}{ Fragmentação } & 3,74 & 3,52 & $-5,91$ & 6,58 & 2,49 \\
\hline & {$[12,04]$} & {$[10,57]$} & {$[4,46]$} & {$[8,88]$} & {$[7,68]$} \\
\hline \multirow{2}{*}{ Jovens } & $-0,32$ & $-0,09$ & 0,14 & $-0,13$ & 0,23 \\
\hline & {$[0,64]$} & {$[0,38]$} & {$[0,15]$} & {$[0,23]$} & {$[0,16]$} \\
\hline \multirow{2}{*}{ Urbanização } & 0,04 & $0,21 * * *$ & 0,03 & 0,01 & 0,01 \\
\hline & {$[0,10]$} & {$[0,08]$} & {$[0,04]$} & {$[0,04]$} & {$[0,05]$} \\
\hline \multirow{2}{*}{ População } & $-0,85$ & $-0,20$ & $1,60^{*}$ & $-1,88^{*}$ & $-5,40 * * *$ \\
\hline & {$[2,31]$} & {$[1,52]$} & {$[0,87]$} & {$[1,14]$} & {$[0,94]$} \\
\hline \multirow{2}{*}{ Constante } & 11,75 & $-24,87$ & $-22,79 * * *$ & 17,49 & $58,93^{* * *}$ \\
\hline & {$[15,70]$} & {$[20,00]$} & {$[8,01]$} & {$[10,99]$} & {$[8,46]$} \\
\hline$R^{2}$ & 0,010 & 0,021 & 0,041 & 0,012 & 0,013 \\
\hline Observações & 3.345 & 3.345 & 3.345 & 3.345 & 6.690 \\
\hline \multicolumn{6}{|c|}{ Painel B: Transferências do governo estadual } \\
\hline $\begin{array}{c}\text { Coeficiente } \\
{[\text { Erro-padrão] }}\end{array}$ & $2000-2001$ & $2002-2003$ & $2004-2005$ & $2006-2007$ & 2008-2011 \\
\hline \multirow{2}{*}{ Alinhamento } & $3,86^{* *}$ & $-0,65$ & $-0,81$ & 0,78 & $-0,17$ \\
\hline & {$[1,76]$} & {$[1,22]$} & {$[1,36]$} & {$[0,82]$} & {$[0,75]$} \\
\hline \multirow{2}{*}{ Fragmentação } & $-1,31$ & $-4,32$ & $-7,96^{*}$ & $-4,04$ & $-1,18$ \\
\hline & {$[7,54]$} & {$[5,29]$} & {$[4,35]$} & {$[4,71]$} & {$[2,04]$} \\
\hline \multirow{2}{*}{ Jovens } & $0,62^{* *}$ & $0,52^{* * *}$ & $0,20^{*}$ & $-0,10$ & $-0,05$ \\
\hline & {$[0,24]$} & {$[0,13]$} & {$[0,10]$} & {$[0,09]$} & {$[0,07]$} \\
\hline \multirow{2}{*}{ Urbanização } & $-0,08$ & 0,05 & 0,01 & $-0,01$ & $-0,02$ \\
\hline & {$[0,05]$} & {$[0,04]$} & {$[0,03]$} & {$[0,04]$} & {$[0,03]$} \\
\hline \multirow{2}{*}{ População } & $2,13 * *$ & $1,75^{* * *}$ & 0,28 & $1,47 * *$ & $0,94^{* *}$ \\
\hline & {$[0,88]$} & {$[0,66]$} & {$[0,78]$} & {$[0,66]$} & {$[0,44]$} \\
\hline \multirow{2}{*}{ Constante } & $-37,62^{* * *}$ & $-39,70 * * *$ & $-5,61$ & $-9,59$ & $-5,49^{*}$ \\
\hline & {$[10,13]$} & {$[6,75]$} & {$[5,18]$} & {$[6,16]$} & {$[3,11]$} \\
\hline$R^{2}$ & 0,081 & 0,092 & 0,021 & 0,023 & 0,016 \\
\hline Observações & 3.345 & 3.345 & 3.345 & 3.345 & 6.690 \\
\hline
\end{tabular}

Fonte: elaboração própria

Nota: erro-padrão robusto entre colchetes; $* * *=$ Significante a $1 \% ; * *=$ Significante a $5 \%{ }^{*}=$ Significante a $10 \%$

riação do alinhamento prefeitura x governo federal e prefeitura x governo estadual, entre períodos consecutivos, não altera a diferença de recursos transferidos pelo governo federal relativamente aos recursos transferidos pelo governo estadual. As variáveis de controle apresentam, na maior parte das regressões, influência estatisticamente nula sobre os recursos recebidos.

\subsubsection{Transferências de capital}

Conforme mencionado anteriormente, no caso das Transferências de capital, a metodologia de classificação é a mesma ao longo do período analisado. Contudo, neste caso, existe outro fato importante também decorrente do calendário eleitoral brasileiro, dado que as eleições municipais, por um lado, e federal e estaduais, por outro, ocorrem a cada quatro anos, mas de forma escalonada, de modo que ocorrem eleições a cada dois anos, 


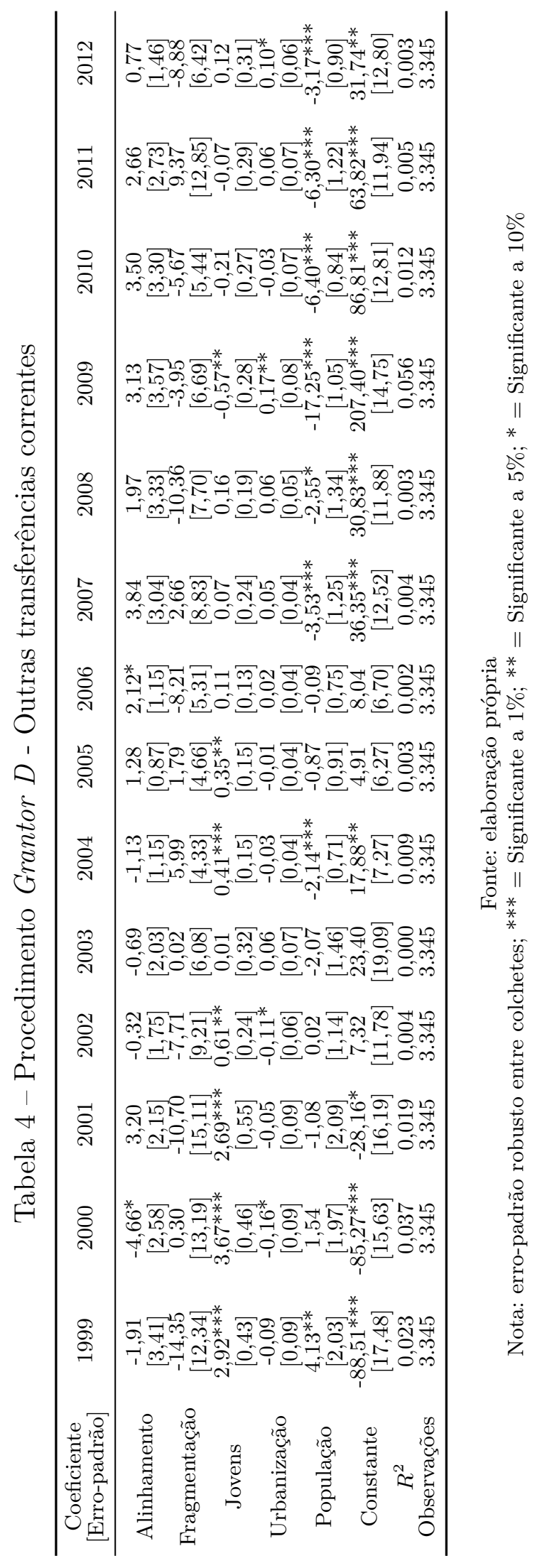


Tabela 5 - Procedimento Triple D - Outras transferências correntes

\begin{tabular}{cccccc}
\hline $\begin{array}{c}\text { Coeficiente } \\
\text { [Erro-padrão] }\end{array}$ & $2000-2001$ & $2002-2003$ & $2004-2005$ & $2006-2007$ & $2008-2011$ \\
\hline Alinhamento & $-1,04$ & $-0,67$ & $-0,55$ & 1,84 & $-3,15^{*}$ \\
& {$[2,71]$} & {$[1,44]$} & {$[1,02]$} & {$[1,16]$} & {$[1,72]$} \\
Fragmentação & 4,66 & 7,84 & 2,15 & 10,62 & 4,46 \\
& {$[13,53]$} & {$[10,52]$} & {$[6,24]$} & {$[9,59]$} & {$[7,78]$} \\
Jovens & $-0,96$ & $-0,62$ & $-0,05$ & $-0,04$ & $0,37^{* *}$ \\
& {$[0,70]$} & {$[0,38]$} & {$[0,17]$} & {$[0,25]$} & {$[0,17]$} \\
Urbanização & 0,12 & $0,15^{*}$ & 0,02 & 0,02 & 0,03 \\
& {$[0,11]$} & {$[0,08]$} & {$[0,05]$} & {$[0,06]$} & {$[0,06]$} \\
População & $-2,98$ & $-1,95$ & 1,29 & $-3,34^{* *}$ & $-6,42^{* * *}$ \\
& {$[2,51]$} & {$[1,55]$} & {$[1,14]$} & {$[1,30]$} & {$[0,99]$} \\
Constante & $50,05^{* * *}$ & 14,81 & $-17,16^{*}$ & $27,22^{* *}$ & $59,70 * * *$ \\
$R^{2}$ & {$[17,75]$} & {$[20,44]$} & {$[9,35]$} & {$[12,72]$} & {$[8,65]$} \\
Observações & 0,003 & 0,002 & 0,002 & 0,003 & 0,007 \\
& 3.345 & 3.345 & 3.345 & 3.345 & 6.690 \\
\hline
\end{tabular}

Fonte: elaboração própria
Nota: erro-padrão robusto entre colchetes; $* * *=$ Significante a $1 \% ;{ }^{* *}=$ Significante a $5 \%{ }^{*}=$ Significante a $10 \%$

conforme exposto na Tabela 1. Especificamente no caso dessas transferências, optou-se por considerar tratamento semelhante ao adotado por Sole-Olle e Sorribas-Navarro (2008), que consiste em usar a média do mandato municipal, subdividindo-o nos dois primeiros anos e nos dois últimos, de modo a diminuir a volatilidade dos valores. Assim sendo, foi considerada a média bienal dos seguintes pares de anos: 1999-2000; 2001-2002; 20032004; 2005-2006; 2007-2008; 2009-2010 e finalmente, 2011-2012. Note que esse tipo de tratamento dos dados não é aplicável às Outras transferências correntes, dado que a metodologia de registro varia entre 2001 e 2002 e entre 2003 e 2004, por exemplo. Logo, as comparações dos resultados das Outras transferências correntes com as Transferências de capital devem ser feitas com cautela.

A Tabela 6 apresenta os resultados do procedimento Cross Section. No caso das Transferências de capital do governo federal (Painel A), o coeficiente associado ao alinhamento é positivo e estatisticamente significante para a média dos biênios 1999-2000, 2005-2006, 2007-2008, 2009-2010 e 2011-2012. A título de ilustração, o resultado para o último desses biênios sugere que o alinhamento com o governo federal eleva as transferências em aproximadamente $\mathrm{R} \$ 5,88$ por habitante, comparativamente aos municípios não alinhados. Considerando que o valor médio das Transferências de capital da União foi da ordem de $\mathrm{R} \$ 21,33$ per capita neste mesmo biênio, o alinhamento com o governo federal eleva os repasses em aproximadamente 27\%, um aumento considerável. Ainda em relação às Transferências de capital do governo federal, o coeficiente associado à fragmentação de votos para prefeito é em geral negativo mas nem sempre estatisticamente significante. Já para as variáveis demográficas, nota-se que municípios de maior porte populacional tendem a receber menos transferências per capita - para os demais regressores, os parâmetros nem sempre são significantes e quando o são, seus sinais variam entre as estimações, não indicando assim um efeito robusto.

No caso das Transferências de capital do governo estadual (Painel B), os resultados sugerem que o alinhamento com o governo estadual também influencia positivamente os recursos recebidos pelos municípios brasileiro. Os resultados referentes ao biênio 2011-2012 
Tabela 6 - Procedimento Cross Section - Transferências de capital

\begin{tabular}{|c|c|c|c|c|c|c|c|}
\hline \multicolumn{8}{|c|}{ Painel A: Transferências do governo federal } \\
\hline $\begin{array}{l}\text { Coeficiente } \\
\text { [Erro-padrão] }\end{array}$ & $\begin{array}{c}\text { Média } \\
1999-2000\end{array}$ & $\begin{array}{c}\text { Média } \\
2001-2002\end{array}$ & $\begin{array}{c}\text { Média } \\
2003-2004\end{array}$ & $\begin{array}{c}\text { Média } \\
2005-2006\end{array}$ & $\begin{array}{c}\text { Média } \\
2007-2008\end{array}$ & $\begin{array}{c}\text { Média } \\
2009-2010\end{array}$ & $\begin{array}{c}\text { Média } \\
2011-2012\end{array}$ \\
\hline Alinhamento & $\begin{array}{l}5,40^{*} \\
{[3,06]}\end{array}$ & $\begin{array}{c}0,84 \\
{[2,08]}\end{array}$ & $\begin{array}{c}3,56 \\
{[2,30]}\end{array}$ & $\begin{array}{l}2,43^{*} \\
{[1,24]}\end{array}$ & $\begin{array}{c}7,15^{* * * *} \\
{[2,69]}\end{array}$ & $\begin{array}{l}4,67^{*} \\
{[2,56]}\end{array}$ & $\begin{array}{c}5,88^{* * *} \\
{[2,05]}\end{array}$ \\
\hline Fragmentação & $\begin{array}{c}{[3,00]} \\
-19,17^{*} \\
{[10,77]}\end{array}$ & $\begin{array}{c}-43,62^{* * * *} \\
{[9,93]}\end{array}$ & $\begin{array}{c}-9,29^{* *} \\
{[3,89]}\end{array}$ & $\begin{array}{l}{[1,24]} \\
0,91 \\
{[2,51]}\end{array}$ & $\begin{array}{l}{[2,99]} \\
-5,92 \\
{[7,11]}\end{array}$ & $\begin{array}{l}{[2,00]} \\
1,76 \\
{[3,84]}\end{array}$ & $\begin{array}{l}{[2,06]} \\
-2,06 \\
{[8,17]}\end{array}$ \\
\hline Jovens & $\begin{array}{c}1,73 * * * \\
{[0,64]}\end{array}$ & $\begin{array}{c}1,22 * * * \\
{[0,46]}\end{array}$ & $\begin{array}{l}-0,01 \\
{[0,11]}\end{array}$ & $\begin{array}{c}0,03 \\
{[0,15]}\end{array}$ & $\begin{array}{l}-0,07 \\
{[0,18]}\end{array}$ & $\begin{array}{c}0,59 * * * \\
{[0,17]}\end{array}$ & $\begin{array}{c}1,09 * * * \\
{[0,20]}\end{array}$ \\
\hline Urbanização & $\begin{array}{c}0,09 \\
{[0,10]}\end{array}$ & $\begin{array}{c}0,10 \\
{[0,07]}\end{array}$ & $\begin{array}{l}-0,01 \\
{[0,02]}\end{array}$ & $\begin{array}{c}0,01 \\
{[0,02]}\end{array}$ & $\begin{array}{l}0,07^{*} \\
{[0.04]}\end{array}$ & $\begin{array}{l}-0,07 \\
{[0,05]}\end{array}$ & $\begin{array}{c}-0,19 * * * \\
{[0.06]}\end{array}$ \\
\hline População & $\begin{array}{c}-14,06^{* * * *} \\
{[2,29]}\end{array}$ & $\begin{array}{c}-10,96 * * * \\
{[1,38]}\end{array}$ & $\begin{array}{c}-2,46^{* * *} \\
0,52]\end{array}$ & $\begin{array}{c}-2,99 * * * \\
00,43]\end{array}$ & $\begin{array}{c}-5,69^{* * *} \\
{[0,76]}\end{array}$ & $\begin{array}{c}-5,81 * * * \\
{[0,80]}\end{array}$ & $\begin{array}{c}-7,62^{* * *} \\
{[0,93]}\end{array}$ \\
\hline Constante & $\begin{array}{c}122,83 * * * \\
{[12,75]}\end{array}$ & $\begin{array}{c}114,84^{* * *} * \\
{[12,02]}\end{array}$ & $\begin{array}{c}36,27 * * * \\
{[5,66]}\end{array}$ & $\begin{array}{c}34,29 * * * \\
{[4,28]}\end{array}$ & $\begin{array}{c}68,12^{* * * *} \\
{[8,75]}\end{array}$ & $\begin{array}{c}58,61^{* * * *} \\
{[8,27]}\end{array}$ & $\begin{array}{c}78,99 * * * \\
{[10,45]}\end{array}$ \\
\hline$R^{2}$ & 0,051 & 0,068 & 0,021 & 0,024 & 0,024 & 0,034 & 0,047 \\
\hline Observações & 3.345 & 3.345 & 3.345 & 3.345 & 3.345 & 3.345 & 3.345 \\
\hline \multicolumn{8}{|c|}{ Painel B: Transferências do governo estadual } \\
\hline $\begin{array}{l}\text { Coeficiente } \\
{[\text { Erro-padrão] }}\end{array}$ & $\begin{array}{c}\text { Média } \\
1999-2000\end{array}$ & $\begin{array}{c}\text { Média } \\
2001-2002\end{array}$ & $\begin{array}{c}\text { Média } \\
2003-2004\end{array}$ & $\begin{array}{c}\text { Média } \\
2005-2006\end{array}$ & $\begin{array}{c}\text { Média } \\
2007-2008\end{array}$ & $\begin{array}{c}\text { Média } \\
2009-2010\end{array}$ & $\begin{array}{c}\text { Média } \\
2011-2012\end{array}$ \\
\hline Alinhamento & $\begin{array}{c}3,73 \\
{[2,92]}\end{array}$ & $\begin{array}{c}5,35 \\
{[3,36]}\end{array}$ & $\begin{array}{l}1,25^{* *} \\
{[0,60]}\end{array}$ & $\begin{array}{c}2,91 * * * \\
{[1,10]}\end{array}$ & $\begin{array}{c}6,56^{* * *} \\
{[1,50]}\end{array}$ & $\begin{array}{c}2,86^{* *} \\
{[1,19]}\end{array}$ & $\begin{array}{c}3,16^{* *} \\
{[1,40]}\end{array}$ \\
\hline Fragmentação & $\begin{array}{l}-7,41 \\
{[6,39]}\end{array}$ & $\begin{array}{l}-2,06 \\
{[9,93]}\end{array}$ & $\begin{array}{l}-0,78 \\
{[2,09]}\end{array}$ & $\begin{array}{l}-6,66 \\
{[4,60]}\end{array}$ & $\begin{array}{l}-5,55 \\
{[6,11]}\end{array}$ & $\begin{array}{l}-4,24 \\
{[3,85]}\end{array}$ & $\begin{array}{c}3,18 \\
{[5,36]}\end{array}$ \\
\hline Jovens & $\begin{array}{c}0,60 \\
{[0,86]}\end{array}$ & $\begin{array}{l}1,30 \\
{[1,50]}\end{array}$ & $\begin{array}{c}-0,18^{* * *} * \\
{[0,07]}\end{array}$ & $\begin{array}{c}0,07 \\
{[0,09]}\end{array}$ & $\begin{array}{l}-0,13 \\
{[0,15]}\end{array}$ & $\begin{array}{c}0,91 * * * \\
0,14]\end{array}$ & $\begin{array}{c}0,52^{* * *} \\
{[0,10]}\end{array}$ \\
\hline Urbanização & $\begin{array}{c}0,37 * * * \\
0,12]\end{array}$ & $\begin{array}{c}0,32 * * \\
{[0,15]}\end{array}$ & $\begin{array}{c}0,05 * * * \\
0,02]\end{array}$ & $\begin{array}{l}0,05^{*} \\
{[0,03]}\end{array}$ & $\begin{array}{c}0,09 * * * \\
0,03]\end{array}$ & $\begin{array}{c}0,08^{* *} \\
{[0,03]}\end{array}$ & $\begin{array}{c}0,06^{* *} \\
{[0,03]}\end{array}$ \\
\hline População & $\begin{array}{c}-9,27 * * * \\
{[2,80]}\end{array}$ & $\begin{array}{c}-9,80^{* *} \\
{[4,98]}\end{array}$ & $\begin{array}{c}-2,08 * * * \\
{[0,36]}\end{array}$ & $\begin{array}{c}-2,32 * * * \\
{[0,43]}\end{array}$ & $\begin{array}{c}-3,59 * * * \\
{[0,69]}\end{array}$ & $\begin{array}{c}-3,94^{* * *} \\
{[0,58]}\end{array}$ & $\begin{array}{c}-3,23 * * * \\
{[0,62]}\end{array}$ \\
\hline Constante & $\begin{array}{c}63,03^{* * * *} \\
{[11,14]}\end{array}$ & $\begin{array}{c}45,33^{* * * *} \\
{[11,99]}\end{array}$ & $\begin{array}{c}25,88^{* * * *} \\
{[3,80]}\end{array}$ & $\begin{array}{c}25,94 * * * \\
{[5,14]}\end{array}$ & $\begin{array}{c}38,88^{* * * *} \\
{[8,60]}\end{array}$ & $\begin{array}{c}19,15^{* * *} \\
{[4,86]}\end{array}$ & $\begin{array}{c}17,67 * * * \\
{[4,88]}\end{array}$ \\
\hline$R^{2}$ & 0,018 & 0,009 & 0,023 & 0,014 & 0,021 & 0,045 & 0,013 \\
\hline
\end{tabular}

Fonte: elaboração própria

Nota: erro-padrão robusto entre colchetes; $* * *=$ Significante a $1 \% ; * *=$ Significante a $5 \%{ }^{*}{ }^{*}=$ Significante a $10 \%$

sugerem um aumento de $\mathrm{R} \$ 3,16$ per capita caso o chefe do executivo local seja alinhado com o chefe do executivo estadual, o que representa um aumento significativo da ordem de $48 \%$ em relação à média observada neste mesmo biênio. São observados parâmetros positivos em todos os períodos, e estatisticamente significantes para todos os posteriores ao biênio 2003-2004. Os efeitos dos demais regressores são, em geral, estatisticamente nulos, exceto para a urbanização e população total, cujos parâmetros são positivos e negativos entre as estimações, respectivamente.

Dando prosseguimento à análise dos resultados, a Tabela 7 apresenta os resultados referentes ao procedimentos Time D, Grantor D e Triple D nos Painéis A, B e C, respectivamente. Para o primeiro deles, tanto no caso das Transferências de capital do governo federal como no caso das Transferências de capital do governo estadual, note que o coeficiente associado às transferências é sempre positivo e estatisticamente significante, ou seja, quando um município não é alinhado com o governo federal em um dado momento e a partir do período seguinte passa a sê-lo, observa-se um aumento da ordem de $\mathrm{R} \$ 2,63$ per capita. Já no caso do governo estadual, este aumento é da ordem de $\mathrm{R} \$ 2,93$ per capita.

Por sua vez, os resultados referentes ao procedimento Grantor D corroboram a 


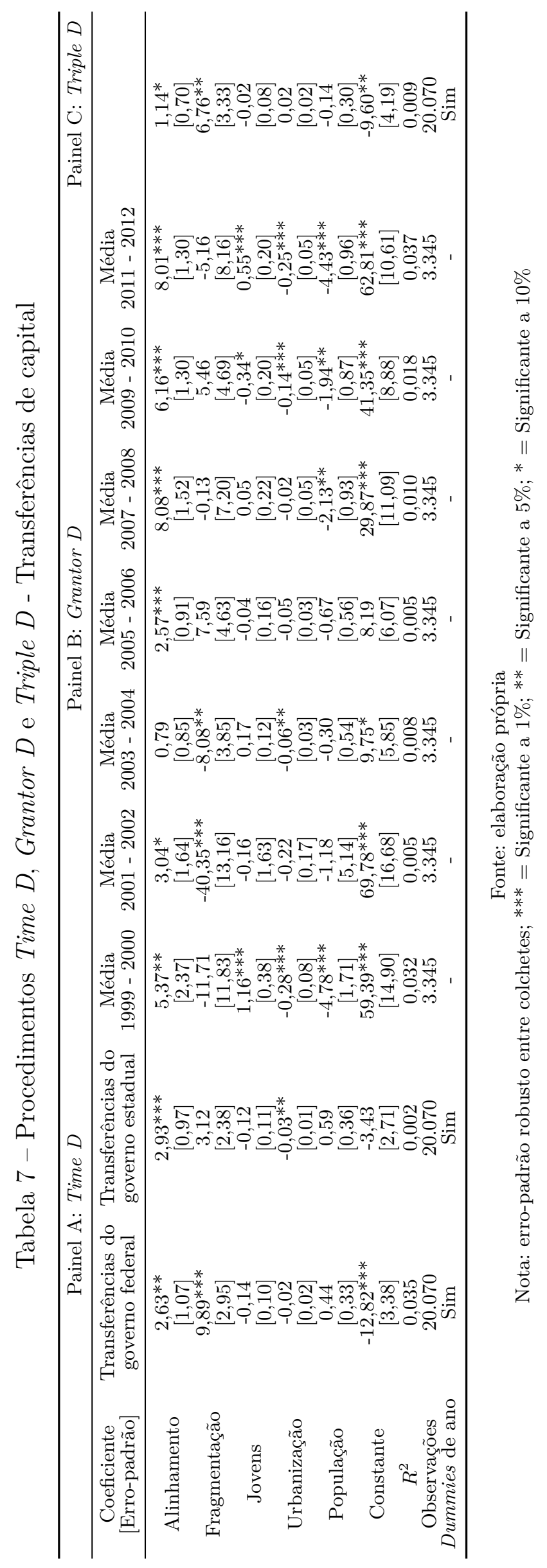


percepção de efeito positivo do alinhamento partidário sobre as transferências fiscais. Todas as regressões exibem parâmetros positivos para a dummy de alinhamento e, à exceção do biênio 2003-2004, o coeficiente é estatisticamente significante em todos os períodos.

Finalmente, discute-se o resultado obtido por meio do procedimento Triple $D$, que contempla as variações temporais, seccionais e entre níveis de governo. Este resultado é particularmente importante uma vez que quando são consideradas essas três fonte de variação, os resultados continuam indicando um efeito positivo, da ordem de $\mathrm{R} \$ 1,14$ por habitante, reforçando, portanto, a percepção de que o alinhamento afeta positivamente os repasses por meio das Transferências de capital.

\subsubsection{Análise de robustez}

De forma geral, os resultados apresentados anteriormente sugerem que muito embora o efeito do alinhamento partidário sobre a rubrica Outras transferências correntes seja em geral estatisticamente nulo, o efeito sobre as Transferências de capital é, por outro lado, positivo. Portanto, estes resultados sugerem que o segundo desses dois tipos de recursos parece ser especialmente utilizado pelo governo central e pelos governos estaduais como uma forma de se destinar recursos à localidades politicamente estratégicas.

Com o objetivo de testar a consistência destes resultados, são apresentados em sequência dois exercícios complementares. No primeiro deles, são estimadas regressões utilizando uma medida alternativa de alinhamento partidários dos municípios com o governo central. As Tabelas 8 e 9 apresentam os resultados referentes às Outras transferências correntes e às Transferências de capital, respectivamente, considerando alternativamente uma variável dummy que assume 1 caso o prefeito seja membro de um partido que tenha feito parte da coligação vencedora e/ou tenha comandado algum ministério durante o período abordado neste artigo (e 0 caso contrário). Esta variável, mais geral do que a medida de alinhamento utilizada anteriormente, procura contemplar a possibilidade de que ainda que um partido não tenha sido membro da coligação vencedora das eleições presidenciais, o mesmo pode ter se aliado ao governo central após as eleições recebendo em troca a indicação de algum ministro - isto é o que ocorre, por exemplo, com o PMDB e o PR, que apesar de não terem sido membros da coligação vencedora nas eleições presidenciais de 2002, comandaram o Ministério das comunicações e o Ministério dos transportes, respectivamente, entre 2004 e 2006.

O segundo exercício, por sua vez, procura lidar com um comportamento relativamente comum por parte dos políticos brasileiros, qual seja, a mudança de partido. Os resultados apresentados anteriormente assumem que uma vez eleito por determinado partido, o prefeito não mudou de agremiação durante todo o seu mandato. Este pressuposto é especialmente questionável no caso brasileiro e, em nosso caso, é provável que prefeitos membros de partidos não alinhados ao governo estadual ou federal transitem para partidos alinhados justamente com o intuito de receber apoio dos níveis superiores de governo - as transferências fiscais seriam um mecanismo bastante provável por meio do qual esse suporte poderia se dar. Assim, haveria uma relação endógena entre transferências e alinhamento. 
Os dados disponibilizados até recentemente pelo TSE permitiam identificar a filiação partidária dos políticos brasileiros somente a partir dos dados das candidaturas às eleições. Tomando o caso de duas eleições municipais sucessivas como exemplo, os dados disponíveis permitiam saber que um candidato "X" pertencia ao partido "A" na eleição de 2004 e se este ainda pertencia ao partido A ou se havia migrado para um partido B na eleição seguinte, de $2008^{18}$. Contudo, não era possível saber em que ano se deu esta mudança, ou seja, não era possível saber de qual partido o prefeito era membro ao longo de cada ano de seu mandato.

Recentemente, o TSE passou a disponibilizar dados de filiação partidária, por meio da qual foi possível rastrear quais prefeitos mudaram de partido e em qual ano essa mudança se deu ${ }^{19}$. Isto permitiu definir quais prefeitos de nossa amostra mudaram de agremiação e quais permaneceram. Dado que a mudança de partido pode ser endógena às transferências, o segundo exercício contempla apenas aqueles municípios cujo prefeito não mudou de partido durante seu mandato. Dada a necessidade de um painel balanceado (conforme já explicado anteriormente), caso o prefeito de um município tenha mudado de partido em qualquer mandato vigente dentro da amostra, então esse município é totalmente excluído das estimações - tal procedimento fez com que a amostra sofresse redução de 3.345 para 2.070 municípios, o que ainda parece ser uma quantidade razoável de observações para a realização dos testes ${ }^{20}$.

Tanto no primeiro exercício como no segundo, visando facilitar a exposição dos resultados, são apresentados apenas os parâmetros referentes à dummy de alinhamento, sendo que os resultados completos (isto é, todos os parâmetros estimados) são apresentados no Apêndice A desta tese.

Os resultados referentes ao alinhamento com a coligação presidencial e/ou com os partidos dos ministros são apresentados na Tabela 8 para as Outras transferências correntes e na Tabela 9 para as Transferências de capital. Quando esta medida mais geral de alinhamento é considerada, nota-se que algumas estimações para as Outras transferências correntes que antes exibiam coeficientes estatisticamente nulos passam agora a exibir parâmetros estatisticamente significantes e positivos para a dummy de alinhamento, como ocorre nos anos de 1999, 2009 e 2010 para o procedimento Cross Section, e nos anos de 1999, 2005, 2006, 2009 e 2010 para o procedimento Grantor D. Já para os procedimentos Time D e Triple D, entre 2008 e 2011, para ambos os procedimentos, os resultados que antes eram negativos passam a ser positivos, corroborando portanto o efeito positivo do alinhamento com o gabinete ministerial sobre o recebimento desses recursos.

No caso das Transferências de capital, por sua vez, o efeito positivo para a média

18 Condicional a ter concorrido neste último ano eleitoral, caso contrário, sua filiação partidária não seria divulgada.

19 Para tal, foi definido um método que associa os dados de filiação partidária, por um lado, e os prefeitos dos municípios brasileiros, por outro. A associação entre essas duas bases se deu com base no título de eleitor, sendo também considerados o nome do indivíduo e sua data de nascimento como forma de checagem ou até mesmo como critérios principais de procura dado que há erros de digitação do título eleitoral dos filiados/candidatos.

20 Há um esclarecimento importante quanto ao segundo exercício: além dos prefeitos, os governadores e até mesmo o Presidente da República podem teoricamente mudar de partido, o que naturalmente alteraria a variável que mensura o alinhamento. Contudo, não ocorreram mudanças de partido nesses dois cargos específicos na amostra explorada neste estudo. 
do biênio 2003-2004 passa a ser estatisticamente significante para o procedimento Cross Section, fortalecendo o efeito positivo sobre a transferência desses recursos para os municípios alinhados. No caso do método Triple $D$, contudo, é possível notar que o alinhamento, muito embora mantenha o sinal positivo, deixa de exibir significância estatística. De todo modo, os resultados deste primeiro exercício complementar sugerem que os ministérios parecem atuar como veículos importantes na canalização de recursos fiscais para os governos locais quando o alinhamento partidário é observado.

No caso do segundo exercício, cuja amostra contempla apenas aqueles municípios em que não houve mudança de partido do prefeito, os resultados são apresentados na Tabela 10 para as Outras transferências correntes e na Tabela 11 para as Transferências de capital. Para o primeiro desses recursos, não há mudanças significativas dos resultados e quando há, reforçam aqueles apresentados na seção 2.4.1. A título de ilustração, notase que as novas estimações geram coeficientes positivos e estatisticamente positivos, no caso do procedimento Cross Section, nos anos de 2001, 2006 e $2011^{21}$ para os repasses do governo federal, e nos anos de 2003 e 2004, para os repasses do governo estadual. Já para o procedimento Grantor D, o coeficiente positivo passa a ser estatisticamente significante para o ano de 2001.

Em relação às Transferências de capital, por sua vez, as estimações também apresentam variações pontuais, como os coeficientes positivos que passam a ser estatisticamente significantes no caso do procedimento Cross Section para as transferências do governo estadual na média dos biênios 1999-2000 e 2001-2002 e para as transferências do governo federal na média do biênio 2003-2004, mas sem alterar significativamente os resultados observados anteriormente. Assim sendo, estes dois exercícios adicionais continuam corroborando a percepção de que o alinhamento partidário parece influenciar positivamente as transferências fiscais recebidas pelos municípios brasileiros, especialmente as Transferências de capital.

\subsection{Considerações finais do capítulo}

O objetivo deste estudo foi analisar o comportamento das transferências fiscais recebidas pelos municípios brasileiros tendo em vista o alinhamento partidário com seus respectivos governos estaduais e com o governo federal. Analisando-se um painel com mais de 3.300 municípios entre os anos de 1999 e 2012, o estudo investigou o comportamento de dois grupos de transferências, quais sejam, as Outras transferências correntes e as Transferências de capital, oriundas tanto do governo central como dos governos estaduais. O procedimento empírico utilizado, baseado no trabalho de Sole-Olle e Sorribas-Navarro (2008), leva em conta todas as variações do alinhamento, quais sejam, que ocorrem ao longo do tempo, entre municípios e entre diferentes níveis de governo.

Em geral, os resultados sugerem que as Outras transferências correntes são pouco influenciadas pelo alinhamento partidário, especialmente as transferidas pelo governo federal. No caso dos recursos obtidos junto ao governo estadual, os resultados indicam efeito positivo do alinhamento somente em alguns períodos específicos, impossibilitando assim

$\overline{21}$ Para o ano de 2003, o coeficiente, que já era negativo no primeiro conjunto de estimações, passa a ser estatisticamente significante quando esta nova amostra é considerada. 


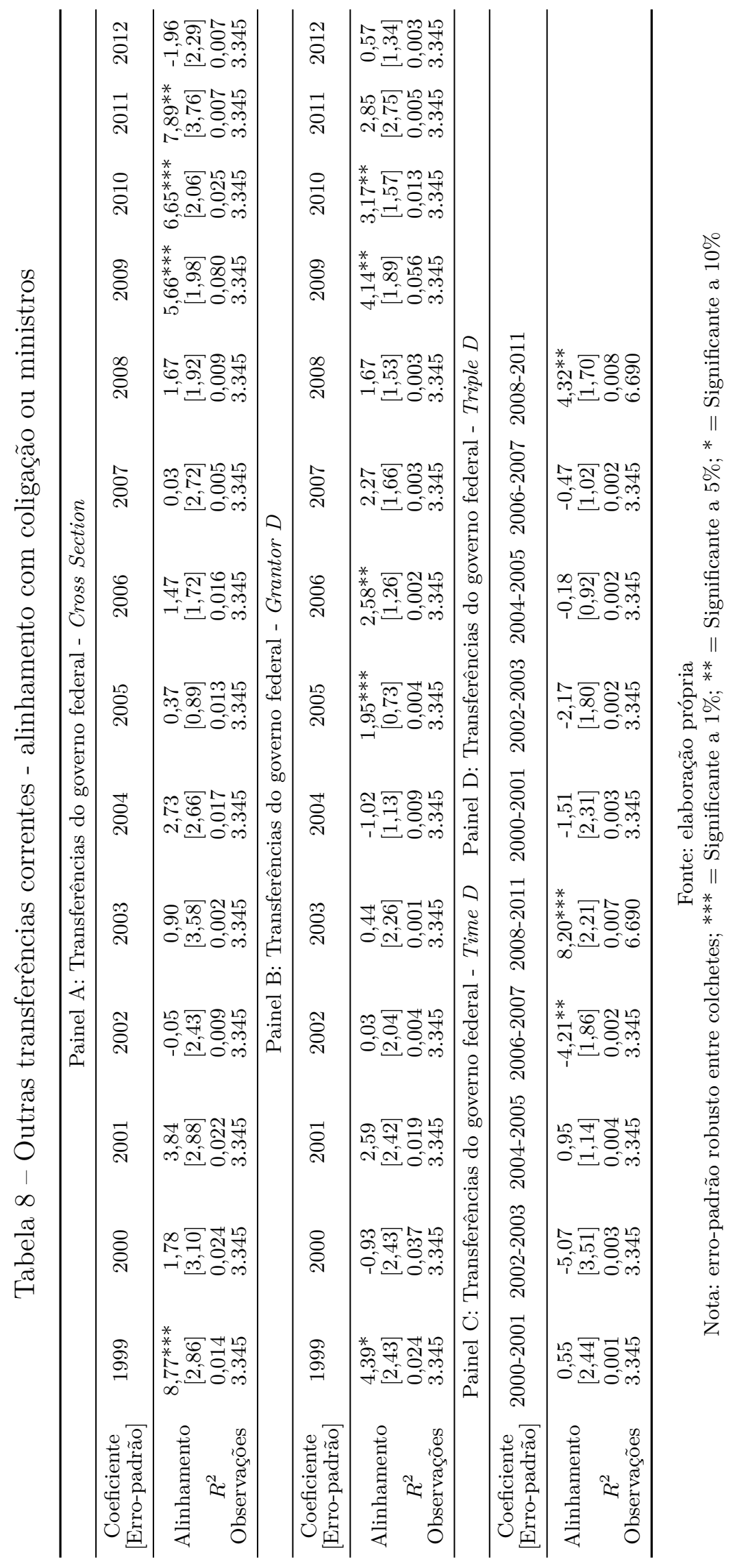




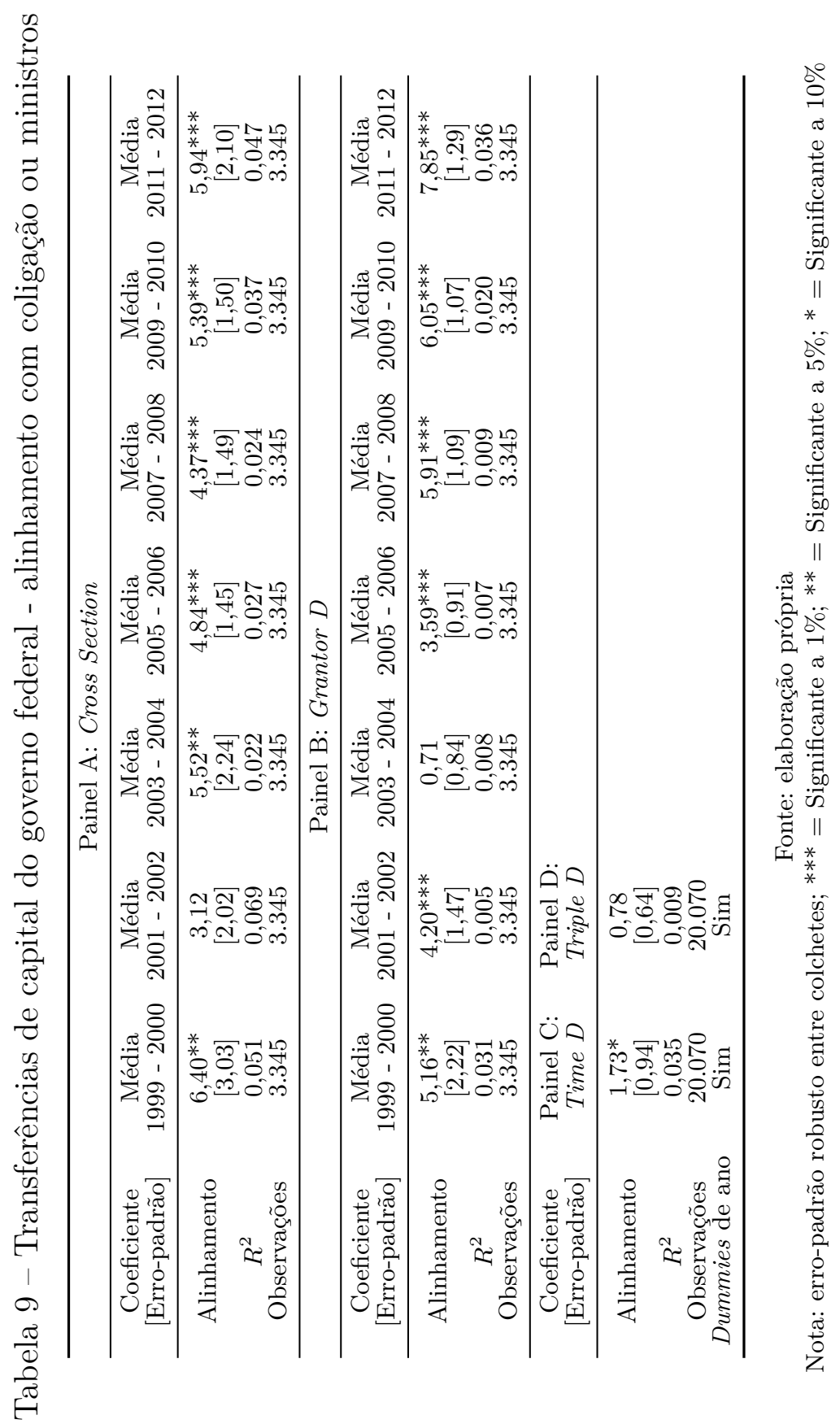




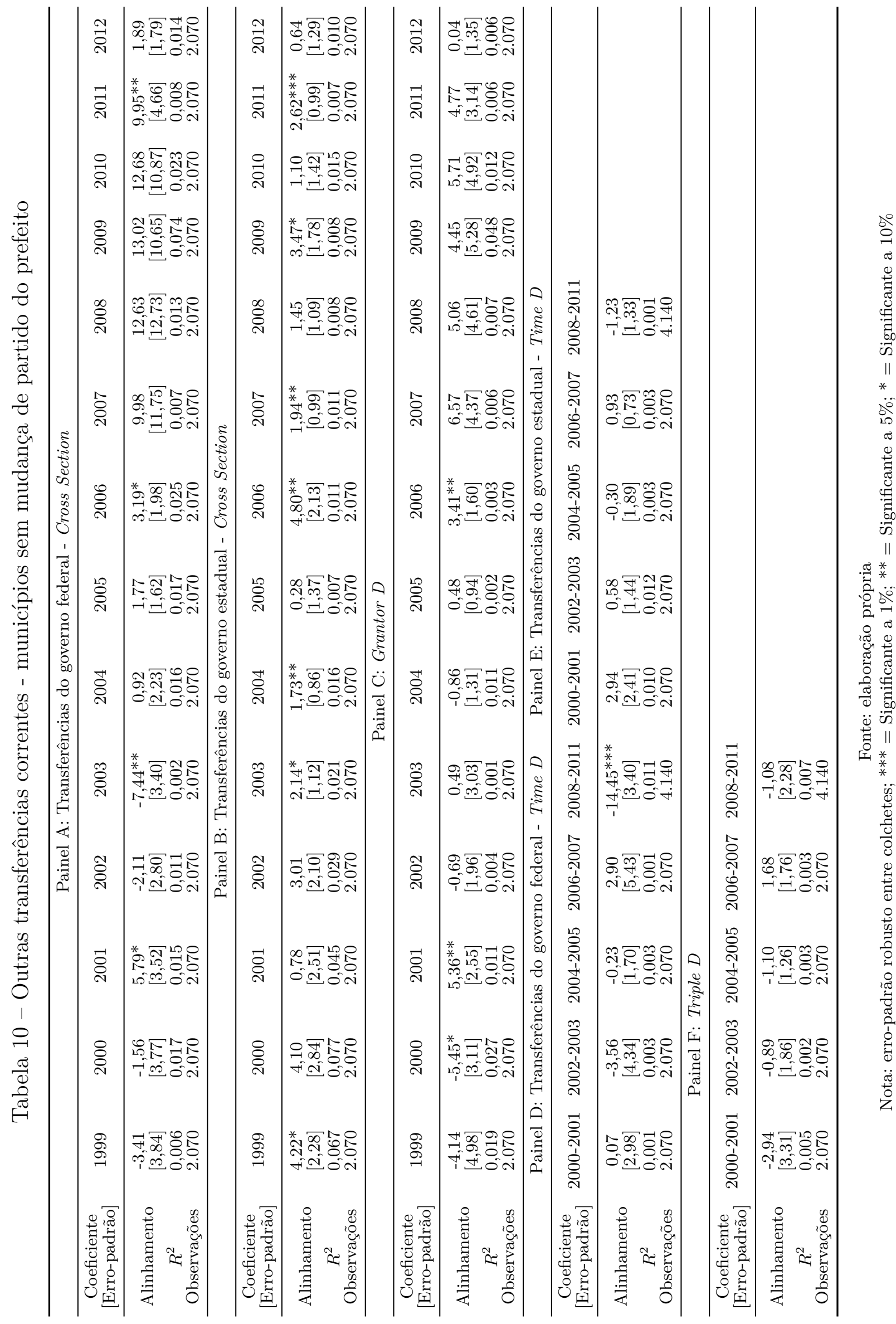




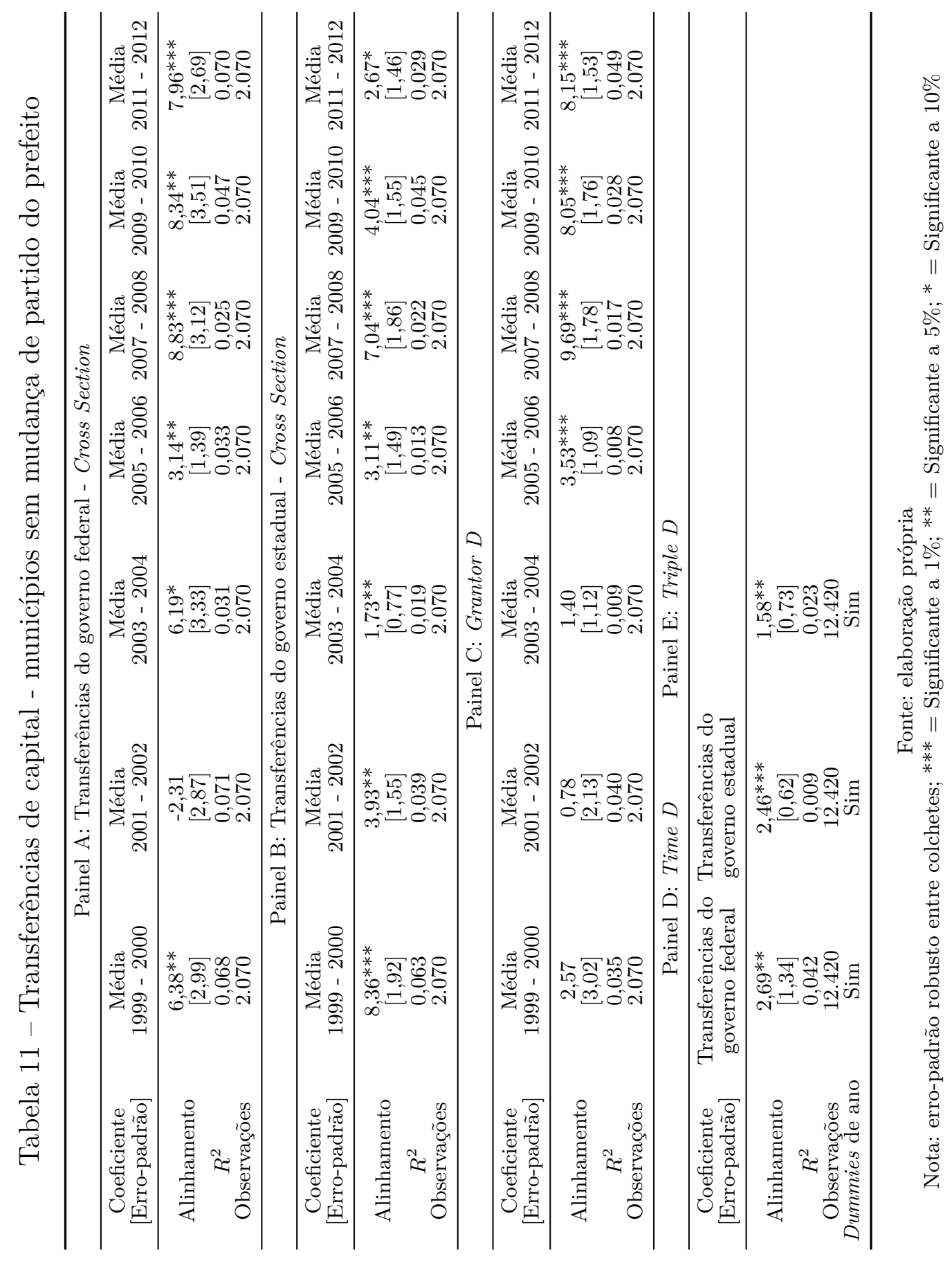


chegar à conclusões mais rigorosas para esta rubrica. Por fim, a variação do alinhamento entre diferentes níveis de governo também não altera de forma significativa os resultados obtidos por meio dos demais métodos aqui explorados.

Já em relação às Transferências de capital, os resultados são consideravelmente distintos, pois sinalizam, em geral, que o alinhamento influencia positivamente o volume de recursos transferidos, sendo este resultado especialmente válido para os últimos anos do período amostral aqui analisado. Desta forma, tomados em conjunto, os resultados apresentados neste artigo indicam que as Transferências de capital são especialmente sujeitas ao efeito do alinhamento partidário, resultado relativamente diferentemente do obtido por Brollo e Nannicini (2012).

Outro resultado importante diz respeito à heterogeneidade da preferência dos eleitores: os coeficientes associados à fragmentação de votos ao executivo municipal nem sempre apresentam significância estatística e quando isto ocorre, assumem sinais positivos em alguns casos e negativo em outros. Este resultado sugere não haver um efeito claro de uma maior homogeneidade ou heterogeneidade das preferências dos eleitores sobre o volume de recursos recebidos a partir do governo federal ou estadual. Efeito nulo também parece ser exercido pelas características demográficas dos municípios. A exceção fica por conta do tamanho da população, que em geral afeta negativamente o montante recebido por habitante. Este resultado pode ser explicado pelo fato de um dado montante de transferências beneficiar naturalmente localidades com menor número de habitantes, ou seja, o valor por habitante tende naturalmente a diminuir conforme aumenta o porte populacional dos municípios. Grossman (1994) argumenta que a utilidade marginal recebida por um grantor (governo federal ou estadual) tende a ser menor quanto maior a população, dado que os benefícios das transferências tendem a ser divididos entre um número maior de agentes, o que pode explicar o resultado obtido. Contudo, ainda segundo esta referência, esse efeito pode ser neutralizado pelo fato de localidades maiores terem mais representantes políticos nas casas legislativas dos níveis superiores de governo, o que poderia aumentar o volume das transferências. Seja como for, as características demográficas parecem exercer efeito moderado sobre as mesmas.

Foram realizados dois exercícios adicionais com o objetivo de verificar a consistência destes resultados. O primeiro deles considerou uma medida mais geral de alinhamento com o governo federal contemplando não só os partidos da coligação vencedora das eleições presidenciais, mas também os partidos dos ministros da República. Os resultados sugerem que o alinhamento com os ministérios parece ser um mecanismo importante de transferência de recursos do governo federal aos municípios, isto é, municípios geridos por prefeitos cujos partidos fazem parte da administração federal parecem ser beneficiados com mais transferências do governo federal. O segundo exercício, por sua vez, considerou uma sub-amostra contemplando somente aqueles municípios onde não houve mudança de partido do prefeito - neste caso, os resultados não sofrem grandes alterações frente aos obtidos com a amostra completa de municípios.

Tomados em seu conjunto, os resultados indicam que o alinhamento partidário dos executivos municipais com seu respectivo executivo estadual ou com o executivo federal é um fator importante na determinação dos recursos obtidos via transferências. Se os eleitores utilizam esta informação na decisão de escolha dos chefes do executivo local, 
pode ser mais verdadeira a hipótese levantada por Ferreira e Bugarin (2007), qual seja, de que os eleitores não escolheriam policymakers pela sua "competência" propriamente dita, mas sim pela possibilidade desses obterem maiores recursos junto aos níveis superiores de governo, distorcendo, portanto, os incentivos sob os quais atuam os eleitores e os governantes. Eventualmente, no caso brasileiro, o conceito de policymaker "competente" seja justamente o de governante capaz de angariar maiores recursos junto aos níveis superiores de governo. Muito embora isso possa ser visto como um comportamento individualmente ótimo do ponto de vista dos governantes locais, trata-se naturalmente de uma solução com importantes consequências do ponto de vista coletivo, especialmente para a gestão fiscal do governo federal e estadual. 


\section{Alinhamento partidário e empréstimos oficiais via BNDES: uma análise para os estados e municípios brasileiros}

\subsection{Introdução}

Conforme já discutido no Capítulo 2 desta tese, existem diversos estudos que buscam evidências de um eventual efeito do alinhamento partidário sobre as transferências fiscais recebidas por unidades locais a partir de instâncias superiores de governo. Esse resultado, tipicamente relacionado a sistemas federativos, tende a ser mais forte quanto maior a dependência dos primeiros em relação aos recursos transferidos pelos segundos, como é o caso do Brasil.

O estudo apresentado neste capítulo analisa outro mecanismo por meio do qual instâncias superiores de governo podem influenciar a transmissão de recursos para níveis inferiores, qual seja, a concessão de empréstimos oficiais via BNDES. Em particular, o estudo apresentado neste capítulo tem como objetivo analisar empiricamente se municípios e governos estaduais cujos chefes de executivo (prefeitos e governadores, respectivamente) são politicamente alinhados com o governo federal apresentam maiores chances de obtenção de financiamento junto ao referido banco, ou então, se esses empréstimos são maiores ou tomados em condições de amortização mais favoráveis, comparativamente aos municípios e estados não alinhados. Assim sendo, diferentemente das transferências fiscais, que são feitas diretamente, o objetivo é investigar um mecanismo indireto de interação entre o governo federal, por um lado, e os governos estaduais e municipais, por outro, via BNDES.

Este estudo interage e, portanto, visa trazer contribuições a diferentes literaturas. A primeira delas é a que discute a influência de fatores políticos sobre a interação entre diferentes níveis de governo - a literatura que versa sobre o efeito do alinhamento partidário sobre as transferências fiscais, já discutida no capítulo anterior desta tese, enquadra-se nesta literatura mais geral. A segunda é a literatura, já bastante vasta, que versa sobre a existência e a atuação de bancos públicos em geral e, em particular, dos bancos públicos de desenvolvimento, entre os quais está o BNDES. Neste caso, há três áreas relevantes: uma delas, que apresenta argumentos favoráveis à existência dessas instituições; outra que apresenta críticas à sua atuação e, finalmente, uma terceira literatura, ampla e composta predominantemente por trabalhos nacionais, que versa especificamente sobre o BNDES.

Neste capítulo, são analisados dados referentes aos financiamentos concedidos pelo BNDES à administração pública direta dos estados e municípios brasileiros, com informações entre os anos de 2002 e 2012 para os municípios, e entre 2002 e 2014 para os estados. Por meio de regressões do tipo Heckman para controle de viés de seleção e por meio da técnica de regressão descontínua (Regression Discontinuity Design ou RDD), os resultados obtidos indicam que o efeito do alinhamento partidário com o governo federal é nulo no caso dos municípios, ou seja, ter um prefeito alinhado com o governo federal não implica em maiores montantes de financiamento obtidos junto ao BNDES nem que tais empréstimos são obtidos em condições mais favoráveis de devolução. Contudo, no caso dos estados, os resultados indicam que governadores cujos partidos fazem parte do governo 
federal obtém empréstimos de maior montante e sujeitos à condições mais favoráveis de devolução.

Este capítulo está organizado da seguinte forma. A seção 3.2 apresenta a revisão da literatura, que primeiramente discute a atuação dos bancos públicos (entre eles, os de desenvolvimento) e em um segundo momento, discute referências que versam especificamente sobre o BNDES. A seção 3.3, por sua vez, descreve os procedimentos metodológicos e os dados utilizados neste estudo. A seção 3.4 apresenta os resultados, separadamente para os municípios e para os estados. Por fim, a seção 3.5 apresenta as considerações finais do capítulo.

\subsection{Revisão da literatura}

\subsubsection{Uma breve revisão da literatura sobre o BNDES}

O BNDES é uma entidade autárquica, com autonomia administrativa, cujo objetivo central é auxiliar a política de investimentos do Estado. Criado em 1952 com o objetivo de incentivar o desenvolvimento econômico do país, o banco estava inserido em um contexto econômico e social muito diferente do observado atualmente: a economia era predominantemente agrícola, a população brasileira somava pouco mais de $50 \mathrm{mi}$ lhões de habitantes e a indústria ainda era incipiente. Em particular, o então BNDE seria responsável por prover financiamento para o "Plano de Reaparelhamento" e por outras operações financeiras, além de realizar análises para identificar os principais problemas do país. Em seus primeiros anos, os recursos foram provenientes principalmente do Fundo de Reaparelhamento Econômico, cuja fonte de recursos era uma taxa adicional sobre o imposto de renda.

O primeiro setor a receber investimentos do banco foi o setor de transportes, com investimentos para a remodelagem das linhas de cargas e de passageiros entre Rio de Janeiro, São Paulo e Belo Horizonte, e para a ampliação de aeroportos. Já nos anos 60, o BNDE apoiou a criação da Centrais Elétricas Brasileiras S.A., passando também a se dedicar a outros setores, em especial à indústria de bens de capital. Nesse período ocorreu a criação da subsidiária Agência Especial de Financiamento Industrial (FINAME), voltada para a aquisição de bens de capital produzidos no Brasil. Já nos anos 70, a instituição ampliou sua atuação junto às empresas privadas, principalmente às indústrias ligadas ao II ${ }^{\circ}$ Plano Nacional de Desenvolvimento (II ${ }^{\circ}$ PND).

Apenas na década seguinte o Banco recebeu o "S" de seu atual nome, aumentando o leque de atuação da instituição. A inclusão da área social se deu por meio da criação do Fundo de Investimento Social (Finsocial), cuja fonte de recursos era um imposto cobrado sobre a renda e cujo objetivo era apoiar programas de alimentação, habitação popular, saúde, educação e amparo ao pequeno agricultor. Também na década de 80, a subsidiária BNDES Participações S.A. (BNDESPAR) fez a primeira oferta pública de ações (da Petrobras), um passo importante na atuação do banco no mercado de capitais. Já nos anos 90, o BNDES foi o responsável pelo Programa Nacional de Desestatização, sendo fundamental no processo de privatização. Nessa década, a instituição aumentou sua atuação em projetos privados de infraestrutura e de modernização de setores produtivos e 
começou a apoiar micro, pequenas e médias empresas. Financiamentos de projetos com preocupação ambiental e ligados a cultura também tiveram início nesse período (BAST, 2015). Já nos mais recentes, a estratégia do BNDES passou por redefinições a partir do início da década de 2000, passando a ser um dos principais instrumentos de incentivo ao investimento. Para tanto, houve aumento significativo dos desembolsos da instituição, que se tornou a maior financiadora do Programa de Aceleração do Crescimento (PAC).

Atualmente, o BNDES está entre os maiores bancos de desenvolvimento do mundo, com ativo total que ultrapassa $R \$ 900$ bilhões e patrimônio líquido superior a $R \$ 30$ bilhões. Os recursos financeiros do BNDES são provenientes principalmente do Tesouro Nacional, sendo atualmente responsável por mais 55\% do passivo total do Banco. A segunda fonte principal de recursos é o Fundo de Amparo ao Trabalhador (FAT), com pouco mais de $20 \%$ do passivo total. Outras fontes governamentais e captações externas compõem as outras origens de recursos utilizadas atualmente.

O BNDES aumentou consideravelmente seu volume de desembolsos ao longo dos últimos anos, sendo que a partir de 2009 os valores foram sempre superiores à $\mathrm{R} \$ 100$ bilhões, chegando a $\mathrm{R} \$ 190,4$ bilhões em 2013. Esse aumento do valor dos desembolsos reflete a mudança de estratégia da instituição, que se tornou recentemente a principal incentivadora de investimentos do país. De fato, o banco tem participação importante no mercado de crédito brasileiro: em 2013, por exemplo, sua participação no estoque total de crédito foi da ordem de 20\%. Em outras métricas a importância do BNDES também pode ser percebida: seus desembolsos sobre a Formação Bruta de Capital Fixo chegaram a quase $22 \%$, ao passo que a participação no PIB chegou a quase $4 \%$ no mesmo período. Ainda em 2013, o BNDES ainda respondeu por 35\% do volume total de crédito para pessoa jurídica (BAST, 2015). Contudo, apesar da sua inegável importância para o mercado financeiro brasileiro, o banco passou a ser questionado em função do seu perfil recente de atuação.

Em relação à literatura sobre o BNDES, há uma ampla gama de estudos, formada predominantemente por obras nacionais, que versa especificamente sobre a sua atuação. De fato, um projeto realizado recentemente pela Faculdade de Economia, Administração e Contabilidade de Ribeirão Preto da Universidade de São Paulo ${ }^{22}$, contabilizou mais de mil publicações (livros, artigos, dissertações e teses, entre outros) que versam sobre o BNDES, seja tendo o banco como foco especifico das obras, seja tendo o banco entre os temas abordados.

Por meio deste projeto, foi possível constatar uma mudança significativa no perfil de estudos referentes ao banco. A maior parte dos estudos mais antigos versa sobre temas como industrialização e infraestrutura, como os trabalhos de Viana (1981), Najberg (1989), Bonelli e Pinheiro (1994), Monteiro-Filha (1994), Ferreira (1995) e Curralero (1998), algumas das obras mais citadas por toda a literatura sobre o banco, além naturalmente de livros clássicos como Lessa (1983) e Baer (1988), entre outros. A literatura mais recente, contudo, tem dado ênfase à discussão dos efeitos dos empréstimos concedidos pelo banco: a maioria, de perfil empírico, têm discutido especialmente o efeito dos

22 Projeto este financiado pelo próprio BNDES, no âmbito do Projeto "Levantamento e avaliação da literatura econômica sobre o BNDES - Chamada Pública BNDES FEP Pesquisa Científica $\mathrm{n}^{\circ}$ 03/2011 - FEP Literatura Econômica", concluído em 2013. Os relatórios deste projeto estão disponíveis em < http://www.bndes.gov.br/SiteBNDES/bndes/bndes_pt/Institucional/Apoio_Financeiro/ Apoio_a_estudos_e_pesquisas/BNDES_FEP/pesquisa_cientifica/literatura_economica.html $>$. 
financiamentos recebidos pelo setor produtivo da economia. Segundo esta literatura, seria esperada uma melhora no desempenho das empresas beneficiadas com empréstimos do BNDES porque, sem esse tipo de instituição, muitos projetos viáveis não conseguiriam ser executados por falta de financiamento de longo prazo no mercado privado (BRUCK, 1998).

Nesta literatura, uma das principais referências é o trabalho realizado por Negri et al. (2011), que analisam o impacto de linhas de crédito tanto do BNDES quanto da FINEP $^{23}$ sobre o emprego, produtividade do trabalho e as exportações das empresas beneficiadas. Os autores encontram efeitos positivos desses financiamentos tanto para o emprego quanto para as exportações. Reiff, Santos e Rocha (2007) e Pereira (2007) também encontram efeitos positivos sobre o emprego formal dos municípios beneficiados.

Também com foco nos financiamentos do BNDES para empresas exportadoras, Moreira, Tomich e Rodrigues (2006) encontram indícios de uma relação positiva entre o total exportado e tomada de recursos junto ao BNDES-EXIM. Silva (2010), por sua vez, encontra evidências de que as empresas beneficiadas com empréstimos do BNDES apresentam maior probabilidade de começar a exportar em até três anos após o recebimento dos recursos. Em outro estudo do mesmo autor, Silva (2012) encontra relação positiva entre os empréstimos do BNDES-EXIM e o tempo de permanência das empresas exportadoras no mercado internacional.

Outros autores também avaliaram a eficiência dos empréstimos do BNDES sobre a produtividade das empresas. Esses estudos partem da premissa de que os bancos públicos de desenvolvimento contribuem para diminuir a restrição de crédito que as empresas beneficiadas enfrentariam no mercado privado, permitindo assim um aumento nos investimentos. Contudo, o aumento desses investimentos pode ocorrer tanto via aumento da execução de projetos fracos com tecnologia antiga, o que diminuiria a produtividade, quanto por execução de projetos de nível intermediário com nova tecnologia que, por seu turno, aumentaria a produtividade. Seguindo esta linha de raciocínio, Ottaviano e Sousa (2008) testam quais os efeitos dos empréstimos do BNDES sobre a produtividade das empresas beneficiadas, avaliada pelo valor adicionado do trabalho. Para as empresas maiores, os autores encontram um efeito positivo, mas para projetos menores, encontram efeito negativo ${ }^{24}$.

Outro canal por meio do qual as empresas seriam beneficiadas pelo crédito subsidiado provido pelo BNDES seria a diminuição dos gastos financeiros ao se contrair crédito subsidiado. Seguindo esta linha de raciocínio, Lazzarini et al. (2015) avaliam os efeitos dos empréstimos do BNDES, além da participação do banco na estrutura acionária das empresas, sobre gastos com investimentos e lucratividade. Os autores avaliam qual o impacto

23 Financiadora de Estudos e Projetos, vinculada ao Ministério da Ciência e Tecnologia.

24 Também testando os efeitos sobre a produtividade do trabalho, Sousa (2010) analisa os efeitos dos financiamentos do BNDES sobre os diferentes tipos de custos de implantação de novos projetos, como custo com pesquisa e desenvolvimento e custo fixo de produção. Os resultados sugerem que apesar dos dois tipos de custos sofrerem redução, não há evidências de efeito positivo sobre a produtividade. Coelho e Negri (2010), por sua vez, avaliam a produtividade total dos fatores (PTF) e concluem que as firmas que já apresentavam PTF superior à média tiveram maior efeito positivo sobre a produtividade. Já Ribeiro e Negri (2009) fazem uma análise mais específica, examinando o efeito dos empréstimos do BNDES sobre a PTF de firmas inovadoras, encontrando resultados ambíguos. 
do recebimento de empréstimos do BNDES $^{25}$ sobre o retorno líquido e operacional das empresas, além de analisar os efeitos sobre gastos financeiros e gastos com aquisição de capital. Segundo os resultados obtidos pelos autores, o efeito dos desembolsos do BNDES sobre essas variáveis é nulo, exceto para a medida de gasto financeiro, que diminui com a aquisição de crédito subsidiado. Inoue, Lazzarini e Musacchio (2013), por seu turno, testam especificamente o efeito da participação do BNDESPAR sobre retorno líquido das firmas separando-as por tipo de "propriedade", isto é, se são privadas, públicas ou mistas. Nesse caso, os autores encontram um efeito positivo da participação do BNDESPAR sobre o retorno líquido sobre ativos. No entanto, notam que para empresas públicas o efeito sobre o retorno é negativo, sugerindo que a intervenção pública sobre essas empresas é negativamente avaliada pelos investidores.

Ainda que os trabalhos anteriormente mencionados sugiram a existência de uma ampla literatura analisando os efeitos dos financiamentos providos pelo banco ao setor produtivo da economia, o mesmo não pode ser dito em relação ao financiamento provido ao setor público. De fato, o levantamento realizado no âmbito do projeto desenvolvido entre a FEA-RP/USP e o BNDES sugere a existência de poucas publicações com esse perfil. Entre os poucos trabalhos que analisam o efeito do crédito provido pelo BNDES à administração pública direta, três analisam especificamente a linha de financiamento PMAT (Programa de Modernização da Administração Tributária e da Gestão dos Setores Sociais Básicos). Gadenne (2015) explora dados de municípios brasileiros e encontra resultados que indicam que municípios contemplados com financiamento da modalidade PMAT apresentam aumento da receita tributária. Em uma avaliação semelhante, Barbosa-Filho (2013) também analisa a eficiência do PMAT e encontra resultados positivos, sugerindo que os municípios que participaram do programa conseguiram aumentar sua arrecadação tributária. Contudo, os resultados obtidos por Bast (2015) indicam que não há aumento da arrecadação tributária por parte dos municípios beneficiados com crédito da referida modalidade, mesmo quando são consideradas regiões geográficas, impostos municipais e períodos distintos de análise. Por sua vez, o estudo de Wegelin (2014) analisa os efeitos dos empréstimos da modalidade Programa de Dinamização Regional (PDR) sobre o PIB e sobre o nível de emprego dos municípios beneficiados pelo referido programa. A autora conclui que a participação no programa trouxe impactos positivos sobre o PIB e o PIB per capita das localidades beneficiadas, muito embora o efeito sobre emprego tenha sido nulo.

\subsubsection{Uma breve revisão da literatura sobre bancos públicos e fatores políticos}

O investimento é um agregado econômico que se diferencia dos demais por ser capaz tanto de elevar a demanda agregada (como é tradicionalmente explorada nos modelos keynesianos, que enfatizam o curto prazo) como de elevar a oferta agregada (conforme os modelos neoclássicos de crescimento econômico, que enfatizam os efeitos de longo prazo). Nesta segunda perspectiva, segundo o trabalho seminal de Solow (1956), o crescimento de longo prazo estaria estreitamente relacionado com a acumulação de capital que, por sua vez, estaria naturalmente associada ao nível de investimento da economia. A partir desta referência, diversos estudos passaram a discutir o efeito de outros fatores

${ }_{25}$ Ou ter o BNDESPAR como acionista. 
sobre o crescimento econômico de longo prazo, como o investimento em pesquisa, desenvolvimento e inovação (ROMER, 1990) e (AGHION; HOWITT, 1992), investimento em capital humano (MANKIW; ROMER; WEIL, 1992), estímulos à entrada de investimento externo (BARRO; MANKIW; MARTIN, 1995), investimentos públicos (BARRO, 1990) e, mais recentemente, investimentos que viabilizem melhores condições ambientais (BROCK; TAYLOR, 2010). A questão que naturalmente se segue é como financiar esses investimentos, que em geral envolvem montantes elevados de recursos e prazos de maturação longos, entre outros fatores e, portanto, exigem condições de financiamento peculiares que permitam viabilizá-los.

Segundo a visão clássica, em boa parte baseada nos trabalhos de Shaw (1973) e McKinnon (1973), um mercado financeiro que funcionasse de forma livre seria suficiente para prover a contento diferentes tipos de crédito (para diferentes tipos de tomadores e para diferentes propósitos para o crédito tomado) e, portanto, não haveria maiores entraves ao financiamento dos investimentos. Neste caso, segundo esses autores, a atuação do governo deveria ser apenas a de supervisionar as instituições financeiras e instituir um aparato jurídico que garantisse os direitos de propriedade e o cumprimento dos contratos. Contudo, conforme argumenta Hermann (2011), em economias em desenvolvimento, cujos mercados financeiros têm geralmente menor poder de provisão de crédito e estão hipoteticamente mais sujeitos às falhas de mercado, entre outros, algum tipo de atuação governamental pode ser necessária. Tal atuação poderia minimizar problemas como custos de transação, assimetria de informação, mercados incompletos e concorrência imperfeita, entre outros (STIGLITZ, 1994). Eventualmente, a atuação do governo no mercado de crédito poderia se dar de forma direta, envolvendo a instituição de um banco público.

Adaptando o raciocínio presente em Sapienza (2004), seria possível analisar a atuação do governo no mercado de crédito com base em três visões, quais sejam, social, de agência e política. Segundo a primeira delas, bancos públicos seriam importantes para maximizar o bem-estar via correção de falhas de mercado, raciocínio esse semelhante ao apresentado no parágrafo anterior. Contudo, ainda que esse argumento seja válido, a atuação do governo no mercado de crédito não necessariamente envolve a constituição de um banco de desenvolvimento, e nem que esse banco de desenvolvimento seja necessariamente público. Pode-se considerar, contudo, argumentos a favor deste tipo específico de instituição.

A existência de um banco de desenvolvimento público pode ser importante, em primeiro lugar, porque na ausência de instituições financeiras privadas dispostas a conceder financiamento de longo prazo, os demandantes deste tipo de empréstimos seriam obrigados a recorrer a sucessivos financiamentos de curto prazo, o que aumentaria o risco dos projetos em virtude de possíveis oscilações das taxas de juros (ou caso essas sejam bruscas), além de outros fatores decorrentes de instabilidade macroeconômica. Em segundo lugar, essas instituições poderiam viabilizar projetos públicos e privados que gerem externalidades econômicas e sociais positivas, como o investimento em infraestrutura, em pesquisa e desenvolvimento, em políticas de inovação e em políticas ambientais, entre outros. Sob um cálculo puramente privado, ou seja, que desconsidere o efeito positivo dessas externalidades, haveria naturalmente menos incentivos para a realização desses investimentos. Por fim, mais recentemente, tem ganhado força o argumento de que bancos 
públicos de desenvolvimento, ao ofertarem crédito de longo prazo, poderiam atuar como estabilizadores da atividade econômica ao manter a oferta de recursos mesmo em situações de instabilidade econômica, em que os agentes privados podem se sentir estimulados a diminuir a oferta de crédito $^{26}$.

Seguindo o raciocínio apresentado por Odedokun (1996), bancos públicos de desenvolvimento seriam relevantes desde que sua atuação não gerasse distorções ao funcionamento do mercado financeiro como um todo, que os aportes por elas recebidos (muitas vezes oriundos do próprio orçamento do governo) não representassem alocação ineficiente dos recursos e, por fim, que os tomadores utilizassem o financiamento de forma eficiente. Os resultados encontrados por Odedokun (1996) e Antunes, Cavalcanti e Villamil (2015), por exemplo, sugerem efeitos deletérios dos bancos de desenvolvimento sobre variáveis econômicas reais, como investimento, emprego e produto. Assim, ainda que existam razões relevantes para a existência e atuação dos bancos de desenvolvimento, não é consensual para a literatura que o resultado efetivo seja positivo.

Retomando o trabalho de Sapienza (2004), ainda existem outras duas visões sobre os bancos públicos. De acordo com a segunda, baseada na teoria de agência, ainda que tais instituições tenham como objetivo central minimizar as falhas do mercado de crédito, pode não ser possível gerar uma estrutura de incentivos tal que seus gestores se esforcem suficientemente de modo a atingir os objetivos almejados, alocando parte de seu esforço para fins alternativos e diminuindo, portanto, o eventual efeito positivo decorrente da atuação dos bancos públicos (inclusive os de desenvolvimento). De acordo com esta visão, tais instituições poderiam estar sujeitas à influência de interesses burocráticos de tal forma que o banco não necessariamente agiria com vistas a estabilizar e corrigir as falhas do mercado de crédito ou a financiar investimentos que gerassem externalidades positivas. Finalmente, a terceira visão levantada por Sapienza (2004) e também discutida por Shleifer e Vishny (1994) e Porta, Silanes e Shleifer (2002), entre outros, é denominada visão política: segundo esta, bancos públicos seriam geridos de tal forma a beneficiar grupos politicamente alinhados à instituição ou então seus próprios gestores, que nem sempre são indicados por critérios técnicos. Assim, a visão política entende que uma eventual máalocação de recursos por parte da instituição é consequência de ações que visem beneficiar grupos específicos, ao passo que a visão de agência entende que a má-alocação pode ser consequência de uma estrutura de incentivos inadequada tais que seus gestores não se esforcem devidamente de modo a atingir os objetivos da instituição.

O estudo realizado neste capítulo se aproxima da terceira visão teórica proposta Sapienza (2004) pois, conforme mencionado anteriormente, o objetivo é analisar em que medida o alinhamento partidário entre o governo federal, por um lado, e os governos estaduais e municipais, por outro, exerce efeito sobre a concessão de financiamento por meio do BNDES.

De fato, existem diversos trabalhos cujo objetivo se assemelha ao apresentado neste capítulo, sendo que algumas dessas referências analisam países específicos, como o próprio trabalho de Sapienza (2004), por exemplo. Analisando dados italianos entre 1991 e 1995,

26 Em linha com esse argumento, Micco e Panizza (2006), por exemplo, encontram evidências de que a provisão de crédito por bancos públicos é menos pró-cíclica do que a provisão realizada por bancos privados. 
seus resultados indicam que grandes empresas, que poderiam obter crédito junto ao mercado privado, são justamente aqueles beneficiadas pelos bancos públicos, em particular, com crédito a juros mais baixos comparativamente ao crédito concedido por bancos privados. Explorando o fato de que muitos gestores dos bancos públicos italianos são filiados a partidos políticos, a autora também encontra evidências que indicam que as condições de crédito são mais favoráveis às empresas situadas justamente nas regiões em que a agremiação política do gestor obteve maior suporte eleitoral. Khwaja e Mian (2005), por sua vez, encontram evidências que reforçam a percepção de que bancos públicos podem estar sujeitos a interesses políticos. Ao analisar dados de empresas paquistanesas, os resultados obtidos pelos autores sugerem que aquelas politicamente "conectadas" (empresas cujos diretores já disputaram algum tipo de eleição, ou seja, são membros de algum partido político) não só tomam mais crédito junto a bancos públicos, mas também apresentam maiores taxas de inadimplência. Por outro lado, os resultados obtidos pelos autores indicam que fatores políticos exercem efeito nulo sobre o crédito obtido por essas empresas junto a bancos privados.

Ainda na linha de estudos sobre países específicos, Cole (2009) analisa a oferta de crédito agrícola provido por bancos públicos indianos e encontra evidências de expansão em anos eleitorais, especialmente em distritos em que as eleições são mais acirradas (e onde, portanto, a necessidade deste tipo de suporte visando vencer a disputa é maior). Por fim, os resultados do autor indicam efeito nulo da expansão de crédito observada em anos eleitorais sobre a produção agrícola das áreas beneficiadas, reforçando portanto a percepção de mera manipulação oportunista envolvendo os bancos públicos. Resultados que reforçam esta percepção também são encontrados por Dinc (2005), que explora um painel contemplando informações ao nível dos bancos de diversos países e encontram evidências de aumento da oferta de crédito por parte dos bancos públicos em anos eleitorais, especialmente em economias emergentes. Esse resultado, contudo, não é confirmado pelos resultados encontrados por Micco e Panizza (2006): também explorando um painel de países com informações ao nível dos bancos, os autores encontram evidências fracas de expansão de crédito por parte dos bancos públicos em períodos eleitorais. Por fim, analisando o caso chinês, Li et al. (2008) encontram evidências de que empresas privadas cujos proprietários são filiados ao partido comunista apresentam mais facilidade para obtenção de crédito junto a bancos públicos e outras instituições governamentais.

Para o caso brasileiro, duas referências podem ser mencionadas. Carvalho (2014) analisa um painel de firmas brasileiras entre 1995 e 2005 e encontra evidências de que empresas elegíveis à financiamentos junto ao BNDES aumentam a quantidade de emprego em estados cujo governante é politicamente alinhado com o governo federal - esse aumento se dá especialmente nos períodos anteriores às eleições e nas localidades em que a competição eleitoral é mais acirrada. Esse comportamento por parte das firmas parece ser compensador, dado que o autor encontra evidências de que tais empresas são posteriormente beneficiadas com maiores créditos junto ao referido banco. Ademais, esse arranjo é tal que as firmas não aumentam seu emprego total: o autor encontra evidências de que as mesmas apenas reposicionam geograficamente suas plantas em direção às localidades cujo chefe do executivo é alinhado com o governo federal, com a consequente queda do emprego das regiões não alinhadas. O segundo estudo, por sua vez, tem objetivo bastante semelhante ao apresentado neste capítulo da tese: Leao, Mello e Ferraz (2013) analisam o 
efeito do alinhamento partidário entre governo municipal e governo federal sobre o montante de crédito concedido via bancos comerciais públicos federais, em especial, o Banco do Brasil (BB) e a Caixa Econômica Federal (CEF). Explorando um painel de municípios brasileiros entre 1997 e 2008, os autores encontram evidências de que a taxa de crescimento da oferta de crédito provida por tais instituições financeiras é maior em municípios politicamente alinhados com o governo federal comparativamente a municípios não alinhados. Em particular, esse efeito é verificado no crédito não-direcionado e no crédito destinado às pessoas jurídicas.

Tendo em vista a crescente literatura sobre os empréstimos concedidos pelo BNDES ao setor público e a literatura que discute o efeito de fatores políticos sobre a atuação de bancos públicos, este estudo procura trazer novos resultados ao unificar essas duas discussões. A próxima seção passa a discutir a metodologia empregada neste estudo.

\subsection{Procedimentos metodológicos}

O objetivo desta seção é descrever os procedimentos metodológicos empregados na realização deste estudo que, conforme mencionado anteriormente, tem como objetivo investigar se governos estaduais e municipais cujos chefes de executivo são alinhados politicamente com o governo federal recebem empréstimos de maior montante relativamente aos estados e municípios não alinhados, ou se esses empréstimos são tomados com melhores condições de devolução (menores taxas de juros e/ou maiores prazos de amortização e de carência, em particular).

São realizadas duas análises distintas. A primeira analisa os empréstimos tomados pelos governos municipais (prefeituras) junto ao BNDES, ao passo que a segunda analisa os empréstimos tomados pelos governos estaduais. Em linha com o objetivo do estudo, note que são considerados apenas os empréstimos tomados pela administração pública direta desses dois níveis de governo, não contemplado, portanto, outros tipos de financiamento (tomados por empresas privadas ou por sociedades de economia mista, por exemplo).

O BNDES, em seu sítio eletrônico, disponibiliza informações referentes aos financiamentos disponíveis aos governos estaduais e municipais brasileiros. Tais empréstimos são classificados em diretos ou indiretos, e automáticos ou não automáticos, além da separação entre programas, conforme apresentado em sequência ${ }^{27}$.

- Direta: operação realizada diretamente com o BNDES ou por meio de mandatário. Nesse tipo de operação, é necessário apresentar o pedido ao BNDES por meio da denominada Consulta Prévia, documento em que são descritas as características básicas do solicitante e do empreendimento para a análise do Banco. Para solicitar apoio direto ao BNDES, é necessário que o financiamento tenha valor superior a $\mathrm{R} \$ 20$ milhões, mas em alguns casos específicos é possível que o apoio direto a financiamentos tenha valor inferior a esse limite.

- Indireta: operações realizadas por meio de instituições financeiras, em que a análise do financiamento é feita pelas mesmas, que assumem o risco de não pagamento da

$\overline{27}$ Essas informações foram obtidas junto ao sítio eletrônico da própria instituição. 
operação. Por isso, a instituição pode aceitar ou não o pedido de crédito. É ela também que negocia com o cliente as condições do financiamento, como prazo de pagamento e garantias exigidas, respeitando algumas regras e limites definidos pelo BNDES. Existem duas modalidades de operação indireta:

- Automática: operação que não precisa passar por avaliação prévia do BNDES. O pedido é recebido e analisado pela instituição financeira credenciada, que aprova o crédito e, em seguida, solicita ao BNDES a homologação e liberação dos recursos. Fazem parte desta modalidade as operações de financiamento com valor até $\mathrm{R} \$ 20$ milhões.

- Não automática: operação indireta em que é necessário apresentar a Consulta Prévia, que é encaminhada ao BNDES pela instituição financeira credenciada para análise. Neste caso, as operações de financiamento são individualmente avaliadas e aprovadas pelo BNDES. O valor mínimo para esta forma de apoio é de $\mathrm{R} \$ 20$ milhões.

Neste estudo, serão analisados somente os empréstimos realizados por meio das modalidades Direta e Indireta Não Automática (doravante DINA), por duas razões: em primeiro lugar, dado o objetivo do estudo, parte-se da premissa de que um eventual efeito do alinhamento partidário sobre o financiamento concedido pelo BNDES é maior (ou, no limite, só é verificado) caso a solicitação seja avaliada diretamente pelo BNDES, e não somente pelos intermediários financeiros. Em segundo lugar, algumas informações relevantes para a realização deste estudo (em particular as condições do financiamento, como taxa de juros, por exemplo) só são disponibilizadas pelo BNDES para os financiamentos da modalidade DINA ${ }^{28}$.

Além dessas categorizações, há outra distinção quanto aos empréstimos providos pelo BNDES. Em particular, há uma modalidade denominada "Recursos não reembolsáveis" que, segundo o próprio BNDES, são concedidos para apoiar projetos específicos sem a exigência de devolução ao banco. Dado que não há a devolução do recurso por parte do tomador (neste estudo, os municípios e estados brasileiros), não há que se falar em prazo de amortização, prazo de carência nem taxa de juros para esse tipo específico de financiamento. Os recursos ditos "Reembolsáveis", por sua vez, devem ser devolvidos ao banco, com a negociação das condições para a devolução.

O problema a ser investigado neste capítulo pode ser genericamente representado pelas Equações 7, 8, 9 e 10, cujo objetivo é analisar se municípios ou estados alinhados com o governo federal tomam financiamento em volume maior ou sob condições mais favoráveis relativamente aos não alinhados (omitindo as variáveis de controle, para facilitar a interpretação):

$$
\text { Valor Financiamento }{ }_{i t}=\alpha+c_{i}+\beta . a_{i t}+\epsilon_{i t}
$$

28 Segundo o BNDES, há uma terceira modalidade denominada Mista, que são operações que combinam as formas direta e indireta não automática e ambas compartilham o risco da operação. As operações mistas geralmente ocorrem por sugestão do BNDES ou da instituição credenciada, isto é, não podem ser solicitadas pelo cliente. 


$$
\text { Prazo Amortização } i t=\alpha+c_{i}+\beta . a_{i t}+\epsilon_{i t}
$$

$$
\text { Prazo Carência }_{i t}=\alpha+c_{i}+\beta . a_{i t}+\epsilon_{i t}
$$

Em que o índice $i$ representa um determinado município ou estado, ao passo que o índice $t$ representa um determinado ano. As variáveis dependentes Valor Financiamento, Juros Financiamento, Prazo Amortização e Prazo Carência mensuram, respectivamente, o montante (em logaritmo natural), a taxa de juros (em \% a.a. ${ }^{29}$ ), o prazo de amortização e o prazo de carência (ambos mensurados em meses) do financiamento obtido junto ao BNDES. $\alpha$ representa a constante do modelo, $c_{i}$ representa o efeito específico de cada município ou estado e $\epsilon$ representa o termo de erro. $\beta$, por seu turno, representa o coeficiente associado à principal variável explorada neste estudo, qual seja, a variável dummy a que, de forma análoga ao Capítulo 2, assume o valor 1 caso o prefeito ou o governador sejam membros de um partido que tenha feito parte da coligação vencedora da eleição presidencial e 0 caso contrário. Desta forma, a variável $a$ representa o fato de um município ou estado estar ou não estar alinhado com o governo federal. Também a exemplo do Capítulo 2, são realizadas estimações adicionais nas quais a variável $a$ assume valor 1 não só caso o partido do prefeito ou do governador tenham feito parte da coligação vencedora das eleições presidenciais, mas também caso tenham ocupado algum ministério do governo federal ${ }^{30}$. Contudo, ainda que existam semelhanças, é importante deixar claro que neste capítulo explora-se o fato de um município ou estado estar alinhado ou não com o governo federal, diferentemente do Capítulo 2, em que se explorou o fato de um município estar alinhado com o governo estadual e/ou com o governo federal.

Em relação à variável dependente das Equações 7, 8, 9 e 10 esclarecem-se dois pontos: os dados disponibilizados pelo BNDES são tais que um município ou estado podem tomar diferentes financiamentos em um mesmo ano, sob condições de amortização diferentes: isto acontece, por exemplo, caso empréstimos distintos sejam realizados por meio de modalidades distintas ou para projetos distintos. Mais frequente na amostra, contudo, é o caso em que um mesmo empréstimo é decomposto em diferentes subcréditos, também sujeitos a diferentes taxas de juros em função de diferentes itens financiados. Além disto, há também a distinção entre recursos reembolsáveis, isto é, que devem ser devolvidos ao

29 Segundo o BNDES, as taxas de juros das operações diretas, modalidade que representa a maior parte dos financiamentos presentes na amostra, são definidas pela soma do custo financeiro, remuneração do BNDES e da taxa de risco de crédito. Para as operações indiretas, por sua vez, a taxa de juros é definida pela soma do custo financeiro, remuneração do BNDES, taxa de intermediação financeira e remuneração da instituição financeira credenciada.

30 Um esclarecimento importante diz respeito à mudança de partidos dos prefeitos. Na amostra explorada neste estudo, dado que houve mudança em apenas dois dos municípios contemplados com financiamento do BNDES, optou-se por não apresentar os resultados referentes a essa mudança dado que tendem a provocar mudanças marginais nos resultados. Assumindo não ter ocorrido mudança de partido dos prefeitos, 74 observações são referentes a municípios são alinhados com o governo federal, ao passo que 182 não são. Considerando as mudanças, 76 observações são referentes a municípios são alinhados, ao passo que 180 não são. 
BNDES, e não reembolsáveis, que não precisam ser devolvidos. Para que os dados pudessem ser organizados em formato de painel tal que a cada município ou estado estivesse associado apenas um empréstimo por ano, procedeu-se da seguinte forma: para os valores dos empréstimos, para cada tipo de empréstimo entre "Reembolsável" e "Não reembolsável" e para cada município ou estado, realizou-se a soma dos valores dos diferentes financiamentos tomados em um dado ano. Assim, dado que alguns financiamentos são do tipo "Não reembolsáveis" e outros do tipo "Reembolsável", a Equação 7 é estimada para duas amostras: uma em que constam todos os municípios (estados) beneficiados (caso em que a variável dependente é o total do valor tomado (independentemente do valor empréstimo ser do tipo "Não reembolsável" ou não) e outra em que constam somente os municípios (estados) que tomaram financiamentos do tipo "Reembolsável" (caso em que a variável dependente é o valor do financiamento exclusivamente desta modalidade). Já para a taxa de juros, para o prazo de amortização e para o prazo de carência, realizou-se a soma ponderada pelo valores de cada financiamento tomado em um dado ano somente para os recursos do tipo reembolsáveis dado que, conforme mencionado anteriormente, não há que se falar sobre essas variáveis para os empréstimos do tipo "Não reembolsável". Assim, as Equações 8, 9 e 10 são estimadas somente para os financiamentos do tipo "Reembolsável".

A título de ilustração, considere o município de Blumenau-SC, que no ano de 2004 tomou dois financiamentos do tipo "Reembolsável" junto ao BNDES, em montantes iguais a $\mathrm{R} \$ 2.445 .000,00$ e $\mathrm{R} \$ 4.178 .070,00^{31}$, respectivamente, com taxas de juros iguais a $3,5 \%$ e $2,5 \%$, respectivamente. O valor do financiamento considerado para este estudo é igual a $\mathrm{R} \$$ 6.623.070,00², que corresponde à soma simples dos valores dos empréstimos anteriormente mencionados, ao passo que a taxa de juros considerada neste estudo é igual à $2,87 \%$, que corresponde à soma das taxas de juros anteriormente mencionadas ponderadas pela participação de cada financiamento sobre o montante total tomado no ano

Uma preocupação natural quanto a este cálculo diz respeito à agregação de empréstimos com características distintas. Ressalta-se, contudo, que a maioria dos empréstimos apresenta características comuns. Dos 393 financiamentos (pré-agregação) tomados pelos estados entre 2002 e 2014, 335 têm como custo financeiro a TJLP e 45 são sem custo ${ }^{33}$, 350 são da área operacional infra-estrutura social, 358 são da forma de apoio direta e 35 indireta e 348 são da modalidade de apoio reembolsável e 45 não reembolsável. Por sua vez, dos 502 financiamentos (pré-agregação) tomados pelos municípios entre 2002 e 2012, 438 têm como custo financeiro a TJLP e 64 são sem custo $^{34}, 477$ têm como área operacional infra-estrutura social, 489 são da forma de apoio direta e 13 indireta e finalmente, 438 são da modalidade reembolsável e 64 não reembolsáveis.

As variáveis de controle consideradas neste estudo seguem a mesma motivação apresentada no Capítulo 2. O primeiro grupo, de natureza política, é composto pela fragmentação de votos ao executivo, calculada para cada município ou estado e para cada

31 Em valores da época.

32 Vide nota de rodapé anterior.

33 Isto é, são da modalidade de apoio não reembolsável. As demais têm como custo financeiro a SELIC e o IPCA, entre outros.

34 Vide nota de rodapé anterior. 
mandato, com base na fórmula Fragmentação de votos $=1-\sum_{j=1}^{J} v_{j}^{2}$, em que $v_{j}$ é a proporção de votos $\left(0<v_{j}<1\right)$ obtida por cada candidato j a prefeito ou governador, em cada eleição municipal ou estadual. Conforme mencionado no Capítulo 2, esta medida, que aumenta conforme a distribuição de votos entre os candidatos se torna mais homogênea, mensura o grau de competição política da eleição e pode ser entendido como proxy para a heterogeneidade da preferência dos eleitores de um dado município ou estado.

Por sua vez, o segundo grupo de variáveis de controle é composto pelos mesmos indicadores demográficos utilizados no Capítulo 2 desta tese, quais sejam, o número de habitantes ${ }^{35}$, a porcentagem de jovens e o grau de urbanização, que procuram mensurar o grau de necessidade de recursos públicos de uma determinada localidade. Por fim, as estimações incluem dois indicadores fiscais, quais sejam, as razões Dívida Consolidada Líquida / Receita Corrente Líquida (doravante DCL / RCL) e Despesa de Pessoal / Receita Corrente Líquida (doravante Pessoal / RCL), que mensuram o grau de endividamento e o grau de comprometimento do orçamento com gastos com pessoal do município ou estado. Em particular, as estimações contemplam a distância entre os limites estabelecidos pela Lei de Responsabilidade Fiscal $(\mathrm{LRF})^{36}$ e os valores observados em cada estado ou município, de tal forma que valores maiores representam maiores distâncias em relação ao limite de endividamento e ao limite de comprometimento do orçamento com folha de pagamento. Assim, a inclusão desses dois indicadores nas regressões permite testar a hipótese de que municípios e estados em situação fiscal mais confortável (em relação aos limites mencionados) estariam mais propensos a solicitar financiamento junto ao BNDES ou então, tomariam empréstimos de maior volume e/ou tomados sob melhores condições de amortização.

Em relação à fonte dos dados utilizados neste estudo, os indicadores demográficos foram obtidos junto ao IBGE, ao passo que as informações fiscais foram obtidos junto à STN. Finalmente, as informações políticas exploradas neste estudo foram obtidas junto ao TSE. Os dados referentes aos valores dos financiamentos concedidos pelo BNDES estão mensurados em $\mathrm{R} \$$ de 2014, deflacionados com base no IPCA do IBGE.

Em relação às estimações, são realizados dois exercícios distintos. No primeiro, dado que a solicitação do financiamento não é aleatória, mas sim uma decisão do próprio estado ou município, os resultados advindos de uma amostra que contemple somente as unidades beneficiadas estão muito provavelmente sujeitos ao problema de viés de seleção ${ }^{37}$. Assim, são estimadas regressões do tipo pooled Heckman, em que o primeiro estágio estima a probabilidade de um estado ou município solicitar financiamento junto ao BNDES, ao passo que o segundo analisa o montante recebido ou as variáveis que mensuram as condições do financiamento (taxa de juros e prazos de amortização e de carência), condicional à solicitação ter sido realizada (e atendida) pelo BNDES.

O segundo exercício, por sua vez, contempla estimações do tipo Regression Discontinuity Design ou RDD, cuja objetivo é comparar municípios (estados) alinhados com

35 Novamente, em logaritmo natural, para tornar os valores menos heterogêneos.

36 Segundo a qual, para os estados e municípios, o limite é igual 0,6 para a razão Pessoal / RCL. Já para a razão DCL / RCL, o limite é igual a 2 para estados e 1,2 para municípios.

37 Infelizmente, não há informações referentes a projetos submetidos ao BNDES e que foram rejeitados. Assim, os dados explorados neste estudo são referentes apenas àqueles estados e municípios que solicitaram o financiamento e que foram efetivamente atendidos. 
o governo federal cujo prefeito/governador tenha vencido a eleição por uma pequena margem de vitória, por um lado, e municípios (estados) não alinhados com o governo federal cujo prefeito/governador tenha vencido a eleição por uma pequena margem de vitória, por outro. Em particular, esta variável, intitulada Margem de vitória, é definida como a diferença da proporção de votos obtida pelo primeiro colocado (prefeito ou governador eleito) e pelo segundo candidato mais votados no turno em que a eleição foi decidida em cada município ou estado ${ }^{38}$ e assume valores positivos para municípios (estados) alinhados com o governo federal e negativos para municípios (estados) não alinhados com o governo federal. Segundo Imbens e Lemieux (2008) e Klaauw (2008), a comparação de unidades próximas a esse limiar (ou threshold, que neste estudo se refere à margem de vitória próxima de zero) pode ser vista como um quase-experimento, isto é, o fato de um município ou estado estar ou não estar alinhado com o governo federal pode ser tomado como aleatório, minimizando portanto o efeito de outros fatores que possam enviesar os resultados ${ }^{39}$.

Tanto no caso dos estados como no caso dos municípios, são adotadas duas abordagens para a análise RDD. Na primeira, paramétrica, são estimadas regressões do tipo pooled OLS de ajuste polinomial global que contemplam como regressores, além da dummy de alinhamento e as variáveis de controle, a variável Margem de vitória, que assume valores lineares, quadráticos e cúbicos, e suas respectivas interações com a dummy de alinhamento ${ }^{40}$. Essas regressões podem ser representadas pela Equação $11^{41}$, em que $y_{i t}$ se refere ao montante do financiamento ou às variáveis que mensuram as condições do financiamento (taxas de juros, prazo de amortização e prazo de carência); $a_{i t}$ se refere à dummy de alinhamento e $m v_{i t}$ se refere à margem de vitória que, conforme mencionado anteriormente, assume valores positivos para prefeitos (governadores) alinhados com o governo federal e valores negativos, por sua vez, para prefeitos (governadores) não alinhados ${ }^{42}$.

$$
y_{i t}=\alpha+\beta \cdot a_{i t}+\gamma_{1} \cdot m v_{i t}+\psi_{1} \cdot m v_{i t} \cdot a_{i t}+\gamma_{2} \cdot m v_{i t}^{2}+\psi_{2} \cdot m v_{i t}^{2} \cdot a_{i t}+\gamma_{3} \cdot m v_{i t}^{3}+\psi_{3} \cdot m v_{i t}^{3} \cdot a_{i t}+\epsilon_{i t}
$$

Por sua vez, na segunda abordagem das estimações RDD, não paramétrica, são estimadas funções de ajuste polinomial local para cada um dos grupos de municípios (estados) alinhados e não alinhados, sendo que a diferença entre esses dois grupos em torno da margem de vitória igual a zero (que define se o município (estado) é alinhado com o governo federal ou não) pode ser vista como a medida do eventual efeito do ali-

38 Por exemplo, se em um dado município ou estado a eleição para prefeito ou governador foi decidida em primeiro turno, utiliza-se a diferença registrada neste turno, e caso a eleição tenha sido decidida somente em segundo turno, utiliza-se a diferença registrada neste turno específico, ignorando-se portanto a diferença registrada no primeiro turno.

39 Note que, dada a natureza do problema proposto, a amostra é composta apenas por candidatos efetivamente eleitos dado que os não eleitos não assumem o governo e, portanto, não podem solicitar financiamento junto ao BNDES para as localidades para as quais concorreram.

40 Os coeficientes associados à margem de vitória e suas interações com a dummy de alinhamento são omitidos das tabelas com vistas a facilitar a exposição dos resultados.

41 Novamente, omite-se as variáveis de controle, para facilitar a exposição, muito embora as mesmas tenham sido incluídas nas estimações.

42 Tanto as estimações realizadas por meio do método de Heckman como as estimações RDD paramétricas incluem dummies de ano visando controlar as estimações por eventos específicos de cada ano da amostra. 
nhamento. Neste caso, as funções de ajuste polinomial são obtidas via uso de polinômios locais de primeira ordem (lineares) e kernel do tipo Triangular. Assim como realizado por Arvate, Barbosa e Fuzitani (2016), entre outros, são empregados três procedimentos para definição da banda ${ }^{43}$ (bandwidth), conforme sugeridos por Calonico, Cattaneo e Titiunik (2014) (CCT), Imbens e Kalyanaraman (2012) (IK) e Ludwig e Miller (2007) (CV), com intervalos de confiança robustos conforme proposto por Calonico, Cattaneo e Titiunik $(2014)^{44}$.

No caso dos municípios, os dados disponíveis permitiram constituir uma amostra que contempla os anos entre 2002 e 2012. Conforme apresentado na Tabela 12, que apresenta o número de municípios que tomaram financiamentos junto ao BNDES por unidade da federação (UF) e ano da amostra, é possível notar que alguns estados não apresentam municípios tomadores de recursos, como Alagoas, Goiás, Rio Grande do Norte, Roraima, Sergipe e Tocantins. Por outro lado, os estados de São Paulo, Santa Catarina e Minas Gerais apresentam o maior número de municípios tomadores. Nota-se também que o ano de 2004 foi o que registrou o maior número de financiamentos (54 municípios), sendo seguido pelo ano de 2007 (40 municípios) e 2008 (30 municípios). Já o ano de 2011 registra o menor número de financiamentos (11 municípios). No total, a amostra explorada neste estudo contempla 256 financiamentos (pós-agregação).

Tabela 12 - Quantidade de municípios contemplados com financiamentos do BNDES, por unidade da federação e ano

\begin{tabular}{ccccccccccccc}
\hline UF & 2002 & 2003 & 2004 & 2005 & 2006 & 2007 & 2008 & 2009 & 2010 & 2011 & 2012 & Total \\
\hline AC & 0 & 0 & 1 & 0 & 0 & 2 & 0 & 0 & 0 & 1 & 0 & 4 \\
AL & 0 & 0 & 0 & 0 & 0 & 0 & 0 & 0 & 0 & 0 & 0 & 0 \\
AM & 0 & 0 & 0 & 0 & 0 & 0 & 0 & 1 & 0 & 0 & 0 & 1 \\
AP & 0 & 0 & 1 & 0 & 0 & 0 & 0 & 0 & 0 & 0 & 0 & 1 \\
BA & 0 & 0 & 3 & 1 & 1 & 0 & 0 & 0 & 0 & 0 & 0 & 5 \\
CE & 0 & 2 & 2 & 0 & 4 & 4 & 2 & 2 & 2 & 1 & 0 & 19 \\
ES & 0 & 0 & 3 & 1 & 1 & 1 & 4 & 0 & 1 & 0 & 1 & 12 \\
GO & 0 & 0 & 0 & 0 & 0 & 0 & 0 & 0 & 0 & 0 & 0 & 0 \\
MA & 0 & 0 & 0 & 0 & 0 & 0 & 0 & 0 & 1 & 0 & 0 & 1 \\
MG & 2 & 1 & 3 & 0 & 2 & 8 & 5 & 1 & 1 & 0 & 0 & 23 \\
MS & 1 & 0 & 0 & 0 & 0 & 1 & 0 & 0 & 0 & 0 & 0 & 2 \\
MT & 0 & 1 & 5 & 0 & 1 & 3 & 4 & 0 & 1 & 4 & 0 & 19 \\
PA & 1 & 0 & 1 & 0 & 0 & 1 & 0 & 0 & 1 & 0 & 2 & 6 \\
PB & 1 & 0 & 0 & 0 & 2 & 1 & 0 & 0 & 0 & 0 & 0 & 4 \\
PE & 1 & 0 & 2 & 2 & 0 & 0 & 2 & 1 & 0 & 0 & 0 & 8 \\
PI & 0 & 1 & 0 & 0 & 0 & 0 & 1 & 0 & 0 & 0 & 0 & 2 \\
PR & 0 & 1 & 7 & 0 & 0 & 4 & 6 & 0 & 0 & 0 & 1 & 19 \\
RJ & 0 & 2 & 2 & 0 & 2 & 1 & 1 & 1 & 1 & 2 & 0 & 12 \\
RN & 0 & 0 & 0 & 0 & 0 & 0 & 0 & 0 & 0 & 0 & 0 & 0 \\
RO & 0 & 0 & 0 & 0 & 1 & 0 & 0 & 0 & 0 & 0 & 1 & 2 \\
RR & 0 & 0 & 0 & 0 & 0 & 0 & 0 & 0 & 0 & 0 & 0 & 0 \\
RS & 1 & 1 & 5 & 3 & 2 & 2 & 1 & 0 & 2 & 2 & 2 & 21 \\
SC & 1 & 5 & 3 & 2 & 3 & 2 & 2 & 3 & 2 & 0 & 2 & 25 \\
SE & 0 & 0 & 0 & 0 & 0 & 0 & 0 & 0 & 0 & 0 & 0 & 0 \\
SP & 5 & 7 & 16 & 7 & 9 & 10 & 2 & 3 & 4 & 1 & 6 & 70 \\
TO & 0 & 0 & 0 & 0 & 0 & 0 & 0 & 0 & 0 & 0 & 0 & 0 \\
Total & 13 & 21 & 54 & 16 & 28 & 40 & 30 & 12 & 16 & 11 & 15 & 256 \\
\hline
\end{tabular}

Fonte: elaboração própria

\footnotetext{
43 Intervalo ao redor do threshold.

44 Esses métodos podem ser vistos como mais apropriados do que o método paramétrico dado que definem bandas ótimas (optimal bandwidth) ao redor do threshold.
} 
No caso dos estados, por sua vez, os dados disponíveis permitiram constituir uma amostra que contempla os anos entre 2002 e 2014. Conforme apresentado na Tabela 13, que apresenta quais estados tomaram financiamentos por ano da amostra, é possível notar que todas as unidades da federação foram contempladas com empréstimos concedidos pelo BNDES ao menos uma vez durante o período em questão, exceto o Distrito Federal. Notase, entre outros, um crescimento bastante significativo do número de empréstimos a partir de 2008 , sendo que 2010 foi o ano que apresentou o maior número de estados beneficiados (25 empréstimos), seguido pelos anos de 2009 (22 empréstimos) e 2012 (21 empréstimos). Os estados do Acre, Ceará, Rio de Janeiro, Pará, Pernambuco e São Paulo figuram entre os tomadores mais frequentes ao longo dos anos em questão. No total, a amostra explorada neste estudo contempla 136 financiamentos (pós-agregação).

Tabela 13 - Estados contemplados com financiamentos do BNDES, por unidade da federação e ano

\begin{tabular}{|c|c|c|c|c|c|c|c|c|c|c|c|c|c|c|}
\hline UF & 2002 & 2003 & 2004 & 2005 & 2006 & 2007 & 2008 & 2009 & 2010 & 2011 & 2012 & 2013 & 2014 & Total \\
\hline $\mathrm{AC}$ & Sim & - & - & Sim & - & - & Sim & Sim & Sim & Sim & Sim & $\mathrm{Sim}$ & Sim & 9 \\
\hline $\mathrm{AL}$ & - & - & - & - & - & - & - & Sim & Sim & - & Sim & Sim & - & 4 \\
\hline AM & - & - & - & - & - & - & Sim & Sim & Sim & - & Sim & Sim & Sim & 6 \\
\hline $\mathrm{AP}$ & - & - & - & - & - & - & - & Sim & Sim & - & - & Sim & Sim & 4 \\
\hline BA & - & - & Sim & - & - & - & - & Sim & Sim & - & - & Sim & - & 4 \\
\hline $\mathrm{CE}$ & Sim & - & - & Sim & Sim & - & Sim & Sim & Sim & - & Sim & Sim & Sim & 9 \\
\hline DF & - & - & - & - & - & - & - & - & - & - & - & - & - & 0 \\
\hline $\mathrm{ES}$ & - & - & - & Sim & - & - & - & Sim & Sim & - & Sim & - & - & 4 \\
\hline GO & - & - & - & - & - & - & - & - & Sim & - & Sim & Sim & - & 3 \\
\hline MA & - & - & Sim & - & - & - & - & Sim & Sim & - & Sim & Sim & - & 5 \\
\hline MG & - & - & - & Sim & - & - & - & Sim & Sim & - & Sim & - & - & 4 \\
\hline MS & - & - & - & - & - & - & Sim & Sim & Sim & - & Sim & Sim & - & 5 \\
\hline MT & - & - & - & Sim & - & - & & Sim & Sim & - & Sim & - & Sim & 5 \\
\hline $\mathrm{PA}$ & - & - & - & Sim & Sim & Sim & Sim & Sim & Sim & - & Sim & Sim & Sim & 9 \\
\hline $\mathrm{PB}$ & - & - & - & - & - & - & Sim & Sim & Sim & - & Sim & Sim & - & 5 \\
\hline $\mathrm{PE}$ & - & - & - & - & Sim & - & Sim & Sim & Sim & Sim & Sim & Sim & Sim & 8 \\
\hline PI & - & - & - & - & Sim & - & - & Sim & Sim & - & Sim & - & - & 4 \\
\hline $\mathrm{PR}$ & - & - & - & - & - & - & - & - & - & - & Sim & - & Sim & 2 \\
\hline RJ & Sim & - & - & - & Sim & - & Sim & Sim & Sim & Sim & Sim & Sim & Sim & 9 \\
\hline RN & - & - & - & Sim & - & - & - & Sim & Sim & & - & Sim & - & 4 \\
\hline $\mathrm{RO}$ & - & - & - & - & - & - & - & - & Sim & Sim & Sim & - & Sim & 4 \\
\hline $\mathrm{RR}$ & - & - & - & - & - & - & - & Sim & Sim & - & - & - & - & 2 \\
\hline $\mathrm{RS}$ & - & - & - & - & - & - & - & - & Sim & Sim & Sim & Sim & Sim & 5 \\
\hline $\mathrm{SC}$ & - & - & - & - & - & - & Sim & Sim & Sim & Sim & Sim & Sim & - & 6 \\
\hline SE & - & - & - & - & - & - & Sim & Sim & Sim & Sim & - & Sim & - & 5 \\
\hline SP & Sim & - & - & - & - & - & Sim & Sim & Sim & - & Sim & Sim & Sim & 7 \\
\hline TO & - & - & - & - & - & - & - & Sim & Sim & - & Sim & Sim & - & 4 \\
\hline Total & 4 & 0 & 2 & 7 & 5 & 1 & 11 & 22 & 25 & 7 & 21 & 19 & 12 & 136 \\
\hline
\end{tabular}

Fonte: elaboração própria

De acordo as estatísticas descritivas apresentadas na Tabela 15, os valores apresentados no Painel A indicam que municípios alinhados recebem, em média, financiamentos de maior montante (tanto para empréstimos totais como somente para empréstimos do tipo reembolsável), sujeitos à menores taxas de juros e com maiores prazos de amortização relativamente aos não alinhados, qualquer que seja a medida de alinhamento com o governo federal. Os prazos de carência parecem ser, contudo, relativamente maiores para municípios não alinhados. No caso dos estados (Painel B), a exemplo do caso dos municípios, os valores também sugerem que estados alinhados com o governo federal tomam empréstimos de maior montante junto ao BNDES qualquer que seja o tipo de emprés- 
Tabela 14 - Quantidade de municípios e estados contemplados com financiamentos do BNDES, por ano e tipo de alinhamento

\begin{tabular}{|c|c|c|c|c|c|c|}
\hline \multicolumn{7}{|c|}{ Painel A: Municípios } \\
\hline & \multicolumn{3}{|c|}{ Coligação presidencial } & \multicolumn{3}{|c|}{ Coligação ou ministros } \\
\hline & Não alinhado & Alinhado & Total & Não alinhado & Alinhado & Total \\
\hline 2002 & 8 & 5 & 13 & 6 & 7 & 13 \\
\hline 2003 & 18 & 3 & 21 & 15 & 6 & 21 \\
\hline 2004 & 39 & 15 & 54 & 21 & 33 & 54 \\
\hline 2005 & 14 & 2 & 16 & 5 & 11 & 16 \\
\hline 2006 & 23 & 5 & 28 & 7 & 21 & 28 \\
\hline 2007 & 28 & 12 & 40 & 16 & 24 & 40 \\
\hline 2008 & 25 & 5 & 30 & 12 & 18 & 30 \\
\hline 2009 & 9 & 3 & 12 & 4 & 8 & 12 \\
\hline 2010 & 10 & 6 & 16 & 4 & 12 & 16 \\
\hline 2011 & 3 & 8 & 11 & 3 & 8 & 11 \\
\hline 2012 & 5 & 10 & 15 & 5 & 10 & 15 \\
\hline \multicolumn{7}{|c|}{ Painel B: Estados } \\
\hline & \multicolumn{3}{|c|}{ Coligação presidencial } & \multicolumn{3}{|c|}{ Coligação ou ministros } \\
\hline & Não alinhado & Alinhado & Total & Não alinhado & Alinhado & Total \\
\hline 2002 & 2 & 2 & 4 & 2 & 2 & 4 \\
\hline 2003 & 0 & 0 & 0 & 0 & 0 & 0 \\
\hline 2004 & 2 & 0 & 2 & 2 & 0 & 2 \\
\hline 2005 & 6 & 1 & 7 & 4 & 3 & 7 \\
\hline 2006 & 4 & 1 & 5 & 2 & 3 & 5 \\
\hline 2007 & 0 & 1 & 1 & 0 & 1 & 1 \\
\hline 2008 & 8 & 3 & 11 & 2 & 9 & 11 \\
\hline 2009 & 17 & 5 & 22 & 6 & 16 & 22 \\
\hline 2010 & 20 & 5 & 25 & 8 & 17 & 25 \\
\hline 2011 & 1 & 6 & 7 & 1 & 6 & 7 \\
\hline 2012 & 9 & 12 & 21 & 9 & 12 & 21 \\
\hline 2013 & 8 & 11 & 19 & 8 & 11 & 19 \\
\hline 2014 & 4 & 8 & 12 & 4 & 8 & 12 \\
\hline
\end{tabular}

Fonte: elaboração própria

Notas: a contagem apresentada nesta tabela refere-se somente aos municípios (estados) que efetivamente receberam financiamento do BNDES.

timo (total ou somente reembolsável) e qualquer que seja a medida de alinhamento com o governo federal. As taxas de juros, por sua vez, parecem menores para estados alinhados para as duas medidas de alinhamento. Contudo, essas constatações preliminares devem ser vistas com cautela dado que são apenas estatísticas descritivas simples.

\subsection{Resultados}

Esta seção do capítulo apresenta os resultados das estimações conforme descritas na seção anterior, separadas em duas subseções: uma delas contemplando os resultados para os municípios e outra, os resultados para os estados. Nas tabelas em que são apresentados os resultados das estimações, os valores entre colchetes se referem ao erro-padrão dos coeficientes $^{45}$, ao passo que asteriscos denotam significância estatística aos níveis de ${ }^{*}=$ $10 \%,{ }^{* *}=5 \% \mathrm{e}^{* * *}=1 \%$, respectivamente.

\footnotetext{
$\overline{45}$ Para os resultados das estimações RDD paramétricas, em que são estimadas regressões do tipo pooled OLS, os erros-padrão foram calculados via clustering por município (no caso da análise dos municípios) e por estado (no caso do estudo para os estados).
} 
Tabela 15 - Estatísticas descritivas

\begin{tabular}{|c|c|c|c|c|c|c|}
\hline \multicolumn{7}{|c|}{ Painel A: Municípios } \\
\hline & & & \multicolumn{2}{|c|}{ Coligação presidencial } & \multicolumn{2}{|c|}{ Coligação ou ministros } \\
\hline & & & Não alinhado & Alinhado & Não alinhado & Alinhado \\
\hline Total & Valor do financiamento & $\begin{array}{c}\text { Média } \\
\text { Desvio-padrão } \\
\text { Observações }\end{array}$ & $\begin{array}{r}15,07 \\
1,92 \\
182\end{array}$ & $\begin{array}{r}15,85 \\
1,66 \\
74\end{array}$ & $\begin{array}{r}15,19 \\
1,86 \\
98\end{array}$ & $\begin{array}{r}15,36 \\
1,89 \\
158\end{array}$ \\
\hline Reembolsável & $\begin{array}{l}\text { Valor do financiamento } \\
\text { Taxa de juros }\end{array}$ & $\begin{array}{c}\text { Média } \\
\text { Desvio-padrão } \\
\text { Observações } \\
\text { Média } \\
\text { Desvio-padrão } \\
\text { Observações } \\
\text { Média } \\
\text { Desvio-padrão } \\
\text { Observações } \\
\text { Média } \\
\text { Desvio-padrão } \\
\text { Observações }\end{array}$ & $\begin{array}{r}15,17 \\
1,92 \\
162 \\
2,37 \\
0,64 \\
162 \\
78,00 \\
17,71 \\
162 \\
26,67 \\
6,99 \\
162\end{array}$ & $\begin{array}{r}15,96 \\
1,70 \\
65 \\
2,26 \\
0,47 \\
65 \\
79,35 \\
13,93 \\
65 \\
25,12 \\
4,81 \\
65\end{array}$ & $\begin{array}{r}15,35 \\
1,86 \\
84 \\
2,46 \\
0,69 \\
84 \\
77,19 \\
11,66 \\
84 \\
25,54 \\
8,39 \\
84\end{array}$ & $\begin{array}{r}15,42 \\
1,92 \\
143 \\
2,27 \\
0,52 \\
143 \\
79,10 \\
19,05 \\
143 \\
25,46 \\
4,89 \\
143\end{array}$ \\
\hline \multicolumn{7}{|c|}{ Painel B: Estados } \\
\hline & & & \multicolumn{2}{|c|}{ Coligação presidencial } & \multicolumn{2}{|c|}{ Coligação ou ministros } \\
\hline & & & Não alinhado & Alinhado & Não alinhado & Alinhado \\
\hline Total & Valor do financiamento & $\begin{array}{c}\text { Média } \\
\text { Desvio-padrão } \\
\text { Observações }\end{array}$ & $\begin{array}{r}18,93 \\
1,78 \\
81\end{array}$ & $\begin{array}{r}19,53 \\
1,75 \\
55\end{array}$ & $\begin{array}{r}18,74 \\
2,08 \\
48\end{array}$ & $\begin{array}{r}19,41 \\
1,56 \\
88\end{array}$ \\
\hline Reembolsável & Prazo de amortização & $\begin{array}{c}\text { Média } \\
\text { Desvio-padrão } \\
\text { Observações } \\
\text { Média } \\
\text { Desvio-padrão } \\
\text { Observações } \\
\text { Média } \\
\text { Desvio-padrão } \\
\text { Observações } \\
\text { Média } \\
\text { Desvio-padrão } \\
\text { Observacões }\end{array}$ & $\begin{array}{r}19,40 \\
1,35 \\
69 \\
2,13 \\
0,85 \\
69 \\
114,56 \\
45,37 \\
69 \\
28,32 \\
14,22 \\
69\end{array}$ & $\begin{array}{r}20,16 \\
1,06 \\
45 \\
1,80 \\
0,82 \\
45 \\
140,33 \\
62,04 \\
45 \\
29,91 \\
10,00 \\
45\end{array}$ & $\begin{array}{r}19,58 \\
1,48 \\
36 \\
2,09 \\
0,97 \\
36 \\
131,24 \\
55,11 \\
36 \\
29,62 \\
17,74 \\
36\end{array}$ & $\begin{array}{r}19,75 \\
1,21 \\
78 \\
1,96 \\
0,79 \\
78 \\
121,73 \\
53,32 \\
78 \\
28,64 \\
10,16 \\
78\end{array}$ \\
\hline
\end{tabular}

Fonte: elaboração própria

Notas: Valor do financiamento em logaritmo natural; Taxa de juros em \% a.a.; Prazo de amortização e prazo de carência em meses.

\subsubsection{Análise dos municípios}

\subsubsection{Método de viés de seleção}

As Tabelas 16 e 17 apresentam o primeiro conjunto de resultados das estimações para os municípios, obtidos por meio de equações do tipo pooled Heckman, por meio das quais é possível analisar o efeito do alinhamento partidário entre prefeitos municipais e o governo federal sobre o valor do financiamento (separadamente para financiamento total e para somente financiamento do tipo reembolsável) e sobre as condições (taxa de juros, prazo de amortização e prazo de carência dos financiamentos) dos empréstimos do tipo reembolsável. A primeira dessas duas tabelas apresenta os resultados referentes ao alinhamento com os partidos da coligação, ao passo que a segunda apresenta os resultados referentes ao alinhamento com os partidos da coligação e/ou com os partidos dos ministros ${ }^{46}$.

$\overline{46}$ Ressalta-se que além das dummies de ano, as estimações também contemplam dummies de unidade da federação. 
De acordo com os resultados, o efeito do alinhamento parece exercer pouco efeito sobre o financiamento obtido pelas prefeituras junto ao BNDES. Mesmo controlando as estimações pelo possível viés de seletividade amostral, os coeficientes associados à dummy de alinhamento são estatisticamente nulos, ou seja, sugerem que o efeito do alinhamento parece ser nulo tanto sobre o montante do financiamento (seja ele total ou do tipo reembolsável) como sobre as suas condições de devolução, qualquer que seja a medida de alinhamento com o governo federal.

Muito embora esses resultados sugiram um efeito nulo do alinhamento sobre o financiamento ou sobre as condições em que esses são tomados pelos municípios, uma análise mais geral sugere fatores importantes sobre a decisão dos municípios em solicitar recursos junto ao BNDES, isto é, sobre o primeiro estágio. Em primeiro lugar, parece haver um efeito positivo do alinhamento sobre a probabilidade de solicitação de recursos junto ao banco, isto é, localidades cujo chefe do executivo são alinhados com o governo federal são mais propensas a solicitar financiamento junto ao BNDES, seja ele especificamente do tipo reembolsável ou total, qualquer que seja a medida de alinhamento.

Note também que quanto mais distante a razão DCL/RCL do limite estabelecido pela LRF, isto é, quanto maior a "folga" de endividamento do município, maior a probabilidade de solicitação dos empréstimos. Muito embora o coeficiente da razão Pessoal/RCL seja estatisticamente nulo, o resultado referente ao indicador de endividamento sugere, portanto, que a situação fiscal dos municípios é fator relevante sobre a decisão de solicitação (por parte do município) e/ou a decisão de aprovação (por parte do banco) deste tipo de financiamento. Segundo os resultados, municípios mais populosos também apresentam maior probabilidade de solicitação de recursos junto ao BNDES, o que pode ser explicado pela hipótese de que municípios maiores são justamente os que mais demandam recursos para o investimento em infra-estrutura comparativamente a municípios de menor porte.

\subsubsection{Método RDD}

Os resultados apresentados na Tabela 18, por sua vez, foram obtidos por meio de regressões do tipo RDD via pooled OLS. Nessas regressões, conforme mencionado anteriormente, para cada variável dependente e para cada uma das duas medidas de alinhamento (apresentadas separadamente nos Painéis A e B), são estimadas funções em que a variável Margem de vitória é incluída como regressor assumindo valores lineares, quadráticos e cúbicos, além da inclusão da interação destes valores com a dummy de alinhamento $^{47,48}$.

Os resultados obtidos parecem confirmar aqueles apresentados nas Tabelas 16 e 17. $\mathrm{O}$ alinhamento parece exercer efeito estatisticamente nulo sobre o montante de financiamento obtido, dado que os coeficientes referentes à dummy de alinhamento são estatisticamente nulos qualquer que seja a especificação (linear, quadrática ou cúbica), qualquer que seja a medida de alinhamento, seja ele total ou especificamente do tipo reembolsável. O efeito do alinhamento também parece ser nulo sobre as condições do financiamento dado

47 Para facilitar a exposição dos resultados, os coeficientes referentes à margem de vitória (linear, quadrática e cúbica) e sua interações com a dummy de alinhamento são omitidos da Tabela 22.

48 Também foram incluídas as variáveis de controle, além de dummies de ano e dummies de unidade da federação. 
Tabela 16 - Alinhamento partidário e financiamento do BNDES aos municípios - viés de seleção - alinhamento com partidos da coligação presidencial

\begin{tabular}{|c|c|c|c|c|c|}
\hline \multirow[b]{2}{*}{$\begin{array}{c}\text { Coeficiente } \\
{[\text { Erro-padrão] }}\end{array}$} & \multicolumn{2}{|l|}{ Total } & \multicolumn{2}{|c|}{ Reembolsável } & \multirow[b]{2}{*}{$\begin{array}{l}\text { Prazo de } \\
\text { carência }\end{array}$} \\
\hline & $\begin{array}{c}\text { Valor do } \\
\text { financiamento }\end{array}$ & $\begin{array}{c}\text { Valor do } \\
\text { financiamento }\end{array}$ & $\begin{array}{l}\text { Taxa de } \\
\text { juros }\end{array}$ & $\begin{array}{c}\text { Prazo de } \\
\text { amortização }\end{array}$ & \\
\hline \multicolumn{6}{|c|}{ Segundo estágio } \\
\hline Alinhamento & $\begin{array}{l}-0,30 \\
{[0,52]}\end{array}$ & $\begin{array}{l}-0,01 \\
{[0,40]}\end{array}$ & $\begin{array}{l}-0,16 \\
{[0,23]}\end{array}$ & $\begin{array}{l}-5,13 \\
{[7,43]}\end{array}$ & $\begin{array}{c}0,75 \\
{[5,29]}\end{array}$ \\
\hline \multirow[t]{2}{*}{ Fragmentação } & $-0,67$ & $-1,31$ & $-0,12$ & 6,60 & $-11,45$ \\
\hline & {$[1,07]$} & {$[0,82]$} & {$[0,45]$} & {$[14,91]$} & {$[10,68]$} \\
\hline \multirow[t]{2}{*}{ DCL/RCL } & $-1,01$ & 0,75 & 0,06 & $-14,09$ & 7,95 \\
\hline & {$[1,50]$} & {$[1,00]$} & {$[0,58]$} & {$[18,53]$} & {$[13,07]$} \\
\hline \multirow[t]{2}{*}{ Pessoal/RCL } & 2,37 & 0,89 & 0,57 & 11,43 & $-0,50$ \\
\hline & {$[1,65]$} & {$[1,11]$} & {$[0,59]$} & {$[20,12]$} & {$[14,69]$} \\
\hline \multirow[t]{2}{*}{ Jovens } & 6,76 & $-7,45$ & $-2,56$ & 54,41 & $-104,66$ \\
\hline & {$[14,35]$} & {$[9,65]$} & {$[5,48]$} & {$[177,73]$} & {$[125,95]$} \\
\hline \multirow[t]{2}{*}{ Urbanização } & $-0,85$ & 1,28 & $-0,21$ & $-9,22$ & 9,42 \\
\hline & {$[1,82]$} & {$[1,61]$} & {$[0,93]$} & {$[29,79]$} & {$[20,89]$} \\
\hline \multirow{2}{*}{ População } & $-0,20$ & 1,84 & 0,14 & $-5,71$ & 11,42 \\
\hline & {$[1,71]$} & {$[1,16]$} & {$[0,68]$} & {$[21,51]$} & {$[15,06]$} \\
\hline \multirow{2}{*}{ Constante } & 23,78 & $-8,29$ & 2,07 & 202,67 & $-133,96$ \\
\hline & {$[27,04]$} & {$[18,78]$} & {$[11,01]$} & {$[348,67]$} & {$[243,55]$} \\
\hline Dummies de ano & Sim & Sim & Sim & Sim & Sim \\
\hline Dummies de UF & Sim & Sim & Sim & Sim & Sim \\
\hline \multicolumn{6}{|c|}{ Primeiro estágio } \\
\hline \multirow[t]{2}{*}{ Alinhamento } & $0,12^{*}$ & $0,14^{* *}$ & $0,14^{* *}$ & $0,14^{* *}$ & $0,14^{* *}$ \\
\hline & {$[0,07]$} & {$[0,07]$} & {$[0,07]$} & {$[0,07]$} & {$[0,07]$} \\
\hline \multirow[t]{2}{*}{ Fragmentação } & $-0,20$ & $-0,26$ & $-0,26$ & $-0,26$ & $-0,26$ \\
\hline & {$[0,20]$} & {$[0,20]$} & {$[0,20]$} & {$[0,20]$} & {$[0,20]$} \\
\hline \multirow[t]{2}{*}{ DCL/RCL } & $0,36^{* * *}$ & $0,34^{* * *}$ & $0,34^{* * * *}$ & $0,34^{* * *}$ & $0,34^{* * *}$ \\
\hline & {$[0,11]$} & {$[0,11]$} & {$[0,11]$} & {$[0,11]$} & {$[0,11]$} \\
\hline \multirow[t]{2}{*}{ Pessoal/RCL } & $-0,01$ & $-0,01$ & $-0,01$ & $-0,01$ & $-0,01$ \\
\hline & {$[0,37]$} & {$[0,40]$} & {$[0,40]$} & {$[0,40]$} & {$[0,40]$} \\
\hline \multirow[t]{2}{*}{ Jovens } & $-3,66^{* * *}$ & $-3,55^{* * *}$ & $-3,55^{* * *}$ & $-3,55^{* * *}$ & $-3,55^{* * * *}$ \\
\hline & {$[1,12]$} & {$[1,17]$} & {$[1,17]$} & {$[1,17]$} & {$[1,17]$} \\
\hline Urbanização & 0,36 & $0,51^{* *}$ & $0,51^{* *}$ & $0,51^{* *}$ & $0,51^{* *}$ \\
\hline \multirow{2}{*}{ População } & $0,45 * * *$ & $\begin{array}{l}{[0,25]} \\
0,43^{* * *}\end{array}$ & $\begin{array}{l}{[0,25]} \\
0.43 * * *\end{array}$ & $\begin{array}{l}{[0,25]} \\
0.43 * * *\end{array}$ & $\begin{array}{c}{[0,25]} \\
043 * * *\end{array}$ \\
\hline & {$[0,03]$} & {$[0,03]$} & {$[0,03]$} & {$[0,03]$} & {$[0,03]$} \\
\hline \multirow[t]{2}{*}{ Constante } & $-6,20^{* * *}$ & $-6,08^{* * *}$ & $-6,08^{* * *}$ & $-6,08^{* * *}$ & $-6,08 * * *$ \\
\hline & {$[0,62]$} & {$[0,65]$} & {$[0,65]$} & {$[0,65]$} & {$[0,65]$} \\
\hline Dummies de ano & Sim & Sim & Sim & Sim & $\operatorname{Sim}$ \\
\hline Dummies de UF & Sim & Sim & Sim & Sim & Sim \\
\hline Lambda & $\begin{array}{l}-3,08 \\
{[4,38]}\end{array}$ & $\begin{array}{c}1,76 \\
{[3,09]}\end{array}$ & $\begin{array}{c}0,01 \\
{[1,81]}\end{array}$ & $\begin{array}{l}-27,99 \\
{[57,31]}\end{array}$ & $\begin{array}{c}24,87 \\
{[40,01]}\end{array}$ \\
\hline Observações censuradas & 58.612 & 58.612 & 58.612 & 58.612 & 58.612 \\
\hline Observações não censuradas & 256 & 224 & 224 & 224 & 224 \\
\hline
\end{tabular}

Fonte: elaboração própria

Nota: erro-padrão robusto entre colchetes; ${ }^{* * *}=$ Significante a $1 \% ; * *=$ Significante a $5 \%{ }^{*}=$ Significante a $10 \%$; Lambda se refere ao produto da correlação entre os resíduos do primeiro e do segundo estágio e o desvio-padrão do resíduo do segundo estágio

que a dummy de alinhamento assume, na maioria dos casos, coeficientes estatisticamente nulos. No caso do alinhamento com os partidos da coligação, a dummy de alinhamento assume significância estatística para o prazo de amortização e para o prazo de carência em alguns casos, mas este resultado não é consistente entre as diferentes especificações. $\mathrm{O}$ mesmo vale para prazo de carência no caso do alinhamento com os partidos da coligação e/ou dos ministros.

Além das estimações RDD paramétricas obtidas via pooled OLS, a Tabela 19 apre- 
Tabela 17 - Alinhamento partidário e financiamento do BNDES aos municípios - viés de seleção - alinhamento com partidos da coligação e/ou dos ministros

\begin{tabular}{|c|c|c|c|c|c|}
\hline \multirow[b]{2}{*}{$\begin{array}{l}\text { Coeficiente } \\
{[\text { Erro-padrão] }}\end{array}$} & \multicolumn{2}{|l|}{ Total } & \multicolumn{2}{|c|}{ Reembolsável } & \multirow[b]{2}{*}{$\begin{array}{l}\text { Prazo de } \\
\text { carência }\end{array}$} \\
\hline & $\begin{array}{c}\text { Valor do } \\
\text { financiamento }\end{array}$ & $\begin{array}{c}\text { Valor do } \\
\text { financiamento }\end{array}$ & $\begin{array}{l}\text { Taxa de } \\
\text { juros }\end{array}$ & $\begin{array}{c}\text { Prazo de } \\
\text { amortização }\end{array}$ & \\
\hline \multicolumn{6}{|c|}{ Segundo estágio } \\
\hline Alinhamento & $-0,13$ & $-0,04$ & $-0,11$ & $-3,42$ & 1,67 \\
\hline \multirow{3}{*}{ Fragmentação } & {$[0,46]$} & {$[0,40]$} & {$[0,24]$} & {$[8,00]$} & {$[6,96]$} \\
\hline & $-0,79$ & $-1,18$ & $-0,14$ & 6,64 & $-12,37$ \\
\hline & {$[0,92]$} & {$[0,73]$} & {$[0,43]$} & {$[14,82]$} & {$[12,95]$} \\
\hline \multirow{2}{*}{ DCL/RCL } & $-0,88$ & 0,55 & 0,05 & $-15,45$ & 9,78 \\
\hline & {$[1,35]$} & {$[0,96]$} & {$[0,58]$} & {$[19,17]$} & {$[16,63]$} \\
\hline \multirow[t]{2}{*}{ Pessoal/RCL } & $2,42^{*}$ & 0,90 & 0,56 & 11,88 & $-0,59$ \\
\hline & {$[1,46]$} & {$[1,01]$} & {$[0,59]$} & {$[21,06]$} & {$[18,56]$} \\
\hline \multirow[t]{2}{*}{ Jovens } & 5,83 & $-5,39$ & $-2,29$ & 73,43 & $-119,58$ \\
\hline & {$[12,66]$} & {$[8,93]$} & {$[5,35]$} & {$[179,62]$} & {$[156,20]$} \\
\hline \multirow[t]{2}{*}{ Urbanização } & $-0,77$ & 1,00 & $-0,21$ & $-11,98$ & 12,56 \\
\hline & {$[1,60]$} & {$[1,52]$} & {$[0,92]$} & {$[30,18]$} & {$[26,11]$} \\
\hline \multirow[t]{2}{*}{ População } & $-0,06$ & 1,61 & 0,13 & $-7,58$ & 13,80 \\
\hline & {$[1,56]$} & {$[1,13]$} & {$[0,69]$} & {$[22,46]$} & {$[19,42]$} \\
\hline \multirow[t]{2}{*}{ Constante } & $\begin{array}{l}21,45 \\
{[2473]}\end{array}$ & $\begin{array}{l}-4,65 \\
{[18,44]}\end{array}$ & $\begin{array}{l}2,15 \\
{[1122]}\end{array}$ & $\begin{array}{l}230,25 \\
{[365,38]}\end{array}$ & $\begin{array}{l}-173,56 \\
{[315,63]}\end{array}$ \\
\hline & {$[24,73]$} & {$[18,44]$} & {$[11,22]$} & {$[365,38]$} & {$[315,63]$} \\
\hline \multirow{2}{*}{$\begin{array}{l}\text { Dummies de ano } \\
\text { Dummies de UF }\end{array}$} & Sim & Sim & Sim & Sim & Sim \\
\hline \multirow{2}{*}{\multicolumn{6}{|c|}{ Primeiro estágio }} \\
\hline & & & & & \\
\hline \multirow[t]{2}{*}{ Alinhamento } & $0,12^{* *}$ & $0,15^{* *}$ & $0,15^{* *}$ & $0,15^{* *}$ & $0,15^{* *}$ \\
\hline & {$[0,06]$} & {$[0,06]$} & {$[0,06]$} & {$[0,06]$} & {$[0,06]$} \\
\hline \multirow[t]{2}{*}{ Fragmentação } & $-0,19$ & $-0,24$ & $-0,24$ & $-0,24$ & $-0,24$ \\
\hline & {$[0,20]$} & {$[0,21]$} & {$[0,21]$} & {$[0,21]$} & {$[0,21]$} \\
\hline \multirow[t]{2}{*}{ DCL/RCL } & $0,36^{* * *}$ & $0,34^{* * *}$ & $0,34^{* * *}$ & $0,34^{* * *}$ & $0,34^{* * *}$ \\
\hline & {$[0,11]$} & {$[0,11]$} & {$[0,11]$} & {$[0,11]$} & {$[0,11]$} \\
\hline \multirow[t]{2}{*}{ Pessoal/RCL } & 0,01 & 0,01 & 0,01 & 0,01 & 0,01 \\
\hline & {$[0,38]$} & {$[0,41]$} & {$[0,41]$} & {$[0,41]$} & {$[0,41]$} \\
\hline \multirow[t]{2}{*}{ Jovens } & $-3,59 * * *$ & $-3,46^{* * *}$ & $-3,46^{* * *}$ & $-3,46^{* * *}$ & $-3,46^{* * *}$ \\
\hline & {$[1,12]$} & {$[1,17]$} & {$[1,17]$} & {$[1,17]$} & {$[1,17]$} \\
\hline Urbanização & $\begin{array}{l}0,35 \\
0,33]\end{array}$ & $\begin{array}{l}0,50^{* *} \\
{[0,57]}\end{array}$ & $\begin{array}{l}0,50^{* *} \\
{[025]}\end{array}$ & $0,50^{* *}$ & $\begin{array}{l}0,50^{* *} \\
0251\end{array}$ \\
\hline \multirow[t]{2}{*}{ População } & $\begin{array}{c}{[0,23]} \\
0,45^{* * *}\end{array}$ & $\begin{array}{c}{[0,25]} \\
0,44^{* * *}\end{array}$ & $\begin{array}{c}{[0,25]} \\
0,44^{* * *}\end{array}$ & $\begin{array}{c}{[0,25]} \\
0,44^{* * *}\end{array}$ & $\begin{array}{c}{[0,25]} \\
0,44^{* * *}\end{array}$ \\
\hline & {$[0,03]$} & {$[0,03]$} & {$[0,03]$} & {$[0,03]$} & {$[0,03]$} \\
\hline \multirow[t]{2}{*}{ Constante } & $-6,30 * * *$ & $-6,20 * * *$ & $-6,20 * * *$ & $-6,20 * * *$ & $-6,20 * * *$ \\
\hline & {$[0,63]$} & {$[0,65]$} & {$[0,65]$} & {$[0,65]$} & {$[0,65]$} \\
\hline \multirow{2}{*}{$\begin{array}{l}\text { Dummies de ano } \\
\text { Dummies de UF }\end{array}$} & Sim & Sim & Sim & Sim & Sim \\
\hline & Sim & Sim & Sim & Sim & Sim \\
\hline Lambda & $\begin{array}{l}-2,71 \\
{[3,95]}\end{array}$ & $\begin{array}{c}1,16 \\
{[2,98]}\end{array}$ & $\begin{array}{c}0,01 \\
{[1,81]}\end{array}$ & $\begin{array}{l}-32,57 \\
{[58,95]}\end{array}$ & $\begin{array}{c}31,22 \\
{[50,90]}\end{array}$ \\
\hline Observações censuradas & 58.612 & 58.612 & 58.612 & 58.612 & 58.612 \\
\hline Observações não censuradas & 256 & 224 & 224 & 224 & 224 \\
\hline
\end{tabular}

Fonte: elaboração própria

Nota: erro-padrão robusto entre colchetes; ${ }^{* * *}=$ Significante a $1 \% ;{ }^{* *}=$ Significante a $5 \%{ }^{*}=$ Significante a $10 \%$; Lambda se refere ao produto da correlação entre os resíduos do primeiro e do segundo estágio e o desvio-padrão do resíduo do segundo estágio

senta os resultados obtidos por meio da abordagem RDD não-paramétrica. Conforme pode ser observado, qualquer que seja a medida de alinhamento com o governo federal, os resultados continuam indicando efeito estatisticamente nulo do alinhamento sobre o valor do financiamento ou sobre as condições de devolução ${ }^{49}$. Estes resultados são corroborados pelas Figuras 4, 5, 6, 7 e 8, que ilustram o comportamento de funções não-paramétricas

49 Embora uma das estimativas associadas ao prazo de amortização seja estatisticamente significante, as demais não são. 
de ajuste polinomial local separadamente para municípios alinhados e não alinhados com o governo federal ${ }^{50}$.

\subsubsection{Sobre a validade dos resultados obtidos via RDD}

Conforme Imbens e Lemieux (2008) e Klaauw (2008), os resultados obtidos via método RDD são válidos, entre outros, caso as variáveis de controle não exibam descontinuidade em torno do threshold de interesse (no caso aqui investigado, em torno da margem de vitória igual a zero). Conforme pode ser visto na Tabela B.1 e nas Figuras B.1, B.2, B.3, B.4, B.5 e B.6 do Apêndice B desta tese, algumas delas, em especial, o índice de fragmentação de votos, apresenta a referida característica, o que pode invalidar os resultados anteriormente apresentados. Assim, optou-se por realizar um exercício adicional em que as variáveis dependentes foram inicialmente regredidas em função das próprias variáveis de controle e, posteriormente, submetidas a novos testes não-paramétricos de descontinuidade. Os resultados desse exercício adicional são apresentados na Tabela B.2 do Apêndice $\mathrm{B}$, e sugerem que o efeito do alinhamento sobre todas as variáveis dependentes continua sendo nulo, qualquer que seja a medida de alinhamento e qualquer que seja o método de definição da banda empregado ${ }^{51}$.

O método RDD também pressupõe que não há manipulação da variável que define as unidades tratadas e não tratadas. No estudo aqui realizado, isto equivale a pressupor que não há manipulação da margem de vitória, que define os candidatos eleitos das localidades alinhadas e não alinhadas com o governo federal. Esta parece ser uma hipótese bastante plausível para o problema aqui investigado dado que o processo eleitoral brasileiro permite baixa possibilidade de manipulação dos resultados ${ }^{52}$. Assim, segundo McCrary (2008), esperar-se-ia que distribuição da proporção de votos fosse suave, ou seja, sem apresentar nenhum tipo de descontinuidade.

No caso das eleições municipais brasileiras, a definição do candidato eleito depende do tamanho do eleitorado de cada município dado que em municípios com mais de 200 mil eleitores ocorre segundo turno caso o candidato mais bem votado no primeiro turno não obtenha maioria absoluta dos votos. Nos municípios com menos de 200 mil eleitores, por sua vez, nos quais há somente um turno, vence o candidato que obtiver maioria simples dos votos. Assim, para testar a possibilidade de que a distribuição de votos é suave, realizouse o teste de continuidade da densidade da distribuição de votos considerando apenas aqueles municípios sujeitos a segundo turno ou em que houve somente dois candidatos dado que, nesses casos, o candidato vitorioso obteve maioria absoluta (mais de 50\%) dos votos e há, portanto, um threshold bem definido ${ }^{53}$. Em particular, para esse teste, foram considerados os resultados das eleições municipais de 2000, 2004 e 2008, que definiram os prefeitos eleitos presentes na amostra aqui explorada.

50 Essas funções também foram obtidas via polinômios locais de primeira ordem via kernel do tipo Triangular.

51 Note que uma das estimativas para o prazo de amortização continua sendo estatisticamente significante, mas este resultado não é reforçado pelas demais cinco.

52 Essa hipótese também é compartilhada por Fujiwara (2015) e Arvate, Barbosa e Fuzitani (2016), por exemplo.

53 Note que o mesmo não pode ser dito para os municípios com menos de 200 mil eleitores com mais de dois candidatos. 
A Figura B.7, apresentada no Apêndice B desta tese, apresenta o histograma e a densidade da distribuição da proporção de votos recebida pelo candidato a prefeito eleito e pelo segundo colocado, normalizados em torno threshold igual a zero ${ }^{54,55}$. Os resultados obtidos permitem constatar a ausência de descontinuidade ao redor da margem de vitória igual a zero, garantindo assim maior confiabilidade aos resultados apresentados para o caso dos municípios ${ }^{56}$.

54 Isto é, a proporção de votos recebida por cada um dos dois candidatos descontada de 50\%. Assim, supondo que um candidato tenha sido eleito com $51 \%$ dos votos e o segundo colocado (derrotado) tenha recebido $49 \%$ dos votos, as margens normalizadas passam a ser positiva e igual a $1 \%$ para o candidato eleito e negativa e igual a $-1 \%$ para o candidato derrotado.

55 Obtida de forma não-paramétrica via kernel de Epanechnikov.

56 Note que a Figura B.7 é bastante semelhante à Figura 4 de McCrary (2008), o que fortalece o resultado de densidade contínua. 


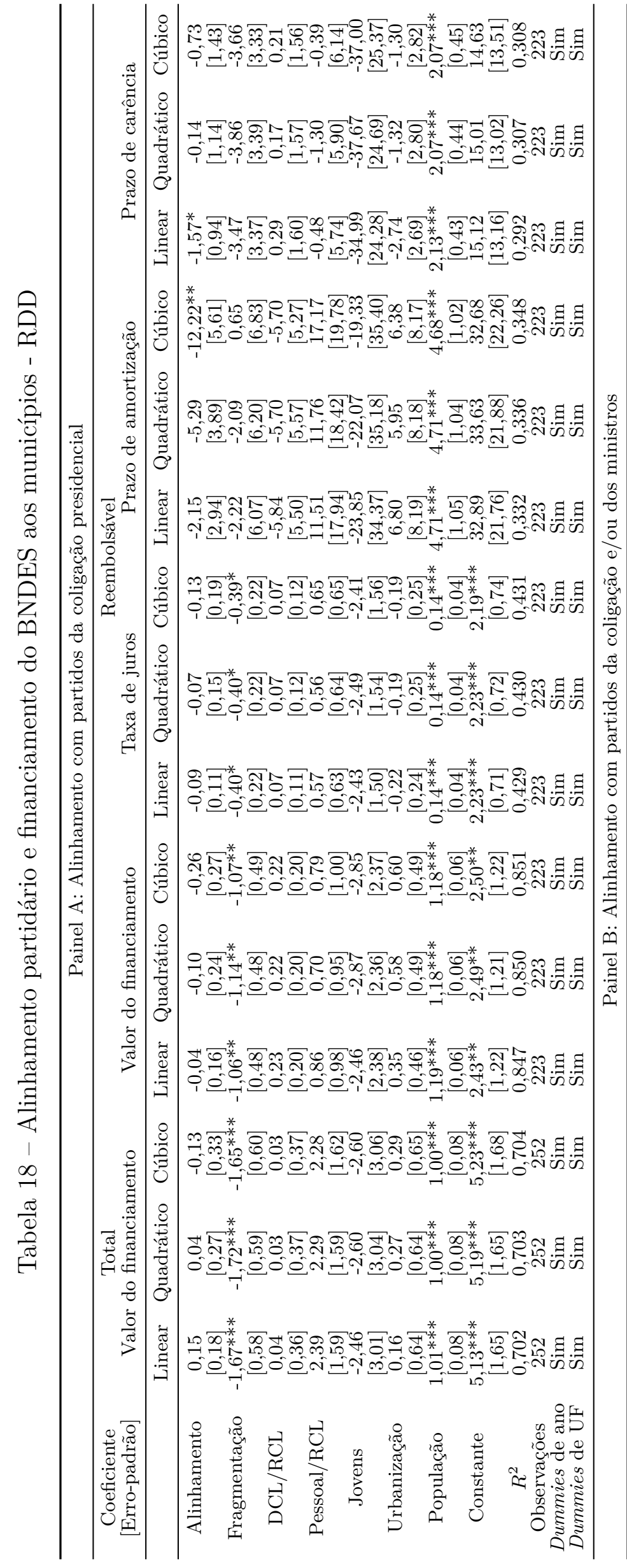

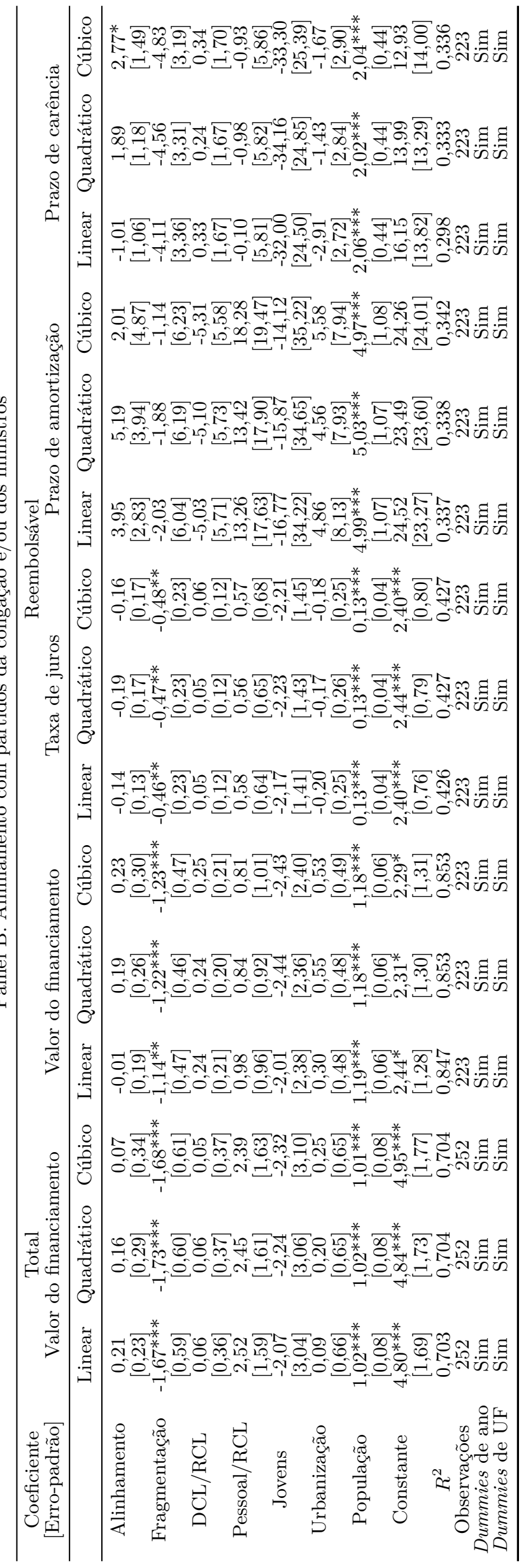

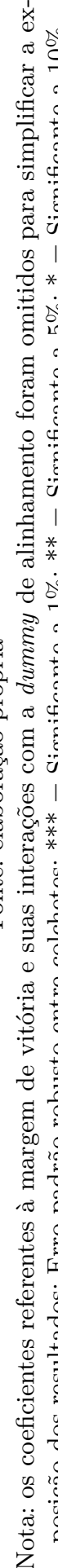


Tabela 19 - Testes não paramétricos de descontinuidade - municípios

\begin{tabular}{|c|c|c|c|c|c|}
\hline & Total & \multicolumn{4}{|c|}{ Reembolsável } \\
\hline & $\begin{array}{c}\text { Valor do } \\
\text { financiamento }\end{array}$ & $\begin{array}{c}\text { Valor do } \\
\text { financiamento }\end{array}$ & $\begin{array}{c}\text { Taxa de } \\
\text { juros }\end{array}$ & $\begin{array}{c}\text { Prazo de } \\
\text { amortização }\end{array}$ & $\begin{array}{c}\text { Prazo de } \\
\text { carência }\end{array}$ \\
\hline \multicolumn{6}{|c|}{$\mathrm{CCT}$} \\
\hline $\begin{array}{c}\text { Diferença alinhado x não alinhado } \\
\text { Erro-padrão } \\
\text { Observações }\end{array}$ & $\begin{array}{c}0,22 \\
{[0,81]} \\
171\end{array}$ & $\begin{array}{c}0,34 \\
{[0,89]} \\
159\end{array}$ & $\begin{array}{c}0,06 \\
{[0,23]} \\
131\end{array}$ & $\begin{array}{c}-11,44 \\
{[7,48]} \\
129\end{array}$ & $\begin{array}{c}0,79 \\
{[2,49]} \\
120\end{array}$ \\
\hline \multicolumn{6}{|c|}{ IK } \\
\hline $\begin{array}{c}\text { Diferença alinhado x não alinhado } \\
\text { Erro-padrão } \\
\text { Observações }\end{array}$ & $\begin{array}{c}-0,07 \\
{[0,92]} \\
123\end{array}$ & $\begin{array}{c}-0,25 \\
{[1,08]} \\
114\end{array}$ & $\begin{array}{c}0,31 \\
{[0,44]} \\
158\end{array}$ & $\begin{array}{c}-11,58 \\
{[7,71]} \\
139\end{array}$ & $\begin{array}{c}0,83 \\
{[2,90]} \\
109\end{array}$ \\
\hline \multicolumn{6}{|c|}{$\mathrm{CV}$} \\
\hline $\begin{array}{c}\text { Diferença alinhado x não alinhado } \\
\text { Erro-padrão } \\
\text { Observações }\end{array}$ & $\begin{array}{c}0,23 \\
{[0,63]} \\
250\end{array}$ & $\begin{array}{c}0,25 \\
{[0,70]} \\
223\end{array}$ & $\begin{array}{c}0,04 \\
{[0,16]} \\
223\end{array}$ & $\begin{array}{c}-12,07^{* *} \\
{[5,52]} \\
202\end{array}$ & $\begin{array}{c}-0,96 \\
{[1,76]} \\
216\end{array}$ \\
\hline \multicolumn{6}{|c|}{ Painel B: Alinhamento com partidos da coligação e/ou dos ministros } \\
\hline & $\begin{array}{c}\text { Valor do } \\
\text { financiamento }\end{array}$ & $\begin{array}{c}\text { Valor do } \\
\text { financiamento }\end{array}$ & $\begin{array}{c}\text { Taxa de } \\
\text { juros }\end{array}$ & $\begin{array}{c}\text { Prazo de } \\
\text { amortização }\end{array}$ & $\begin{array}{l}\text { Prazo de } \\
\text { carência }\end{array}$ \\
\hline \multicolumn{6}{|c|}{$\mathrm{CCT}$} \\
\hline $\begin{array}{c}\text { Diferença alinhado x não alinhado } \\
\text { Erro-padrão } \\
\text { Observações }\end{array}$ & $\begin{array}{c}0,08 \\
{[0,60]} \\
176\end{array}$ & $\begin{array}{c}0,10 \\
{[0,70]} \\
158\end{array}$ & $\begin{array}{c}0,03 \\
{[0,19]} \\
157\end{array}$ & $\begin{array}{c}-3,99 \\
{[8,10]} \\
136\end{array}$ & $\begin{array}{c}2,01 \\
{[2,15]} \\
141\end{array}$ \\
\hline \multicolumn{6}{|c|}{ IK } \\
\hline $\begin{array}{c}\text { Diferença alinhado x não alinhado } \\
\text { Erro-padrão } \\
\text { Observações }\end{array}$ & $\begin{array}{c}-0,62 \\
{[0,77]} \\
124\end{array}$ & $\begin{array}{c}-0,69 \\
{[1,01]} \\
112\end{array}$ & $\begin{array}{c}-0,21 \\
{[0,35]} \\
121\end{array}$ & $\begin{array}{c}-4,16 \\
{[9,38]} \\
113\end{array}$ & $\begin{array}{c}0,65 \\
{[2,97]} \\
138\end{array}$ \\
\hline \multicolumn{6}{|c|}{$\mathrm{CV}$} \\
\hline $\begin{array}{c}\text { Diferença alinhado x não alinhado } \\
\text { Erro-padrão } \\
\text { Observações }\end{array}$ & $\begin{array}{c}-0,11 \\
{[0,50]} \\
250\end{array}$ & $\begin{array}{c}-0,01 \\
{[0,56]} \\
223\end{array}$ & $\begin{array}{c}-0,08 \\
{[0,16]} \\
223\end{array}$ & $\begin{array}{c}1,00 \\
{[5,97]} \\
223\end{array}$ & $\begin{array}{c}1,58 \\
{[1,86]} \\
209\end{array}$ \\
\hline
\end{tabular}

Fonte: elaboração própria

Nota: diferença se refere ao valor da diferença da variável entre unidades alinhadas e não alinhadas em torno da margem de vitória igual a zero; CCT, IK e CV se referem aos métodos de definição da banda (bandwidth) propostos por Calonico, Cattaneo e Titiunik (2014), Imbens e Kalyanaraman (2012) e Ludwig e Miller (2007), respectivamente; $* * *=$ Significante a $1 \% ; * *=$ Significante a $5 \%$; ${ }^{*}=$ Significante a $10 \%$.

\subsubsection{Análise dos estados}

\subsubsection{Método de viés de seleção}

Analisando-se o caso dos estados, as Tabelas 20 e 21 apresentam os resultados obtidos a partir das estimações do tipo pooled Heckman para controle do viés de seleção amostral. A primeira dessas duas tabelas apresenta os resultados para o alinhamento com partidos da coligação, ao passo que a segunda apresenta os resultados para o alinhamento com partidos da coligação e/ou dos ministros.

Os resultados indicam que o alinhamento exerce efeito positivo sobre o valor do financiamento, seja ele total ou do tipo reembolsável, para ambas as medidas de alinhamento. Note que os coeficientes referentes à dummy de alinhamento são positivos e 


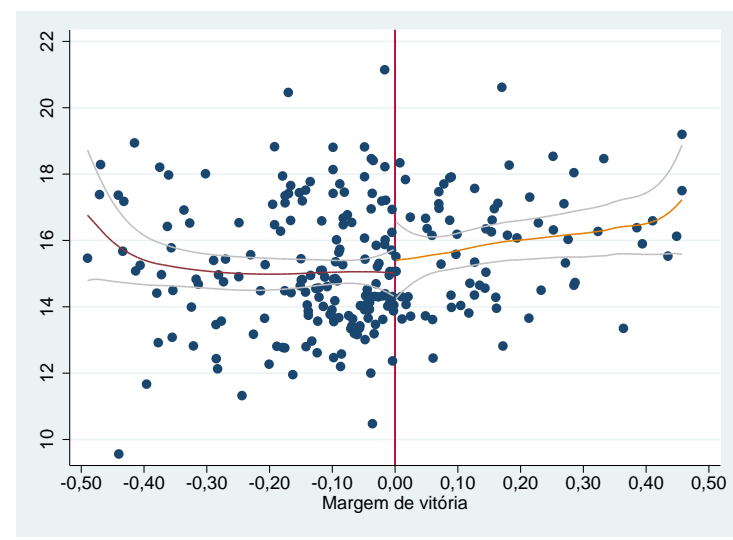

(a) Alinhamento com coligação

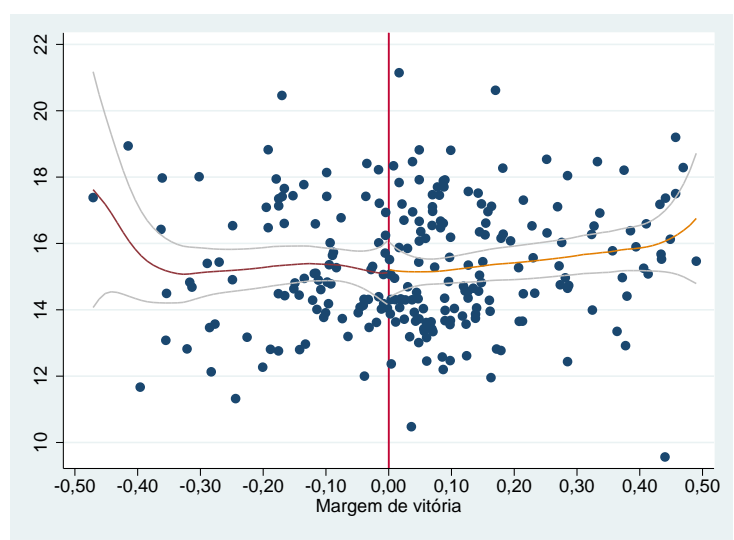

(b) Alinhamento com ministérios

Figura 4 - Valor do financiamento (total) - municípios

Fonte: elaboração própria

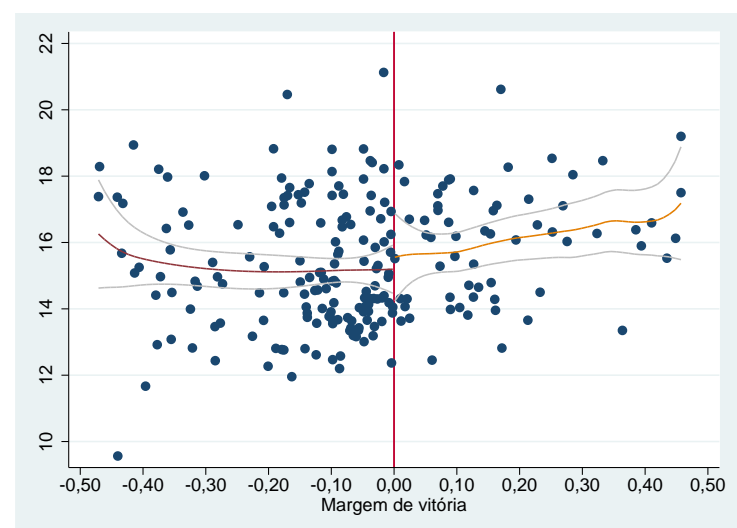

(a) Alinhamento com coligação

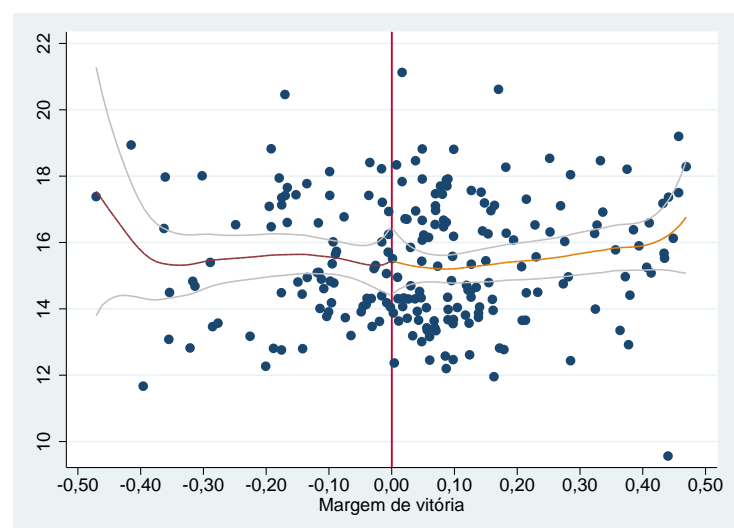

(b) Alinhamento com ministérios

Figura 5 - Valor do financiamento (reembolsável) - municípios

Fonte: elaboração própria

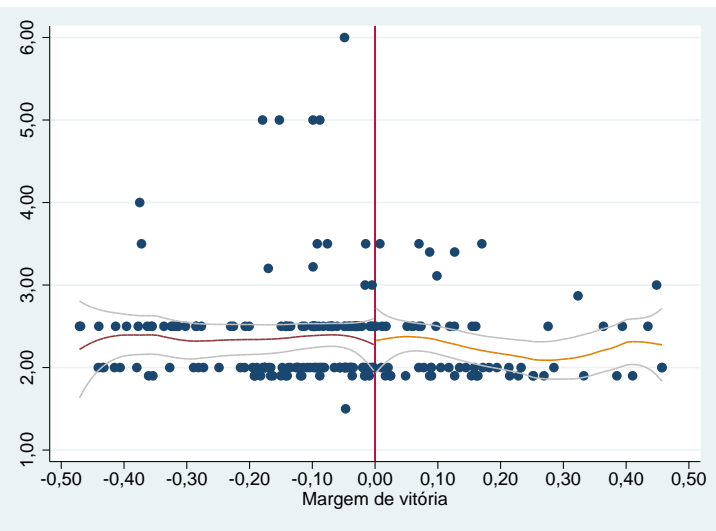

(a) Alinhamento com coligação

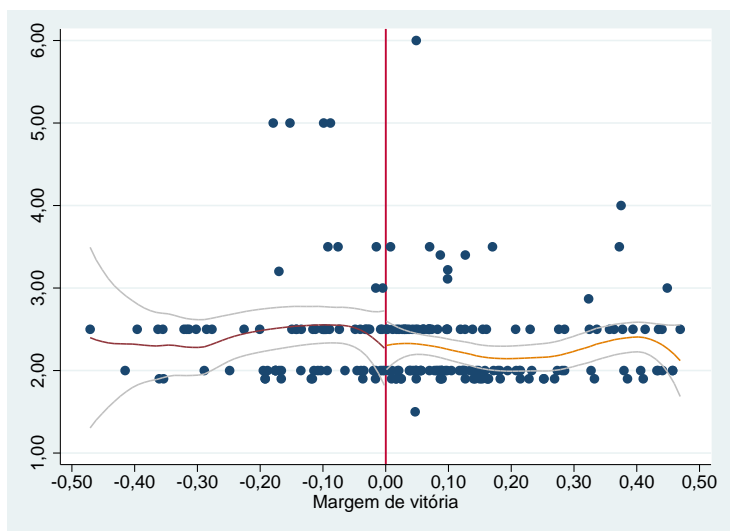

(b) Alinhamento com ministérios

Figura 6 - Taxa de juros - municípios

Fonte: elaboração própria 


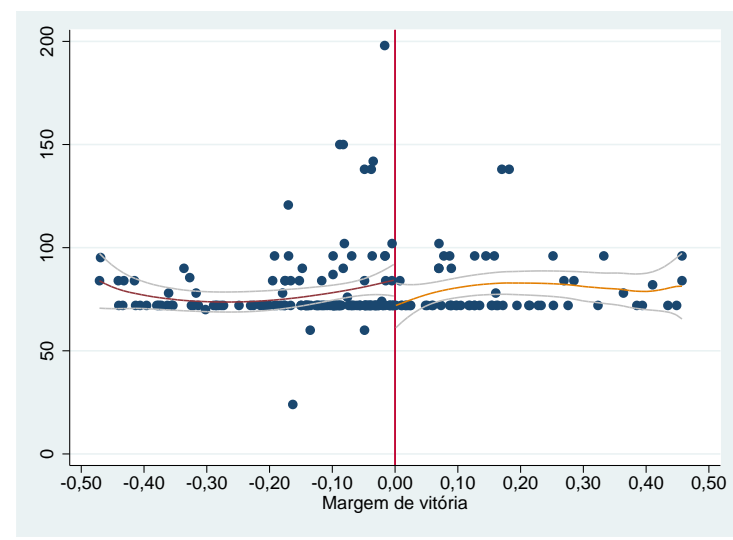

(a) Alinhamento com coligação

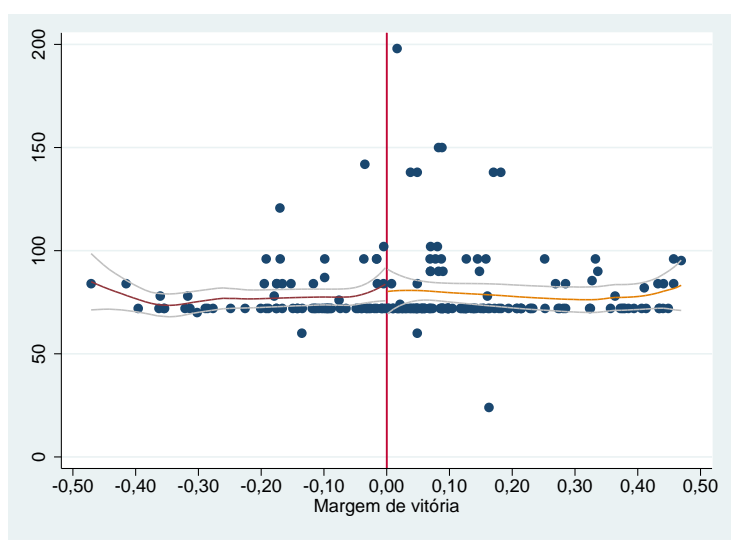

(b) Alinhamento com ministérios

Figura 7 - Prazo de amortização - municípios

Fonte: elaboração própria

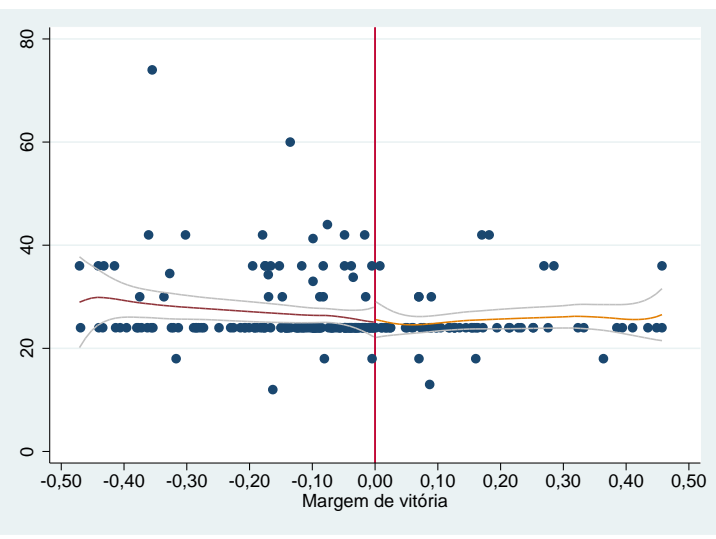

(a) Alinhamento com coligação

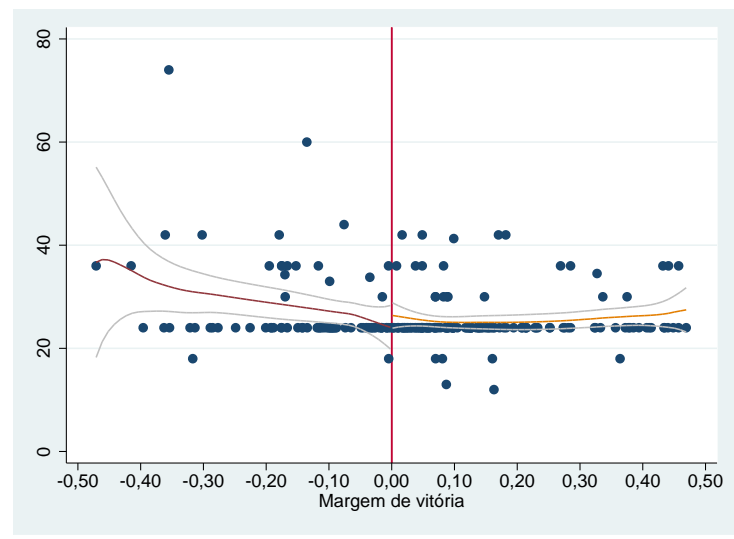

(b) Alinhamento com ministérios

Figura 8 - Prazo de carência - municípios

Fonte: elaboração própria

estatisticamente significantes ao nível máximo de $5 \%$ nos quatro casos. Já os efeitos do alinhamento sobre a taxa de juros, prazo de amortização e prazo de carência são estatisticamente nulos. Ademais, de modo semelhante ao caso dos municípios, os resultados do primeiro estágio sugerem que estados cuja razão DCL/RCL está mais distante do limite estabelecido pela LRF apresentam maior probabilidade de solicitação de recursos junto ao BNDES, em particular, do tipo reembolsável. Para os estados, contudo, o efeito do alinhamento sobre a probabilidade de solicitação é estatisticamente nulo, diferentemente do observado no caso dos municípios.

Em relação às variáveis de controle, nota-se que quanto maior a distância da razão DCL/RCL em relação ao limite estabelecido pela LRF, maior parece ser o prazo de carência dos financiamentos. Contudo, o efeito deste regressor é nulo sobre as demais variáveis dependentes. Por sua vez, quanto maior a distância da razão Pessoal/RCL em relação ao limite estabelecido pela LRF, menor tende a ser o montante do financiamento tomado seja ele total ou especificamente do tipo reembolsável, qualquer que seja a medida de alinhamento considerada. Uma possível interpretação para este resultado pode residir 
no fato de que estados com orçamentos menos comprometidos com gastos com pessoal exibem mais "folga" fiscal, diminuindo o montante necessário de recursos junto ao BNDES para a realização de investimentos públicos. De fato, conforme mencionado anteriormente, boa parte dos financiamentos tomados pelos estados junto ao BNDES está associada a projetos de infra-estrutura.

Tabela 20 - Alinhamento partidário e financiamento do BNDES aos estados - viés de seleção - alinhamento com partidos da coligação presidencial

\begin{tabular}{|c|c|c|c|c|c|}
\hline \multirow[b]{2}{*}{$\begin{array}{c}\text { Coeficiente } \\
\text { [Erro-padrão] }\end{array}$} & \multicolumn{2}{|l|}{ Total } & \multicolumn{2}{|c|}{ Reembolsável } & \multirow[b]{2}{*}{$\begin{array}{l}\text { Prazo de } \\
\text { carência }\end{array}$} \\
\hline & $\begin{array}{c}\text { Valor do } \\
\text { financiamento }\end{array}$ & $\begin{array}{c}\text { Valor do } \\
\text { financiamento }\end{array}$ & $\begin{array}{c}\text { Taxa de } \\
\text { juros }\end{array}$ & $\begin{array}{c}\text { Prazo de } \\
\text { amortização }\end{array}$ & \\
\hline \multicolumn{6}{|c|}{ Segundo estágio } \\
\hline Alinhamento & $\begin{array}{c}1,08^{* *} \\
{[0,52]}\end{array}$ & $\begin{array}{c}0,75^{* *} \\
{[0,31]}\end{array}$ & $\begin{array}{l}-0,10 \\
{[0,16]}\end{array}$ & $\begin{array}{c}-9,85 \\
{[12,13]}\end{array}$ & $\begin{array}{l}-0,60 \\
{[3,30]}\end{array}$ \\
\hline \multirow[t]{2}{*}{ Fragmentação } & $5,06^{*}$ & $\begin{array}{l}{[0,01]} \\
1,08\end{array}$ & {$[0,10]$} & $111,89^{*}$ & $-1,26$ \\
\hline & {$[2,60]$} & {$[1,63]$} & {$[0,83]$} & {$[65,04]$} & {$[17,44]$} \\
\hline \multirow{2}{*}{ DCL/RCL } & $-0,27$ & 0,48 & 0,43 & $-37,76$ & $25,28^{*}$ \\
\hline & $\begin{array}{c}{[1,66]} \\
-6,31^{* *}\end{array}$ & $\begin{array}{c}{[1,22]} \\
-3,64^{* *}\end{array}$ & $\begin{array}{c}{[0,63]} \\
0,30\end{array}$ & $\begin{array}{l}{[47,13]} \\
-61,80\end{array}$ & $\begin{array}{c}{[13,17]} \\
12,88\end{array}$ \\
\hline Pessoal/RCL & {$[2,68]$} & {$[1,49]$} & {$[0,76]$} & {$[58,92]$} & {$[16,03]$} \\
\hline \multirow[t]{2}{*}{ Jovens } & $-24,42$ & $-8,89$ & $-3,62$ & 800,87 & 421,24 \\
\hline & {$[48,31]$} & {$[27,68]$} & {$[14,15]$} & {$[1.094,47]$} & {$[297,48]$} \\
\hline \multirow[t]{2}{*}{ Urbanização } & $-5,10$ & 8,77 & 9,55 & $-313,61$ & $-30,00$ \\
\hline & {$[21,63]$} & {$[11,55]$} & {$[5,90]$} & {$[457,31]$} & {$[124,07]$} \\
\hline \multirow[t]{2}{*}{ População } & $-20,70^{* *}$ & $-3,98$ & 3,37 & $-145,64$ & 81,26 \\
\hline & {$[9,91]$} & {$[6,15]$} & {$[3,20]$} & {$[238,57]$} & {$[66,65]$} \\
\hline \multirow[t]{2}{*}{ Constante } & $306,43^{* *}$ & 68,48 & $-46,13$ & $1.982,90$ & $-1.216,39$ \\
\hline & {$[140,70]$} & {$[86,86]$} & {$[45,23]$} & {$[3365,69]$} & {$[941,31]$} \\
\hline \multirow[t]{2}{*}{ Dummies de ano } & Sim & Sim & Sim & Sim & Sim \\
\hline & \multicolumn{2}{|c|}{ Primeiro estágio } & & & \\
\hline \multirow[t]{2}{*}{ Alinhamento } & 0,22 & 0,38 & 0,38 & 0,38 & 0,38 \\
\hline & {$[0,32]$} & {$[0,34]$} & {$[0,34]$} & {$[0,34]$} & {$[0,34]$} \\
\hline \multirow[t]{2}{*}{ Fragmentação } & $-2,58 * *$ & $-0,32$ & $-0,32$ & $-0,32$ & $-0,32$ \\
\hline & {$[1,28]$} & {$[1,77]$} & {$[1,77]$} & {$[1,77]$} & {$[1,77]$} \\
\hline \multirow[t]{2}{*}{ DCL/RCL } & 0,80 & $2,21^{* *}$ & $2,21^{* *}$ & $2,21 * *$ & $2,21 * *$ \\
\hline & {$[0,68]$} & {$[0,92]$} & {$[0,92]$} & {$[0,92]$} & {$[0,92]$} \\
\hline \multirow[t]{2}{*}{ Pessoal/RCL } & 2,36 & 0,99 & 0,99 & 0,99 & 0,99 \\
\hline & {$[1,63]$} & {$[1,71]$} & {$[1,71]$} & {$[1,71]$} & {$[1,71]$} \\
\hline \multirow[t]{2}{*}{ Jovens } & 18,85 & 10,36 & 10,36 & 10,36 & 10,36 \\
\hline & {$[30,00]$} & {$[32,01]$} & {$[32,01]$} & {$[32,01]$} & {$[32,01]$} \\
\hline \multirow[t]{2}{*}{ Urbanização } & 15,55 & 3,38 & 3,38 & 3,38 & 3,38 \\
\hline & {$[14,23]$} & {$[13,89]$} & {$[13,89]$} & {$[13,89]$} & {$[13,89]$} \\
\hline \multirow[t]{2}{*}{ População } & 6,71 & $-2,11$ & $-2,11$ & $-2,11$ & $-2,11$ \\
\hline & {$[5,43]$} & {$[5,32]$} & {$[5,32]$} & {$[5,32]$} & {$[5,32]$} \\
\hline \multirow[t]{2}{*}{ Constante } & $-107,00$ & 18,99 & 18,99 & 18,99 & 18,99 \\
\hline & {$[78,13]$} & {$[74,93]$} & {$[74,93]$} & {$[74,93]$} & {$[74,93]$} \\
\hline Dummies de ano & Sim & Sim & Sim & Sim & Sim \\
\hline Lambda & $\begin{array}{c}-1,95^{* *} \\
{[0,91]}\end{array}$ & $\begin{array}{l}-0,61 \\
{[0,56]}\end{array}$ & $\begin{array}{l}-0,05 \\
{[0,29]}\end{array}$ & $\begin{array}{l}-34,25 \\
{[21,87]}\end{array}$ & $\begin{array}{l}-4,96 \\
{[6,00]}\end{array}$ \\
\hline Observações censuradas & 215 & 237 & 237 & 237 & 237 \\
\hline Observações não censuradas & 136 & 114 & 114 & 114 & 114 \\
\hline
\end{tabular}

Fonte: elaboração própria

Nota: erro-padrão robusto entre colchetes; ${ }^{* * *}=$ Significante a $1 \% ;{ }^{* *}=$ Significante a $5 \% ;^{*}=$ Significante a $10 \%$; Lambda se refere ao produto da correlação entre os resíduos do primeiro e do segundo estágio e o desvio-padrão do resíduo do segundo estágio 
Tabela 21 - Alinhamento partidário e financiamento do BNDES aos estados - viés de seleção - alinhamento com partidos da coligação e/ou dos ministros

\begin{tabular}{|c|c|c|c|c|c|}
\hline \multirow[b]{2}{*}{$\begin{array}{c}\text { Coeficiente } \\
\text { [Erro-padrão] }\end{array}$} & \multicolumn{2}{|l|}{ Total } & \multicolumn{2}{|c|}{ Reembolsável } & \multirow[b]{2}{*}{$\begin{array}{l}\text { Prazo de } \\
\text { carência }\end{array}$} \\
\hline & $\begin{array}{c}\text { Valor do } \\
\text { financiamento }\end{array}$ & $\begin{array}{l}\text { Valor do } \\
\text { financiamento }\end{array}$ & $\begin{array}{l}\text { Taxa de } \\
\text { juros }\end{array}$ & $\begin{array}{c}\text { Prazo de } \\
\text { amortização }\end{array}$ & \\
\hline \multicolumn{6}{|c|}{ Segundo estágio } \\
\hline Alinhamento & $\begin{array}{l}1,21 * * \\
{[0,49]}\end{array}$ & $\begin{array}{c}0,65^{* *} \\
{[0,28]}\end{array}$ & $\begin{array}{l}-0,06 \\
{[0,14]}\end{array}$ & $\begin{array}{c}-3,57 \\
{[10,66]}\end{array}$ & $\begin{array}{l}-1,61 \\
{[2,91]}\end{array}$ \\
\hline \multirow[t]{2}{*}{ Fragmentação } & 3,78 & 0,07 & $\begin{array}{l}-1,12 \\
-0,821\end{array}$ & $116,63^{*}$ & $-1,14$ \\
\hline & $\begin{array}{l}{[2,71]} \\
-0.39\end{array}$ & $\begin{array}{c}{[1,67]} \\
0.38\end{array}$ & {$[0,83]$} & $\begin{array}{l}{[64,23]} \\
-3447\end{array}$ & {$[17,27]$} \\
\hline DCL/RCL & {$[1,74]$} & $\begin{array}{c}0,00 \\
{[1,23]}\end{array}$ & {$[0,63]$} & {$[47,04]$} & {$[13,11]$} \\
\hline \multirow[t]{2}{*}{ Pessoal/RCL } & $-6,75^{* *}$ & $-4,10^{* * *}$ & 0,31 & $-65,57$ & 14,01 \\
\hline & {$[2,87]$} & {$[1,54]$} & {$[0,78]$} & {$[59,16]$} & {$[16,16]$} \\
\hline \multirow[t]{2}{*}{ Jovens } & $-18,57$ & $-3,51$ & $-4,36$ & 778,69 & 420,22 \\
\hline & {$[50,69]$} & {$[28,24]$} & {$[14,16]$} & {$[1.082,50]$} & {$[295,35]$} \\
\hline \multirow[t]{2}{*}{ Urbanização } & $-6,35$ & 10,21 & 9,46 & $-287,38$ & $-26,07$ \\
\hline & {$[22,74]$} & {$[11,76]$} & {$[5,89]$} & {$[450,86]$} & {$[122,85]$} \\
\hline \multirow[t]{2}{*}{ População } & $-17,69^{*}$ & $-2,22$ & 3,26 & $-148,38$ & 80,74 \\
\hline & {$[10,24]$} & {$[6,21]$} & {$[3,20]$} & {$[237,16]$} & {$[66,40]$} \\
\hline \multirow{2}{*}{ Constante } & $265,76^{*}$ & 42,88 & $-44,45$ & $1.995,15$ & $-1.212,29$ \\
\hline & {$[145,10]$} & {$[87,68]$} & {$[45,28]$} & {$[3.345,66]$} & {$[937,87]$} \\
\hline \multirow[t]{2}{*}{ Dummies de ano } & Sim & Sim & $\operatorname{Sim}$ & Sim & Sim \\
\hline & \multicolumn{2}{|c|}{ Primeiro estágio } & & & \\
\hline \multirow[t]{2}{*}{ Alinhamento } & $-0,07$ & 0,35 & 0,35 & 0,35 & 0,35 \\
\hline & {$[0,25]$} & {$[0,29]$} & {$[0,29]$} & {$[0,29]$} & {$[0,29]$} \\
\hline \multirow[t]{2}{*}{ Fragmentação } & $-2,63^{* *}$ & $-0,58$ & $-0,58$ & $-0,58$ & $-0,58$ \\
\hline & {$[1,27]$} & {$[1,76]$} & {$[1,76]$} & {$[1,76]$} & {$[1,76]$} \\
\hline \multirow[t]{2}{*}{ DCL/RCL } & 0,81 & $2,30 * *$ & $2,30 * *$ & $2,30 * *$ & $2,30 * *$ \\
\hline & {$[0,68]$} & {$[0,96]$} & {$[0,96]$} & {$[0,96]$} & {$[0,96]$} \\
\hline \multirow[t]{2}{*}{ Pessoal/RCL } & 2,38 & 0,91 & 0,91 & 0,91 & 0,91 \\
\hline & {$[1,63]$} & {$[1,69]$} & {$[1,69]$} & {$[1,69]$} & {$[1,69]$} \\
\hline \multirow[t]{2}{*}{ Jovens } & 17,73 & 8,03 & 8,03 & 8,03 & 8,03 \\
\hline & {$[29,58]$} & {$[31,58]$} & {$[31,58]$} & {$[31,58]$} & {$[31,58]$} \\
\hline \multirow[t]{2}{*}{ Urbanização } & 14,98 & 2,57 & 2,57 & 2,57 & 2,57 \\
\hline & {$[14,12]$} & {$[13,82]$} & {$[13,82]$} & {$[13,82]$} & {$[13,82]$} \\
\hline \multirow[t]{2}{*}{ População } & 6,45 & $-1,90$ & $-1,90$ & $-1,90$ & $-1,90$ \\
\hline & $\begin{array}{c}{[5,35]} \\
-102,40\end{array}$ & $\begin{array}{l}{[5,34]} \\
17,74\end{array}$ & $\begin{array}{l}{[5,34]} \\
17,74\end{array}$ & {$[5,34]$} & $\begin{array}{l}{[5,34]} \\
17,74\end{array}$ \\
\hline Constante & $\begin{array}{l}-102,40 \\
{[76,91]}\end{array}$ & {$[75,18]$} & {$[75,18]$} & {$[75,18]$} & {$[75,18]$} \\
\hline Dummies de ano & Sim & Sim & Sim & Sim & Sim \\
\hline Lambda & $\begin{array}{c}-2,06^{* *} \\
{[0,98]}\end{array}$ & $\begin{array}{l}-0,77 \\
{[0,56]}\end{array}$ & $\begin{array}{l}-0,07 \\
{[0,28]}\end{array}$ & $\begin{array}{l}-31,47 \\
{[21,27]}\end{array}$ & $\begin{array}{l}-4,10 \\
{[5,85]}\end{array}$ \\
\hline Observações censuradas & 215 & 237 & 237 & 237 & 237 \\
\hline Observações não censuradas & 136 & 114 & 114 & 114 & 114 \\
\hline
\end{tabular}

Fonte: elaboração própria

Nota: erro-padrão robusto entre colchetes; ${ }^{* * *}=$ Significante a $1 \% ;{ }^{* *}=$ Significante a $5 \% ;{ }^{*}=$ Significante a $10 \%$; Lambda se refere ao produto da correlação entre os resíduos do primeiro e do segundo estágio e o desvio-padrão do resíduo do segundo estágio

\subsubsection{Método RDD}

A Tabela 22 apresenta, por sua vez, os resultados referentes à abordagem paramétrica do método RDD. De modo análogo ao apresentado na Tabela 18, para cada variável dependente e para cada medida de alinhamento, são estimadas funções em que a variável Margem de vitória assume valores lineares, quadráticos e cúbicos ${ }^{57}$. Novamente, ressaltase que os parâmetros referentes à margem de vitória e suas interações com a dummy de

57 Sendo incluídas também suas respectivas interações com a dummy de alinhamento, as variáveis de controle e as dummies de ano. 
alinhamento são omitidos das tabelas para facilitar a visualização dos resultados. O Painel A apresenta os resultados referentes ao alinhamento com os partidos da coligação, ao passo que o Painel B apresenta os resultados referentes ao alinhamento com os partidos da coligação e/ou com os partidos dos ministros ${ }^{58}$.

Analisando-se inicialmente o valor total do financiamento, nota-se que o efeito do alinhamento com os partidos da coligação é positivo e estatisticamente significante nos casos em que a margem de vitória assume valores lineares e cúbicos, mas quando se considera o alinhamento com os ministérios, todas as estimações apresentam parâmetros positivos com significância estatística a no máximo 10\%. No caso dos empréstimos do tipo reembolsável, nota-se resultado semelhante: a dummy de alinhamento com os partidos da coligação presidencial assume valor positivo e estatisticamente significante somente na especificação linear, mas quando a medida de alinhamento passa a contemplar também os partidos dos ministros, todos os parâmetros passam a ser estatisticamente não nulos. Estes resultados, portanto, aqueles apresentados nas Tabelas 20 e 21, qual seja, de que no caso dos estados, o alinhamento com o governo federal parece exercer efeito positivo sobre o montante de financiamento tomado junto ao BNDES.

Também em linha com os resultados apresentados nas Tabelas 20 e 21, o efeito do alinhamento sobre as condições do empréstimo parecem ser nulos. Para a taxa de juros e para o prazo de carência, qualquer que seja a medida de alinhamento, os parâmetros não exibem significância estatística. Já no caso do prazo de amortização os parâmetros também são, em geral, estatisticamente nulos, exceto na especificação cúbica, cujos resultados sugerem prazos maiores para ambas as medidas de alinhamento com o governo federal.

Além dos resultados da abordagem paramétrica do método RDD, os resultados referentes à abordagem não-paramétrica são apresentados na Tabela 23. Conforme pode ser observado, muito embora o efeito do alinhamento partidário sobre o montante total de financiamento seja positivo nas seis estimações, o coeficiente é estatisticamente significante em somente um caso, em particular, referente ao alinhamento com os partidos da coligação e/ou dos ministros. Por sua vez, o efeito do alinhamento sobre o valor do financiamento parece ser mais efetivo no caso dos empréstimos reembolsáveis, dado que das seis estimativas, todas positivas, quatro são estatisticamente significantes. A mais conservadora no caso do alinhamento com os partidos da coligação sugere uma diferença de 1,21 pontos (em valor logaritmizado) entre o valor médio do financiamento obtido por estados cujo governador é alinhado com o governo federal comparativamente a estados cujo chefe de executivo não é. Considerando que, ao redor do threshold, o valor médio dos financiamentos tomados por estados cujos governadores não são alinhados com o governo federal é igual a 18,40, o valor médio dos financiamentos tomados por estados cujos chefes de executivo são alinhados seria da ordem de 19,61 em valor logaritmizado.

Além dos resultados referentes ao valor do financiamento, os três resultados referentes ao alinhamento com os partidos da coligação também sugerem que estados cujos governadores são alinhados com o governo federal tomam financiamentos sujeitos à me-

58 Estes resultados foram obtidos a partir da amostra completa. Resultados referentes às amostras com margens de vitória iguais a $10 \%$ e $20 \%$ ao redor do threshold são apresentados na Tabela B.3 do Apêndice B desta tese. Não são apresentados os resultados referentes à margens de vitória inferiores a $10 \%$ em função do número reduzido ou insuficiente de observações. 


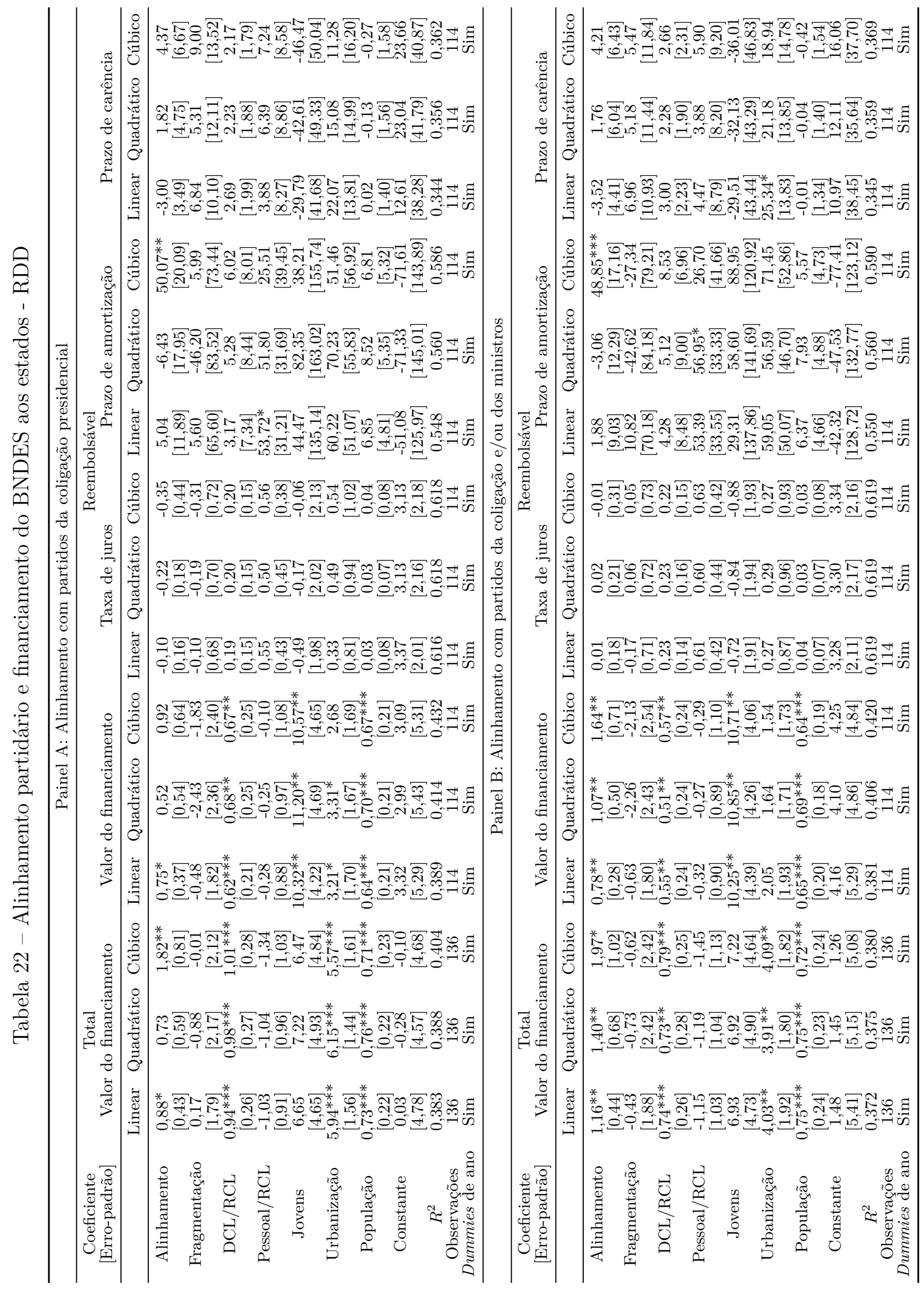

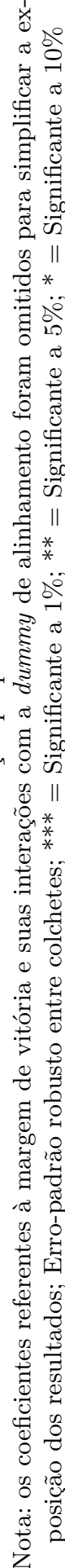


nores taxas de juros ${ }^{59}$. A estimativa mais conservadora sugere uma taxa de juros 0,82 pontos percentuais menor para financiamentos tomados por estados cujos governadores são alinhados com o governo federal. Considerando que ao redor do threshold a taxa média de juros dos financiamentos tomador por estados cujos governadores não são alinhados com o governo federal é da ordem de $2,5 \%$, este valor sugere que a taxa de juros dos financiamentos tomados por estados cujos governadores são alinhados é da ordem de 1,68\%, um valor $32 \%$ inferior.

Os resultados também sugerem que estados cujos governadores são alinhados com o governo federal são beneficiados com maiores prazos de amortização. A estimativa mais conservadora, observada no caso do alinhamento com os partidos da coligação e/ou dos ministros, sugere que estados cujos governadores são alinhados com o governo federal tomam financiamento com 86,67 meses adicionais frente a estados cujos governadores não são alinhados. Considerando que, ao redor do threshold, o prazo médio de amortização dos financiamentos tomados por estados cujos governadores não são alinhados com o governo federal é aproximadamente igual a 65 meses, o prazo dos empréstimos tomados por estados cujos governadores são alinhados seria então aproximadamente igual a 151 meses. Esses resultados parecem ser reforçados pelas Figuras 9, 10, 11, 12 e $13^{60}$, tanto para o alinhamento com os partidos da coligação como com o alinhamento com os partidos da coligação e/ou dos ministros.

\subsubsection{Sobre a validade dos resultados obtidos via RDD}

Conforme mencionado anteriormente, os resultados obtidos via RDD são válidos caso as variáveis de controle não exibam descontinuidade em torno do threshold de interesse. Conforme pode ser visto na Tabela B.4 do Apêndice B desta tese, algumas delas, como a população no caso do alinhamento com os partidos da coligação presidencial, apresentam descontinuidade, o que pode invalidar os resultados anteriormente apresenta$\operatorname{dos}^{61}$. Assim, a exemplo do estudo para os municípios, optou-se por realizar um novo teste em que as variáveis dependentes foram inicialmente regredidas em função das próprias variáveis de controle e, posteriormente, submetidas a novos testes não-paramétricos de descontinuidade. Os resultados desse exercício adicional são apresentados na Tabela B.5 do Apêndice B, e reforçam os resultados apresentados na Tabela 23: os financiamentos do tipo reembolsável parecem ser maiores e sujeitos à menores taxas de juros e maiores prazos de amortização ${ }^{62}$.

Também conforme realizado no caso dos municípios, foram realizados testes visando analisar o comportamento da distribuição da proporção de votos recebidas pelos

59 Muito embora também negativos, os resultados referentes à coligação com os partidos da coligação e/ou dos ministros não são estatisticamente significantes.

60 Também obtidas de forma não-paramétrica via funções de ajuste polinomial local linear e kernel do tipo Triangular.

61 No Apêndice B desta tese também são apresentadas as Figuras B.8, B.9, B.10, B.11, B.12 e B.13 referentes aos testes não-paramétricos de descontinuidade das variáveis de controle das regressões apresentadas na Tabela 22.

62 Neste exercício adicional, o efeito sobre o prazo de carência continua positivo nos seis casos, mas estatisticamente significante em somente dois. Em relação ao montante total do financiamento, as estimativas continuam sendo positivas, mas passam a ser estatisticamente significantes em quatro dos seis casos. 
Tabela 23 - Testes não paramétricos de descontinuidade - estados

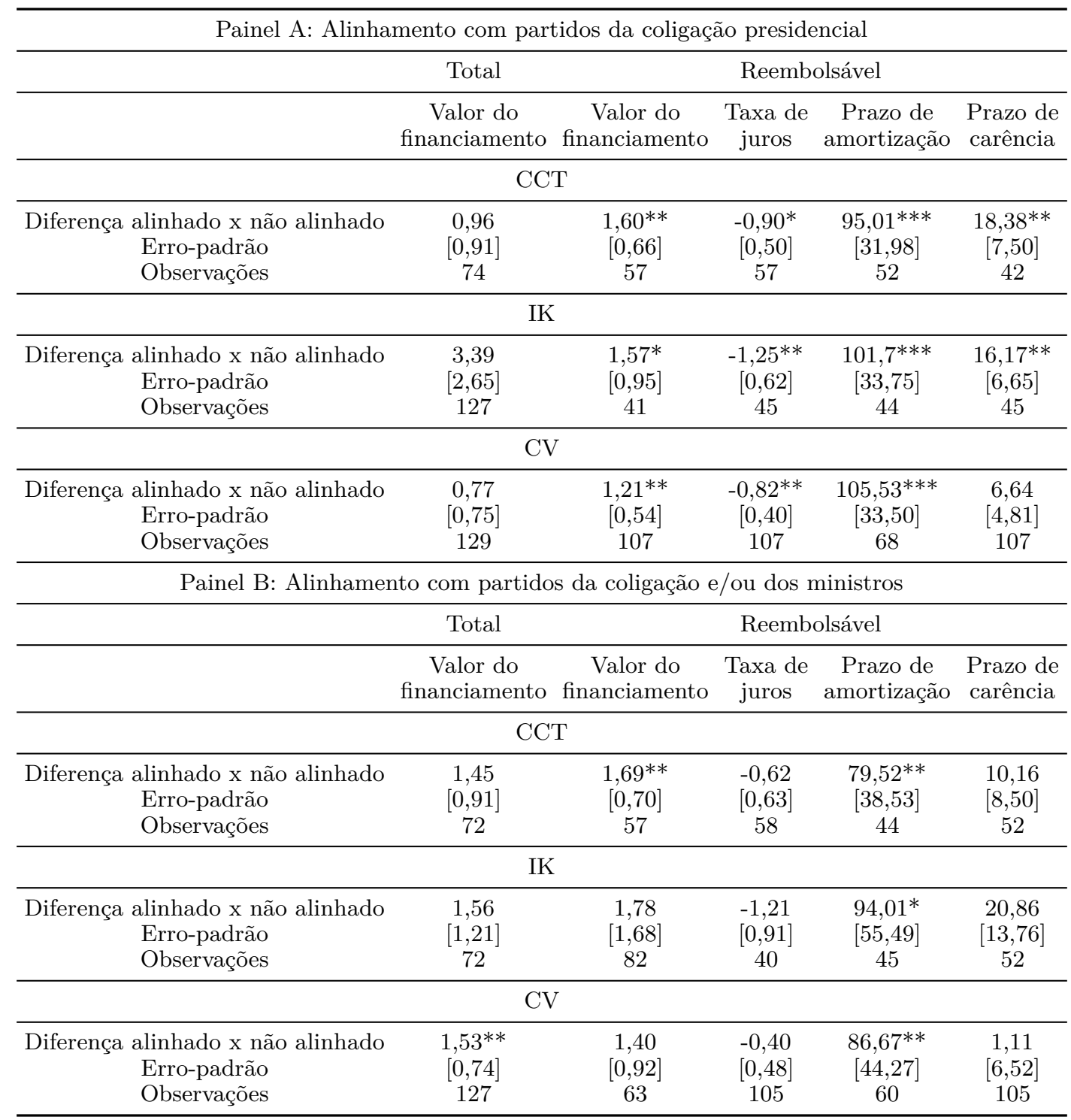

Fonte: elaboração própria

Nota: diferença se refere ao valor da diferença da variável entre unidades alinhadas e não alinhadas em torno da margem de vitória igual a zero; CCT, IK e CV se referem aos métodos de definição da banda (bandwidth) propostos por Calonico, Cattaneo e Titiunik (2014), Imbens e Kalyanaraman (2012) e Ludwig e Miller (2007), respectivamente; ${ }^{* *}=$ Significante a $1 \%{ }^{* *}=$ Significante a $5 \%{ }^{*}=$ Significante a $10 \%$.

candidatos a governador. Novamente, assumindo-se que não haja manipulação desses valores, espera-se que a distribuição seja suave, sem exibir descontinuidades. Nas eleições para governador, contudo, a legislação eleitoral brasileira prevê a realização de segundo turno em todos os estados a não ser que o candidato mais bem votado do primeiro obtenha maioria absoluta dos votos. Assim, seja em primeiro ou em segundo turno, o candidato vencedor é eleito com mais de $50 \%$ dos votos válidos, o que novamente permite definir com exatidão o valor do threshold. Neste caso, o teste contempla os resultados das eleições para governador de 1998, 2002, 2006 e 2010, anos em que foram definidos os governadores presentes na amostra aqui explorada. 


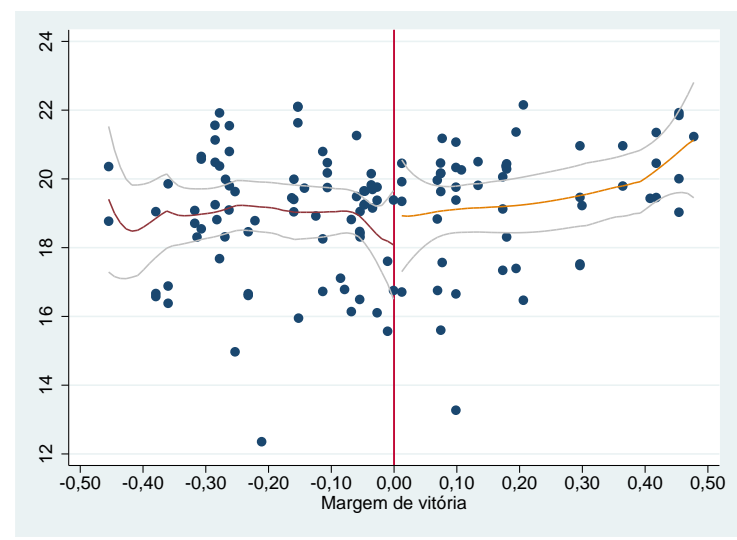

(a) Alinhamento com coligação

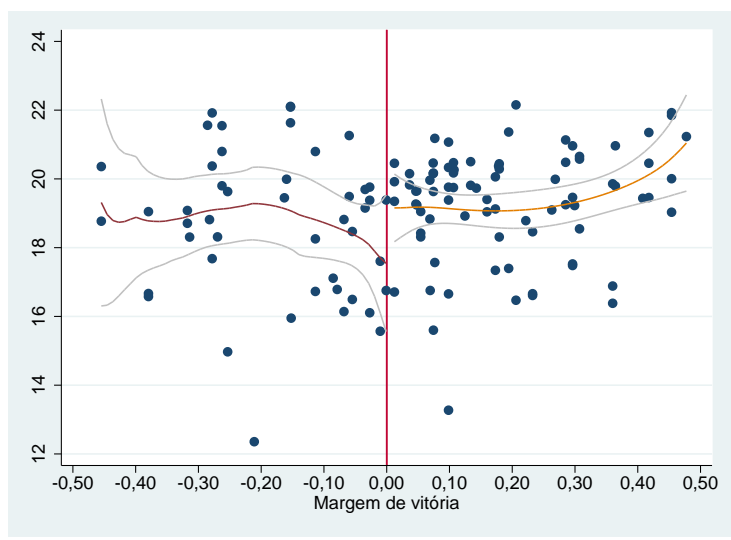

(b) Alinhamento com ministérios

Figura 9 - Valor do financiamento (total) - estados

Fonte: elaboração própria

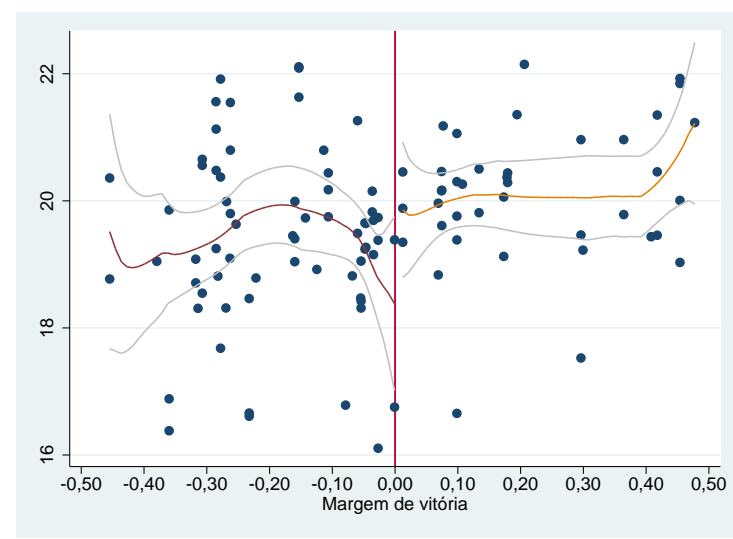

(a) Alinhamento com coligação

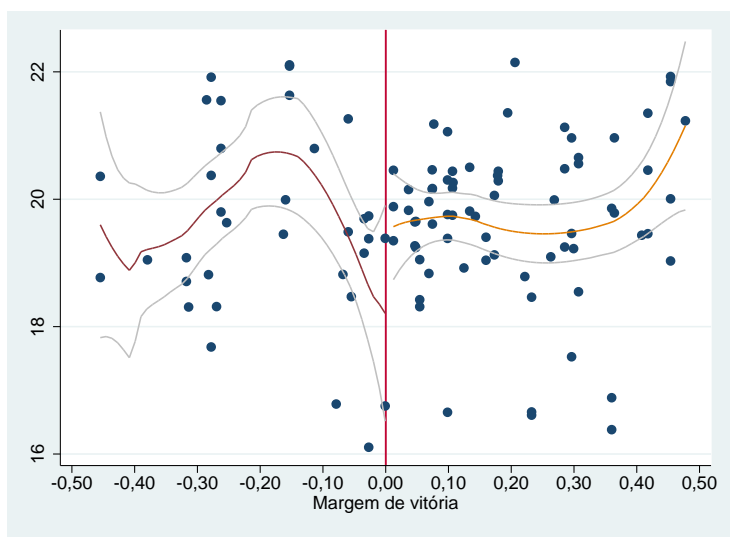

(b) Alinhamento com ministérios

Figura 10 - Valor do financiamento (reembolsável) - estados

Fonte: elaboração própria

A Figura B.14, exposta no Apêndice B, apresenta o histograma e a densidade ${ }^{63}$ da proporção recebida de votos pelo candidato eleito e pelo candidato derrotado normalizados em torno do threshold igual a zero. Assim como no caso dos municípios, os resultados indicam ausência de "quebras" ao redor da margem de vitória igual a zero, garantindo assim confiabilidade aos resultados apresentados referentes aos estados ${ }^{64}$.

\subsection{Considerações finais do capítulo}

O objetivo deste capítulo foi investigar se o alinhamento partidário exerce algum efeito sobre os recursos transferidos entre níveis distintos de governo. Contudo, diferentemente do Capítulo 2, cujo objetivo foi analisar especificamente as transferências governamentais, este capítulo da tese teve como foco um mecanismo indireto de transferências

63 Também obtida via kernel de Epanechnikov.

64 Note que a Figura B.14 também é semelhante à Figura 4 de McCrary (2008), o que fortalece o resultado de densidade contínua. 


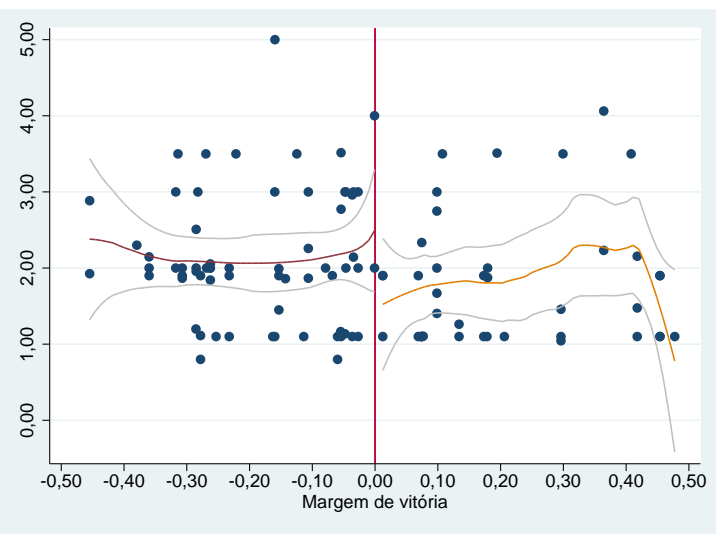

(a) Alinhamento com coligação

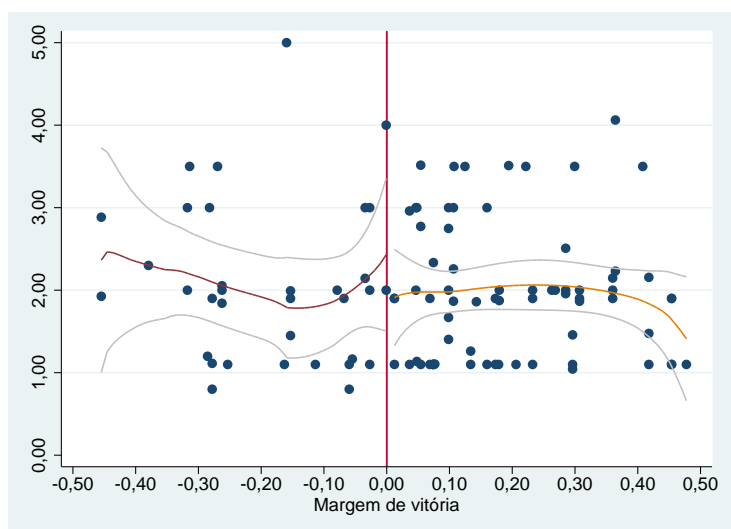

(b) Alinhamento com ministérios

Figura 11 - Taxa de juros - estados

Fonte: elaboração própria

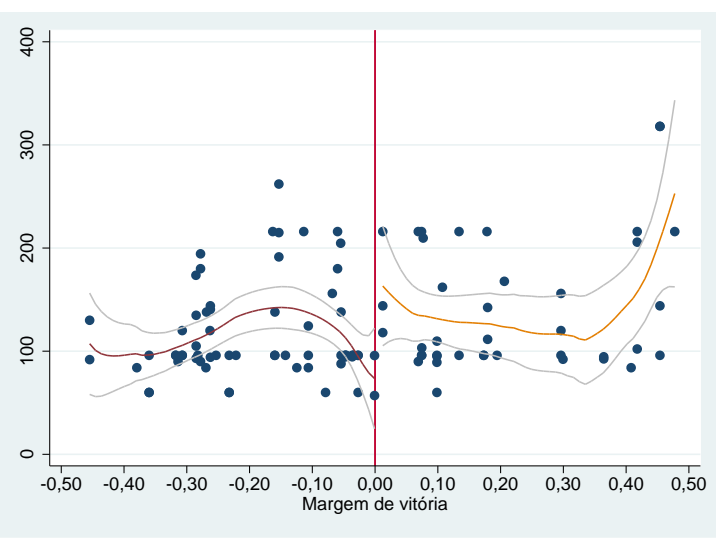

(a) Alinhamento com coligação

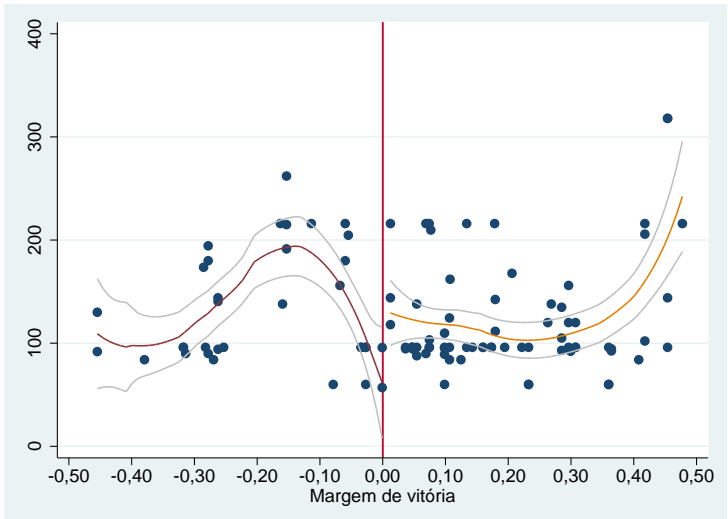

(b) Alinhamento com ministérios

Figura 12 - Prazo de amortização - estados

Fonte: elaboração própria

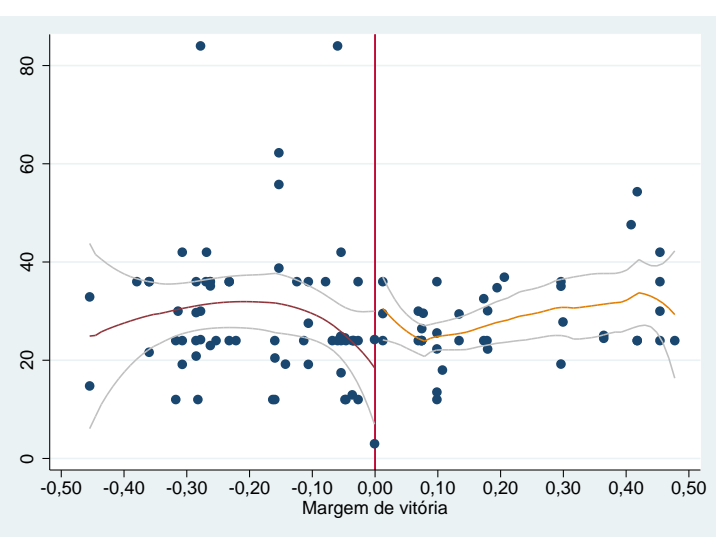

(a) Alinhamento com coligação

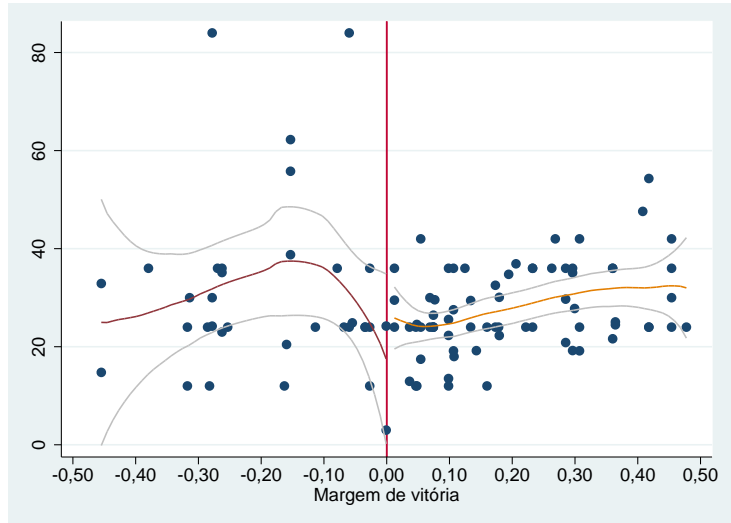

(b) Alinhamento com ministérios

Figura 13 - Prazo de carência - estados

Fonte: elaboração própria 
de recursos, qual seja, os financiamentos oficiais concedidos pelo BNDES aos governos estaduais e municipais do país. Neste capítulo, analisou-se o efeito do alinhamento não só sobre o montante do financiamento, mas também sobre as condições de amortização, em particular, taxas de juros e prazos de amortização e de carência.

Os resultados obtidos sugerem que o efeito do alinhamento parece nulo no caso dos municípios, isto é, a municípios alinhados com o governo federal parecem não estar associados empréstimos de maior montante nem tomados em melhores condições de devolução. Contudo, os resultados sugerem que o efeito do alinhamento parece se dar em um estágio anterior, qual seja, o da solicitação dos recursos. Neste caso, os resultados sugerem que municípios alinhados com o governo federal apresentam maior probabilidade de solicitação de financiamento junto ao BNDES comparativamente aos municípios não alinhados.

Para os estados, por sua vez, os resultados são distintos, pois indicam que estados cujos governadores são alinhados com o governo federal recebem empréstimos de maior montante comparativamente a estados cujos governadores não são alinhados. Além deste resultado, foram também encontradas evidências de que estados alinhados com o governo federal também tomam financiamentos com melhores condições de devolução, em particular, sujeitos à menores taxas de juros e maiores prazos de amortização. Assim, esses resultados sugerem que o efeito do alinhamento parece se dar de forma diferente entre estados e municípios alinhados com o governo federal: se para os estados o efeito parece se dar diretamente sobre o financiamento, para os municípios o efeito parece se dar via maior probabilidade de solicitação (e atendimento) do financiamento.

Os resultados apresentados neste capítulo estão em linha com alguns estudos mencionados na revisão da literatura - em particular, com o estudo de Carvalho (2014), que também versa sobre o BNDES - que sugerem que a atuação de bancos públicos pode estar sujeita à influência política. Tomados em conjunto com os resultados apresentados no Capítulo 2 desta tese, as evidências aqui encontradas parecem corroborar a hipótese de que o alinhamento partidário com níveis superiores de governo parece gerar benefícios às unidades inferiores, seja via transferências governamentais, seja via empréstimos subsidiados via bancos públicos. Contudo, estes resultados não permitem afirmar categoricamente que o BNDES esteja sendo gerido pelo governo federal de forma oportunista visando beneficiar os municípios ou estados politicamente alinhados (em detrimento dos não alinhados), dado que outros fatores podem explicar este resultado.

Em primeiro lugar, e possível, por exemplo, que os partidos incumbentes do governo federal façam uma maior divulgação dos financiamentos providos pelo BNDES aos estados e municípios alinhados em função da maior facilidade de comunicação entre os membros do próprio partido, o que pode aumentar a probabilidade de solicitação sem implicar em provisão de financiamento com viés deliberadamente partidário. Esta explicação parece encontrar respaldo no caso dos resultados referentes aos municípios para os quais, conforme mencionado anteriormente, encontrou-se um efeito positivo do alinhamento sobre a probabilidade de solicitação de financiamento junto ao banco. Uma vez submetido, o projeto passa a tramitar dentro da estrutura administrativa do BNDES que conta com critérios técnicos de análise que pouco provavelmente abrem margem para outro tipo de influência. 
Em segundo lugar, a base de dados explorada neste artigo contempla, à exceção do ano de 2002, anos em que o mesmo partido esteve na chefia do governo federal ${ }^{65}$. Assim, é possível que os resultados apresentados não sejam explicados pelo alinhamento com o governo federal de forma geral, mas sim especificamente pelo alinhamento com partido que tem gerido o governo federal ao longo dos últimos anos. Assim, os resultados apresentados neste estudo, apesar de relativamente consistentes entre os diferentes exercícios econométricos empregados, devem ser interpretados com cautela. De qualquer forma, os exercícios realizados ao longo deste capítulo procuram trazer novas evidências referentes à atuação do BNDES que, conforme mencionado anteriormente, exerce papel de grande relevância no desenvolvimento econômico do país.

65 No caso, o Partido dos Trabalhadores. 


\section{Condições econômicas e desempenho eleitoral: novas evidên- cias a partir de um quase-experimento}

\subsection{Introdução}

É amplamente conhecido que a maior parte da energia elétrica produzida e consumida no Brasil é gerada por usinas hidrelétricas. Hoje, segundo a ANEEL, mesmo após o recente fortalecimento de fontes alternativas como solar, eólica e biomassa, as usinas hidrelétricas continuam sendo responsáveis por $90 \%$ do total da energia elétrica consumida no país.

Entre julho de 2001 e fevereiro de 2002, após um período de forte estiagem e consequente queda do nível dos reservatórios das usinas hidrelétricas, o governo federal brasileiro instituiu um amplo programa de racionamento de energia elétrica visando evitar interrupções no fornecimento - esse episódio ficou popularmente conhecido como "Crise do apagão". Em decorrência da instituição do programa, que estabelecia reduções significativas no consumo de energia por diversos tipos de consumidores, houve piora não desprezível de diversos indicadores de produção, renda e emprego, consequências essas que eventualmente exerceriam algum efeito sobre a popularidade do governo. Muito embora não seja possível afirmar que a instituição do racionamento tenha sido sua única razão, fato é que nas eleições presidenciais de outubro de 2002, o candidato da situação, José Serra, do PSDB, não foi eleito.

O objetivo deste estudo é revisitar uma literatura bastante tradicional conhecida como economic voting, que procura analisar como o desempenho eleitoral de candidatos incumbentes é influenciada pelo desempenho da economia. A hipótese central desta literatura é que melhores condições econômicas tendem a favorecer o desempenho nas urnas dos candidatos da situação. Contudo, argumenta-se neste estudo que a mensuração correta desta relação pode ser dificultada em função de um possível viés de endogeneidade entre condições econômicas e desempenho eleitoral, influenciada, entre outros, pelas preferências do eleitorado. Esta relação pode ser estimada corretamente caso seja possível explorar os efeitos de um evento exógeno que exerça influência sobre as condições econômicas e que não tenha relação com fatores não observáveis que afetem a decisão de voto dos eleitores.

Inspirado no trabalho de Waldinger (2010), este estudo faz uso da combinação das metodologias Diferenças-em-Diferenças e Variáveis Instrumentais, por meio da qual são explorados dados em nível municipal dos estados de São Paulo e Paraná, os quais fizeram e não fizeram, respectivamente, parte das regiões abrangidas pelo programa. Em particular, procura-se demonstrar que a instituição do programa de racionamento de fato exerceu efeito negativo sobre o consumo de energia elétrica, analisando-se separadamente a redução entre consumidores residenciais, comerciais e industriais. A partir desta evidência, em um primeiro estágio, procura-se mensurar qual foi o efeito da instituição do racionamento sobre as condições de renda e emprego dos municípios abrangidos pelo programa. Por fim, no segundo estágio, o estudo procura mensurar como os eleitores traduziram esta piora das condições econômicas em sua decisão de voto. Em particular, este estudo 
avalia o desempenho do candidato da situação à presidência da República nos municípios paulistas relativamente aos paranaenses nas eleições presidenciais de 1998 e 2002 . A ideia do estudo, portanto, é explorar a escassez de chuvas observada entre o final de 2000 e o início de 2001 como uma fonte exógena de variação, assemelhando-se portanto a um quase-experimento.

Os resultados obtidos indicam que a instituição do programa de racionamento, que de fato reduziu significativamente o consumo de energia elétrica, ocasionou também piora de alguns indicadores econômicos dos municípios paulistas (grupo de tratamento) relativamente aos municípios paranaenses (grupo de controle). Por fim, os resultados do segundo estágio não só corroboram a percepção de que melhores condições econômicas são realmente benéficas ao desempenho eleitoral dos candidatos incumbentes, mas que esse efeito pode ter sido subestimado pela literatura. Em particular, os resultados obtidos por meio do método aqui empregado sugerem que o efeito de condições econômicas sobre a proporção de votos recebidas pelo candidato da situação é significativamente maior do que o resultado sugerido por estimações tradicionais do tipo OLS.

Este trabalho está dividido da seguinte forma: a seção 4.2 apresenta uma breve revisão da literatura, ao passo que a seção 4.3 apresenta algumas características do programa de racionamento instituído no Brasil entre 2001 e 2002. A seção 4.4, por sua vez, apresenta a estratégia empírica e discute os dados explorados neste capítulo. Na seção 4.5, são apresentados e discutidos os resultados das estimações e por fim, a seção 4.6 apresenta as considerações finais deste capítulo.

\subsection{Revisão da literatura}

Conforme mencionado anteriormente, o objetivo deste estudo é analisar como condições econômicas influenciam a decisão de voto dos eleitores, tomando o racionamento de energia elétrica instituído no Brasil entre 2001 e 2002 como uma fonte exógena de variação. Neste sentido, este estudo interage com duas literaturas relacionadas, mas diferentes. A primeira delas, já bastante tradicional, avalia o efeito de condições econômicas sobre a decisão de voto dos eleitores. A segunda, por seu turno, avalia o efeito de eventos exógenos sobre o comportamento do eleitorado.

Em relação à primeira, há uma ampla e bem conhecida literatura que associa decisão dos eleitores ao comportamento da economia. A partir dos trabalhos seminais de Key (1966), Kramer (1971), Ferejohn (1974), Fair (1978), Fiorina (1981) e Lewis-Beck (1988), entre outros, vários estudos, têm procurado analisar como eleitores favorecem ou penalizam policymakers com base em condições econômicas. A conclusão geral (mas não unânime) desta literatura é que os eleitores de fato favorecem incumbentes caso os mesmos tenham promovido condições econômicas favoráveis durante seu governo.

Entre os estudos mais recentes nesta área, muito embora Brender e Drazen (2008) tenham explorado um painel de países ${ }^{66}$, a maioria têm tido como foco unidades regionais e locais de países específicos. Em particular, o foco de tais estudos têm variado quanto

66 E encontrado evidências de que maiores níveis de crescimento econômico aumentam as chances de reeleição do chefe do executivo nacional especialmente em países em desenvolvimento e nas denominadas "novas democracias". 
ao nível de governo das eleições (variando entre eleições para o governo federal, regional ou local), quanto ao nível de mensuração/desagregação do desempenho eleitoral (que pode ser mensurado não só nos mesmos níveis mencionados anteriormente, mas também pode ser mensurado em níveis mais detalhados de uma dada localidade, como os equivalentes às seções e zonas eleitorais brasileiras, por exemplo ${ }^{67}$ ), quanto ao tipo de eleição (para o executivo ou para o legislativo) e quanto ao nível de mensuração do desempenho econômico (também variando entre nacional, regional e local). Assim, por exemplo, há estudos que analisam a influência de fatores econômicos nacionais sobre o sucesso eleitoral de incumbentes ao executivo nacional mensurando o desempenho eleitoral ao nível municipal, ao mesmo tempo em que há estudos que analisam a influência de fatores econômicos locais sobre o desempenho de incumbentes ao legislativo nacional mensurados em nível local ou então, sobre o desempenho de incumbentes ao executivo local (neste caso, o desempenho eleitoral é naturalmente mensurado ao nível local). Há também estudos que analisam a influência conjunta dos indicadores econômicos mensurados em diferentes níveis de governo.

Remmer e Gelineau (2003), por exemplo, analisam o efeito de condições econômicas nacionais (inflação e desemprego) e provinciais (desemprego) sobre o desempenho do partido incumbente eleições argentinas para os cargos de governador e deputados das províncias e para o cargo de deputados nacionais. Os resultados indicam que há um efeito negativo e estatisticamente significante do desemprego nacional sobre o sucesso eleitoral dos dois primeiros cargos, e um efeito negativo e estatisticamente significante da inflação nacional sobre os dois últimos cargos. Contudo, o efeito da taxa de desemprego das províncias é estatisticamente nulo qualquer que seja o cargo em questão, mesmo no caso das eleições para governador das províncias.

Gelineau e Belanger (2005), por sua vez, analisam as eleições para o executivo federal e provincial do Canadá avaliando o desempenho eleitoral ao nível das províncias e também encontram evidências de que melhores condições econômicas exercem efeitos positivos sobre a performance eleitoral. Resultados semelhantes, isto é, que corroboram esta relação, são apresentados por Auberger e Dubois (2005), que analisam as eleições para o parlamento francês avaliando o desempenho eleitoral em nível regional, e por Smeets e Warzynski (2006), que analisam as eleições para o parlamento polonês avaliando o desempenho eleitoral mensurado ao nível regional.

Mais recentemente, o estudo realizado por Cerda e Vergara (2007) explorou um painel de municípios chilenos visando investigar como condições econômicas nacionais, regionais e locais afetam a proporção de votos recebidas pelo candidato incumbente nas eleições presidenciais de 1989, 1993 e 1999. Em particular, os resultados obtidos sugerem que o desemprego em nível nacional e em nível regional exercem efeito negativo sobre o desempenho eleitoral (mensurado ao nível municipal), muito embora o efeito do desemprego em nível local seja nulo.

Veiga e Veiga (2010), por seu turno, exploram um painel de municípios portugueses visando analisar o efeito de condições econômicas tanto nacionais como locais sobre o desempenho eleitoral nas eleições para o legislativo federal. Os autores encontram resultados que sugerem que melhores condições econômicas nacionais (menor inflação, menor

\footnotetext{
67 Contudo, artigos com esse nível de desagregação são raros.
} 
desemprego e maior produto agregado) aumentam a proporção de votos recebidos pelo partido incumbente $^{68}$ nos municípios do referido país, mas esse efeito não é o mesmo no caso dos indicadores econômicos locais. Em particular, o efeito das condições de emprego e salário locais é estatisticamente nulo. Em outro estudo também referente às eleições portuguesas com dados em nível municipal, mas analisando especificamente as eleições para o chefe do executivo local, Martins e Veiga (2013) encontram evidências de que condições econômicas nacionais exercem efeitos significativos sobre a performance eleitoral, especialmente quando o chefe do executivo local é politicamente alinhado com o chefe do executivo nacional. Esse último resultado sugere, portanto, que os eleitores podem punir indiretamente o chefe do executivo nacional via penalização do chefe do executivo local caso ambos sejam do mesmo partido político. Curiosamente, o efeito das condições econômicas locais sobre a performance dos chefes do executivo local parece ser mais tênue comparativamente ao efeito das condições econômicas agregadas/nacionais.

Além das anteriormente mencionadas, outra referência que versa sobre o problema em questão é o estudo realizado por Elinder (2010), que tem como foco o efeito das condições econômicas regionais e locais (em particular, renda e desemprego) sobre as eleições para o parlamento da Suécia, mensurando a performance eleitoral ao nível municipal. Os resultados obtidos indicam que as condições econômicas exercem efeito sobre o desempenho eleitoral, em especial, o desemprego, dado que o efeito da renda regional e local parece ser mais sensível às diferentes especificações exploradas pelo autor. Em um estudo realizado anteriormente também referente às eleições parlamentares suecas, Jordahl (2006) analisam o efeito de condições econômicas sobre as decisões de voto, mas neste caso, realizam entrevistas e avaliam, portanto, escolhas ao nível dos indivíduos. Os resultados também confirmam a percepção de que melhores condições econômicas melhoraram a performance eleitoral dos incumbentes ${ }^{69}$.

Este estudo procura contribuir com a literatura ao explorar os efeitos de um evento exógeno sobre a decisão dos eleitores, assemelhando-se portanto a um quase-experimento. De fato, boa parte da literatura recente que versa sobre decisões de voto dos eleitores tem ido nesta direção. Healy e Malhotra (2009), por exemplo, exploram um painel de municípios americanos entre 1988 e 2004 visando investigar como os eleitores avaliam políticas federais voltadas à gestão de desastres naturais ${ }^{70}$, separando-as entre preventivas (ou seja, realizadas antes da ocorrência do desastre visando evitá-lo ou então evitar ou minimizar suas consequências) e de tratamento (ou seja, as realizadas após a ocorrência do evento e que servem para minimizar as consequências sobre os já afetados). Os autores encontram evidências de que os eleitores americanos são indiferentes em relação a gastos públicos de perfil preventivo, mas avaliam positivamente governantes que executam gastos com perfil de tratamento ex-post, mesmo tendo os autores encontrado evidências de que os gastos preventivos diminuem as consequências dos desastres. Uma possível explicação para esse resultado, segundo os autores, é que políticas preventivas têm perfil coletivo

68 Isto é, o partido do Primeiro Ministro.

69 Além da influência de fatores econômicos sobre a decisão dos eleitores, há outra corrente da literatura que procura analisar o efeito fatores não puramente econômicos sobre a decisão dos eleitores. Grose e Oppenheimer (2007) e Karol e Miguel (2007), por exemplo, encontram evidências de que mortes de militares nos conflitos da guerra do Iraque prejudicam as chances de reeleição nas disputas americanas para o legislativo e para a presidência da República, respectivamente.

70 Terremotos, furacões e inundações, entre outros. 
e de benefícios difusos entre os agentes, ao passo que as políticas de tratamento ex-post são normalmente caracterizadas por transferências diretas, beneficiando específica e diretamente os afetados pelos desastres. Ainda na linha de trabalhos que analisam o efeito de eventos naturais sobre a decisão dos eleitores e o sucesso eleitoral dos incumbentes, Malhotra e Kuo (2008) estudam quais governantes os eleitores americanos responsabilizam após os danos causados pela passagem do furacão Katrina, encontrando evidências de que o partido político dos governantes e o partido com o qual os eleitores se identificam exercem efeito estatisticamente significante sobre a atribuição da responsabilidade: eleitores simpatizantes do partido democrata atribuem maior responsabilidade a governantes republicanos, assim como simpatizantes do partido republicano atribuem maior responsabilidade a governantes democratas.

Ainda explorando o efeito de eventos exógenos sobre o comportamento dos eleitores, Artes (2014) analisa o efeito da ocorrência de chuvas em dias de eleição sobre abstenção dos eleitores espanhóis. Analisando a performance dos partidos nas eleições nacionais usando dados em nível municipal, o autor encontra evidências de que uma menor ocorrência de chuvas aumenta a quantidade de eleitores que efetivamente vão às urnas. Além disto, também encontra evidências de que apesar de uma maior presença do eleitorado penalizar os partidos conservadores, não são os partidos de esquerda os beneficiados, mas sim os pequenos. Além deste resultado, o autor também encontra evidências de que condições econômicas exercem influência sobre o comportamento dos eleitores espanhóis: maiores níveis de desemprego municipal aumentam a presença nas urnas, aumentam os votos para partidos conservadores e diminuem os votos para partidos de esquerda. De forma similar à Artes (2014), Persson, Sundell e Öhrvall (2014) também analisam como a presença nas urnas é influenciada pela ocorrência de chuvas. Analisando um painel de municípios suecos entre 1970 e 2010, os resultados obtidos pelos autores indicam que chuvas em dias de eleição exercem efeito nulo sobre a decisão dos eleitores suecos a ir às urnas ou não, diferentemente portanto do resultado obtido por Artes (2014).

Finalmente, cabe fazer menção ao estudo recente de Franck (2016), que encontra evidências de que choques de renda podem exercer efeito sobre própria a sustentabilidade de regimes políticos. Ao explorar dados referentes ao desempenho eleitoral de candidatos ao parlamento francês ao final do século XIX ${ }^{71}$, o estudo também considera a ocorrência de chuvas como fonte exógena de variação das condições econômicas e encontra evidências de que maiores níveis de renda aumentam a proporção de votos recebida por candidatos de partidos republicanos, justamente os que à época davam suporte ao governo incumbente. Conforme será discutido em sequencia, o estudo proposto neste capítulo guarda semelhanças com o estudo supramencionado.

\subsection{O programa de racionamento de 2001-2002}

Conforme mencionado anteriormente, a maior parte da energia elétrica produzida e consumida no Brasil é gerada por meio de usinas hidrelétricas. À época do racionamento, aproximadamente $95 \%$ da energia elétrica produzida no país era gerada via fonte

$\overline{71}$ Durante a chamada Terceira República. 
hidráulica, ao passo que as usinas termelétricas e nucleares, respondiam então por apenas $4 \%$ e $1 \%$ da geração, respectivamente.

A crise energética de 2001 não foi a primeira ocorrida no país ${ }^{72}$. Contudo, o racionamento instituído no Brasil em 2001 e 2002 foi singular: em um levantamento bastante interessante realizado por Meier (2005), em que são estudadas diversas experiências postas em práticas em diversos países ${ }^{73}$, o programa de racionamento instituído no Brasil entre 2001 e 2002 se destaca por ter sido o maior não só quanto à sua duração, mas também quanto à sua abrangência e quanto à redução de consumo de energia.

No início do ano de 2001, a capacidade de geração de energia por parte das usinas hidrelétricas brasileiras sofreu forte redução em função da queda dos níveis dos reservatórios de água. Além disto, à época, a capacidade de distribuição entre as diferentes regiões do país não permitia que a energia gerada em uma região fosse plenamente transferidas para outras dado que as usinas e as centrais de distribuição existentes ao longo do território não estavam suficientemente conectadas. Nesse contexto, o governo federal foi visto como um dos principais responsáveis pelo problema em função de baixos investimentos realizados no sistema nos anos que antecederam o racionamento.

O racionamento instituído à época pode ser visto a partir de duas óticas. Pelo lado da oferta, questões climáticas explicam o baixo nível dos reservatórios. Entre o fim de 2000 e o início de $2001^{74}$, o nível de precipitação foi bastante inferior ao normal, atingindo então o menor nível em 40 anos (BARDELIN, 2004). Por outro lado, o nível de precipitação nos estados da região Sul foi bastante favorável ao longo do segundo semestre de 2000, elevando significativamente o nível dos seus reservatórios - a título de ilustração, no início de 2001, os reservatórios desta região estavam com praticamente $100 \%$ de sua capacidade. Ainda pelo lado da oferta, o sistema de distribuição de energia até então existente apresentava limitações estruturais que não permitiam que a energia gerada na região Sul fosse plenamente transferida para as demais regiões. A existência de alguns entraves ambientais também impediu a operação de algumas unidades geradoras ${ }^{75}$. Por fim, Bardelin (2004) também menciona que, anteriormente ao racionamento, o governo federal havia tomado algumas iniciativas visando ampliar a produção de energia via usinas termelétricas, mas que na prática, acabaram por não equacionar o problema e evitar a instituição do programa.

Pelo lado da demanda, por sua vez, fatores estruturais levaram a um crescimento significativo nos anos anteriores ao racionamento, chegando inclusive a reverter as condições vigentes dado que até então, o crescimento da demanda por energia jamais havia superado a capacidade de geração do sistema (COSTA; GERARD, 2015). Conforme Bardelin (2004), o "Plano Decenal de Expansão do Sistema Elétrico" já previa alto risco de racionamento em 2000, que efetivamente não chegou a ser instituído pelas chuvas favoráveis ocorridas no segundo semestre do ano anterior. Ainda segundo Bardelin (2004),

\footnotetext{
72 Ao longo dos anos 50 e 60, foram instituídos cortes de energia nos estados de São Paulo, Rio de Janeiro e Minas Gerais. Algumas décadas depois, já nos anos 80, as regiões Sul e Sudeste também sofreram problemas quanto à provisão de energia elétrica em função, entre outros fatores, da escassez de chuvas.

73 Como EUA, Japão, Austrália e Suécia, entre outros.

74 Em boa parte do país, o período considerado chuvoso vai de novembro/dezembro de um ano até fevereiro/março do ano seguinte. Durante o restante do ano, as chuvas ocorrem de forma irregular.

75 Conforme pode ser visto em < http://veja.abril.com.br/idade/blecaute/lei/porque.html $>$.
} 
desde 1998 o nível dos reservatórios da região Sudeste e Centro-Oeste já vinha registrando queda.

Visando evitar blecautes no sistema elétrico, em 04 de junho de 2001, o governo federal instituiu o regime de racionamento, segundo o qual foram instituídas metas de redução de consumo de energia que perdurariam até fevereiro de 2002, ou seja, até que os reservatórios das regiões afetadas pelo racionamento pudessem se recompor.

O racionamento se deu tanto por meio da definição de cotas obrigatórias como também por meio de incentivos para a redução do consumo. Pelo lado da obrigatoriedade, para os consumidores residenciais, comerciais e industriais de baixa tensão dos estados das regiões Sudeste, Centro-Oeste e Nordeste, a cota era definida como consumo de no máximo $80 \%$ da média consumida entre maio e julho de $2000^{76}$, embora a cota tenha sido mais branda para esses mesmos consumidores do estado do Mato Grosso do Sul (cota de $90 \%$ ao invés de $80 \%$ ). Para os consumidores comerciais e industriais de média e alta tensão, a cota variava entre $75 \%$ e $85 \%$ do consumo médio dos meses de maio, junho e julho de 2000, havendo variação de acordo com o ramo de atividade. Os estados do Pará, Tocantins e de parte do Maranhão foram incluídos no racionamento posteriormente, a partir de 01 de julho de 2001, com cotas diferentes das aplicadas nos estados do Sudeste, Centro-Oeste e demais estados do Nordeste. Adicionalmente, limites ainda mais restritivos foram instituídos para iluminação pública e consumo de energia em repartições públicas.

Pelo lado dos incentivos, houve a instituição de bônus para usuários que consumissem menos do que a cota estabelecida e de multas em caso de consumo acima que, caso fossem recorrentes, poderiam levar ao corte temporário de energia. Já consumidores considerados pequenos (média máxima de 100kWh mensais) ficavam isentos das penalidades do racionamento. O racionamento também contemplou redução temporária de impostos sobre lâmpadas fluorescentes ${ }^{77}$, as quais foram inclusive distribuídas pelo governo federal à famílias de baixa renda, aumento temporário de impostos sobre chuveiros, aquecedores elétricos e lâmpadas incandescentes ${ }^{78}$, assim como a realização intensas campanhas via jornais, rádio e TV e por meio das próprias contas de energia. Diante do racionamento, muitas empresas optaram por adquirir geradores movidos a óleo diesel para viabilizar a continuidade de suas atividades, algo que foi inclusive incentivado pelo governo via redução de impostos ${ }^{79}$.

Muito embora o racionamento instituído no Brasil entre 2001 e 2002 tenha sido bastante abrangente e rigoroso, existem poucas referências que analisam seus efeitos. Uma delas é o estudo realizado por Costa e Gerard (2015), que encontra evidências de que a redução do consumo de energia elétrica residencial foi não só significante, mas também permanente, isto é, perdurou mesmo após o final do racionamento. Segundo os autores, a queda do consumo de longo prazo foi da ordem de aproximadamente $50 \%$ da redução de curto prazo, isto é, da redução observada durante a vigência do racionamento. Em

76 Para considerar efeitos sazonais, as metas para dezembro de 2001 foram redefinidas como $80 \%$ da média consumida entre dezembro de 2000 e fevereiro de 2001.

77 Ver, por exemplo, <http://www1.folha.uol.com.br/folha/dinheiro/ult91u23083.shtml>.

78 Ver, por exemplo, Decreto 3.827, de 21 de maio de 2001 e <http://www1.folha.uol.com.br/folha/ dinheiro/ult91u23090.shtml>.

79 Ver, por exemplo, <http://www1.folha.uol.com.br/folha/dinheiro/ult91u23092.shtml> e <http:// www.valor.com.br/arquivo/1000019987/geradores-ajudam-a-weg-a-aumentar-seu-resultado-em-59>. 
particular, a redução do consumo de energia não se deveu à substituição de eletrodomésticos antigos por mais novos e mais eficientes ${ }^{80}$, mas sim à mudanças de hábito dos consumidores $^{81}$. Segundo Bardelin (2004), houve até mesmo queda das vendas de eletrodomésticos em função, em partes, da queda da renda decorrente do próprio racionamento. Desta forma, Costa e Gerard (2015) encontram evidências de que mesmo políticas de curto prazo e de duração conhecida ex ante podem exercer efeitos permanentes sobre a decisão dos agentes.

Algumas evidências anedóticas ajudam a contextualizar a avaliação do governo diante da instituição do programa de racionamento. Segundo a pesquisa realizada pelo instituto Sensus em parceria com a Confederação Nacional do Transporte (CNT), em pesquisa realizada em abril de $2001^{82}$, quando solicitados a responder a questão "As autoridades vem alertando a população de que o país está correndo sério risco de falta de energia elétrica. Você acha que esse perigo é verdadeiro, ou você acha que está havendo muito exagero?", $55,4 \%$ dos respondentes responderam que "O perigo é verdadeiro". Em pesquisa realizada em maio de $2001^{83}$, quando solicitados a responder a questão "A partir do mês de junho teremos racionamento de energia no Brasil. Na sua opinião, qual é o principal motivo para essa crise de energia elétrica?", a alternativa "Incompetência do governo" foi selecionada por $42,2 \%$, ao passo que "Falta de chuvas" e "Falta de recursos do governo para investimentos" foi selecionada por $27,4 \%$ e $14,4 \%$ dos respondentes. Ainda neste mesmo boletim, quando solicitados a responder "O que o senhor(a) mais teme na crise de energia do país?", as alternativas "Aumento da violência" e "Aumento do desemprego" foram as mais frequentes, tendo sido selecionadas por $53,1 \%$ e $25 \%$ dos respondentes, respectivamente. Ainda segundo esta edição da pesquisa, a avaliação positiva do Presidente da República caiu de $29,7 \%$ para 22,1\%. Já a avaliação regular passou de $38,9 \%$ para $36,2 \%$ e a negativa subiu de $27,9 \%$ para $37,1 \%$. Em pesquisa realizada em junho de $2001^{84}$, por sua vez, quando novamente confrontados com a pergunta "O que o senhor(a) mais teme na crise de energia do país?" feita na pesquisa anterior, houve uma redução da participação da alternativa "Aumento da violência" de 53,1\% para 47,1\%, ao passo que a alternativa "Aumento do desemprego" passou de $25 \%$ para $35,1 \%$. Por fim, segundo a pesquisa realizada em setembro de $2001^{85}$, quando solicitados a responder a questão "Na sua opinião, o racionamento de energia está afetando ou não está afetando o desenvolvimento do país", a resposta "Está afetando muito" foi selecionada por 57,8\% dos respondentes. Ademais, evidências anedóticas também sugerem que o setor industrial e o mercado de trabalho dos municípios do estado de São Paulo, abrangidos pelo racionamento, sofreram importantes consequências negativas ${ }^{86}$. Assim, estas evidências sugerem

80 Exceção à substituição de lâmpadas incandescentes por lâmpadas fluorescentes de rosca, que à época ocorreu de forma bastante generalizada pelos consumidores.

81 Como a menor utilização de freezers e de aparelhos de ar-condicionado e a utilização de chuveiro elétrico na posição "Verão" ao invés da posição "Inverno".

82 Pesquisa de Opinião Pública Nacional - Rodada 36 - 13 a 19 de abril de 2001.

83 Pesquisa de Opinião Pública Nacional - Rodada 37 - 18 a 24 de maio de 2001.

84 Pesquisa de Opinião Pública Nacional - Rodada 38 - 15 a 21 de junho de 2001.

85 Pesquisa de Opinião Pública Nacional - Rodada 41 - 14 a 20 de setembro de 2001.

86 Ver, por exemplo, <http://www1.folha.uol.com.br/folha/dinheiro/ult91u22894.shtml>, <http:// www1.folha.uol.com.br/folha/dinheiro/ult91u22864.shtml>, <http://www1.folha.uol.com.br/folha/ dinheiro/ult91u22846.shtml>, < http://www1.folha.uol.com.br/folha/dinheiro/ult91u23023.shtml>, <http://www1.folha.uol.com.br/folha/dinheiro/ult91u23065.shtml> e <http://www1.folha.uol.com. 
que o racionamento exerceu efeitos significativos sobre as condições econômicas das regiões abrangidas pelo programa, e o governo federal parece ter sido responsabilizado pelas consequências decorrentes da sua instituição.

\subsection{Procedimentos metodológicos}

Conforme mencionado anteriormente, o objetivo deste estudo é analisar em que medida condições econômicas influenciam o desempenho eleitoral de candidatos incumbentes empregando uma estratégia empírica que explora instituição do programa de racionamento de energia elétrica ocorrido no Brasil entre 2001 e 2002. Também conforme mencionado anteriormente, há uma ampla literatura que analisa o efeito de condições econômicas sobre a decisão dos eleitores.

Para que a relação entre condições econômicas e desempenho eleitoral do incumbente seja identificada corretamente, qualquer fator não observável que influencie a escolha dos eleitores deve exibir correlação nula com as condições econômicas que, em maior ou menor grau, estão sob controle dos policymakers via instrumentos de política econômica. Esta hipótese de identificação pode não ser verdadeira, dado que as preferências dos eleitores muito provavelmente exercem efeito sobre o tipo de política econômica a ser posta em prática pelos governantes. De fato, vários estudos da literatura de Economia Política apresentam evidências de que algumas políticas parecem ser preferidas pelos eleitores, levando policymakers a naturalmente executá-las visando aumentar sua popularidade. Diferentemente dos estudos mencionados anteriormente neste capítulo, esta literatura não analisa o efeito de condições econômicas sobre o desempenho eleitoral, mas sim o efeito de diferentes políticas, em geral, fiscais. Esta literatura tem como uma de suas principais referências o trabalho de Rogoff (1990), segundo o qual manipulações fiscais em períodos próximos às eleições seriam uma forma do policymaker sinalizar "competência" ao seu eleitorado.

Segundo os resultados apresentados no tradicional estudo de Peltzman (1992), por exemplo, eleitores americanos são "conservadores", no sentido de que punem governantes que exercem políticas fiscais expansionistas provendo aos mesmos uma menor proporção de votos nas eleições. Ao analisar as eleições para o chefe do executivo municipal em Portugal, Veiga e Veiga (2007), por sua vez, encontram evidências de que partidos incumbentes são beneficiados pelos eleitores, via maior proporção de votos recebidos nas eleições locais, caso os mesmos ampliem os investimentos públicos durante o mandato. Também reforçando a relação entre política fiscal e desempenho eleitoral, Sakurai e Menezes-Filho (2008) encontram evidências de que eleitores brasileiros propiciam aos seus prefeitos maiores ou menores chances de reeleição a depender do tipo de gasto público por eles executados durante o mandato. De fato, o problema de endogeneidade entre instrumentos de política econômica e performance eleitoral dos incumbentes é explicitamente tratado por Aidt, Veiga e Veiga (2010), no qual os autores estimam um sistema de equações simultâneas visando analisar a relação entre manipulações fiscais em anos eleitorais e o sucesso eleitoral dos candidatos a prefeitos portugueses. Os resultados obtidos pelos autores indicam que manipulações fiscais são mais intensas quando as disputas eleitorais mais acirradas, e que são capazes de elevar a margem de vitória dos incumbentes.

br/folha/dinheiro/ult91u42646.shtml>. 
Considerando o raciocínio apresentado no parágrafo anterior, a identificação correta do efeito causal entre condições econômicas e escolha dos eleitores pode ser obtida caso seja possível explorar um evento exógeno que exerça efeito sobre as condições econômicas e que não tenha correlação com as preferências do eleitorado ou qualquer outro fator não observável que exerça influência sobre a decisão de voto dos eleitores. Como fonte de identificação, este estudo considera o fato de que os municípios dos estados da região Sul (em particular o estado do Paraná), não foram abrangidos pelo racionamento, ao passo que os municípios da região Sudeste (em particular o estado de São Paulo) foram abrangidos. Este conjunto de características permite usar a escassez de chuvas (e a instituição do racionamento) como um evento exógeno que potencialmente influenciou as condições econômicas e consequentemente, a decisão dos eleitores, por meio da combinação das metodologias Diff-in-Diff e IV. Segundo Costa e Gerard (2015), a instituição do racionamento se deu de forma não-antecipada pelos agentes, nem mesmo por consumidores industriais, atribuindo-lhe portanto um caráter "surpresa".

Existem algumas justificativas importantes para explorar apenas os municípios paulistas e paranaenses. Em primeiro lugar, conforme já mencionado neste estudo, muito embora alguns estados do Norte, Nordeste e Centro-Oeste também tenham feito parte do racionamento, havia significativas diferenças quanto à cobertura da distribuição de energia nos estados dessas regiões comparativamente aos estados das regiões Sul e Sudeste. Nos estados de São Paulo e Paraná, em particular, o nível de cobertura da distribuição era praticamente integral à época do racionamento (isto é, praticamente todos os usuários estavam conectados à rede), ao passo que em muitas regiões do Norte e Nordeste o grau de cobertura era significativamente menor e só se elevou ao longo dos anos mais recentes ${ }^{87}$. A inclusão de outros estados no grupo de tratamento violaria, portanto, o pressuposto de tendência comum pré-tratamento entre os grupos de tratamento e de controle, como é normalmente requerida em estimações do tipo Diff-in-Diff. Em segundo lugar, mesmo nos estados sujeitos ao racionamento as metas de redução de consumo e o prazo de duração do racionamento não foram iguais, o que traria heterogeneidade para o próprio grupo de tratamento. Em terceiro lugar, em função de sua posição geográfica, o estado de São Paulo seria um dos primeiros (provavelmente o primeiro) a ser beneficiado caso o sistema de distribuição de energia tivesse recebido investimentos de tal forma a receber energia gerada na região Sul. Por fim, dados em nível municipal de consumo de energia, por perfil de usuário e para um período temporal suficiente para a realização dos testes econométricos só puderam ser obtidos para esses dois estados.

Este estudo explora três conjuntos de informações. O primeiro conjunto contempla dados de consumo de energia elétrica (em megawatt por hora - MWh) e do número de unidades consumidoras, com frequência anual, por perfil de consumidor (residencial, comercial, industrial e rural) e por município. Essas informações foram obtidos junto à Fundação Sistema Estadual de Análise de Dados (SEADE), no caso dos municípios paulistas, e junto ao Instituto Paranaense de Desenvolvimento Econômico e Social (IPARDES), no caso dos municípios paranaenses. O segundo conjunto de dados, extraídos da Relação Anual de Informações Sociais (RAIS) e do Cadastro Geral de Empregados e Desempregados (CAGED) do Ministério do Trabalho, contempla informações referentes ao mercado

\footnotetext{
87 A partir de iniciativas como o programa "Luz para todos", por exemplo.
} 
de trabalho e que são utilizadas como medidas do efeito (consequência) do racionamento, também em nível municipal, em frequência anual. Para esses dois conjuntos de informações, foram considerados os anos entre 1995 e 2006. Por fim, os dados referentes ao desempenho dos candidatos à presidência da República nas eleições de 1998 e de 2002 (eleição imediatamente anterior e imediatamente posterior ao racionamento, respectivamente) foram obtidos junto ao TSE, e também estão em nível municipal. Em linha com os capítulos anteriores, as variáveis de controle são a população municipal ${ }^{88}$, a porcentagem de jovens e a taxa de urbanização.

A Equação 12 apresentada em sequência ${ }^{89}$ tem como objetivo estimar o efeito do racionamento sobre o consumo de energia elétrica e é bastante semelhante à especificação empregada por Costa e Gerard (2015). Muito embora esta equação não seja empregada diretamente nas estimações do desempenho eleitoral, seus resultados são importantes para ilustrar a magnitude do efeito causado pela instituição do racionamento. Esta equação é estimada separadamente para cada perfil de usuário, quais sejam, residencial, comercial e industrial ${ }^{90}$.

$$
\text { Consumo energia }_{i t}=\alpha+c_{i}+\psi \cdot d S P_{i}+\sum_{t=1}^{T} \theta_{t} . d A n o_{t}+\sum_{t=1}^{T} \rho_{t} . d S P_{i} . d A n o_{t}+\epsilon_{i t}
$$

A Equação 13, por sua vez, tem como objetivo estudar o comportamento dos indicadores de produção, emprego e renda a partir da instituição do racionamento ${ }^{91}$.

$$
\text { Condições econômicas } i t=\alpha+c_{i}+\psi \cdot d S P_{i}+\sum_{t=1}^{T} \theta_{t} \cdot d A n o_{t}+\sum_{t=1}^{T} \rho_{t} \cdot d S P_{i} \cdot d A n o_{t}+\epsilon_{i t}
$$

Esta equação também é estimada separadamente para cada indicador de atividade econômica obtido a partir da RAIS e do CAGED. Muito embora evidências anedóticas quanto aos efeitos da crise sobre a renda e o emprego já tenham sido mencionadas anteriormente neste trabalho, esta equação visa estimar formalmente seu efeito de tal forma que a escassez de chuvas possa ser vista como uma fonte exógena de variação das condições econômicas, isto é, a escassez de chuvas e a instituição do racionamento permitem estimar/identificar o eventual choque ocorrido sobre sobre esses indicadores. Esta equação pode ser vista, portanto, como o primeiro estágio da estratégia empírica adotada.

Para as Equações 12 e 13, $i$ define cada município da amostra, $t$ se refere aos anos de 1995 a 2006, dSP é uma variável binária que assume o valor 1 caso o município pertença ao estado de São Paulo (membro do grupo tratado, ou seja, sujeito ao racionamento) e 0 caso pertença ao estado do Paraná (membro do grupo de controle, ou seja, não sujeito ao

88 Em logaritmo natural.

89 Omite-se as variáveis de controle para facilitar a interpretação, muito embora as mesmas tenham sido incluídas nas estimações.

90 Esta equação não foi estimada para consumidores rurais, dado que representam uma proporção muito pequena do total consumido em cada município.

91 Novamente, omite-se as variáveis de controle, para facilitar a interpretação, muito embora as mesmas tenham sido incluídas nas estimações. 
racionamento), $d A n o_{t}$ são dummies de ano ${ }^{92}$ e $\epsilon$ se refere ao termo de erro. Os parâmetros de interesse nessas equações são os coeficientes $\rho$ dos anos de 2001 e 2002, que mensuram o efeito do racionamento sobre o consumo de energia e sobre o mercado de trabalho nos municípios paulistas nos anos em que houve racionamento, relativamente aos municípios paranaenses. Para facilitar a comparação, a dummy referente ao ano 2000 foi retirada das estimações por ser este o ano exatamente anterior à instituição do racionamento, tornando-a assim o ano de referência das dummies de ano. Procedimento semelhante é adotado por Moser, Voena e Waldinger (2014), por exemplo. Assim, coeficientes negativos e estatisticamente significantes para as interações dummy SP x dummy 2001 e dummy SP $\mathrm{x}$ dummy 2002 podem ser interpretados como efeitos negativos associados à instituição do racionamento.

Esta especificação, que envolve dummies de ano, pode ser vista como mais adequada para o problema aqui investigado pois permite capturar choques de curto prazo. Visando investigar a consistência destes resultados, são apresentados na Tabela C.1 do Apêndice $\mathrm{C}$ desta tese os resultados referentes a uma especificação Diff-in-Diff clássica, em que as proxies de atividade econômica são regredidas em função das variáveis $d S P$ (dummy de município paulista, ou seja, município do grupo de tratamento), d2001ow, que assume o valor 0 de 1995 até 2000 e o valor 1 de 2001 até 2006, e da interação entre ambas $d S P$ x d2001ow, além das variáveis de controle anteriormente mencionadas.

Por fim, a Equação 14, que representa o segundo estágio, tem como objetivo estudar a decisão de voto dos eleitores nas eleições presidenciais em função das condições econômicas definidas pela Equação 13 apresentada anteriormente ${ }^{93}$ :

$$
\text { Votos }_{i t}=\alpha+c_{i}+\psi \cdot d S P_{i}+\theta . d 2002+\varrho . \text { Condições econômicas } i t+\epsilon i t
$$

Em que $i$ novamente define cada município da amostra e $t$ se refere aos anos eleitorais de 1998 e 2002. Votos é definido como a proporção de votos recebida pelo candidato da situação à presidência da República (Fernando Henrique Cardoso em 1998 e José Serra em 2002). Ressalta-se que as estimações contemplam a proporção de votos recebida no primeiro turno de cada uma dessas duas eleições, dado que na eleição de 1998 o candidato incumbente venceu em primeiro turno e, portanto, não houve segundo turno. $d S P$ é definido como uma variável binária que assume o valor 1 se o município pertence ao estado de São Paulo e 0 se pertence ao estado do Paraná, d2002 é uma variável binária que assume o valor 1 no ano de 2002 e 0 no ano de 1998 e $\epsilon$ se refere ao erro. $\alpha$ representa a constante, $c_{i}$ representa o efeito fixo de cada município e $\psi, \theta$ e $\varrho$ representam os parâmetros a serem estimados. Note que o principal parâmetro é $\varrho$, que mensura o desempenho do candidato da situação à presidência em função das condições econômicas.

Note que em todas as equações, o procedimento Diff-in-Diff permite controlar pelo efeito específico $c_{i}$ de cada município para cada uma das variáveis dependentes. Nas Equações 12 e 13, dada a possibilidade de auto-correlação dos resíduos, o erro-padrão dos parâmetros é calculado realizando agrupamento (clustering) por município ${ }^{94}$. Por

\footnotetext{
92 Isto é, assumem o valor 1 no ano $t$ e 0 nos demais, e assim sucessivamente para cada ano $t$ da amostra.

93 Novamente, omite-se as variáveis de controle, para facilitar a interpretação.

94 Conforme sugerido por Bertrand, Duflo e Mullainathan (2004).
} 
sua vez, o erro-padrão dos coeficientes da Equação 14 foram obtidos via block bootstrap com 5.000 replicações, dado que esta inclui como regressor os indicadores de condições econômicas estimados por meio da Equação 13. A exemplo de Costa e Gerard (2015), não é realizado emparelhamento dos municípios paranaenses e paulistas via Propensity Score Matching, dado que fazer ou não fazer parte do racionamento (em última instância, fazer parte do estado de São Paulo ou do Paraná) não é uma decisão dos municípios e assim, pode ser tomada como exógena. Ademais, a designação dos municípios entre tratado ou controle não obedeceu a nenhuma característica específica dos municípios como porte populacional ou número de usuários, por exemplo. Por fim, conforme será apresentado na sequência deste trabalho, os municípios do grupo de tratamento e de controle exibem, para a maior parte das variáveis, tendência semelhante pré-tratamento, minimizando portanto a necessidade do emparelhamento.

Esta estratégia empírica, que envolve uma combinação de Diferenças-em-Diferenças e variáveis instrumentais, é inspirada no estudo de Waldinger (2010). Neste, o autor procura analisar o desempenho profissional dos doutores formados em Matemática por universidades alemãs em função da qualidade da instituição formadora. Dado o problema de viés de seletividade amostral (melhores alunos tendem a ingressar nas melhores universidades) e dada a influência de fatores não totalmente observáveis que afetam tanto a qualidade das universidades como a qualidade dos doutores formados, o autor explora variações exógenas da qualidade das instituições universitárias alemãs decorrentes da ascensão do partido nazista, que provocou a expulsão de professores judeus de diversas universidades da Alemanha, mas não de todas. Assim, em um primeiro estágio, o autor estima a produtividade dos docentes e a razão número de orientandos por docente ${ }^{95}$ em função da expulsão dos docentes judeus em uma equação do tipo Diferenças-em-Diferenças, em que as universidades alemãs que tiveram professores afastados formam o grupo de tratamento e as universidades que não tiveram professores afastados formam o grupo de controle. No segundo estágio, o autor analisa o efeito da qualidade da universidade sobre o desempenho dos doutores formados com base nos valores estimados no primeiro estágio ${ }^{96}$. Em nosso caso, o primeiro estágio equivale à estimação das condições econômicas em função da instituição do racionamento e o segundo estágio, por seu turno, equivale à estimação do desempenho eleitoral em função das condições econômicas estimadas no primeiro estágio. Cabe ressaltar que este procedimento também é inspirado no estudo de Franck (2016), já mencionado na revisão da literatura deste capítulo.

As Figuras 14(a), 14(b) e 14(c) apresentam, respectivamente, a evolução do consumo comercial, industrial e residencial de energia elétrica, mensurados em valores médios por unidade consumidora, entre 1995 e 2006. É possível observar redução do consumo para os três tipos de consumidor no ano de 2001 , da ordem de $15 \%, 11 \%$ e $18 \%$, respectivamente, em relação ao consumo registrado em 2000. Adicionalmente, o racionamento parece ter exercido efeitos de longo prazo sobre o consumo comercial e residencial, dado que os valores posteriores a 2001 parecem ser permanentemente mais baixos do que os registrados até então. As Figuras 15(a), 15(b) e 15(c) apresentam, por seu turno, a quantidade de usuários dos tipos comercial, industrial e residencial, respectivamente, ao passo que as Fi-

95 Que atuam como proxies para a qualidade da universidade.

$96 \mathrm{O}$ autor encontra resultados que sugerem que a qualidade da instituição formadora realmente exerce efeito positivo sobre o sucesso profissional dos doutores. 
Tabela 24 - Proporção de votos recebida pelo partido incumbente, por estado e eleição

\begin{tabular}{ccccc}
\hline Estado & Estatística & 1998 & 2002 & Diferença de médias \\
\hline \multirow{4}{*}{ Paraná } & Média & 59,03 & 31,94 & $-27,09^{* * *}$ \\
& Erro-padrão & 0,65 & 0,49 & \\
& Número de municípios & 399 & 399 & \\
\multirow{2}{*}{ São Paulo } & Média & 65,04 & 35,13 & $-29,91^{* * *}$ \\
& Erro-padrão & 0,37 & 0,36 & \\
& Número de municípios & 645 & 645 & \\
\hline & Diferença de médias & 6,01 & 3,19 & $-2,82^{* * *}$ \\
\hline
\end{tabular}

Fonte: elaboração própria

Notas: ${ }^{* * *}=$ Médias diferentes ao nível de significância estatística de $1 \%$;** $=$ Médias diferentes ao nível de significância estatística de $5 \%{ }^{*}=$ Médias diferentes ao nível de significância estatística de at $10 \%$

guras 16(a), 16(b) e 16(c) ilustram a evolução do número de horas semanais trabalhadas, número de meses (no mesmo) emprego e salário real mensal ${ }^{97}$, também respectivamente. Finalmente, as Figuras 17(a), 17(b) e 17(c) ilustram o comportamento da porcentagem da população municipal empregada formalmente nos setores comercial, industrial e de serviços, nesta ordem.

Muito embora seja possível constatar uma aparente queda do número de usuários do tipo industrial e uma queda dos salário mensal, nem todos os gráficos indicam mudanças bruscas no comportamento após 2001. Contudo, apenas um tratamento estatístico mais rigoroso permite quantificar o eventual efeito do racionamento sobre as condições de produção, renda e emprego ${ }^{98}$.

Ainda com vistas a apresentar uma visão preliminar do problema investigado neste capítulo, a Tabela 24 apresenta a média da proporção de votos recebidos pelo partido incumbente nas eleições presidenciais de 1998 e 2002, separadamente entre grupo de tratamento (municípios paulistas) e grupo de controle (municípios paranaenses). É possível notar que nas eleições de 2002, o candidato da situação apresentou desempenho mais fraco (comparativamente ao desempenho registrado em 1998) em ambos os estados, mas a redução dos votos recebidos parece ter sido mais proeminente justamente no estado de São Paulo. Entre as duas eleições, houve uma queda média de 27,09 pontos percentuais nos municípios paranaenses e uma queda média de aproximadamente 29,91 pontos percentuais nos municípios paulistas. A diferença entre esses dois valores, aproximadamente igual a 2,82 pontos percentuais, é estatisticamente significante a $1 \%$.

97 Visando controlar por efeitos sazonais e manter a mesma base de comparação, esta variável foi calculada da seguinte forma: dado que o racionamento vigorou entre junho de 2001 e fevereiro de 2002, calculou-se o salário mensal médio destes período, o qual foi associado ao ano de 2001. Para o ano de 2002, por sua vez, calculou-se o salário mensal médio entre junho de 2002 e fevereiro de 2003, e assim sucessivamente para todos os anos da amostra.

98 Conforme ilustrado por essas figuras, é possível notar que o grupo de tratamento e o grupo de controle apresentam tendências relativamente parecidas antes do tratamento, fortalecendo o argumento de não necessidade de emparelhamento via Propensity Score Matching. 


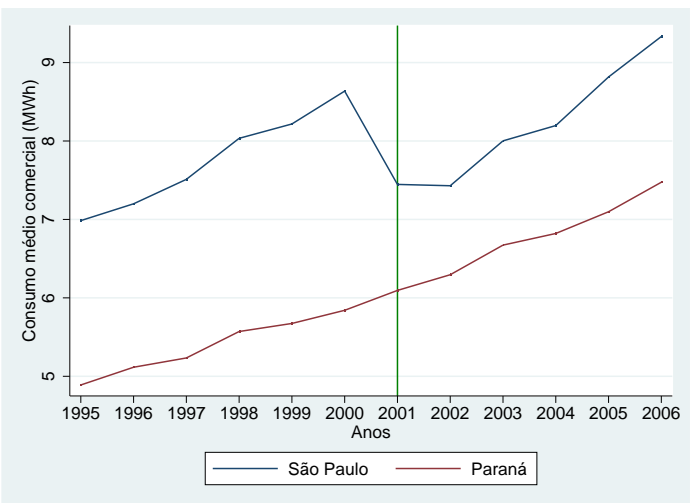

(a) Consumo médio de energia - comercial

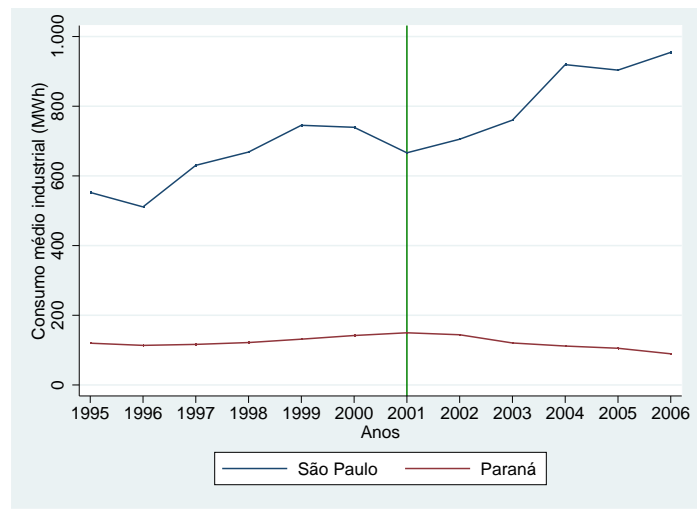

(b) Consumo médio de energia - industrial

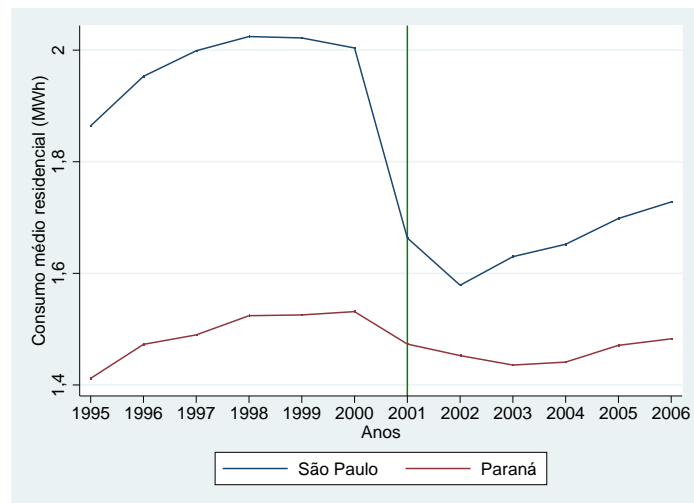

(c) Consumo de energia - residencial

Figura 14 - Consumo médio de energia, por tipo de usuário e ano

Fonte: elaboração própria

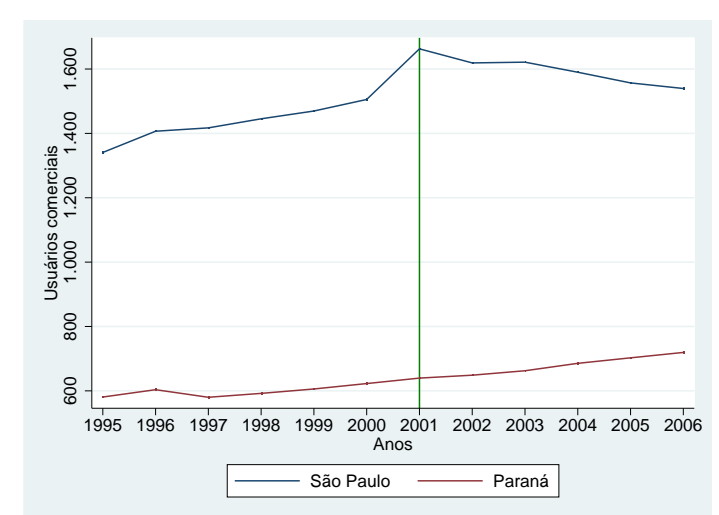

(a) Usuários comerciais

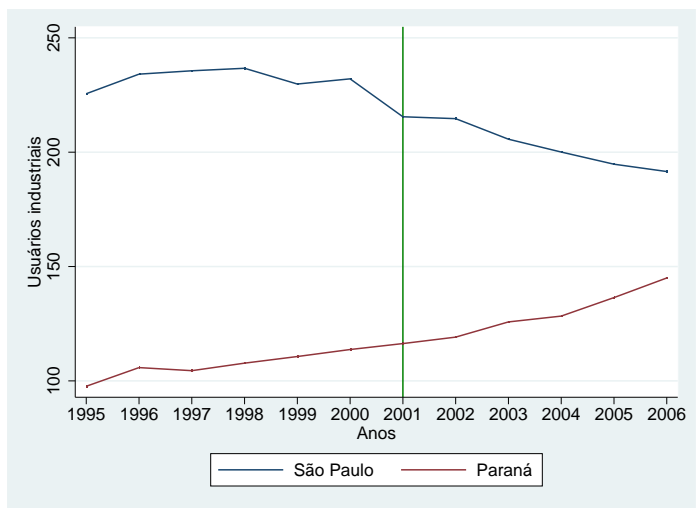

(b) Usuários industriais

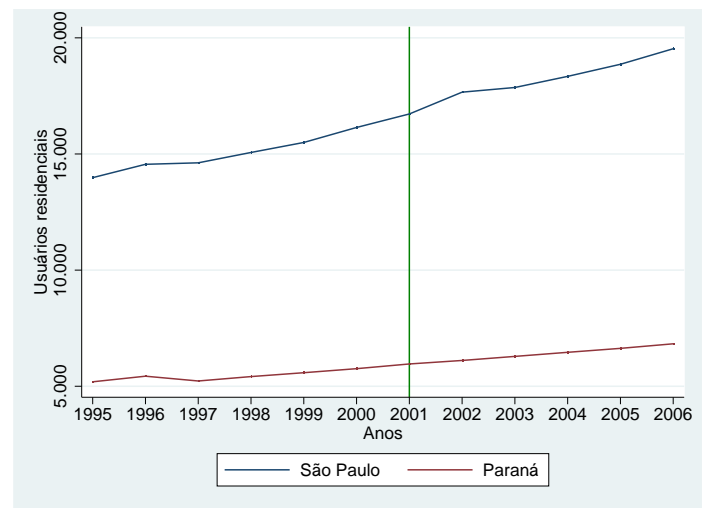

(c) Usuários residenciais

Figura 15 - Quantidade de usuários, por tipo de usuário e ano 


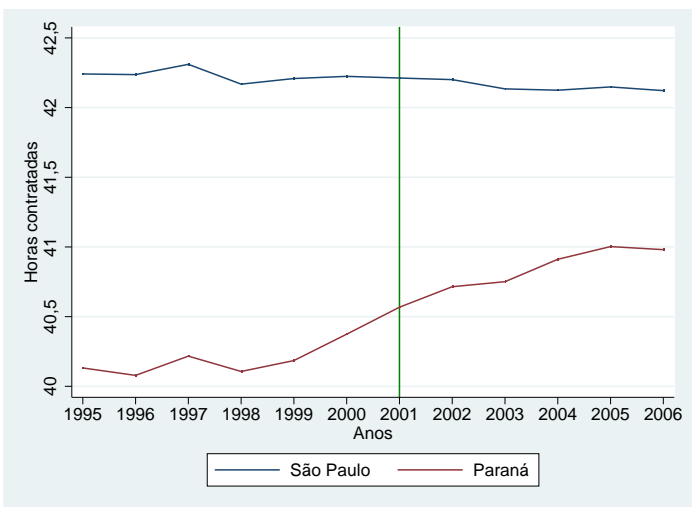

(a) Horas semanais contratadas

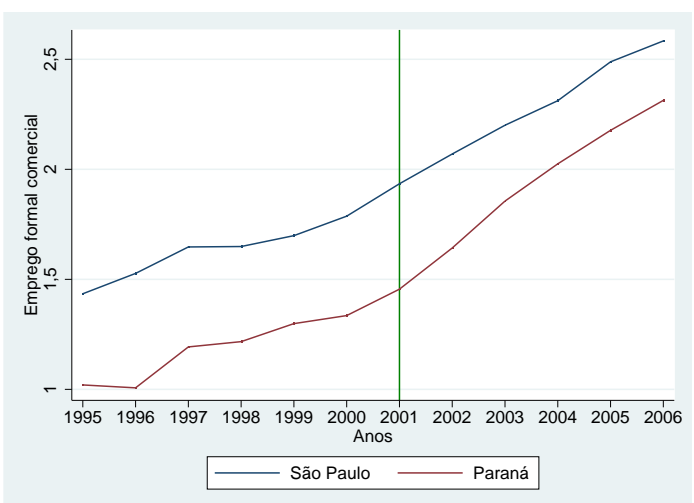

(a) Emprego formal comercial

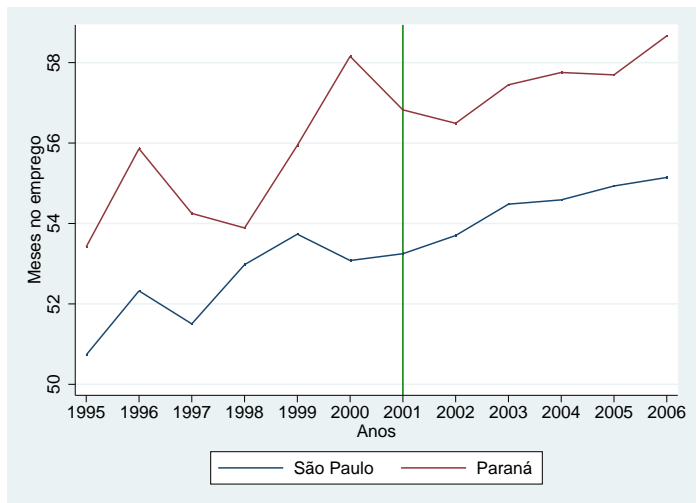

(b) Meses no emprego

Figura 16 - Indicadores econômicos

Fonte: elaboração própria

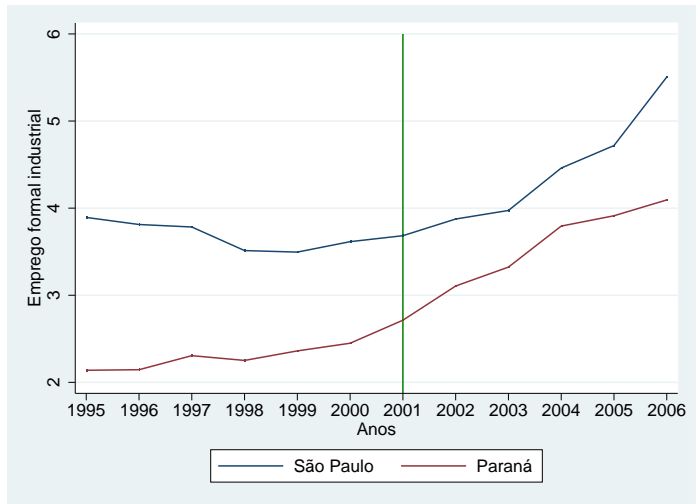

(b) Emprego formal industrial

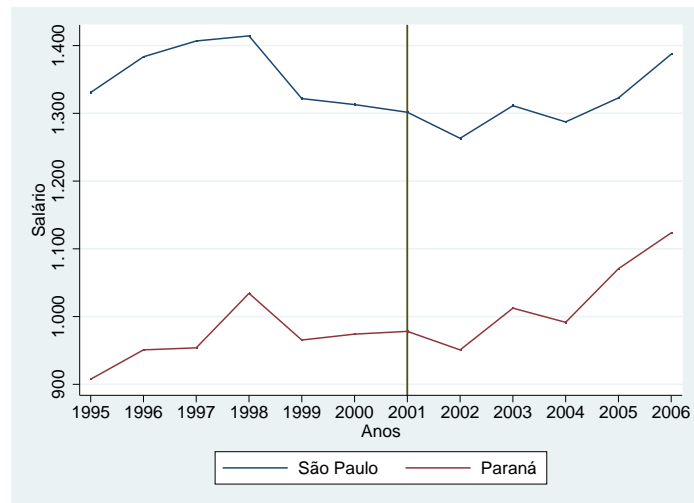

(c) Salário mensal

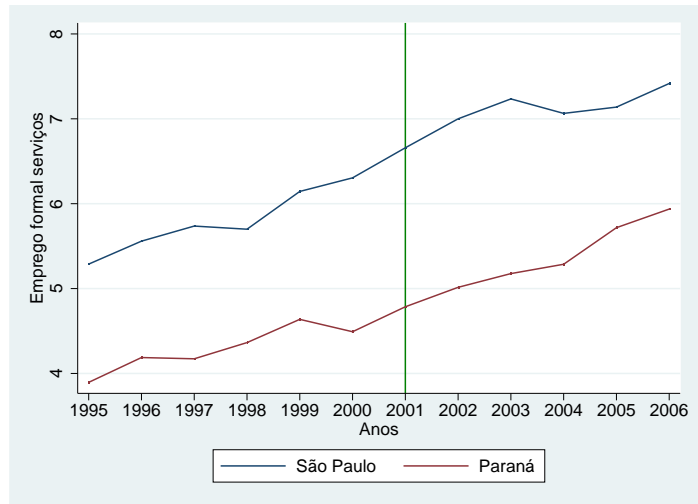

(c) Emprego formal serviços

Figura 17 - Indicadores econômicos (continuação)

Fonte: elaboração própria 


\subsection{Resultados}

Esta seção do capítulo apresenta os resultados das estimações das equações apresentadas na seção anterior. De forma análoga aos capítulos anteriores, asteriscos denotam significância estatística aos níveis de ${ }^{*}=10 \%,{ }^{* *}=5 \%$ e ${ }^{* * *}=1 \%$, respectivamente.

A Tabela 25 apresenta inicialmente os resultados referentes à forma reduzida da equação de desempenho eleitoral, na qual a proporção de votos é estimada em função das variáveis de controle, da dummy referente ao ano 2002 (período pós-tratamento) e da variável instrumental, definida pela interação entre a dummy de município paulista (grupo de tratamento) e a dummy do ano de $2002^{99,100}$. Os resultados da especificação apresentada na coluna A indicam que muito embora a proporção de votos recebida pelo partido incumbente na eleição de presidencial de 2002 tenha sido menor tanto nos municípios paranaenses como nos municípios paulistas (relativamente à eleição anterior, de 1998, esta queda foi de aproximadamente 27 pontos percentuais), esta redução foi ainda maior nos municípios paulistas dado que, nesses, a queda média adicional foi de aproximadamente 1,70 pontos percentuais. Note que este valor é relativamente menor do que o apresentado na Tabela 24, mas em termos qualitativos, o resultado sugerido é essencialmente o mesmo $^{101}$. Nas colunas B a E, por sua vez, são apresentados resultados que sugerem que a queda da proporção de votos nos municípios paulistas (em relação aos paranaenses) na eleição de 2002 (relativamente à eleição de 1998) foi maior nos municípios com maior população, com maior taxa de urbanização, com maior salário mensal médio e com maior proporção da população formalmente empregada ${ }^{102}$.

Os resultados referentes à Equação 12 são apresentados na Tabela 26, separadamente por tipo de usuário ${ }^{103}$. Os principais coeficientes, referentes à interação das dummies dos anos de 2001 e 2002 (anos do racionamento) com a dummy de município paulista (tratado), sugerem uma efetiva queda de consumo de energia elétrica em relação ao ano de 2000, pelos três tipos de consumidores do estado de São Paulo. No caso dos usuários industriais, o efeito parece ter sido predominantemente de curto prazo, dado que as interações são estatisticamente significativas apenas nos anos de 2001 e 2002 em si. Já

99 A dummy referente aos municípios paulistas é naturalmente omitida da regressão do tipo efeitos fixos, dado que é invariante no tempo.

${ }^{100}$ Em função da chamada restrição de exclusão, a forma reduzida do segundo estágio exclui a variável instrumental. Isto equivale a dizer que a variável instrumental (a escassez de chuvas e a instituição do racionamento) exerce efeito sobre a variável dependente de interesse (proporção de votos recebida pelo candidato) somente por meio do regressor endógeno, que no estudo aqui realizado são as condições econômicas. Trata-se esta de uma hipótese questionável dado que a instituição do racionamento pode ter exercido efeitos diretos sobre o desempenho eleitoral do incumbente. Ainda assim, os exercícios aqui apresentados podem ser considerados relevantes para a literatura de economic voting por trazerem novas evidências a partir do procedimento aqui empregado.

${ }^{101}$ Em sua forma reduzida do segundo estágio, Waldinger (2010) também encontra coeficientes negativos e estatisticamente significantes para sua variável instrumental, o que sugere efeitos negativos da expulsão de professores judeus sobre o desempenho dos doutores formados pelas universidades alemãs do grupo de tratamento.

${ }^{102}$ Para as regressões apresentadas nas colunas D e E, foram considerados o salário médio mensal e o emprego formal do ano de 2000, isto é, do ano imediatamente anterior à instituição do racionamento, dado que estas são endógenas ao próprio programa. Para as colunas B e C, foram considerados o tamanho da população e a taxa de urbanização do próprio ano de 2002 , dado que estas pouco provavelmente sofreram efeitos do racionamento.

${ }^{103}$ Com o consumo de energia mensurado em logaritmo natural para tornar os valores menos heterogêneos. 
Tabela 25 - Efeito das condições econômicas sobre o desempenho eleitoral - forma reduzida - efeitos fixos

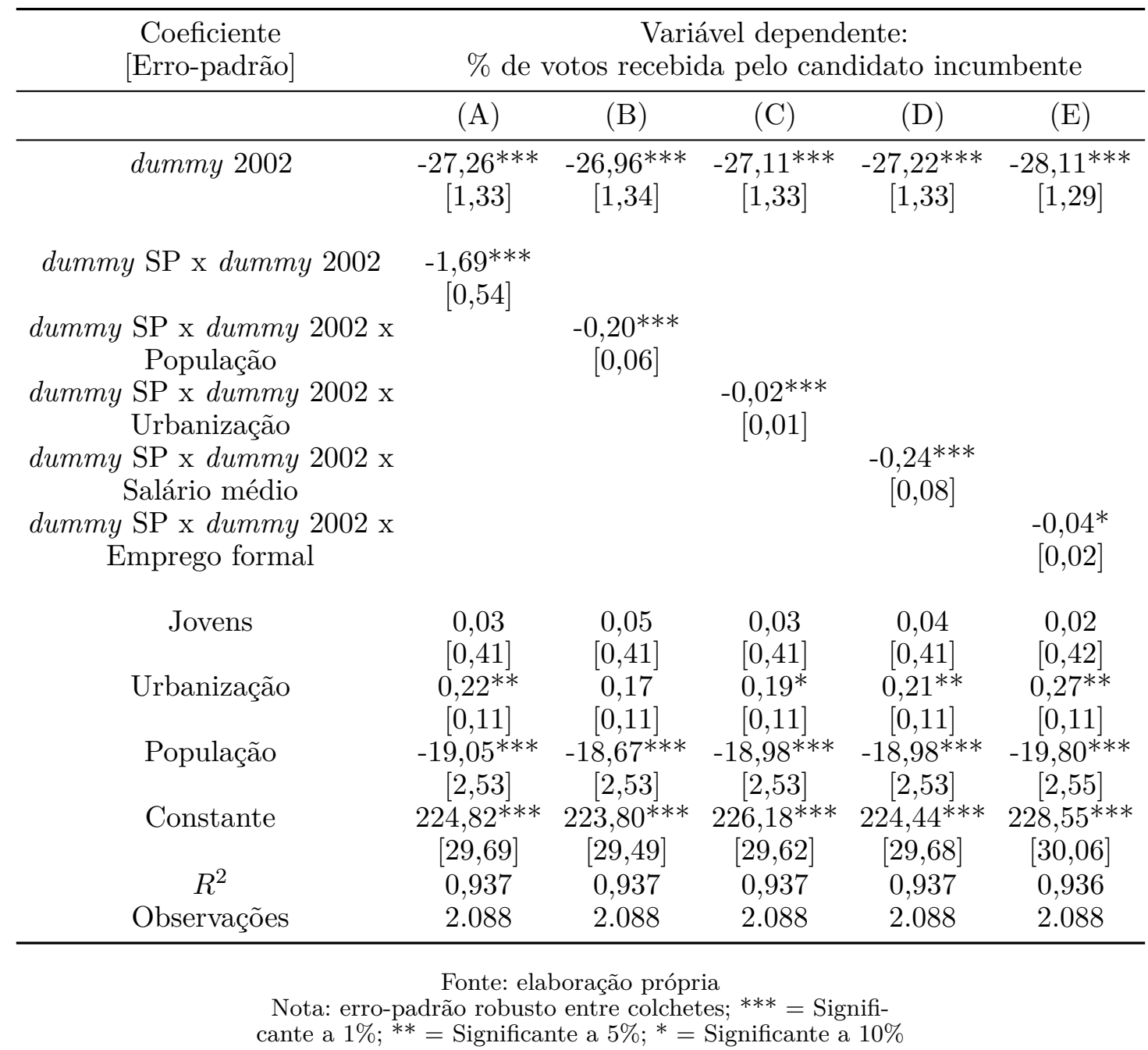

no caso dos usuários comerciais e residenciais, este efeito parece ter sido mais duradouro dado que todas as interações a partir do ano de 2001 (inclusive) são estatisticamente significantes até o ano de 2006, último ano da amostra. Estes resultados estão em linha com Bardelin (2004), segundo o qual os maiores responsáveis pela redução do consumo nos municípios do estado de São Paulo foram os setores residencial e comercial, seguidos em menor magnitude pelo setor industrial.

No caso dos consumidores residenciais, os resultados também indicam que mesmo nos municípios do estado Paraná houve redução de consumo de energia elétrica, resultado este bastante similar ao apresentado em Costa e Gerard (2015) e em linha com a discussão realizada por Bardelin (2004), e que pode ser explicado pela amplitude da campanha de conscientização de consumo de energia, que cobriu todos os estados do país, inclusive os da região Sul. Por fim, a redução de longo prazo observada no caso dos consumidores residenciais também está em linha com os resultados obtidos por Costa e Gerard (2015).

As Tabelas 27 e 28 apresentam os resultados referentes à Equação 13, que permite analisar os efeitos da instituição do racionamento sobre diferentes indicadores econômicos selecionados. A primeira dessas duas tabelas apresenta os resultados referentes às horas 
Tabela 26 - Efeito do programa de racionamento sobre o consumo de energia elétrica, por tipo de consumidor - Diferenças-em-Diferenças - efeitos fixos

\begin{tabular}{|c|c|c|c|}
\hline $\begin{array}{l}\text { Coeficiente } \\
{[\text { Erro-padrão] }}\end{array}$ & $\begin{array}{l}\text { Consumo } \\
\text { comercial }\end{array}$ & $\begin{array}{l}\text { Consumo } \\
\text { industrial }\end{array}$ & $\begin{array}{l}\text { Consumo } \\
\text { residencial }\end{array}$ \\
\hline dummy 1995 & $-0,19^{* * *}$ & $-0,06$ & $-0,08^{* * *}$ \\
\hline dummy 1996 & $\begin{array}{c}{[0,03]} \\
-0,14^{* * *} \\
{[0,02]}\end{array}$ & $\begin{array}{l}{[0,10]} \\
-0,07 \\
{[0,08]}\end{array}$ & $\begin{array}{c}{[0,01]} \\
-0,04^{* * *} \\
{[0,01]}\end{array}$ \\
\hline dummy 1997 & $\begin{array}{c}-0,12^{* * *} \\
{[0,02]}\end{array}$ & $\begin{array}{l}-0,09 \\
{[0,06]}\end{array}$ & $\begin{array}{c}-0,03 * * * \\
{[0,01]}\end{array}$ \\
\hline dummy 1998 & $\begin{array}{c}-0,06^{* * *} \\
{[0,01]}\end{array}$ & $\begin{array}{c}-0,08^{*} \\
{[0,04]}\end{array}$ & $\begin{array}{l}-0,01 \\
{[0,01]}\end{array}$ \\
\hline dummy 1999 & $\begin{array}{c}-0,04^{* * *} \\
{[0,01]}\end{array}$ & $\begin{array}{c}-0,07 * * * \\
{[0,03]}\end{array}$ & $\begin{array}{c}-0,01^{*} \\
{[0,01]}\end{array}$ \\
\hline dummy 2001 & $\begin{array}{c}0,04^{* * *} \\
{[0,01]}\end{array}$ & $\begin{array}{c}0,05^{* *} \\
{[0,02]}\end{array}$ & $\begin{array}{c}-0,04 * * * \\
{[0,01]}\end{array}$ \\
\hline dummy 2002 & $\begin{array}{c}0,07^{* * * *} \\
{[0,01]}\end{array}$ & $\begin{array}{c}0,04 \\
{[0,04]}\end{array}$ & $\begin{array}{c}-0,06^{* * *} \\
{[0,01]}\end{array}$ \\
\hline dummy 2003 & $\begin{array}{c}0,12^{* * *} \\
{[0,02]}\end{array}$ & $\begin{array}{c}0,02 \\
{[0,06]}\end{array}$ & $\begin{array}{c}-0,07^{* * *} \\
{[0,01]}\end{array}$ \\
\hline dummy 2004 & $\begin{array}{c}0,15^{* * *} \\
{[0,02]}\end{array}$ & $\begin{array}{c}0,07 \\
{[0,08]}\end{array}$ & $\begin{array}{c}-0,06^{* * *} \\
{[0,01]}\end{array}$ \\
\hline dummy 2005 & $\begin{array}{c}0,19^{* * *} \\
{[0,03]}\end{array}$ & $\begin{array}{c}0,04 \\
{[0,09]}\end{array}$ & $\begin{array}{c}-0,04^{* * *} \\
{[0,01]}\end{array}$ \\
\hline dummy 2006 & $\begin{array}{c}0,22^{* * *} \\
{[0,03]}\end{array}$ & $\begin{array}{c}0,03 \\
{[0,11]}\end{array}$ & $\begin{array}{c}-0,04 * * * \\
{[0,01]}\end{array}$ \\
\hline dummy SP x dummy 1995 & $\begin{array}{c}-0,07 * * * \\
{[0,01]}\end{array}$ & $\begin{array}{c}0,01 \\
{[0,06]}\end{array}$ & $\begin{array}{c}0,01 \\
{[0,01]}\end{array}$ \\
\hline dummy SP x dummy 1996 & $\begin{array}{c}-0,07 * * * \\
{[0,01]}\end{array}$ & $\begin{array}{c}0,01 \\
{[0,05]}\end{array}$ & $\begin{array}{c}0,01^{* *} \\
{[0,01]}\end{array}$ \\
\hline dummy SP x dummy 1997 & $\begin{array}{c}-0,04 * * * \\
{[0,01]}\end{array}$ & $\begin{array}{c}0,03 \\
{[0,04]}\end{array}$ & $\begin{array}{c}0,02^{* * *} \\
{[0,01]}\end{array}$ \\
\hline dummy SP x dummy 1998 & $\begin{array}{c}-0,03^{* * *} \\
{[0,01]}\end{array}$ & $\begin{array}{c}0,02 \\
{[0,04]}\end{array}$ & $\begin{array}{c}0,01^{* * *} \\
{[0,01]}\end{array}$ \\
\hline dummy SP x dummy 1999 & $\begin{array}{c}-0,01^{*} \\
{[0,01]}\end{array}$ & $\begin{array}{c}0,02 \\
{[0,03]}\end{array}$ & $\begin{array}{c}0,01^{* * * *} \\
{[0,01]}\end{array}$ \\
\hline dummy SP x dummy 2001 & $\begin{array}{c}-0,19^{* * *} \\
{[0,01]}\end{array}$ & $\begin{array}{c}-0,12^{* * *} \\
{[0,02]}\end{array}$ & $\begin{array}{c}-0,14^{* * *} \\
{[0,01]}\end{array}$ \\
\hline dummy SP x dummy 2002 & $\begin{array}{c}-0,21 * * * \\
{[0,01]}\end{array}$ & $\begin{array}{c}-0,10^{* * *} \\
{[0,03]}\end{array}$ & $\begin{array}{c}-0,18^{* * *} \\
{[0,01]}\end{array}$ \\
\hline dummy SP x dummy 2003 & $\begin{array}{c}-0,20 * * * \\
{[0,01]}\end{array}$ & $\begin{array}{l}-0,02 \\
{[0,04]}\end{array}$ & $\begin{array}{c}-0,14^{* * *} \\
{[0,01]}\end{array}$ \\
\hline dummy SP x dummy 2004 & $\begin{array}{c}-0,18^{* * *} \\
{[0,01]}\end{array}$ & $\begin{array}{l}-0,01 \\
{[0,05]}\end{array}$ & $\begin{array}{c}-0,12^{* * *} \\
{[0,01]}\end{array}$ \\
\hline dummy SP x dummy 2005 & $\begin{array}{c}-0,16 * * * \\
{[0,02]}\end{array}$ & $\begin{array}{c}0,04 \\
{[0,05]}\end{array}$ & $\begin{array}{c}-0,12^{* * *} \\
{[0,01]}\end{array}$ \\
\hline dummy SP x dummy 2006 & $\begin{array}{c}-0,14^{* * *} \\
{[0,02]}\end{array}$ & $\begin{array}{c}0,07 \\
{[0,06]}\end{array}$ & $\begin{array}{c}-0,11^{* * *} \\
{[0,01]}\end{array}$ \\
\hline Jovens & $\begin{array}{l}-0,01 \\
{[0,01]}\end{array}$ & $\begin{array}{l}-0,02 \\
{[0,02]}\end{array}$ & $\begin{array}{l}-0,01 \\
{[0,01]}\end{array}$ \\
\hline Urbanização & $\begin{array}{l}-0,01 \\
{[0,01]}\end{array}$ & $\begin{array}{c}0,01 \\
{[0,01]}\end{array}$ & $\begin{array}{c}0,01 \\
{[0,01]}\end{array}$ \\
\hline População & $\begin{array}{l}-0,04 \\
{[0,04]}\end{array}$ & $\begin{array}{c}0,13 \\
{[0,14]}\end{array}$ & $\begin{array}{c}-0,04^{* * *} \\
{[0,01]}\end{array}$ \\
\hline $\mathrm{N}^{\mathrm{O}}$ de usuários & $\begin{array}{l}-0,01 \\
{[0,01]}\end{array}$ & $\begin{array}{l}-0,01 \\
{[0,01]}\end{array}$ & $\begin{array}{l}-0,01 \\
{[0,01]}\end{array}$ \\
\hline Constante & $\begin{array}{c}2,36^{* * *} \\
{[0,47]}\end{array}$ & $\begin{array}{l}2,50 \\
{[1,73]}\end{array}$ & $\begin{array}{c}0,95^{* * * *} \\
{[0,14]}\end{array}$ \\
\hline Estatística F (p-valor) & $128,70(0,00)$ & $10,09(0,00)$ & $606,22(0,00)$ \\
\hline$R^{2}$ & 0,351 & 0,064 & 0,696 \\
\hline Observações & 12.419 & 12.417 & 12.425 \\
\hline
\end{tabular}

Fonte: elaboração própria

Nota: erro-padrão robusto entre colchetes; $* * *=$ Significante a $1 \% ; * *=$ Significante a $5 \% ;^{*}=$ Significante a $10 \%$. Consumo de energia mensurado em logaritmo natural. 
contratadas semanais, tempo no emprego (em meses), salário mensal médio ${ }^{104}$ e proporção da população formalmente empregada nos setores comercial e industrial, respectivamente. Já a segunda dessas tabelas apresenta os resultados referentes à porcentagem da população formalmente empregada no setor de serviços, número de usuários comerciais, número de usuários industriais e finalmente, número de usuários residenciais ${ }^{105}$. Conforme sugerido por Cameron e Trivedi (2005) e Wooldridge (2010), por exemplo, para cada uma dessas regressões, além das estatísticas t de cada parâmetro, são apresentadas as estatísticas $\mathrm{F}$ e seus respectivos p-valores referentes aos testes de significância conjunta dos regressores. Conforme pode ser visto, os resultados obtidos sugerem que os regressores são estatisticamente não nulos.

No caso das horas contratadas, os coeficientes associados às interações dummy SP x dummy 2001 e dummy SP x dummy 2002 são negativos e estatisticamente não nulos, sugerindo portanto um efeito negativo associado à instituição do racionamento relativamente ao ano de $2000^{106}$. Nota-se também que todas as interações posteriores ao ano de 2003 (inclusive) são negativas e estatisticamente significantes, o que parece sugerir um efeito de longo prazo a exemplo do ocorrido no caso do consumo de energia residencial. Resultado semelhante também é observado no caso do salário mensal médio e da quantidade de usuários industriais, para as quais todas as interações são negativas e estatisticamente significantes a partir do ano de 2001 (inclusive), isto é, esses indicadores parecem ter sido especialmente influenciados pelo programa de racionamento ${ }^{107}$. No caso do emprego industrial, por sua vez, os efeitos negativos do racionamento também são notados nos anos de 2001 e 2002, dado que as interações dummy SP x dummy 2001 e dummy SP x dummy 2002 são estatisticamente significantes ao nível estatístico de $10 \%{ }^{108}$. Para este indicador, note que o efeito negativo parece ter perdurado inclusive nos anos de 2003 e 2004.

Para as demais proxies de atividade econômica, as interações dummy SP x dummy 2001 e dummy SP x dummy 2002 não são estatisticamente significantes, sugerindo portanto efeito nulo do racionamento sobre as mesmas. No caso do tempo no emprego, as duas interações são positivas e estatisticamente significantes, sugerindo portanto uma elevação frente ao ano de 2000, e não uma redução. No caso do emprego no setor comercial, por seu turno, as interações são negativas e estatisticamente significantes somente a partir de 2003, o que não permite afirmar com maior segurança que este resultado se deva à instituição do programa. Já no caso do emprego no setor de serviços, todas as interações a partir de 2001 (inclusive) são estatisticamente nulas, o que sugere a ausência de mudanças bruscas a partir daquele ano. Por fim, o racionamento parece ter exercido efeito igualmente nulo sobre a quantidade de usuários comerciais e, em particular, sobre a quan-

\footnotetext{
${ }^{104}$ Em logaritmo natural, para minimizar a heterogeneidade dos valores.

${ }^{105}$ As três últimas dessas variáveis também estão mensuradas em logaritmo natural, para minimizar a heterogeneidade dos valores.

${ }^{106}$ Esses resultados são reforçados por testes estatísticos do tipo F, que sugerem que o coeficiente associado à interação dummy SP x dummy 2001 é estatisticamente significante ao nível de 4\%, e que o coeficiente associado à interação dummy SP x dummy 2002 é estatisticamente significante ao nível $1 \%$.

107 Testes estatísticos do tipo F sugerem que, no caso do salário mensal médio, as interações dummy SP x dummy 2001 e dummy SP x dummy 2002 são estatisticamente significantes ao nível de $2 \%$. Já no caso da quantidade de usuários industriais, estes mesmos coeficientes são estatisticamente significantes ao nível de $1 \%$.

${ }^{108}$ Esses resultados são reforçados por testes estatísticos do tipo F.
} 
tidade de usuários residenciais ${ }^{109}$. Conforme mencionado anteriormente, na Tabela C.1 do Apêndice $\mathrm{C}$ desta tese são apresentados resultados referentes à especificação Diff-in-Diff clássica, cujos resultados corroboram aqueles apresentados nas Tabelas 27 e 28.

Esses resultados sugerem que nem todos os indicadores econômicos registraram os efeitos negativos da instituição do racionamento. O setor produtivo da economia parece ter se ajustado via diminuição da carga horária de trabalho, com a consequente redução do salário médio, e via fechamento de empresas e de postos de trabalho no setor industrial. Já os impactos sobre os setores de comércio e de serviços parecem ter sido relativamente menores. Todas estas mudanças parecem ter ocorrido sem causar maior rotatividade dos trabalhadores, dado que o tempo médio no emprego parece não ter sofrido nenhum efeito relevante. Diante deste resultado, somente os indicadores cujos coeficientes sugerem efeitos negativos nos anos de 2001 e/ou 2002 serão considerados no segundo estágio ${ }^{110}$, cujos resultados são representados em sequência.

\footnotetext{
${ }^{109} \mathrm{O}$ que parece ser um resultado esperado dado que o racionamento pode ter, no máximo, diminuído o consumo dos usuários residenciais, mas sem diminuir o número de consumidores deste perfil.

${ }^{110}$ Nesses casos, pode-se dizer que o efeito do instrumento sobre a variável endógena é nulo, tornando-o inválido.
} 
Tabela 27 - Efeito do programa de racionamento sobre condições econômicas Diferenças-em-Diferenças - efeitos fixos

\begin{tabular}{|c|c|c|c|c|c|}
\hline $\begin{array}{c}\text { Coeficiente } \\
{[\text { Erro-padrão] }}\end{array}$ & $\begin{array}{c}\text { Horas } \\
\text { contratadas }\end{array}$ & $\begin{array}{l}\text { Tempo no } \\
\text { emprego }\end{array}$ & $\begin{array}{l}\text { Salário } \\
\text { médio }\end{array}$ & $\begin{array}{l}\text { Emprego } \\
\text { comércio }\end{array}$ & $\begin{array}{l}\text { Emprego } \\
\text { indústria }\end{array}$ \\
\hline \multirow[t]{2}{*}{ dummy 1995} & $-0,42^{* * *}$ & $-7,37 * * *$ & $-0,06 * * *$ & $-0,43^{* * *}$ & $-0,01$ \\
\hline & {$[0,16]$} & {$[1,28]$} & {$[0,02]$} & {$[0,08]$} & {$[0,61]$} \\
\hline \multirow[t]{2}{*}{ dummy 1996} & $-0,45 * * *$ & $-4,62 * * *$ & $-0,03^{*}$ & $-0,44^{* * *}$ & $-0,04$ \\
\hline & {$[0,14]$} & {$[1,08]$} & {$[0,02]$} & {$[0,07]$} & {$[0,49]$} \\
\hline \multirow[t]{2}{*}{ dummy 1997} & $-0,31^{* *}$ & $-6,11^{* * *}$ & $-0,02$ & $-0,24 * * *$ & 0,06 \\
\hline & {$[0,12]$} & {$[0,81]$} & {$[0,01]$} & {$[0,05]$} & {$[0,37]$} \\
\hline \multirow[t]{2}{*}{ dummy 1998} & $-0,31 * * *$ & $-4,85 * * *$ & $0,07 * * *$ & $-0,15^{* * *}$ & $-0,04$ \\
\hline & {$[0,10]$} & {$[0,65]$} & {$[0,01]$} & {$[0,04]$} & {$[0,24]$} \\
\hline \multirow[t]{2}{*}{ dummy 1999} & $-0,22^{* *}$ & $-2,60 * * *$ & $-0,01$ & $-0,04^{*}$ & $-0,05$ \\
\hline & {$[0,10]$} & {$[0,44]$} & {$[0,01]$} & {$[0,02]$} & {$[0,12]$} \\
\hline \multirow[t]{2}{*}{ dummy 2001} & $0,21 * *$ & $-1,12 * * *$ & 0,01 & $0,12^{* * *}$ & $0,23^{*}$ \\
\hline & {$[0,09]$} & {$[0,43]$} & {$[0,01]$} & {$[0,03]$} & {$[0,13]$} \\
\hline \multirow[t]{2}{*}{ dummy 2002} & $0,38 * * *$ & $-1,24^{* *}$ & $-0,02^{*}$ & $0,31 * * *$ & $0,58 * *$ \\
\hline & {$[0,11]$} & {$[0,62]$} & {$[0,01]$} & {$[0,04]$} & {$[0,26]$} \\
\hline \multirow[t]{2}{*}{ dummy 2003} & $0,44^{* * *}$ & $-0,08$ & $0,04^{* * *}$ & $0,53 * * *$ & $0,74^{* *}$ \\
\hline & {$[0,12]$} & {$[0,79]$} & {$[0,01]$} & {$[0,06]$} & {$[0,37]$} \\
\hline \multirow[t]{2}{*}{ dummy 2004} & $0,62 * * *$ & 0,41 & $0,02^{*}$ & $0,71 * * *$ & $1,18^{* *}$ \\
\hline & {$[0,14]$} & {$[0,95]$} & {$[0,01]$} & {$[0,06]$} & {$[0,49]$} \\
\hline \multirow{2}{*}{ dummy 2005} & $0,72 * * *$ & 0,54 & $0,10 * * *$ & $0,86^{* * *}$ & $1,24^{* *}$ \\
\hline & {$[0,16]$} & {$[1,13]$} & {$[0,01]$} & {$[0,08]$} & {$[0,60]$} \\
\hline \multirow[t]{2}{*}{ dummy 2006} & $0,72^{* * *}$ & 1,69 & $0,15^{* * *}$ & $1,00^{* * *}$ & $1,42^{* *}$ \\
\hline & {$[0,18]$} & {$[1,30]$} & {$[0,02]$} & {$[0,09]$} & {$[0,71]$} \\
\hline \multirow[t]{2}{*}{ dummy SP x dummy 1995} & $0,29 * *$ & $3,09 * * *$ & $0,07 * * *$ & 0,01 & $0,56 * * *$ \\
\hline & {$[0,13]$} & {$[0,83]$} & {$[0,01]$} & {$[0,05]$} & {$[0,17]$} \\
\hline \multirow[t]{2}{*}{ dummy SP x dummy 1996} & $0,34 * * *$ & $2,27 * * *$ & $0,07 * * *$ & $0,12^{* *}$ & $0,46^{* * *}$ \\
\hline & {$[0,12]$} & {$[0,83]$} & {$[0,01]$} & {$[0,06]$} & {$[0,16]$} \\
\hline \multirow[t]{2}{*}{ dummy SP x dummy 1997} & $0,29 * *$ & $3,20 * * *$ & $0,08 * * *$ & 0,05 & $0,26^{*}$ \\
\hline & {$[0,12]$} & {$[0,71]$} & {$[0,01]$} & {$[0,05]$} & {$[0,15]$} \\
\hline \multirow[t]{2}{*}{ dummy SP x dummy 1998} & $0,20 * *$ & $4,11^{* * *}$ & 0,01 & $-0,01$ & 0,03 \\
\hline & {$[0,10]$} & {$[0,62]$} & {$[0,01]$} & {$[0,04]$} & {$[0,12]$} \\
\hline \multirow[t]{2}{*}{ dummy SP x dummy 1999} & $0,17^{*}$ & $2,88^{* * *}$ & 0,01 & $-0,04$ & $-0,02$ \\
\hline & {$[0,10]$} & {$[0,49]$} & {$[0,01]$} & {$[0,03]$} & {$[0,06]$} \\
\hline \multirow[t]{2}{*}{ dummy SP x dummy 2001} & $-0,20 * *$ & $1,56 * * *$ & $-0,02^{* *}$ & 0,03 & $-0,14^{*}$ \\
\hline & {$[0,10]$} & {$[0,46]$} & {$[0,01]$} & {$[0,03]$} & {$[0,09]$} \\
\hline \multirow[t]{2}{*}{ dummy SP x dummy 2002} & $-0,35 * * *$ & $2,38 * * *$ & $-0,03^{* *}$ & $-0,02$ & $-0,38 * * *$ \\
\hline & {$[0,11]$} & {$[0,57]$} & {$[0,01]$} & {$[0,03]$} & {$[0,12]$} \\
\hline dummy SP x dummy 2003 & $-0,44^{* * *}$ & $2,25 * * *$ & $-0,05 * * *$ & $-0,11^{* *}$ & $-0,46 * * *$ \\
\hline & {$[0,11]$} & {$[0,69]$} & {$[0,01]$} & {$[0,05]$} & {$[0,16]$} \\
\hline dummy SP x dummy 2004 & $-0,60 * * *$ & $2,17 * * *$ & $-0,05 * * *$ & $-0,18 * * *$ & $-0,44^{* *}$ \\
\hline & {$[0,12]$} & {$[0,71]$} & {$[0,01]$} & {$[0,04]$} & {$[0,22]$} \\
\hline dummy SP x dummy 2005 & $-0,66^{* * *}$ & $2,63^{* * *}$ & $-0,09 * * *$ & $-0,15^{* * *}$ & $-0,26$ \\
\hline & {$[0,12]$} & {$[0,76]$} & {$[0,01]$} & {$[0,05]$} & {$[0,27]$} \\
\hline dummy SP x dummy 2006 & $-0,65^{* * *}$ & $1,94^{* *}$ & $-0,09 * * *$ & $-0,20 * * *$ & 0,01 \\
\hline & {$[0,13]$} & {$[0,82]$} & {$[0,01]$} & {$[0,06]$} & {$[0,35]$} \\
\hline Jovens & 0,04 & 0,28 & 0,01 & $-0,01$ & $-0,01$ \\
\hline & {$[0,03]$} & {$[0,28]$} & {$[0,01]$} & {$[0,02]$} & {$[0,16]$} \\
\hline Urbanização & 0,01 & $-0,03$ & $0,01 * * *$ & $-0,01^{* *}$ & $0,08 * * *$ \\
\hline & {$[0,01]$} & {$[0,08]$} & {$[0,01]$} & {$[0,01]$} & {$[0,02]$} \\
\hline População & $-0,43^{* *}$ & $-4,51 * * *$ & 0,02 & 0,04 & $-0,18$ \\
\hline & {$[0,21]$} & {$[1,73]$} & {$[0,02]$} & {$[0,13]$} & {$[0,54]$} \\
\hline Constante & $43,55^{* * *}$ & $89,70 * * *$ & $6,57^{* * *}$ & 2,34 & $-0,69$ \\
\hline & {$[2,66]$} & {$[20,38]$} & {$[0,27]$} & {$[1,49]$} & {$[8,58]$} \\
\hline Estatística F (p-valor) & $5,67(0,00)$ & $11,43(0,00)$ & $100,89(0,00)$ & $76,02(0,00)$ & $11,33(0,00)$ \\
\hline$R^{2}$ & 0,057 & 0,049 & 0,139 & 0,339 & 0,072 \\
\hline Observações & 12.384 & 12.384 & 12.384 & 12.316 & 11.993 \\
\hline
\end{tabular}

Fonte: elaboração própria

Nota: erro-padrão robusto entre colchetes; ${ }^{* * *}=$ Significante a $1 \% ; * *=$ Significante a $5 \%{ }^{*}=$ Significante a $10 \%$. Consumo de energia mensurado em logaritmo natural. 
Tabela 28 - Efeito do programa de racionamento sobre condições econômicas Diferenças-em-Diferenças - efeitos fixos (continuação)

\begin{tabular}{|c|c|c|c|c|}
\hline $\begin{array}{c}\text { Coeficiente } \\
{[\text { Erro-padrão] }}\end{array}$ & $\begin{array}{l}\text { Emprego } \\
\text { serviços }\end{array}$ & $\begin{array}{c}\mathrm{N}^{\circ} \text { usuários } \\
\text { comerciais }\end{array}$ & $\begin{array}{c}\mathrm{N}^{\circ} \text { usuários } \\
\text { industriais }\end{array}$ & $\begin{array}{l}\mathrm{N}^{\mathrm{o}} \text { usuários } \\
\text { residenciais }\end{array}$ \\
\hline dummy 1995 & $\begin{array}{c}-0,98^{* * *} \\
{[0,38]}\end{array}$ & $\begin{array}{c}-0,06^{* * *} \\
{[0,01]}\end{array}$ & $\begin{array}{c}-0,11^{* * *} \\
{[0,03]}\end{array}$ & $\begin{array}{c}-0,13^{* * *} \\
{[0,01]}\end{array}$ \\
\hline dummy 1996 & $\begin{array}{l}-0,61 \\
{[0,41]}\end{array}$ & $\begin{array}{c}-0,04^{* * *} * \\
{[0.01]}\end{array}$ & $\begin{array}{c}-0,08^{* * *} \\
{[0.03]}\end{array}$ & $\begin{array}{c}-0,08^{* * *} \\
{[0.01]}\end{array}$ \\
\hline dummy 1997 & $\begin{array}{c}-0,60 * * * \\
{[0,23]}\end{array}$ & $\begin{array}{c}-0,02^{* *} \\
{[0,01]}\end{array}$ & $\begin{array}{c}-0,06 * * * \\
{[0,02]}\end{array}$ & $\begin{array}{c}-0,07 * * * \\
{[0,01]}\end{array}$ \\
\hline dummy 1998 & $\begin{array}{c}-0,28^{*} \\
{[0,16]}\end{array}$ & $\begin{array}{c}-0,01^{*} \\
{[0,01]}\end{array}$ & $\begin{array}{l}-0,02 \\
{[0,02]}\end{array}$ & $\begin{array}{c}-0,04^{* * *} \\
{[0,01]}\end{array}$ \\
\hline dummy 1999 & $\begin{array}{c}0,04 \\
{[0,11]}\end{array}$ & $\begin{array}{c}0,01 \\
{[0,01]}\end{array}$ & $\begin{array}{l}-0,01 \\
{[0,01]}\end{array}$ & $\begin{array}{c}-0,01^{* * *} \\
{[0,01]}\end{array}$ \\
\hline dummy 2001 & $\begin{array}{c}0,34^{* * *} \\
{[0,13]}\end{array}$ & $\begin{array}{c}0,02^{* * *} * \\
{[0,01]}\end{array}$ & $\begin{array}{c}0,01 \\
{[0,01]}\end{array}$ & $\begin{array}{c}0,02^{* * *} * \\
{[0,01]}\end{array}$ \\
\hline dummy 2002 & $\begin{array}{c}0,62^{* * *} \\
{[0,18]}\end{array}$ & $\begin{array}{c}0,02^{* * *} \\
{[0,01]}\end{array}$ & $\begin{array}{c}0,04^{* *} \\
{[0,01]}\end{array}$ & $\begin{array}{c}0,05 * * * \\
{[0,01]}\end{array}$ \\
\hline dummy 2003 & $\begin{array}{c}0,83 * * * \\
{[0,23]}\end{array}$ & $\begin{array}{c}0,04 * * * \\
{[0,01]}\end{array}$ & $\begin{array}{c}0,09 * * * \\
{[0,02]}\end{array}$ & $\begin{array}{c}0,09 * * * \\
{[0,01]}\end{array}$ \\
\hline dummy 2004 & $\begin{array}{c}0,99 * * * \\
{[0,29]}\end{array}$ & $\begin{array}{c}0,07 * * * \\
{[0,01]}\end{array}$ & $\begin{array}{c}0,12^{* * *} \\
{[0,02]}\end{array}$ & $\begin{array}{c}0,13^{* * *} \\
{[0,01]}\end{array}$ \\
\hline dummy 2005 & $\begin{array}{c}1,46 * * * \\
{[0,35]}\end{array}$ & $\begin{array}{c}0,09 * * * \\
{[0,01]}\end{array}$ & $\begin{array}{c}0,18^{* * *} \\
{[0,03]}\end{array}$ & $\begin{array}{c}0,16^{* * *} \\
{[0,01]}\end{array}$ \\
\hline dummy 2006 & $\begin{array}{c}1,72^{* * *} \\
{[0,41]}\end{array}$ & $\begin{array}{c}0,11^{* * *} \\
{[0,02]}\end{array}$ & $\begin{array}{c}0,23 * * * \\
{[0,04]}\end{array}$ & $\begin{array}{c}0,20 * * * \\
{[0,01]}\end{array}$ \\
\hline dummy SP x dummy 1995 & $\begin{array}{c}-0,47^{*} \\
{[0,26]}\end{array}$ & $\begin{array}{c}-0,07 * * * \\
{[0,01]}\end{array}$ & $\begin{array}{l}0,04^{*} \\
{[0,02]}\end{array}$ & $\begin{array}{c}-0,04^{* * *} \\
{[0,01]}\end{array}$ \\
\hline dummy SP x dummy 1996 & $\begin{array}{l}-0,47 \\
{[0,38]}\end{array}$ & $\begin{array}{c}-0,05^{* * *} * \\
{[0,01]}\end{array}$ & $\begin{array}{c}0,03 \\
{[0,02]}\end{array}$ & $\begin{array}{c}-0,06^{* * *} \\
{[0,01]}\end{array}$ \\
\hline dummy SP x dummy 1997 & $\begin{array}{l}-0,23 \\
{[0,27]}\end{array}$ & $\begin{array}{c}-0,03 \text { *** } \\
{[0,01]}\end{array}$ & $\begin{array}{c}0,05^{* * * *} \\
{[0,02]}\end{array}$ & $\begin{array}{c}-0,03^{* * *} * \\
{[0,01]}\end{array}$ \\
\hline dummy SP x dummy 1998 & $\begin{array}{c}-0,50 * * \\
{[0,20]}\end{array}$ & $\begin{array}{c}-0,02^{* * * *} \\
{[0,01]}\end{array}$ & $\begin{array}{c}0,02 \\
{[0,02]}\end{array}$ & $\begin{array}{c}-0,02^{* * *} \\
{[0,01]}\end{array}$ \\
\hline dummy SP x dummy 1999 & $\begin{array}{c}-0,30^{* *} \\
{[0,13]}\end{array}$ & $\begin{array}{c}-0,01^{* * *} * \\
{[0,01]}\end{array}$ & $\begin{array}{c}0,01 \\
{[0,01]}\end{array}$ & $\begin{array}{c}-0,02^{* * *} \\
{[0,01]}\end{array}$ \\
\hline dummy SP x dummy 2001 & $\begin{array}{c}0,08 \\
{[0,14]}\end{array}$ & $\begin{array}{c}0,04^{* * *} \\
{[0,01]}\end{array}$ & $\begin{array}{c}-0,05^{* * *} \\
{[0,01]}\end{array}$ & $\begin{array}{c}0,02^{* * *} \\
{[0,01]}\end{array}$ \\
\hline dummy SP x dummy 2002 & $\begin{array}{c}0,21 \\
{[0,17]}\end{array}$ & $\begin{array}{c}0,04 * * * \\
{[0,01]}\end{array}$ & $\begin{array}{c}-0,09 * * * \\
{[0,01]}\end{array}$ & $\begin{array}{c}0,03 * * * \\
{[0,01]}\end{array}$ \\
\hline dummy SP x dummy 2003 & $\begin{array}{c}0,31 \\
{[0,21]}\end{array}$ & $\begin{array}{c}0,02^{* * *} \\
{[0,01]}\end{array}$ & $\begin{array}{c}-0,19^{* * *} * \\
{[0,02]}\end{array}$ & $\begin{array}{c}0,01 \\
{[0,01]}\end{array}$ \\
\hline dummy SP x dummy 2004 & $\begin{array}{c}0,07 \\
{[0,24]}\end{array}$ & $\begin{array}{l}-0,01 \\
{[0,01]}\end{array}$ & $\begin{array}{c}-0,22^{* * *} \\
{[0,02]}\end{array}$ & $\begin{array}{l}-0,01 \\
{[0,01]}\end{array}$ \\
\hline dummy SP x dummy 2005 & $\begin{array}{l}-0,26 \\
{[0,22]}\end{array}$ & $\begin{array}{c}-0,03^{* * *} * \\
{[0,01]}\end{array}$ & $\begin{array}{c}-0,31^{* * *} \\
{[0,02]}\end{array}$ & $\begin{array}{c}-0,02^{* * *} \\
{[0,01]}\end{array}$ \\
\hline dummy SP x dummy 2006 & $\begin{array}{l}-0,17 \\
{[0,24]}\end{array}$ & $\begin{array}{c}-0,05^{* * * *} \\
{[0,01]}\end{array}$ & $\begin{array}{c}-0,37^{* * * *} \\
{[0,02]}\end{array}$ & $\begin{array}{c}-0,04^{* * *} \\
{[0,01]}\end{array}$ \\
\hline Jovens & $\begin{array}{c}0,07 \\
{[0,09]}\end{array}$ & $\begin{array}{l}-0,01 \\
{[0,01]}\end{array}$ & $\begin{array}{l}-0,01 \\
{[0,01]}\end{array}$ & $\begin{array}{c}0,01 \\
{[0,01]}\end{array}$ \\
\hline Urbanização & $\begin{array}{l}-0,01 \\
{[0,04]}\end{array}$ & $\begin{array}{c}0,01 * * * \\
{[0,01]}\end{array}$ & $\begin{array}{c}0,01^{* *} \\
{[0,01]}\end{array}$ & $\begin{array}{c}0,01^{* * * *} \\
{[0,01]}\end{array}$ \\
\hline População & $\begin{array}{c}-1,66^{* *} \\
{[0,65]}\end{array}$ & $\begin{array}{c}0,43^{* * *} \\
{[0,04]}\end{array}$ & $\begin{array}{c}0,30 * * * \\
{[0,06]}\end{array}$ & $\begin{array}{c}0,41 * * * \\
{[0,04]}\end{array}$ \\
\hline Constante & $\begin{array}{c}18,95^{* *} \\
{[8,52]}\end{array}$ & $\begin{array}{c}1,15^{* *} \\
{[0,47]}\end{array}$ & $\begin{array}{c}0,70 \\
{[0,68]}\end{array}$ & $\begin{array}{c}3,65^{* * *} \\
{[0,43]}\end{array}$ \\
\hline Estatística F (p-valor) & $25,93(0,00)$ & $128,28(0,00)$ & $29,44(0,00)$ & $337,93(0,00)$ \\
\hline$R^{2}$ & 0,047 & 0,540 & 0,167 & 0,760 \\
\hline Observações & 12.380 & 12.420 & 12.421 & 12.425 \\
\hline
\end{tabular}

Fonte: elaboração própria

Nota: erro-padrão robusto entre colchetes; ${ }^{* *}=$ Significante a $1 \%$; $* *=$ Significante a $5 \%{ }^{*}=$ Significante a $10 \%$. Consumo de energia mensurado em logaritmo natural. 
A Tabela 29 apresenta os resultados referentes à Equação 14, que estima os efeitos das condições econômicas (estimadas no primeiro estágio) sobre a performance eleitoral, tanto via OLS como via Variáveis Instrumentais. Com o objetivo de testar a consistência dos resultados, além de quatro diferentes medidas de atividade econômica, são estimadas três especificações alternativas, explicadas a seguir.

No Painel A, são apresentados os resultados em que a proporção de votos é regredida em função dos valores contemporâneos das condições econômicas, isto é, os valores das proxies de condições econômicas do ano de 1998 são os regressores do desempenho eleitoral de 1998 e as condições econômicas do ano de 2002, por sua vez, são os regressores do desempenho eleitoral de 2002. Esta especificação permite investigar, portanto, como a performance eleitoral dos incumbentes é influenciada especificamente pelas condições econômicas vigentes no ano eleitoral em si.

No Painel B são apresentados os resultados de uma especificação alternativa que procura levar em conta o fato de que o racionamento influenciou (negativamente) as condições econômicas não só do ano de 2002, mas também no ano de 2001. Assim, nesta especificação, a média das condições econômicas de 1997 e 1998 são os regressores do desempenho eleitoral de 1998 e a média das condições econômicas de 2001 e 2002 são os regressores do desempenho eleitoral de 2002. Posto de outra forma, esta segunda especificação permite verificar como as condições econômicas dos dois últimos anos do mandato (e não só as condições do ano eleitoral em si) influenciam o desempenho de candidatos incumbentes nas eleições.

Por fim, no Painel C, são apresentados os resultados de uma terceira especificação inspirada nos trabalhos de Sakurai e Menezes-Filho (2008), Aidt, Veiga e Veiga (2010) e Elinder (2010), entre outros, que argumentam que eleitores são especialmente sensíveis às mudanças que ocorrem às vésperas das eleições. Procurando também levar em conta a motivação da especificação apresentada no Painel B, para cada indicador econômico, calcula-se a variação proporcional entre a média dos anos de 1995 e 1996 (dois primeiros anos do mandato 1995-1998) a a média dos anos de 1997 e 1998 (dois últimos anos do mandato 1995-1998) e utiliza-se esta como variável explicativa do desempenho eleitoral em 1998, e para o desempenho eleitoral da eleição de 2002, considera-se como regressor a variação proporcional entre a média das condições econômicas dos anos de 1999 e 2000 (dois primeiros anos do mandato 1999-2002) e a média dos anos de 2001 e 2002 (dois últimos anos do referido mandato). Assim, esta especificação permite analisar como eleitores respondem à mudanças das condições econômicas observadas em períodos próximos às eleições.

No caso da especificação referente ao Painel A, as condições econômicas esperadas são obtidas exatamente a partir das regressões apresentadas nas Tabelas 27 e 28, mas no caso das especificações apresentadas no Painel B e C, foi naturalmente necessário recalcular as condições econômicas e regredi-las novamente de tal forma a obter os valores esperados, para só então inclú́-las como regressores do segundo estágio. Os resultados destas estimações são apresentadas nas Tabelas C.2 e C.3 do Apêndice C desta tese. Ressalta-se que a variável dependente das regressões apresentadas na Tabela 29 é sempre a proporção de votos recebida pelo partido incumbente no primeiro turno das eleições presidenciais de 1998 e 2002, variando entre as colunas o indicador econômico utilizado 
como variável explicativa e o método de estimação (IV ou OLS). Partindo-se do pressuposto de que melhores condições econômicas são realmente convertidas pelos eleitores em uma maior proporção de votos recebida pelos incumbentes, e dado o perfil dos quatro indicadores de condição econômica utilizados neste segundo estágio, espera-se coeficientes positivos e estatisticamente significantes para os mesmos.

Conforme pode ser visto na Tabela 29, os resultados obtidos sugerem que melhores condições econômicas efetivamente aumentam o sucesso eleitoral dos candidatos incumbentes. Qualquer que seja a especificação considerada (Painel A, B ou C), os parâmetros referentes às quatro proxies de condições econômicas obtidos via método de variáveis instrumentais são positivos e estatisticamente significantes ao nível máximo de $10 \%$.

Tomando como exemplo o efeito das horas contratadas do próprio ano eleitoral (Painel A), um aumento marginal de uma hora semanal eleva a proporção de votos em aproximadamente 3 pontos percentuais. Magnitude bastante semelhante é observada no caso do Painel B, o que sugere que melhores condições econômicas nos dois últimos anos do mandato também exercem efeitos positivos sobre o desempenho eleitoral de incumbentes. Já no caso da taxa de variação (entre a média do primeiro e a média do segundo biênio do mandato) das horas contratadas (Painel C), um aumento de 1 ponto percentual eleva a proporção recebida de votos em aproximadamente 2,6 pontos percentuais. Ainda em relação à especificação apresentada no Painel C, um crescimento de 1 ponto percentual na taxa de variação ${ }^{111}$ do salário real aumenta a proporção recebida de votos em aproximadamente 1 ponto percentual.

O mais interessante a ser notado, contudo, é o fato de que os resultados obtidos via Variáveis Instrumentais são significativamente diferentes daqueles obtidos via OLS: muitos dos resultados gerados por meio deste último método sugerem um efeito estatisticamente nulo das condições econômicas sobre o desempenho eleitoral e em alguns casos, os coeficientes chegam a ser inclusive negativos. Assim, estes resultados levariam à conclusões equivocadas quanto ao efeito de condições econômicas sobre o sucesso eleitoral de candidatos da situação pois ou sinalizariam que ou este efeito não é existente ou então, que um melhor desempenho eleitoral estaria associado à piores indicadores de atividade econômica. Desta forma, esses resultados parecem reforçar presença de uma possível endogeneidade entre condições econômicas e desempenho eleitoral no caso brasileiro, dando suporte ao procedimento empírico empregado neste estudo.

Os resultados anteriormente apresentados, que sugerem um efeito positivo de melhores condições econômicas sobre o desempenho eleitoral de candidatos incumbentes, podem ser questionados em função da real efetividade desta relação. Dada a natureza da variável instrumental aqui empregada e dado que seu efeito negativo sobre as condições econômicas pode ter sido mais severo ou, no limite, observado somente em localidades de maior porte ${ }^{112}$, os resultados obtidos podem estar sendo influenciados pela presença de municípios de grande porte na amostra.

Para discutir esta possibilidade, a Tabela 30 apresenta resultados referentes às mesmas especificações apresentadas na Tabela 29 separadamente para dois grupos especí-

\footnotetext{
${ }_{111}$ Entre a média do primeiro e a média do segundo biênio do mandato.

${ }^{112}$ Poder-se-ia argumentar, por exemplo, que o efeito das condições econômicas sobre o voto é mais forte em localidades mais populosas, mais urbanizadas e com maior presença do setor industrial.
} 
ficos de municípios, considerados de menor porte: o primeiro, composto por aqueles com população abaixo de 10 mil habitantes (Painéis A, B e C) e o segundo, composto por municípios com população entre 10 mil e 50 mil habitantes (Painéis D, E e F) ${ }^{113}$. Para facilitar a exposição dos resultados, são apresentados apenas os parâmetros referentes às diferentes medidas de atividade econômica, sendo omitidos os parâmetros referentes às demais variáveis explicativas.

Os resultados referentes a este exercício corroboram os anteriormente apresentados, ou seja, mesmo em municipalidades de menor porte, continuam indicando que melhores condições exercem de fato efeito positivo sobre o sucesso eleitoral de candidatos incumbentes, dado que os coeficientes continuam sendo todos positivos e estatisticamente significantes ao nível estatístico máximo de 10\%. Ademais, a diferença significativa entre os coeficientes obtidos via OLS e IV continua sinalizando um possível viés de endogeneidade nesta relação, endogeneidade esta que pode ter sido neglicenciada pela literatura até então existente. Note que a maior parte dos coeficientes obtidos via OLS continua sendo ou positiva mas estatisticamente não significante ou até mesmo negativa.

\subsection{Considerações finais do capítulo}

Em que medida o desempenho eleitoral de candidatos incumbentes é influenciado por condições econômicas? Muito embora esta seja uma questão já amplamente investigada pela literatura, este capítulo teve como objetivo abordar esta questão colocando em prática uma combinação dos métodos de Diferenças-em-Diferenças e Variáveis Instrumentais baseada no estudo realizado por Waldinger (2010), em que foram exploradas variações exógenas das condições econômicas decorrentes da instituição do programa de racionamento de energia elétrica no Brasil. Em particular, este estudo explorou o fato de que o referido programa, instituído entre junho de 2001 e fevereiro de 2002, não foi instituído em todas as regiões do país. Assim, os municípios paulistas, submetidos ao programa, formaram o grupo de tratamento ao passo que os municípios paranaenses, não submetidos ao referido programa, formaram o grupo de controle.

No primeiro estágio, foram apresentadas evidências de que o racionamento gerou consequências efetivamente negativas sobre alguns dos indicadores econômicos dos municípios do grupo de tratamento relativamente às localidades do grupo de controle. Contudo, nem todos apresentaram evidências robustas de efeitos negativos, como no caso do tempo no (número de meses no mesmo) emprego e do emprego nos setores de comércio e de serviços, por exemplo. No segundo estágio, por sua vez, foram encontrados resultados que corroboram a percepção de que melhores condições são convertidas pelos eleitores em uma maior proporção de votos recebida pelo partido incumbente nas eleições presidenciais de 1998 e de 2002. Este resultado é válido inclusive em municipalidades de menor porte, em que setores como a indústria e o comércio são em geral menos relevantes e o setor público, por outro lado, mais presente, comparativamente à localidades de maior porte.

Os resultados obtidos neste estudo trazem novas contribuições à literatura de economic voting por sugerir que o efeito das condições econômicas sobre a performance

\footnotetext{
113 A definição dessas faixas populacionais foi feita com base na população do ano de 2000 como referência, dado que este é o ano imediatamente anterior à instituição do racionamento.
} 
eleitoral dos incumbentes pode ter sido subestimado pelos estudos realizados até então. Muito embora a aplicação destes resultados ou mesmo a possibilidade de endogeneidade para outros países deva ser vista com cautela, os resultados das estimações realizadas por meio do método aqui empregado sugerem um efeito positivo e estatisticamente significante das condições econômicas sobre o desempenho eleitoral de incumbentes. Estes resultados são significativamente diferentes dos resultados obtidos via OLS (sujeitas ao viés de endogeneidade, portanto), que sugerem resultados significativamente distintos. Para algumas especificações e para algumas das proxies de atividade econômica aqui analisadas, os resultados são estatisticamente não significantes e em alguns casos, chegam a ser até mesmo negativos, o que vai de encontro à boa parte dos resultados obtidos pela literatura até então. Conforme discutido na revisão da literatura deste capítulo, também há alguns estudos encontram resultados que sugerem uma fraca associação entre condições econômicas e desempenho eleitoral, mas se esses estudos estão sujeitos ao possível viés de endogeneidade aqui discutido, então, seus resultados devem ser vistos com cautela, pois estão sujeitos a não endereçar adequadamente o problema proposto. Assim, muito embora marginalmente, entende-se que este estudo pôde contribuir com a literatura ao trazer novas evidências sobre como eleitores são influenciados pelas condições econômicas ao realizar a escolha de seus governantes. 
Tabela 29 - Efeito das condições econômicas sobre a performance eleitoral - Variável instrumental e OLS - efeitos fixos

\begin{tabular}{|c|c|c|c|c|c|c|c|c|}
\hline \multirow[t]{2}{*}{$\begin{array}{c}\text { Coeficiente } \\
{[\text { Erro-padrão] }}\end{array}$} & \multicolumn{2}{|c|}{$\begin{array}{c}\text { Horas } \\
\text { contratadas }\end{array}$} & \multicolumn{2}{|c|}{$\begin{array}{l}\text { Salário } \\
\text { médio }\end{array}$} & \multicolumn{2}{|c|}{$\begin{array}{l}\text { Emprego } \\
\text { indústria }\end{array}$} & \multicolumn{2}{|c|}{$\begin{array}{l}\mathrm{N}^{\mathrm{o}} \text { usuários } \\
\text { industriais }\end{array}$} \\
\hline & IV & OLS & IV & OLS & IV & OLS & IV & OLS \\
\hline \multicolumn{9}{|c|}{ Painel A: Indicador econômico do ano eleitoral } \\
\hline dummy 2002 & $-29,40 * * *$ & $-28,69 * * *$ & $-25,09^{* * *}$ & $-28,93^{* * *}$ & $-29,83^{* * *}$ & $-28,60 * * *$ & $-28,14^{* * *}$ & $-28,63^{* * *}$ \\
\hline \multirow{2}{*}{ Condição econômica } & $3,09^{* * *}$ & $\begin{array}{c}{[1,25]} \\
0,12\end{array}$ & $39,79 * * *$ & $\begin{array}{l}{[1,2 b]} \\
-3,51^{*}\end{array}$ & $\begin{array}{c}{[1,32]} \\
3,88 * * *\end{array}$ & $\begin{array}{l}{[1,20]} \\
-0.13\end{array}$ & $\begin{array}{c}{[1,26]} \\
15,49 * * *\end{array}$ & $\begin{array}{c}{[1,24]} \\
1,14\end{array}$ \\
\hline & {$[0,99]$} & {$[0,17]$} & {$[13,11]$} & {$[1,83]$} & {$[1,33]$} & {$[0,09]$} & {$[5,06]$} & {$[0,83]$} \\
\hline \multirow[t]{2}{*}{ Jovens } & $-0,08$ & $-0,04$ & 0,14 & $-0,04$ & 0,07 & 0,02 & 0,10 & $-0,02$ \\
\hline & {$[0,41]$} & {$[0,41]$} & {$[0,41]$} & {$[0,42]$} & {$[0,42]$} & {$[0,42]$} & {$[0,42]$} & {$[0,41]$} \\
\hline \multirow[t]{2}{*}{ Urbanização } & $0,19^{*}$ & $0,30 * * *$ & 0,12 & $0,32 * * *$ & $-0,02$ & $0,36 * * *$ & 0,14 & $0,30 * * *$ \\
\hline & {$[0,11]$} & {$[0,11]$} & {$[0,12]$} & {$[0,11]$} & {$[0,17]$} & {$[0,11]$} & {$[0,12]$} & {$[0,11]$} \\
\hline \multirow[t]{2}{*}{ População } & $-17,71^{* * * *}$ & $-20,38^{* * *}$ & $-19,90^{* * *}$ & $-20,77^{* * *}$ & $-18,92^{* * *}$ & $-21,37^{* * *}$ & $-23,69 * * *$ & $-20,73^{* * * *}$ \\
\hline & {$[2,66]$} & {$[2,53]$} & {$[2,51]$} & {$[2,48]$} & {$[2,57]$} & & {$[2,79]$} & {$[2,50]$} \\
\hline \multirow[t]{2}{*}{ Constante } & $90,74^{*}$ & $229,27^{* * *}$ & $-49,02$ & $261,40^{* * * *}$ & $228,52^{* * *}$ & $237,90 * * *$ & $214,51^{* * *} *$ & $232,49 * * *$ \\
\hline & {$[54,58]$} & {$[31,25]$} & {$[97,73]$} & {$[32,03]$} & {$[29,97]$} & {$[29,11]$} & {$[31,24]$} & {$[30,09]$} \\
\hline$R^{2}$ & 0,937 & 0,936 & 0,937 & 0,936 & 0,939 & 0,939 & 0,937 & 0,936 \\
\hline Observações & 2.088 & 2.088 & 2.088 & 2.088 & 2.088 & 2.088 & 2.088 & 2.088 \\
\hline \multicolumn{9}{|c|}{ Painel B: Indicador econômico da média dos dois últimos anos do mandato } \\
\hline \multirow[t]{2}{*}{ dummy 2002} & $-29,62^{* * *}$ & $-28,99 * * *$ & $-27,52^{* * *}$ & $-29,15^{* * *}$ & $-29,19 * * *$ & $-28,78 * * *$ & $-28,19 * * *$ & $-28,62^{* * *}$ \\
\hline & {$[1,29]$} & {$[1,25]$} & {$[1,37]$} & {$[1,28]$} & {$[1,27]$} & {$[1,26]$} & {$[1,25]$} & {$[1,25]$} \\
\hline \multirow[t]{2}{*}{ Condição econômica } & $3,07^{* * *}$ & 0,22 & $21,47^{* * *}$ & $-3,91^{*}$ & $2,81^{* *}$ & $-0,15$ & $15,84 * * *$ & 1,01 \\
\hline & {$[1,14]$} & {$[0,22]$} & {$[8,00]$} & {$[2,09]$} & {$[1,33]$} & {$[0,13]$} & {$[5,09]$} & {$[0,86]$} \\
\hline \multirow[t]{2}{*}{ Jovens } & $-0,12$ & $-0,05$ & 0,12 & $-0,04$ & 0,09 & 0,06 & 0,10 & $-0,02$ \\
\hline & {$[0,42]$} & {$[0,42]$} & {$[0,42]$} & {$[0,42]$} & {$[0,42]$} & {$[0,42]$} & {$[0,41]$} & {$[0,41]$} \\
\hline \multirow[t]{2}{*}{ Urbanização } & $0,25^{* *}$ & $0,34^{* * *}$ & $0,22^{*}$ & $0,38 * * *$ & 0,10 & $0,40 * * *$ & 0,12 & $0,30 * * *$ \\
\hline & & {$[0,11]$} & {$[0,12]$} & {$[0,11]$} & {$[0,17]$} & & {$[0,12]$} & {$[0,11]$} \\
\hline \multirow[t]{2}{*}{ População } & $-15,91^{* * *}$ & $-18,97^{* * *}$ & $-18,17^{* * *}$ & $-19,21^{* * *}$ & $-19,15^{* * *}$ & $-20,55^{* * *}$ & $-24,64^{* * *}$ & $-20,71^{* * *}$ \\
\hline & {$[2,82]$} & {$[2,57]$} & {$[2,62]$} & & & & & \\
\hline \multirow[t]{2}{*}{ Constante } & 72,14 & $209,25^{* * *}$ & 60,64 & $246,18^{* * *}$ & $224,57^{* * *}$ & $226,77^{* * *}$ & $223,68^{* * * *}$ & $232,75^{* * * *}$ \\
\hline & {$[62,44]$} & {$[32,70]$} & {$[66,68]$} & {$[34,07]$} & {$[29,92]$} & {$[29,80]$} & {$[29,99]$} & {$[30,09]$} \\
\hline$R^{2}$ & 0,938 & 0,937 & 0,938 & 0,937 & 0,941 & 0,941 & 0,937 & 0,936 \\
\hline \multirow[t]{2}{*}{ Observações } & 2.088 & 2.088 & 2.088 & 2.088 & 2.088 & 2.088 & 2.088 & 2.088 \\
\hline & Pain & C: Variac & ต̆ & nal do i & cador es & nômico & & \\
\hline \multirow[t]{2}{*}{ dummy 2002} & $-29,62^{* * *}$ & $-28,92^{* * *}$ & $-24,03^{* * *}$ & $-28,92^{* * *}$ & $-28,98^{* * *}$ & $-29,33^{* * *}$ & $-25,35^{* * *}$ & $-28,65^{* * *}$ \\
\hline & & {$[1,25]$} & {$[2,22]$} & {$[1,26]$} & {$[1,26]$} & {$[1,25]$} & {$[1,84]$} & {$[1,28]$} \\
\hline \multirow[t]{2}{*}{ Condição econômica } & $2,66 * * *$ & $-0,03$ & $1,04^{* * *}$ & 0,01 & $0,05^{* *}$ & $-0,01^{*}$ & $0,29 * * *$ & 0,01 \\
\hline & & {$[0,07]$} & {$[0,39]$} & {$[0,02]$} & {$[0,02]$} & {$[0,01]$} & {$[0,11]$} & {$[0,01]$} \\
\hline Jovens & $-0,10$ & $-0,02$ & 0,28 & $-0,03$ & $-0,21$ & $-0,15$ & 0,30 & 0,03 \\
\hline & & {$[0,42]$} & & {$[0,42]$} & {$[0,41]$} & {$[0,41]$} & {$[0,44]$} & {$[0,42]$} \\
\hline Urbanização & $0,25^{* *}$ & $0,35^{* * *}$ & $0,40^{* * *}$ & $0,35 * * *$ & $0,54^{* * *}$ & $0,35^{* * *}$ & $0,32^{* * *}$ & $0,36 * * *$ \\
\hline & & {$[0,11]$} & {$[0,1]_{1}$} & & & & {$[0,11]$} & {$[0,11]$} \\
\hline População & $-15,18^{* * *}$ & $-19,03^{* * *}$ & $-10,04^{* *}$ & $-19,05 * * *$ & $-11,12^{* *}$ & $-20,37^{* * *}$ & $-14,73^{* * *}$ & $-18,81^{* * *}$ \\
\hline & {$[2,88]$} & {$[2,56]$} & {$[4, J J]$} & {$[2,56]$} & {$[4,60]$} & {$[2,36]$} & {$[3,07]$} & {$[2,58]$} \\
\hline Constante & $191,37^{* * *}$ & $217,42^{* * *}$ & $112,37^{* *}$ & $218,13^{* * *}$ & $133,65^{* *}$ & $236,86^{* * *}$ & $163,77^{* * * *}$ & $212,89^{*} * *$ \\
\hline & & {$[30,77]$} & {$[50,87]$} & {$[31,02]$} & {$[53,15]$} & {$[29,45]$} & {$[36,82]$} & {$[31,14]$} \\
\hline$R^{2}$ & 0,938 & 0,937 & 0,938 & 0,937 & 0,943 & 0,943 & 0,938 & 0,937 \\
\hline Observações & 2.088 & 2.088 & 2.088 & 2.088 & 2.088 & 2.088 & 2.088 & 2.088 \\
\hline
\end{tabular}

Fonte: elaboração própria

Nota: a variável dependente das regressões é a proporção de votos recebidas pelo partido incumbente nas eleições presidenciais de 1998 e 2002, por município; IV se refere à Variável Instrumental e OLS se refere a Mínimos Quadrados Ordinários; Erro-padrão obtido via block bootstrap com 5.000 replicações entre colchetes; $*^{* *}=$ Significante a $1 \% ; * *=$ Significante a $5 \% ; *=$ Significante a $10 \%$. 
Tabela 30 - Efeito das condições econômicas sobre a performance eleitoral - Variável instrumental e OLS - efeitos fixos - faixas populacionais selecionadas

\begin{tabular}{|c|c|c|c|c|c|c|c|c|}
\hline \multirow[t]{2}{*}{$\begin{array}{c}\text { Coeficiente } \\
{[\text { Erro-padrão] }}\end{array}$} & \multicolumn{2}{|c|}{$\begin{array}{c}\text { Horas } \\
\text { contratadas }\end{array}$} & \multicolumn{2}{|c|}{$\begin{array}{l}\text { Salário } \\
\text { médio }\end{array}$} & \multicolumn{2}{|c|}{$\begin{array}{l}\text { Emprego } \\
\text { indústria }\end{array}$} & \multicolumn{2}{|c|}{$\begin{array}{l}\mathrm{N}^{\mathrm{o}} \text { usuários } \\
\text { industriais }\end{array}$} \\
\hline & IV & OLS & IV & OLS & IV & OLS & IV & OLS \\
\hline \multicolumn{9}{|c|}{ Até 10.000 habitantes } \\
\hline \multicolumn{9}{|c|}{ Painel A: Indicador econômico do ano eleitoral } \\
\hline Condição econômica & $\begin{array}{c}4,30^{* * *} \\
{[1,44]}\end{array}$ & $\begin{array}{c}0,02 \\
{[0,19]}\end{array}$ & $\begin{array}{c}55,26^{* * *} \\
{[18,79]}\end{array}$ & $\begin{array}{c}-4,86^{* *} \\
{[2,46]}\end{array}$ & $\begin{array}{c}6,00^{* * *} \\
{[2,03]}\end{array}$ & $\begin{array}{l}-0,16 \\
{[0,12]}\end{array}$ & $\begin{array}{c}21,48^{* * *} \\
{[7,27]}\end{array}$ & $\begin{array}{c}0,72 \\
{[1,04]}\end{array}$ \\
\hline$R^{2}$ & 0,921 & 0,920 & 0,921 & 0,920 & 0,924 & 0,922 & 0,921 & 0,920 \\
\hline Observações & 1.022 & 1.022 & 1.022 & 1.022 & 959 & 959 & 1.021 & 1.021 \\
\hline \multicolumn{9}{|c|}{ Painel B: Indicador econômico da média dos dois últimos anos do mandato } \\
\hline Condição econômica & $4,20^{* *}$ & 0,05 & $29,40^{* *}$ & $-6,91^{* *}$ & $4,18^{* *}$ & $-0,20$ & $21,97^{* * *}$ & 0,40 \\
\hline & {$[1,72]$} & {$[0,28]$} & {$[11,94]$} & {$[2,89]$} & {$[2,06]$} & {$[0,15]$} & {$[7,34]$} & {$[1,08]$} \\
\hline$R^{2}$ & 0,922 & 0,921 & 0,922 & 0,922 & 0,928 & 0,927 & 0,921 & 0,920 \\
\hline Observações & 1.022 & 1.022 & 1.022 & 1.022 & 959 & 959 & 1.021 & 1.021 \\
\hline \multicolumn{9}{|c|}{ Painel C: Variação proporcional do indicador econômico } \\
\hline Condição econômica & $3,64^{* *}$ & $-0,09$ & $1,43^{* *}$ & $-0,02$ & $0,07^{* *}$ & $-0,01^{*}$ & $0,40^{* *}$ & 0,01 \\
\hline & {$[1,48]$} & {$[0,09]$} & {$[0,58]$} & {$[0,02]$} & {$[0,03]$} & {$[0,01]$} & {$[0,17]$} & {$[0,01]$} \\
\hline$R^{2}$ & 0,922 & 0,921 & 0,922 & 0,921 & 0,932 & 0,931 & 0,922 & 0,921 \\
\hline Observações & 1.022 & 1.022 & 1.022 & 1.022 & 959 & 959 & 1.021 & 1.021 \\
\hline \multicolumn{9}{|c|}{ Entre 10.000 e 50.000 habitantes } \\
\hline \multicolumn{9}{|c|}{ Painel D: Indicador econômico do ano eleitoral } \\
\hline Condição econômica & $3,08 * *$ & 0,31 & $39,55^{* *}$ & $-5,10$ & $3,62^{*}$ & $-0,02$ & $15,48^{* *}$ & 2,06 \\
\hline & {$[1,50]$} & {$[0,33]$} & {$[19,33]$} & {$[3,13]$} & {$[1,95]$} & {$[0,14]$} & {$[7,56]$} & {$[1,50]$} \\
\hline$R^{2}$ & 0,947 & 0,946 & 0,947 & 0,947 & 0,948 & 0,947 & 0,947 & 0,946 \\
\hline Observações & 774 & 774 & 774 & 774 & 773 & 773 & 774 & 774 \\
\hline \multicolumn{9}{|c|}{ Painel E: Indicador econômico da média dos dois últimos anos do mandato } \\
\hline Condição econômica & $3,98^{* *}$ & 0,45 & $27,84^{* *}$ & $-1,45$ & $4,15^{* *}$ & 0,03 & $15,83^{* *}$ & 2,62 \\
\hline & {$[1,72]$} & {$[0,37]$} & {$[11,69]$} & {$[3,40]$} & {$[1,92]$} & {$[0,22]$} & {$[7,67]$} & {$[1,60]$} \\
\hline$R^{2}$ & 0,947 & 0,946 & 0,947 & 0,946 & 0,947 & 0,947 & 0,947 & 0,947 \\
\hline Observações & 774 & 774 & 774 & 774 & 773 & 773 & 774 & 774 \\
\hline \multicolumn{9}{|c|}{ Painel F: Variação proporcional do indicador econômico } \\
\hline Condição econômica & $3,45^{* *}$ & 0,07 & $1,35^{* *}$ & $0,04^{*}$ & $0,07^{* *}$ & $-0,01^{* *}$ & $0,38^{* *}$ & $0,03^{*}$ \\
\hline & {$[1,48]$} & {$[0,10]$} & {$[0,58]$} & {$[0,02]$} & {$[0,03]$} & {$[0,01]$} & {$[0,16]$} & {$[0,02]$} \\
\hline$R^{2}$ & 0,947 & 0,946 & 0,947 & 0,946 & 0,947 & 0,948 & 0,947 & 0,946 \\
\hline Observações & 774 & 774 & 774 & 774 & 773 & 773 & 774 & 774 \\
\hline
\end{tabular}

Fonte: elaboração própria

Nota: a variável dependente das regressões é a proporção de votos recebidas pelo partido incumbente nas eleições presidenciais de 1998 e 2002, por município; IV se refere à Variável Instrumental e OLS se refere a Mínimos Quadrados Ordinários; Erro-padrão obtido via block bootstrap com 5.000 replicações entre colchetes; ${ }^{* * *}=$ Significante a $1 \% ; * *=$ Significante a $5 \%{ }^{*}=$ Significante a $10 \%$. 


\section{Considerações finais da tese}

O objetivo desta tese foi apresentar três estudos em que interagem as áreas de Economia do Setor Público e Nova Economia Política. O Capítulo 2 teve o objetivo de analisar em que medida o alinhamento partidário entre os prefeitos dos municípios brasileiros e o chefe do executivo federal e/ou os chefes do executivo de seus respectivos estados exerce efeito sobre o volume de transferências fiscais. Os resultados obtidos sugerem que muito embora o efeito do alinhamento sobre a rubrica Outras transferências correntes seja em geral nulo, as Transferências de capital recebidas pelos municípios do Brasil tendem a ser maiores caso seus prefeitos sejam do mesmo partido do chefe do executivo federal ou então, dos partidos dos chefes do executivo de seus respectivos estados. Conforme mencionado ao longo do referido capítulo, uma contribuição importante deste estudo foi adotar um método que permite explorar todas as fontes de variação existentes (quais sejam, entre diferentes unidades seccionais, entre diferentes períodos de tempo e entre diferentes níveis de governo), bem como explorar dois tipo distintos de transferências (corrente e de capital). Ademais, a análise das transferências recebidas pelos municípios brasileiros a partir de seus respectivos governos estaduais também pode ser vista como outra contribuição do estudo, dado que estes valores têm sido pouco investigados pela literatura.

O Capítulo 3, por sua vez, teve motivação semelhante ao estudo realizado no primeiro. Em particular, o objetivo foi analisar em que medida o alinhamento partidário dos prefeitos municipais e governadores estaduais com o governo federal influencia a obtenção de financiamento junto ao BNDES. Os resultados obtidos por meio de diferentes métodos econométricos sugerem que municípios cujos prefeitos são alinhados com o governo federal são mais propensos a solicitar tais financiamentos (e serem atendidos) comparativamente a municípios cujos chefes de executivo não são alinhados. Por seu turno, estados cujos governadores são alinhados com o governo federal parecem não só receber financiamentos maiores comparativamente a estados cujos governadores não são alinhados com o governo federal, mas também sujeitos à menores taxas de juros e maiores prazos de amortização. Os resultados obtidos sugerem que, ceteris paribus, ou seja, mantidas constantes as características dos municípios e estados brasileiros, instituições governamentais responsáveis pela viabilização de importantes políticas de investimento e de desenvolvimento podem estar sendo geridas de tal forma a beneficiar unidades de governo politicamente alinhadas com o governo federal. Assim, analisados em conjunto com aqueles apresentados no Capítulo 2, estes resultados sinalizam que o alinhamento partidário pode estar exercendo um efeito não desprezível sobre a condução de determinadas políticas, causando possíveis distorções sobre o papel do governo.

Finalmente, o Capítulo 4 desta tese teve como objetivo trazer novas contribuições à literatura de economic voting procurando investigar em que medida condições econômicas influenciam a decisão de voto por parte dos eleitores. Em particular, o estudo explorou mudanças exógenas das condições econômicas causadas pela instituição do programa de racionamento de energia elétrica, instituído entre junho de 2001 e fevereiro de 2002, para analisar o desempenho do candidato incumbente nas eleições para Presidente da República de 1998 e 2002 nos municípios paulistas e paranaenses, os quais fizeram e 
não fizeram, respectivamente, parte do referido programa. Combinando os métodos de Diferenças-em-Diferenças e Variáveis Instrumentais, os resultados obtidos sugerem que melhores condições econômicas efetivamente aumentam o sucesso eleitoral de candidatos incumbentes. Mais do que isto, esse efeito pode ter sido subestimado pela literatura até então existente dado que os resultados obtidos por meio do método aqui posto em prática revela resultados significativamente diferentes dos obtidos por métodos usualmente adotados por referências já existentes na literatura de economic voting (estimações tradicionais do tipo OLS). Assim, entende-se que este estudo contribui com a literatura ao promover a discussão de uma possível endogeneidade da relação entre condições econômica e performance eleitoral de incumbentes e a necessidade de métodos adequados para estimá-la corretamente.

Características específicas dos capítulos à parte, dado que o processo de escolha das lideranças governamentais envolve vários fatores de natureza política, torna-se natural considerá-los como elementos que também afetem, em maior ou menor grau, a forma com a qual governantes formulam e executam políticas públicas. A avaliação de tais fatores à luz da interação entre Economia do setor público e Ciência Política deve ser vista, portanto, como a principal contribuição dos estudos aqui apresentados. Conforme mencionado na introdução desta tese, espera-se que os resultados aqui apresentados sejam importantes não só em termos puramente acadêmicos, mas também para o processo de formulação, execução, acompanhamento e reforma das políticas públicas.

Por fim, ressalta-se que os estudos desenvolvidos nesta tese estão em consonância com a linha de atuação do autor dado que há uma estreita ligação desses com aqueles já desenvolvidos ao longo de sua carreira acadêmica. Neste sentido, nota-se que o autor apresenta consistência quanto à sua área de atuação que, conforme mencionado anteriormente, tem crescido de forma significativa na literatura internacional e nacional ao longo dos últimos anos. 


\section{Referências}

AGHION, P.; HOWITT, P. A model of growth through creative destruction. Econometrica, v. 60, n. 2, p. 323-351, 1992.

AIDT, T. S.; VEIGA, F. J.; VEIGA, L. G. Election results and opportunistic policies: a new test of the rational political business cycle model. Public Choice, v. 148, n. 1-2, p. 21-44, July 2010.

ANTUNES, A.; CAVALCANTI, T.; VILLAMIL, A. The effects of credit subsidies on development. Economic Theory, Springer Berlin Heidelberg, v. 58, n. 1, p. 1-30, 2015. ISSN 0938-2259. Disponível em: < http://dx.doi.org/10.1007/s00199-014-0808-0>.

ARRETCHE, M.; SCHLEGEL, R.; FERRARI, D. Preferences regarding the vertical distribution of authority in Brazil: on measurement and determinants. Publius: The Journal of Federalism, 2015. Disponível em: < http://publius.oxfordjournals.org/content/early/ 2015/08/06/publius.pjv033.abstract $>$.

ARTES, J. The rain in Spain: turnout and partisan voting in Spanish elections. European Journal of Political Economy, v. 34, p. 126-141, 2014.

ARULAMPALAM, W. et al. Electoral goals and center-state transfers: a theoretical model and empirical evidence from India. Journal of Development Economics, v. 1, n. 88, p. 103119, 2009.

ARVATE, P. R.; BARBOSA, K. d. S.; FUZITANI, E. Party expertise, campaign donation and government contracts: evidence from an electoral quasi-experiment. 2016.

AUBERGER, A.; DUBOIS, E. The influence of local and national economic conditions on French legislative elections. Public Choice, v. 125, n. 3, p. 363-383, 2005. ISSN 1573-7101. Disponível em: <http://dx.doi.org/10.1007/s11127-005-3056-9>.

BAER, W. A industrialização e o desenvolvimento econômico no Brasil. [S.l.]: Editora da Fundação Getúlio Vargas, 1988.

BARBOSA-FILHO, M. C. Uma avaliação do Programa de Modernização da Administração Tributária (PMAT) sobre o esforço fiscal dos municípios (2000 a 2010). Dissertação (Mestrado) - Mestrado em Economia - Faculdade de Economia Administração e Contabilidade - Departamento de Economia - Universidade de Brasília, 2013.

BARDELIN, C. E. A. Os efeitos do racionamento de energia elétrica ocorrido no Brasil em 2001 e 2002 com ênfase no consumo de energia elétrica. Dissertação (Mestrado) Escola Politécnica - Universidade de São Paulo, 2004.

BARRO, R. J. Government spending in a simple model of endogeneous growth. Journal of Political Economy, University of Chicago Press, v. 98, n. 5, p. S103-S125, 1990. ISSN 00223808, 1537534X. Disponível em: <http://www.jstor.org/stable/2937633>.

BARRO, R. J.; MANKIW, N. G.; MARTIN, X. Sala-i. Capital mobility in neoclassical models of growth. The American Economic Review, American Economic Association, v. 85, n. 1, p. 103-115, 1995. ISSN 00028282. Disponível em: <http://www.jstor.org/ stable/2117998>. 
BAST, M. T. N. Uma avaliação empírica dos efeitos dos empréstimos do BNDES aos governos municipais brasileiros. Dissertação (Mestrado) - Faculdade de Economia, Administração e Contabilidade de Ribeirão Preto - Universidade de São Paulo, 2015.

BERTRAND, M.; DUFLO, E.; MULLAINATHAN, S. How much should we trust Differences-in-Differences estimates? The Quarterly Journal of Economics, v. 119, n. 1, p. 249-275, 2004. Disponível em: <http://qje.oxfordjournals.org/content/119/1/249. abstract $>$.

BONELLI, R.; PINHEIRO, A. C. O papel da poupança compulsória ao financiamento do desenvolvimento: desafios para o BNDES. Revista do BNDES, v. 1, n. 1, p. 17-36, 1994.

BRENDER, A.; DRAZEN, A. How do budget deficits and economic growth affect reelection prospects? Evidence from a large panel of countries. The American Economic Review, v. 98, n. 5, p. 2203-2220, 2008.

BROCK, W. A.; TAYLOR, M. S. The green Solow model. Journal of Economic Growth, Springer, v. 15, n. 2, p. 127-153, 2010. ISSN 13814338, 15737020. Disponível em: < http: //www.jstor.org/stable/40731382>.

BROLLO, F.; NANNICINI, T. Tying your enemy's hands in close races: the politics of federal transfers in Brazil. American Political Science Review, v. 106, n. 04, p. 742-761, 2012.

BRUCK, N. Role of development banks in the twenty-first century. Journal of Emerging Markets, v. 3, p. 39-67, 1998. Disponível em: <www.scopus.com>.

CALONICO, S.; CATTANEO, M. D.; TITIUNIK, R. Robust nonparametric confidence intervals for regression-discontinuity designs. Econometrica, Blackwell Publishing Ltd, v. 82, n. 6, p. 2295-2326, 2014. ISSN 1468-0262. Disponível em: <http://dx.doi.org/10. 3982/ECTA11757>.

CAMERON, A. C.; TRIVEDI, P. K. Microeconometrics: Methods and Applications. [S.1.]: Cambridge University Press, 2005.

CARVALHO, D. The real effects of government-owned banks: evidence from an emerging market. The Journal of Finance, v. 69, n. 2, p. 577-609, 2014. ISSN 1540-6261. Disponível em: <http://dx.doi.org/10.1111/jofi.12130>.

CERDA, R.; VERGARA, R. Business cycle and political election outcomes: evidence from the Chilean democracy. Public Choice, v. 132, p. 125-136, 2007.

COELHO, D.; NEGRI, J. A. Impacto do financiamento do BNDES sobre a produtividade das empresas: uma aplicação do efeito quantílico de tratamento. 2010.

COLE, S. Fixing market failures or fixing elections? Agricultural credit in India. American Economic Journal: Applied Economics, American Economic Association, v. 1, n. 1, p. 219-250, 2009. ISSN 19457782, 19457790. Disponível em: <http://www.jstor.org/stable/ $25760153>$.

COSTA, F.; GERARD, F. Hysterersis and the social cost of corrective policies: evidence from a temporary energy saving program. 2015. Disponível em: < http://papers.ssrn.com/ sol3/papers.cfm?abstract_id $=2666704>$. 
COX, G. W.; McCUBBINS, M. D. G. Legislative Leviathan: party government in the House. [S.1.]: University of California Press, 1993.

CURRALERO, C. R. B. A atuação do sistema BNDES como instituição financeira de fomento no período 1952/1996. Dissertação (Mestrado) - Instituto de Economia - Universidade Estadual de Campinas, 1998.

DINC, I. S. Politicians and banks: Political influences on government-owned banks in emerging markets. Journal of Financial Economics, v. 77, n. 2, p. 453 - 479, 2005. ISSN 0304-405X. Disponível em: <http://www.sciencedirect.com/science/article/ pii/S0304405X05000498>.

DIXIT, A.; LONDREGAN, J. The determinants of success of special interests in redistributive politics. The Journal of Politics, The University of Chicago Press, v. 58, n. 4, p. 1132-1155, 1996. ISSN 00223816, 14682508. Disponível em: <http://www.jstor.org/ stable/2960152>.

DIXIT, A.; LONDREGAN, J. Fiscal federalism and redistributive politics. Journal of Public Economics, v. 68, n. 2, p. 153 - 180, 1998. ISSN 0047-2727. Disponível em: < http: //www.sciencedirect.com/science/article/pii/S0047272797000972>.

DUCHATEAU, P.; AGUIRRE, B. M. B. Estrutura politica como determinante dos gastos federais. Revista EconomiA, v. 11, n. 2, p. 305-331, 2010.

DUTTA, B. The fragmented Lok Sabha: a case for electoral engineering. Economic and Political Weekly, v. 154, n. 17, p. 93-100, 2009.

ELINDER, M. Local economies and general elections: the influence of municipal and regional economic conditions on voting in Sweden 1985-2002. European Journal of Political Economy, v. 26, n. 2, p. 279 - 292, 2010. ISSN 0176-2680. Disponível em: <http://www. sciencedirect.com/science/article/pii/S0176268010000042>.

FAIR, R. C. The effect of economic events on votes for president. The Review of Economics and Statistics, The MIT Press, v. 60, n. 2, p. 159-173, 1978. ISSN 00346535, 15309142. Disponível em: <http://www.jstor.org/stable/1924969>.

FEREJOHN, J. Pork barrel politics: rivers and harbors legislation, 1947-1968. Stanford, CA: Stanford University Press, 1974.

FERREIRA, C. K. L. O financiamento da indústria e infra-estrutura no Brasil: crédito de longo prazo e mercado de capitais. Tese (Doutorado) - Instituto de Economia - Universidade Estadual de Campinas, 1995.

FERREIRA, I. F. S.; BUGARIN, M. S. Transferências voluntárias e ciclo políticoorçamentário no federalismo fiscal brasileiro. Revista Brasileira de Economia, v. 61, n. 3, p. 271-300, 2007.

FIORINA, M. P. Retrospective voting in American national elections. New Haven, CT: Yale University Press, 1981.

FRANCK, R. The political consequences of income shocks: Explaining the consolidation of democracy in France. Review of Economics and Statistics, MIT Press, v. 98, n. 1, p. 57-82, ago. 2016. ISSN 0034-6535. Disponível em: <http://dx.doi.org/10.1162/REST_ a_00477>. 
FUJIWARA, T. Voting technology, political responsiveness and infant health: evidence from Brazil. Econometrica, Blackwell Publishing Ltd, v. 83, n. 2, p. 423-464, 2015. ISSN 1468-0262. Disponível em: <http://dx.doi.org/10.3982/ECTA11520>.

GADENNE, L. Tax me, but spend wisely? Sources of public finance and government accountability. 2015.

GELINEAU, F.; BELANGER, E. Electoral accountability in a federal system: national and provincial economic voting in Canada. Publius, [CSF Associates Inc., Oxford University Press], v. 35, n. 3, p. 407-424, 2005. ISSN 00485950, 17477107. Disponível em: $<$ http://www.jstor.org/stable/4624720>.

GROSE, C. R.; OPPENHEIMER, B. I. The Iraq war, partisanship and candidate attributes: variation in partisan swing in the 2006 U.S. House elections. Legislative Studies Quarterly, Comparative Legislative Research Center, v. 32, n. 4, p. 531-557, 2007. ISSN 03629805. Disponível em: < http://www.jstor.org/stable/40263437>.

GROSSMAN, P. J. A political theory of intergovernmental grants. Public Choice, v. 78, p. 295-303, 1994.

HEALY, A.; MALHOTRA, N. Myopic voters and natural disaster policy. American Political Science Review, v. 103, n. 3, p. 387-406, August 2009.

HERMANN, J. Bancos públicos em sistemas financeiros maduros: perspectivas teóricas e desafios para os países em desenvolvimento. Revista de Economia Política, scielo, v. 31, p. 397 - 414, 09 2011. ISSN 0101-3157. Disponível em: <http://www.scielo.br/scielo.php? script $=$ sci_arttext\&pid $=$ S0101-31572011000300005\&nrm $=\mathrm{iso}>$.

HERWARTZ, H.; THEILEN, B. On the political and fiscal determinants of income redistribution under federalism and democracy: evidence from Germany. Public Choice, v. 159, n. 1, p. 121-139, 2012. ISSN 1573-7101. Disponível em: <http://dx.doi.org/10. $1007 / \mathrm{s} 11127-012-0031-0>$.

IMBENS, G.; KALYANARAMAN, K. Optimal bandwidth choice for the regression discontinuity estimator. The Review of Economic Studies, v. 79, n. 3, p. 933-959, 2012. Disponível em: <http://restud.oxfordjournals.org/content/79/3/933.abstract>.

IMBENS, G. W.; LEMIEUX, T. Regression discontinuity designs: a guide to practice. Journal of Econometrics, v. 142, p. 615-635, 2008.

INOUE, C. F. K. V.; LAZZARINI, S. G.; MUSACCHIO, A. Leviathan as a minority shareholder: firm-level implications of State equity purchases. Academy of Management Journal, v. 56, n. 6, p. 1775-1801, 2013. Disponível em: <http://amj.aom.org/content/ $56 / 6 / 1775$.abstract $>$.

JOHANSSON, E. Intergovernmental grants as a tactical instrument: empirical evidence from Swedish municipalities. Journal of Public Economics, v. 5-6, n. 87, p. 883-915, 2003.

JORDAHL, H. An economic analysis of voting in Sweden. Public Choice, v. 127, p. 251273, 2006. 
KAROL, D.; MIGUEL, E. The electoral cost of war: Iraq casualties and the 2004 U.S. presidential election. The Journal of Politics, The University of Chicago Press, v. 69, n. 3, p. 633-648, 2007. ISSN 00223816, 14682508. Disponível em: < http://www.jstor. org/stable/4622569>.

KEY, V. O. The responsible electorate: rationality in presidential voting, 1936-1960. Belknap Press, 1966. Hardcover. ISBN 0674766504. Disponível em: <http://www.amazon. com/exec/obidos/redirect?tag=citeulike07-20\&path=ASIN/0674766504>.

KHEMANI, S. Does delegation of fiscal policy to an independent agency make a difference? Evidence from intergovernmental transfers in India. Journal of Development Economics, v. 82, n. 2, p. 464-484, 2007.

KHWAJA, A. I.; MIAN, A. Do lenders favor politically connected firms? Rent provision in an emerging financial market. The Quarterly Journal of Economics, Oxford University Press, v. 120, n. 4, p. 1371-1411, 2005. ISSN 00335533, 15314650. Disponível em: < http: //www.jstor.org/stable/25098774>.

KLAAUW, W. Van der. Regression Discontinuity Analysis: a survey of recent developments in Economics. Labour, Blackwell Publishing Ltd, v. 22, n. 2, p. 219-245, 2008. ISSN 1467-9914. Disponível em: <http://dx.doi.org/10.1111/j.1467-9914.2008.00419.x>.

KRAMER, G. H. Short-term fluctuations in U.S. voting behavior, 1896-1964. The American Political Science Review, [American Political Science Association, Cambridge University Press], v. 65, n. 1, p. 131-143, 1971. ISSN 00030554, 15375943. Disponível em: $<$ http://www.jstor.org/stable/1955049>.

LAAKSO, M.; TAAGEPERA, R. "Effective" number of candidates. a measure with application to west europe. Comparative Political Studies, v. 12, n. 1, p. 3-27, 1979.

LARCINESE, V.; RIZZO, L.; TESTA, C. Allocating the U.S. federal budget to the states: the impact of the president. Journal of Politics, v. 68, n. 2, p. 447-456, 2006.

LAZZARINI, S. G. et al. What do State-owned development banks do? Evidence from BNDES, 2002-2009. World Development, v. 66, p. 237 - 253, 2015. ISSN 0305-750X. Disponível em: <http://www.sciencedirect.com/science/article/pii/S0305750X1400254X>.

LEAO, S.; MELLO, J. M. P.; FERRAZ, C. The effect of political alignment on public federal bank lending. 2013.

LESSA, C. 15 anos de política econômica. [S.l.]: Editora Brasiliense, 1983.

LEVITT, S. D.; SNYDER-JR., J. M. Political parties and the distribution of federal outlays. American Journal of Political Science, v. 39, n. 4, p. 958-980, 1995.

LEWIS-BECK, M. S. Economics and elections: the major Western democracies. Ann Arbor, MI: University of Michigan Press, 1988.

LI, H. et al. Political connections, financing and firm performance: evidence from Chinese private firms. Journal of Development Economics, v. 87, n. 2, p. 283 - 299, 2008. ISSN 0304-3878. Disponível em: <http://www.sciencedirect.com/science/article/ pii/S0304387807000259>. 
LUDWIG, J.; MILLER, D. L. Does head start improve children's life chances? evidence from a regression discontinuity design. The Quarterly Journal of Economics, v. 122, n. 1, p. 159-208, 2007. Disponível em: <http://qje.oxfordjournals.org/content/122/1/ 159.abstract>.

MALHOTRA, N.; KUO, A. G. Attributing blame: the public's response to hurricane Katrina. The Journal of Politics, v. 70, n. 1, p. 120-135, January 2008.

MANKIW, N. G.; ROMER, D.; WEIL, D. N. A contribution to the empirics of economic growth. The Quarterly Journal of Economics, Oxford University Press, v. 107, n. 2, p. 407-437, 1992. ISSN 00335533, 15314650. Disponível em: <http://www.jstor.org/stable/ $2118477>$.

MARTINS, R.; VEIGA, F. J. Economic voting in Portuguese municipal elections. Public Choice, Springer US, v. 155, n. 3-4, p. 317-334, 2013. ISSN 0048-5829. Disponível em: <http://dx.doi.org/10.1007/s11127-011-9849-0>.

McCRARY, J. Manipulation of the running variable in the regression discontinuity design: a density test. Journal of Econometrics, v. 142, n. 2, p. 698 - 714, 2008. ISSN 03044076. The regression discontinuity design: Theory and applications. Disponível em: $<$ http: //www.sciencedirect.com/science/article/pii/S0304407607001133>.

McKINNON, R. I. Money and capital in economic development. The Brookings Institution Press, 1973. ISBN 9780815718499. Disponível em: <https://books.google.co.uk/books? $\mathrm{id}=\operatorname{erOVIDIY1jEC}>$.

MEIER, A. Saving electricity in a hurry: dealing with temporary shortfalls in electricity supplies. [S.l.], 2005. Disponível em: < https://www.iea.org/publications/ freepublications/publication/savingelec.pdf $>$.

MENDES, M. J. Capture of fiscal transfers: a study of Brazilian local governments. Economia Aplicada, v. 9, n. 3, p. 427-444, 2005.

MICCO, A.; PANIZZA, U. Bank ownership and lending behavior. Economics Letters, v. 93, n. 2, p. 248 - 254, 2006. ISSN 0165-1765. Disponível em: <http://www.sciencedirect. com/science/article/pii/S0165176506001856>.

MIGUEIS, M. The effect of political alignment on transfers to Portuguese municipalities. Economics \&f Politics, v. 25, n. 1, p. 110-133, 2013. ISSN 1468-0343. Disponível em: <http://dx.doi.org/10.1111/ecpo.12005>.

MONTEIRO-FILHA, D. C. A aplicação de fundos compulsórios pelo BNDES na formação da estrutura setorial da indústria brasileira: 1952 a 1989. Tese (Doutorado) — Instituto de Economia Industrial da Universidade Federal do Rio de Janeiro, 1994.

MOREIRA, S. V.; TOMICH, F.; RODRIGUES, M. d. G. PROEX e BNDES-EXIM: construindo o futuro. [S.l.], 2006.

MOSER, P.; VOENA, A.; WALDINGER, F. German Jewish émigrés and U.S. invention. American Economic Review, v. 104, n. 10, p. 3222-55, 2014. Disponível em: <http:// www.aeaweb.org/articles.php?doi=10.1257/aer.104.10.3222>.

MUSGRAVE, R. A. The theory of Public Finance: a study in public economy. 1. ed. [S.l.]: McGraw-Hill, 1959. 
NAJBERG, S. Privatização de recursos públicos: os empréstimos do sistema BNDES ao setor privado nacional com correção monetária parcial. Dissertação (Mestrado) - PUCRJ, 1989.

NEGRI, J. A. et al. The Impact of Public Credit Programs on Brazilian Firms. [S.l.], 2011.

NICOLAU, J. Partidos na república de 1946: uma réplica metodológica. Dados, v. 48, n. 3, p. 589-608, 2005.

OATES, W. E. Fiscal federalism. [S.l.]: Harcourt Brace Jovanovich, 1972.

ODEDOKUN, M. International evidence on the effects of directed credit programmes on efficiency of resource allocation in developing countries: the case of development bank lendings. Journal of Development Economics, v. 48, n. 2, p. 449 - 460, 1996. ISSN 0304-3878. Disponível em: < http://www.sciencedirect.com/science/article/pii/0304387895000445>.

OtTAViAnO, G. I. P.; SOUSA, F. L. d. Políticas de incentivo à inovação tecnológica. In:___. [S.1.]: IPEA, 2008. cap. O efeito do BNDES na produtividade das empresas, p. $361-386$.

PELTZMAN, S. Voters as fiscal conservatives. The Quarterly Journal of Economics, v. 107, n. 2, p. 327-361, 1992.

PEREIRA, R. O. Ação do BNDES sobre o emprego formal: efeito nas empresas financiadas. Revista do BNDES, v. 14, n. 27, p. 27-42, Junho 2007.

PERSSON, M.; SUNDELL, A.; ÖHRVALL, R. Does election day weather affect voter turnout? Evidence from Swedish elections. Electoral Studies, v. 33, p. $335-342$, 2014. ISSN 0261-3794. Disponível em: <http://www.sciencedirect.com/science/article/ pii/S0261379413001212>.

PORTA, R. L.; SILANES, F. Lopez-de; SHLEIFER, A. Government ownership of banks. The Journal of Finance, Blackwell Publishers, Inc., v. 57, n. 1, p. 265-301, 2002. ISSN 1540-6261. Disponível em: <http://dx.doi.org/10.1111/1540-6261.00422>.

PORTO, A.; SANGUINETTI, P. Political determinants of intergovernmental grants: evidence from Argentina. Economics and Politics, v. 13, n. 3, p. 237-256, 2001.

RAE, D. W. The political consequences of electoral laws. [S.1.]: Yale University Press, 1971.

RAE, D. W. Using district magnitude to regulate political party competition. Journal of Economic Perspectives, v. 9, n. 1, p. 65-75, 1995.

REIFF, L. O. A.; SANTOS, G. A. G. a.; ROCHA, L. H. R. Emprego formal, qualidade de vida e o papel do BNDES. Revista do BNDES, v. 14, n. 27, p. 5-26, 2007.

REMMER, K. L.; GELINEAU, F. Subnational electoral choice: economic and referendum voting in Argentina, 1983-1999. Comparative Political Studies, v. 36, n. 7, p. 801-821, 2003. Disponível em: <http://cps.sagepub.com/content/36/7/801.abstract $>$.

RIBEIRO, E. P.; NEGRI, J. A. Public credit use and manufacturing productivity in Brazil. 2009.

ROGOFF, K. Equilibrium political budget cycles. American Economic Review, v. 80, n. 1, p. 21-36, 1990. 
ROMER, D. Advanced Macroeconomics. [S.l.]: McGraw-Hill/Irwin, 2012. The McGrawHill Series in Economics.

ROMER, P. M. Endogenous technological change. Journal of Political Economy, University of Chicago Press, v. 98, n. 5, p. S71-S102, 1990. ISSN 00223808, 1537534X. Disponível em: <http://www.jstor.org/stable/2937632>.

ROSEN, H. S.; GAYER, T. Public Finance. 9. ed. [S.l.]: McGraw-Hill, 2010.

ROZEVITCH, S.; WEISS, A. Beneficiaries from federal transfers to municipalities: the case of Israel. Public Choice, v. 76, n. 4, p. 335-346, 1993.

SAKURAI, S. N.; MENEZES-FILHO, N. A. Fiscal policy and reelection in Brazilian municipalities. Public Choice, v. 137, n. 1-2, p. 301-314, 2008.

SANTOS, W. G. Velhas teses, novos dados: uma análise metodológica. Dados, v. 47, n. 4, p. 729-762, 2004.

SAPIENZA, P. The effects of government ownership on bank lending. Journal of Financial Economics, v. 72, n. 2, p. 357 - 384, 2004. ISSN 0304-405X. Disponível em: <http://www. sciencedirect.com/science/article/pii/S0304405X03002459>.

SHAW, E. S. Financial deepening in economic development. The Oxford University Press, 1973. (Economic development report). Disponível em: <https://books.google.co. uk/books?id=Km9EAAAAIAAJ $>$.

SHLEIFER, A.; VISHNY, R. W. Politicians and firms. The Quarterly Journal of Economics, Oxford University Press, v. 109, n. 4, p. 995-1025, 1994. ISSN 00335533, 15314650. Disponível em: <http://www.jstor.org/stable/2118354>.

SILVA, C. E. L. Os financiamentos do BNDES e a inserção das firmas no comércio internacional: uma análise a partir de microdados. Economia \& Tecnologia, v. 21, p. 111-118, 2010 .

SILVA, C. E. L. O impacto do BNDES-EXIM no tempo de permanência das firmas brasileiras no mercado internacional: uma análise a partir dos microdados. Planejamento e políticas públicas, v. 1, n. 38, p. 9-35, 2012.

SMEETS, V.; WARZYNSKI, F. Job creation, job destruction and voting behavior in Poland. European Journal of Political Economy, v. 22, n. 2, p. 503 - 519, 2006. ISSN 0176-2680. Disponível em: <http://www.sciencedirect.com/science/article/ pii/S017626800500090X>.

SOLE-OLLE, A.; SORRIBAS-NAVARRO, P. The effects of partisan alignment on the allocation of intergovernmental transfers. Differences-in-Differences estimates for Spain. Journal of Public Economics, v. 92, p. 2302-2319, 2008.

SOLOW, R. M. A contribution to the theory of economic growth. The Quarterly Journal of Economics, Oxford University Press, v. 70, n. 1, p. 65-94, 1956. ISSN 00335533, 15314650. Disponível em: <http://www.jstor.org/stable/1884513>.

SOUSA, F. L. Custos, BNDES e produtividade. Textos para discussão No 267 - Faculdade de Economia - UFF. 2010. 
STIGLITZ, J. E. The role of the state in financial markets. In: THE WORLD BANK. Proceedings of the World Bank Annual Conference on Development Economics. Washington, D.C, 1994. p. 19-52. Disponível em: <http://www-wds.worldbank.org/external/default/ WDSContentServer/WDSP/IB/1994/03/01/000009265_3970702134931/Rendered/ $\mathrm{PDF} /$ multi_page.pdf $>$.

VEIGA, F. J.; VEIGA, L. G. Political business cycles at the municipal level. Public Choice, v. 131, p. 45-64, 2007.

VEIGA, F. J.; VEIGA, L. G. The impact of local and national economic conditions on legislative election results. Applied Economics, v. 42, n. 13, p. 1727-1734, 2010. Disponível em: <http://dx.doi.org/10.1080/00036840701736107>.

VEIGA, L. G.; PINHO, M. M. The political economy of intergovernmental grants: evidence from a maturing democracy. Public Choice, v. 133, n. 3-4, p. 457-477, 2007.

VIANA, A. L. d. O BNDE e a industrialização brasileira (1952-1961). Dissertação (Mestrado) - Departamento de Economia e Planejamento Econômico - Instituto de Filosofia e Ciências Humanas - Universidade Estadual de Campinas, 1981.

WALDINGER, F. Quality matters: the expulsion of professors and the consequences for PhD student outcomes in Nazi Germany. Journal of Political Economy, University of Chicago Press, v. 118, n. 4, p. 787-831, 2010. ISSN 00223808, 1537534X. Disponível em: <http://www.jstor.org/stable/10.1086/655976>.

WEGELIN, M. J. C. O impacto da política de crédito do BNDES no desenvolvimento econômico e social dos municípios brasileiros. Dissertação (Mestrado) - IBMEC-RJ, 2014.

WOOLDRIDGE, J. M. Econometric Analysis of Cross Section and Panel Data. [S.l.]: The MIT Press, 2010. 
Apêndices 
Apêndice A: Tabelas e figuras complementares do Capítulo 2 


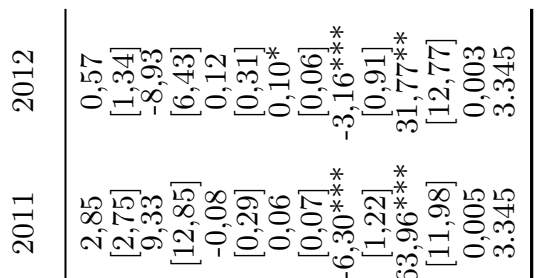

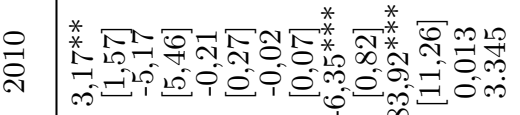

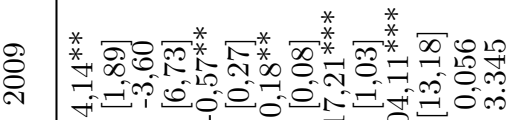

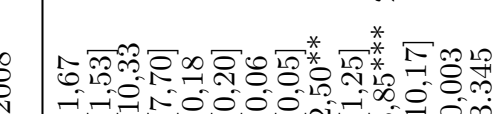

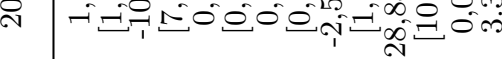

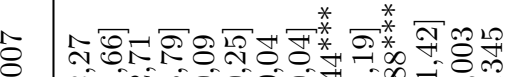

ก

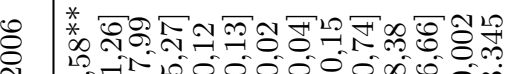

N

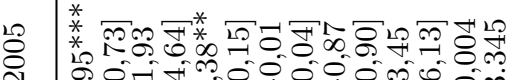

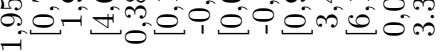

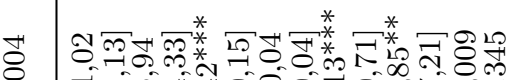

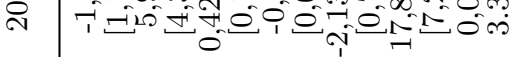

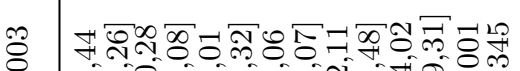

०

ڤิ

० ०100000 $000 \%$

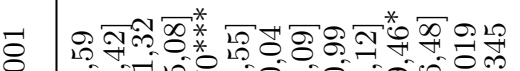

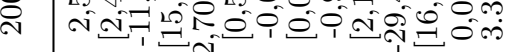

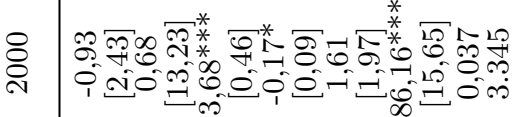

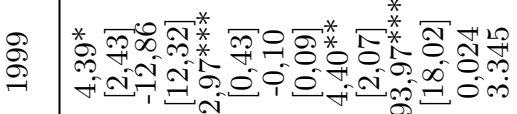

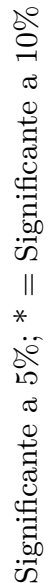

苂

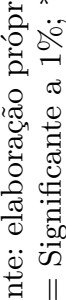

定

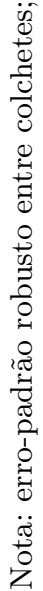


Tabela A.2 - Procedimento Time D - Outras transferências correntes do governo federal - alinhamento com coligação ou ministros

\begin{tabular}{cccccc}
\hline $\begin{array}{c}\text { Coeficiente } \\
\text { [Erro-padrão] }\end{array}$ & $2000-2001$ & $2002-2003$ & $2004-2005$ & $2006-2007$ & $2008-2011$ \\
\hline Alinhamento & 0,55 & $-5,07$ & 0,95 & $-4,21^{* *}$ & $8,20^{* * *}$ \\
& {$[2,44]$} & {$[3,51]$} & {$[1,14]$} & {$[1,86]$} & {$[2,21]$} \\
Fragmentação & 3,57 & 3,49 & $-5,73$ & 5,99 & 3,46 \\
& {$[11,99]$} & {$[10,27]$} & {$[4,48]$} & {$[8,79]$} & {$[7,68]$} \\
Jovens & $-0,32$ & $-0,10$ & 0,15 & $-0,19$ & $0,33^{* *}$ \\
& {$[0,65]$} & {$[0,38]$} & {$[0,15]$} & {$[0,24]$} & {$[0,16]$} \\
Urbanização & 0,04 & $0,20^{* * *}$ & 0,03 & 0,01 & 0,01 \\
& {$[0,10]$} & {$[0,08]$} & {$[0,04]$} & {$[0,04]$} & {$[0,05]$} \\
População & $-0,84$ & 0,14 & $1,61^{*}$ & $-1,93^{*}$ & $-5,60^{* * *}$ \\
& {$[2,29]$} & {$[1,46]$} & {$[0,86]$} & {$[1,16]$} & {$[0,92]$} \\
Constante & 11,48 & $-28,97$ & $-23,83^{* * *}$ & $20,69^{*}$ & $53,98^{* * *}$ \\
$R^{2}$ & {$[15,79]$} & {$[18,62]$} & {$[7,86]$} & {$[11,92]$} & {$[8,18]$} \\
Observações & 0,001 & 0,003 & 0,004 & 0,002 & 0,007 \\
\hline
\end{tabular}

Fonte: elaboração própria

Nota: erro-padrão robusto entre colchetes; $* * *=$ Significante a $1 \% ; * *=$ Significante a $5 \% ; *=$ Significante a $10 \%$

Tabela A.3 - Procedimento Triple D - Outras transferências correntes do governo federal - alinhamento com coligação ou ministros

\begin{tabular}{cccccc}
\hline $\begin{array}{c}\text { Coeficiente } \\
\text { [Erro-padrão] }\end{array}$ & $2000-2001$ & $2002-2003$ & $2004-2005$ & $2006-2007$ & $2008-2011$ \\
\hline \multirow{2}{*}{ Alinhamento } & $-1,51$ & $-2,17$ & $-0,18$ & $-0,47$ & $4,32^{* *}$ \\
& {$[2,31]$} & {$[1,80]$} & {$[0,92]$} & {$[1,02]$} & {$[1,70]$} \\
Fragmentação & 4,90 & 7,62 & 2,10 & 9,97 & 4,68 \\
& {$[13,54]$} & {$[10,44]$} & {$[6,23]$} & {$[9,47]$} & {$[7,83]$} \\
Jovens & $-0,97$ & $-0,60$ & $-0,06$ & $-0,04$ & $0,37^{* *}$ \\
& {$[0,70]$} & {$[0,37]$} & {$[0,18]$} & {$[0,25]$} & {$[0,17]$} \\
Urbanização & 0,12 & $0,15^{*}$ & 0,02 & 0,01 & 0,02 \\
& {$[0,11]$} & {$[0,08]$} & {$[0,05]$} & {$[0,06]$} & {$[0,06]$} \\
População & $-3,03$ & $-1,78$ & 1,29 & $-3,31^{* *}$ & $-6,35^{* * *}$ \\
& {$[2,52]$} & {$[1,54]$} & {$[1,13]$} & {$[1,30]$} & {$[0,98]$} \\
Constante & $50,92^{* * *}$ & 12,33 & $-16,88^{*}$ & $27,59^{* *}$ & $58,75^{* * *}$ \\
& {$[17,84]$} & {$[19,72]$} & {$[9,14]$} & {$[12,89]$} & {$[8,48]$} \\
$R^{2}$ & 0,003 & 0,002 & 0,002 & 0,002 & 0,008 \\
Observações & 3.345 & 3.345 & 3.345 & 3.345 & 6.690 \\
\hline
\end{tabular}

Fonte: elaboração própria

Nota: erro-padrão robusto entre colchetes; $* * *=$ Significante a $1 \%{ }^{* *}=$ Significante a $5 \%{ }^{*}=$ Significante a $10 \%$ 


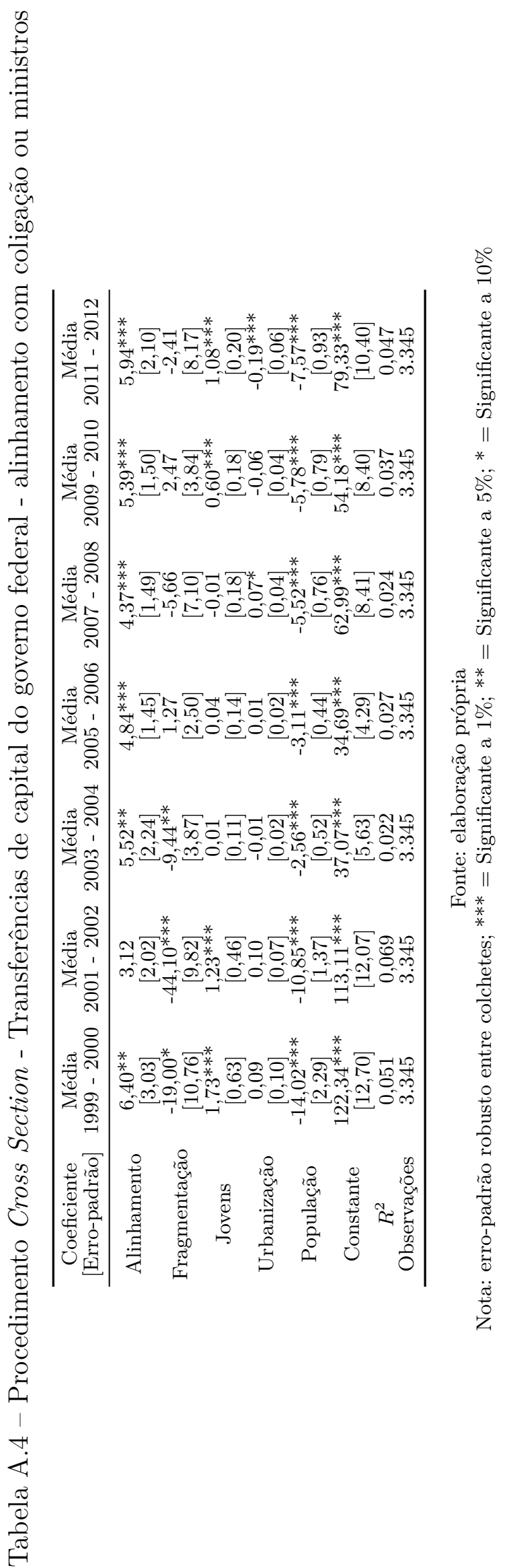




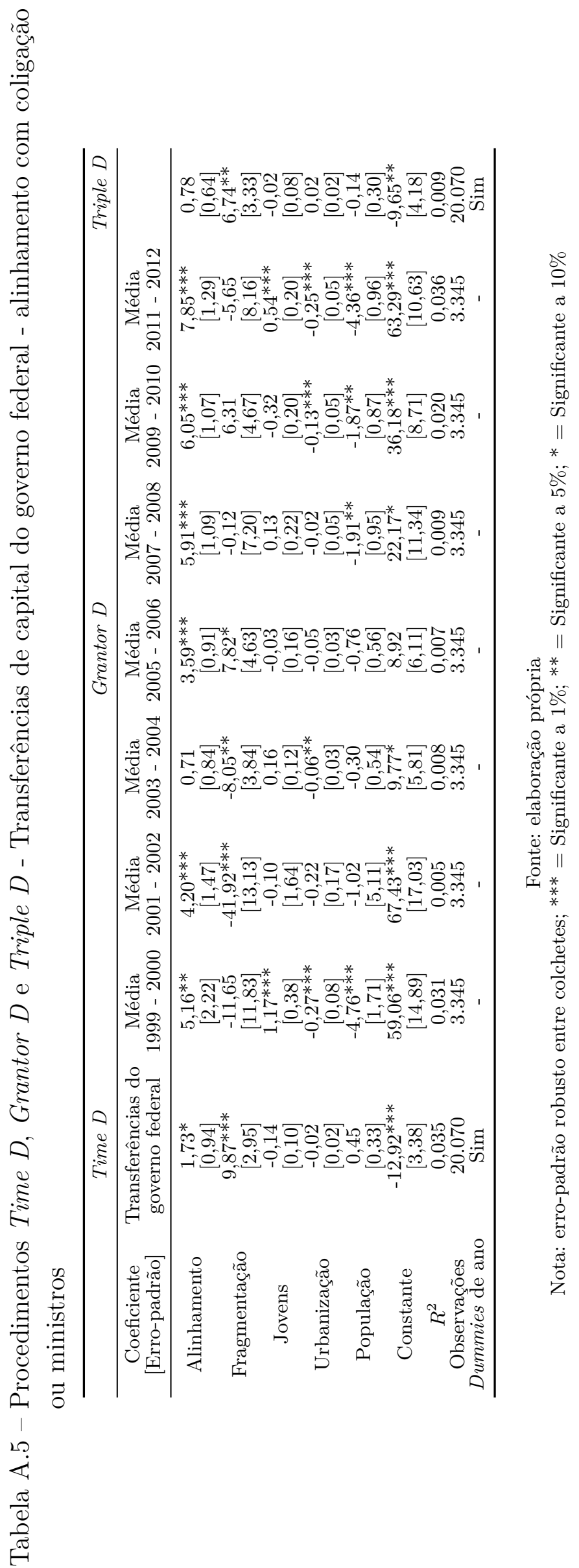




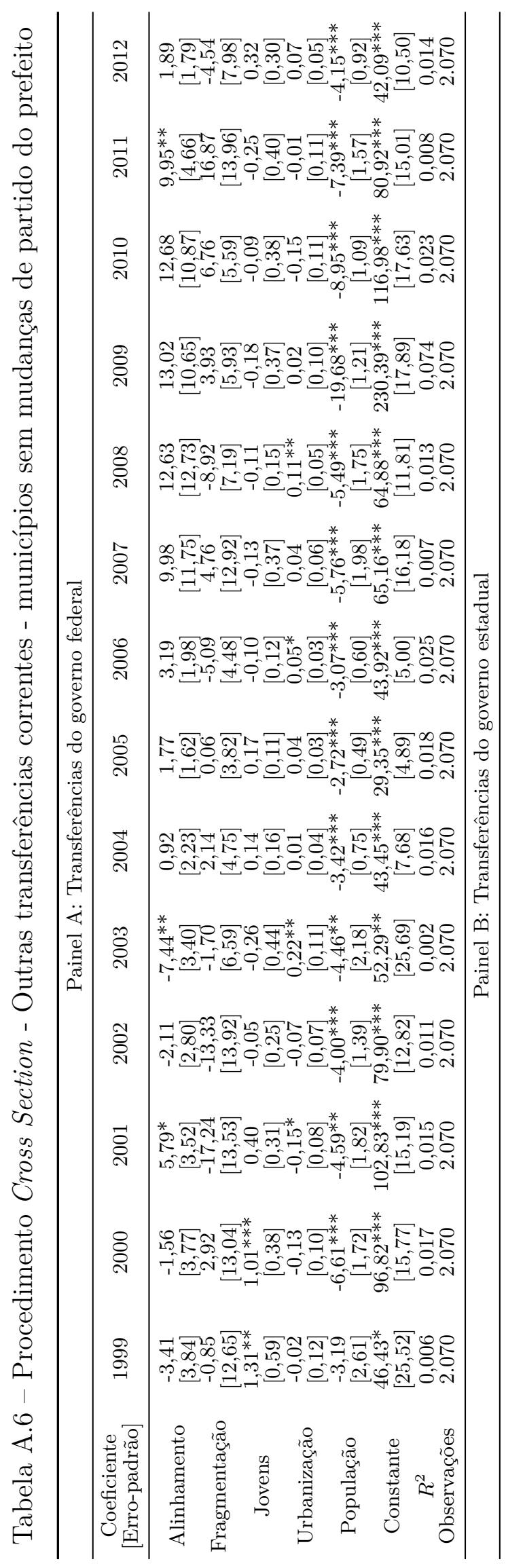

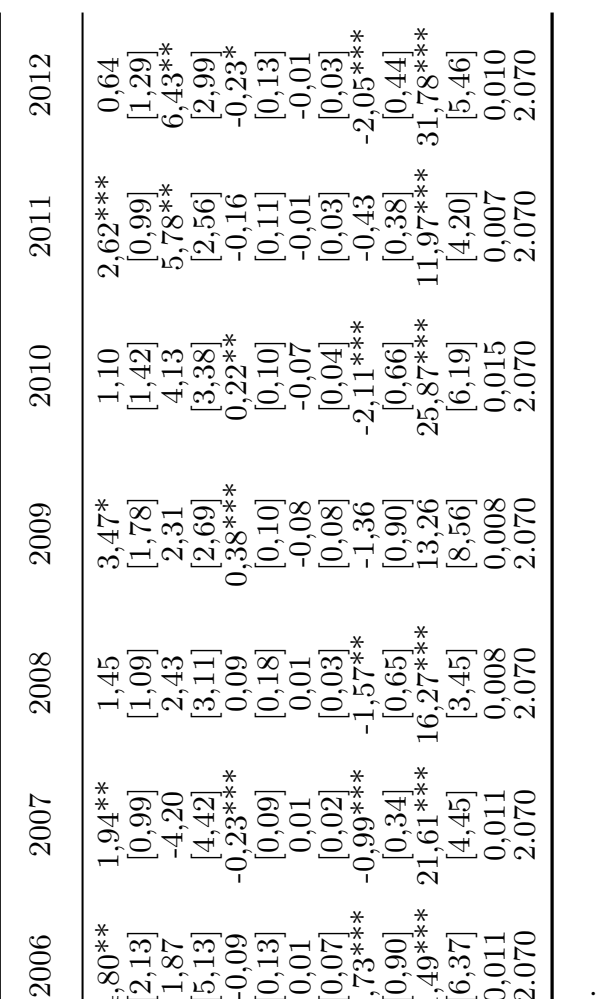

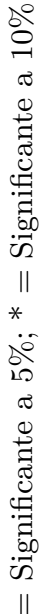

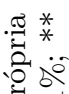

28

邹

A O

范 จ

\% ง

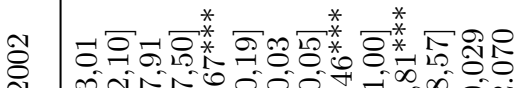

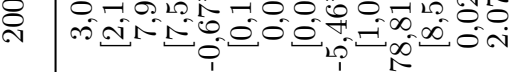

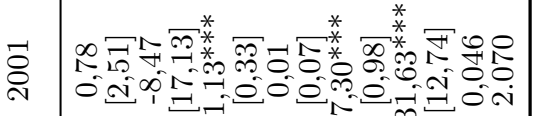

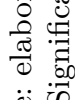

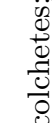

$\stackrel{5}{5}$

0
0
0
0
0
0
0
0
0
0
0
0
$\pi$
0
0
0
0
0
0.0
0
0
7

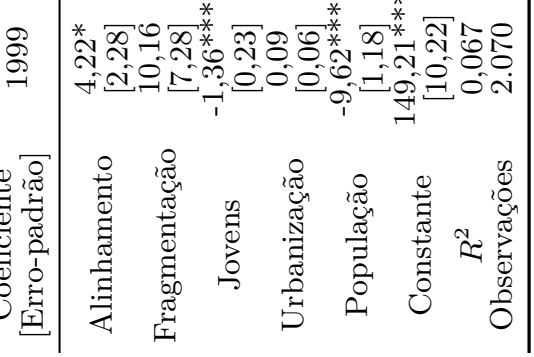


Tabela A.7 - Procedimento Time D - Outras transferências correntes - municípios sem mudanças de partido do prefeito

\begin{tabular}{|c|c|c|c|c|c|}
\hline \multicolumn{6}{|c|}{ Painel A: Transferências do governo federal } \\
\hline $\begin{array}{l}\text { Coeficiente } \\
\text { Erro-padrão }\end{array}$ & $2000-2001$ & $2002-2003$ & 2004-2005 & $2006-2007$ & $2008-2011$ \\
\hline Alinhamento & $\begin{array}{c}0,07 \\
{[2,98]}\end{array}$ & $\begin{array}{l}-3,56 \\
{[4,34]}\end{array}$ & $\begin{array}{l}-0,23 \\
{[1,70]}\end{array}$ & $\begin{array}{c}2,90 \\
{[5,43]}\end{array}$ & $-14,45^{* * *}$ \\
\hline & $\begin{array}{l}{[2,98]} \\
-10,15\end{array}$ & $\begin{array}{l}4,34 \\
11,70\end{array}$ & $\begin{array}{l}{[1,70]} \\
-2,94\end{array}$ & {$\left[\begin{array}{l}{[5,43} \\
9,78\end{array}\right.$} & $\begin{array}{l}{[3,40]} \\
5,60\end{array}$ \\
\hline Fragmentação & {$[12,77]$} & {$[14,95]$} & {$[4,94]$} & {$[13,38]$} & {$[7,56]$} \\
\hline Joren & $-0,47$ & $-0,20$ & 0,06 & $-0,02$ & 0,22 \\
\hline Joven & {$[0,39]$} & {$[0,51]$} & {$[0,17]$} & {$[0,38]$} & {$[0,22]$} \\
\hline & 0,00 & $0,29^{* *}$ & 0,05 & $-0,01$ & $-0,08$ \\
\hline Urbanização & {$[0,10]$} & {$[0,11]$} & {$[0,04]$} & {$[0,05]$} & {$[0,07]$} \\
\hline Populacão & 1,45 & $-0,58$ & 0,69 & $-2,47$ & $-5,07 * * *$ \\
\hline & {$[1,86]$} & {$[2,03]$} & {$[0,64]$} & {$[1,76]$} & {$[1,27]$} \\
\hline Constante & 3,09 & $-27,39$ & $-14,64^{*}$ & 20,08 & $59,44^{* * *}$ \\
\hline$R^{2}$ & {$[17,11]$} & {$[27,02]$} & {$[7,79]$} & {$[15,04]$} & {$[10,92]$} \\
\hline Observações & $\begin{array}{l}0,001 \\
2.070\end{array}$ & & & $\begin{array}{l}0,001 \\
2.070\end{array}$ & \\
\hline \multicolumn{6}{|c|}{ Painel B: Transferências do governo estadual } \\
\hline $\begin{array}{l}\text { Coeficiente } \\
\text { Erro-padrão }\end{array}$ & $2000-2001$ & $2002-2003$ & $2004-2005$ & $2006-2007$ & $2008-2011$ \\
\hline & 2,94 & 0,58 & $-0,30$ & 0,93 & $-1,23$ \\
\hline Alinhamento & {$[2,41]$} & {$[1,44]$} & {$[1,89]$} & {$[0,73]$} & {$[1,33]$} \\
\hline Fraomentacão & $-7,17$ & $-4,76$ & $-4,40$ & $-5,85$ & 0,87 \\
\hline & {$[10,46]$} & {$[7,11]$} & {$[5,64]$} & {$[6,52]$} & {$[2,18]$} \\
\hline & $0,80^{* *}$ & $0,37^{* *}$ & $0,34^{* *}$ & $-0,14$ & $-0,08$ \\
\hline & {$[0,34]$} & & {$[0,16]$} & {$[0,14]$} & \\
\hline Urbanizacão & $-0,08$ & 0,05 & 0,06 & $-0,01$ & $-0,02$ \\
\hline & {$[0,06]$} & {$[0,05]$} & {$[0,05]$} & {$[0,07]$} & {$[0,04]$} \\
\hline População & 3,35 *** & $2,68^{* * * *}$ & $-1,09$ & $1,75^{*}$ & $1,05 * * *$ \\
\hline & $-51,70^{* * *}$ & $-44,27^{* * * *}$ & $\begin{array}{l}{[1,22]} \\
-0,89\end{array}$ & $\begin{array}{l}{[0,94]} \\
-11,20\end{array}$ & $\begin{array}{l}{[0,40]} \\
-7,06^{* *}\end{array}$ \\
\hline Constante & {$[13,22]$} & {$[7,81]$} & {$[7,07]$} & (7) & {$[3,59]$} \\
\hline$R^{2}$ & & & & & \\
\hline Observações & 2.070 & 2.070 & 2.070 & 2.070 & 4.140 \\
\hline
\end{tabular}

Fonte: elaboração própria

Nota: erro-padrão robusto entre colchetes; $* * *=$ Significante a $1 \% ; * *=$ Significante a $5 \%{ }^{*}=$ Significante a $10 \%$ 


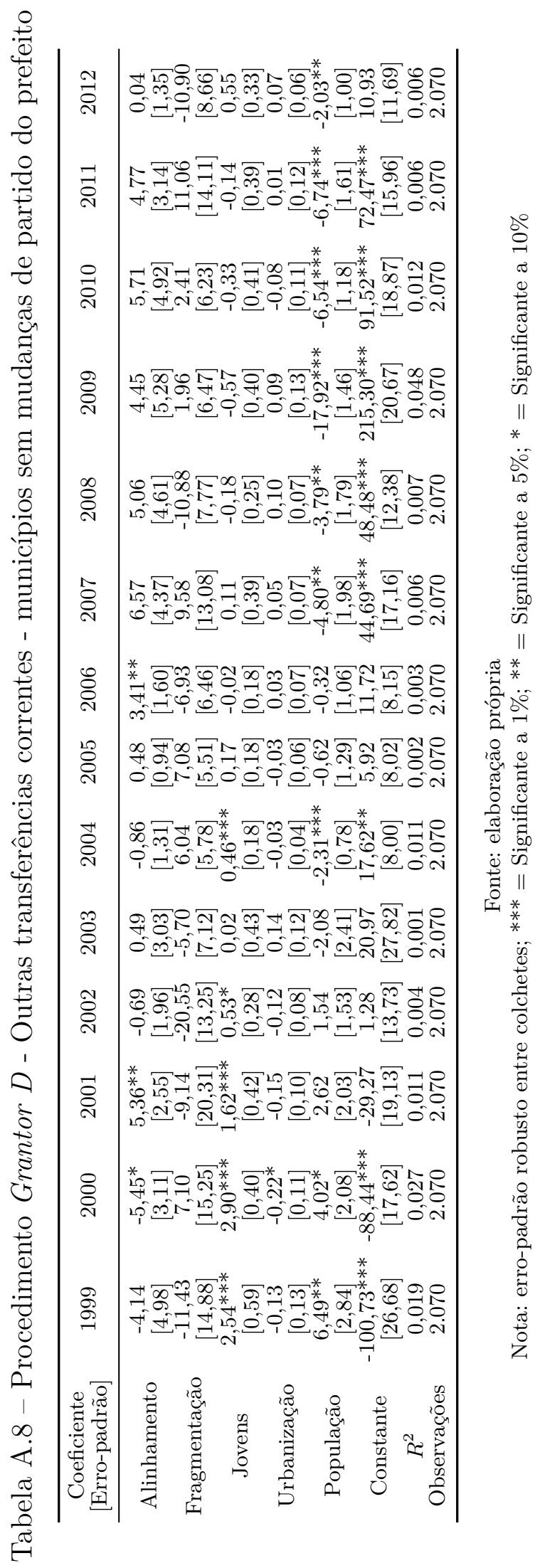


Tabela A.9 - Procedimento Triple D - Outras transferências correntes - municípios sem mudanças de partido do prefeito

\begin{tabular}{cccccc}
\hline $\begin{array}{c}\text { Coeficiente } \\
\text { [Erro-padrão] }\end{array}$ & $2000-2001$ & $2002-2003$ & $2004-2005$ & $2006-2007$ & $2008-2011$ \\
\hline Alinhamento & $-2,94$ & $-0,89$ & $-1,10$ & 1,68 & $-1,08$ \\
& {$[3,31]$} & {$[1,86]$} & {$[1,26]$} & {$[1,76]$} & {$[2,28]$} \\
Fragmentação & $-3,40$ & 15,12 & 1,47 & 15,70 & 5,00 \\
& {$[14,93]$} & {$[14,37]$} & {$[7,55]$} & {$[14,28]$} & {$[7,80]$} \\
Jovens & $-1,27^{* *}$ & $-0,50$ & $-0,27$ & 0,12 & $0,41^{*}$ \\
& {$[0,49]$} & {$[0,49]$} & {$[0,22]$} & {$[0,41]$} & {$[0,22]$} \\
Urbanização & 0,08 & $0,25^{* *}$ & $-0,01$ & 0,01 & $-0,05$ \\
& {$[0,11]$} & {$[0,12]$} & {$[0,06]$} & {$[0,10]$} & {$[0,08]$} \\
População & $-1,86$ & $-3,38$ & 1,78 & $-4,22^{* *}$ & $-6,09^{* * *}$ \\
& {$[2,15]$} & {$[2,20]$} & {$[1,36]$} & {$[2,00]$} & {$[1,33]$} \\
Constante & $54,57^{* * *}$ & 16,98 & $-13,95$ & $31,25^{*}$ & $60,42^{* * *}$ \\
$R^{2}$ & {$[20,06]$} & {$[27,54]$} & {$[10,26]$} & {$[17,04]$} & {$[10,99]$} \\
Observações & 0,005 & 0,002 & 0,003 & 0,003 & 0,007 \\
& 2.070 & 2.070 & 2.070 & 2.070 & 4.140 \\
\hline
\end{tabular}

Fonte: elaboração própria

Nota: erro-padrão robusto entre colchetes; $* * *=$ Significante a $1 \%{ }^{* *}=$ Significante a $5 \%{ }^{*}=$ Significante a $10 \%$ 


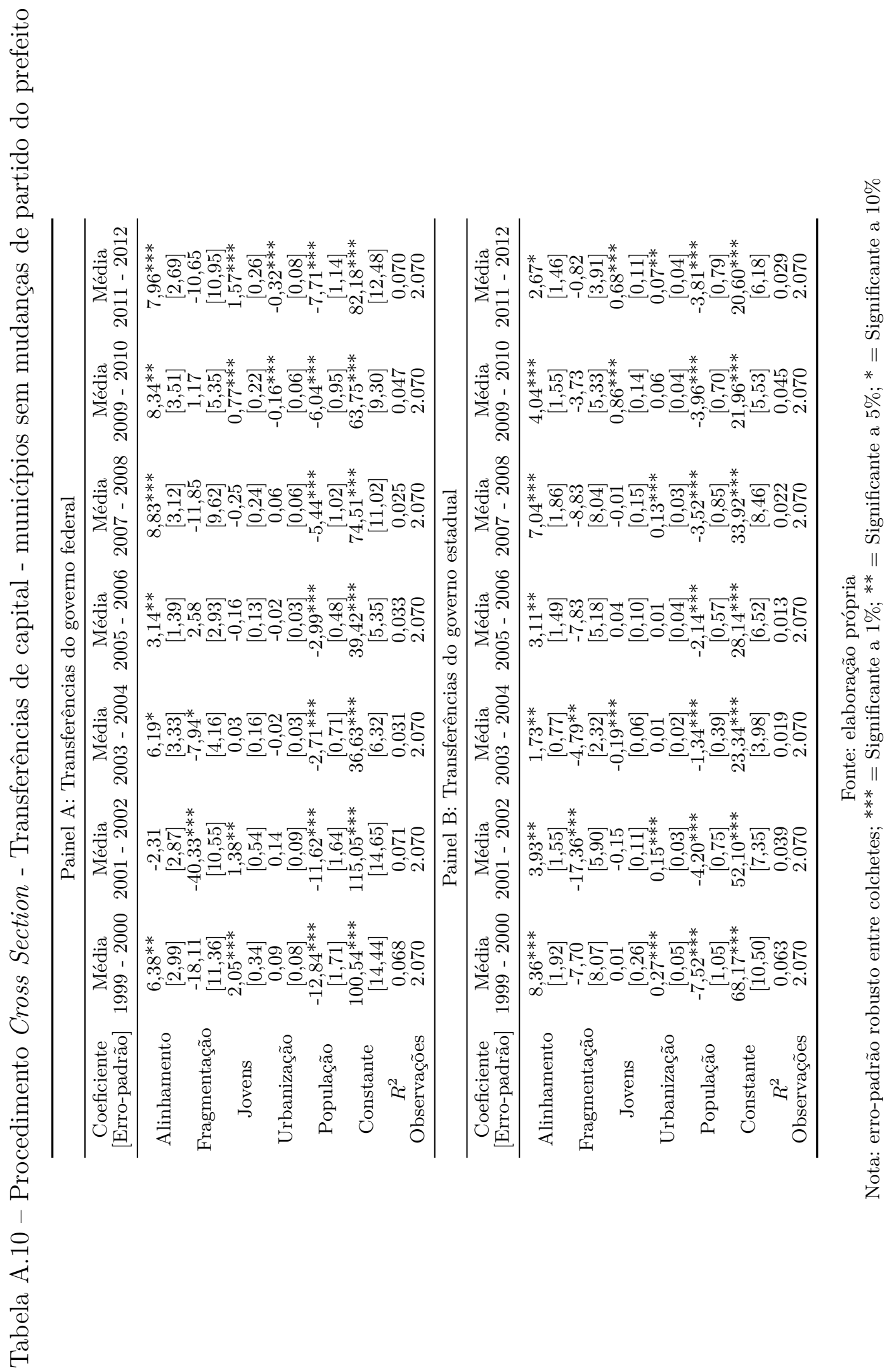




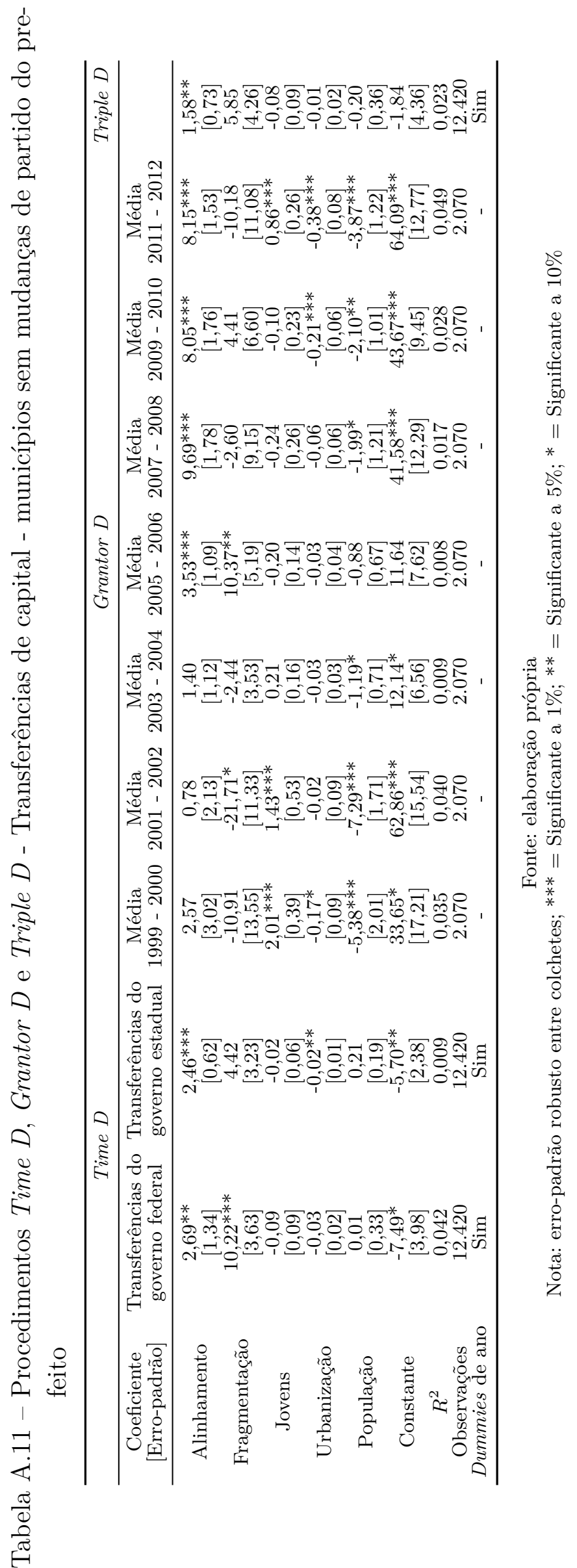




\section{Apêndice B: Tabelas e figuras complementares do Capítulo 3}

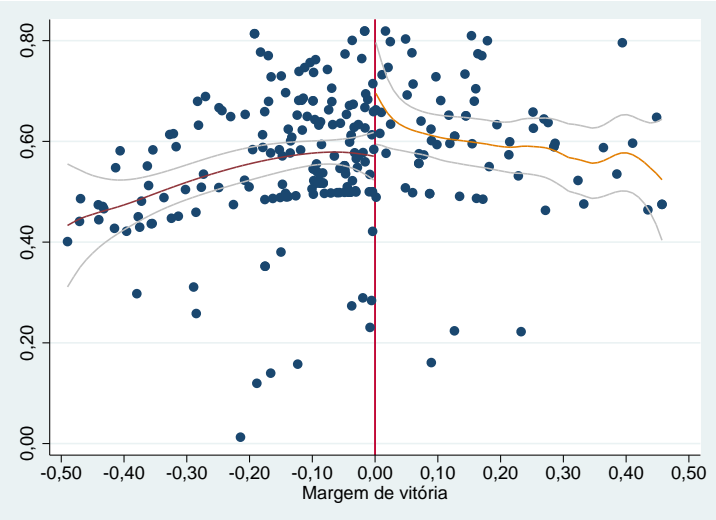

(a) Alinhamento com coligação

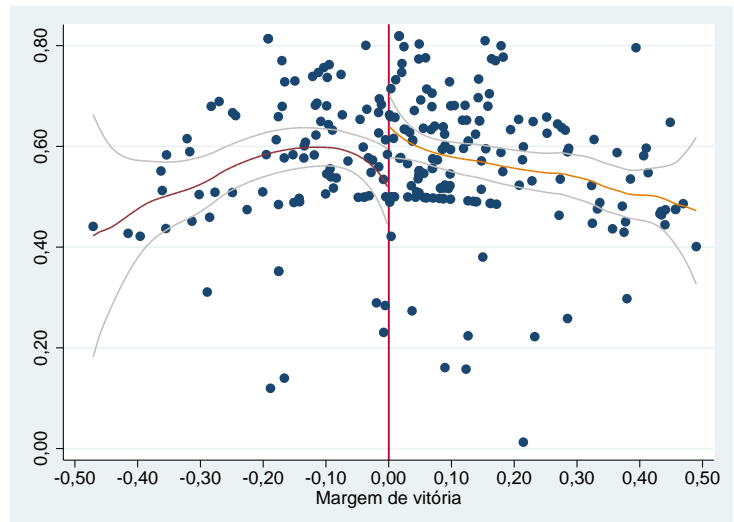

(b) Alinhamento com ministérios

Figura B.1 - Fragmentação de votos - municípios

Fonte: elaboração própria

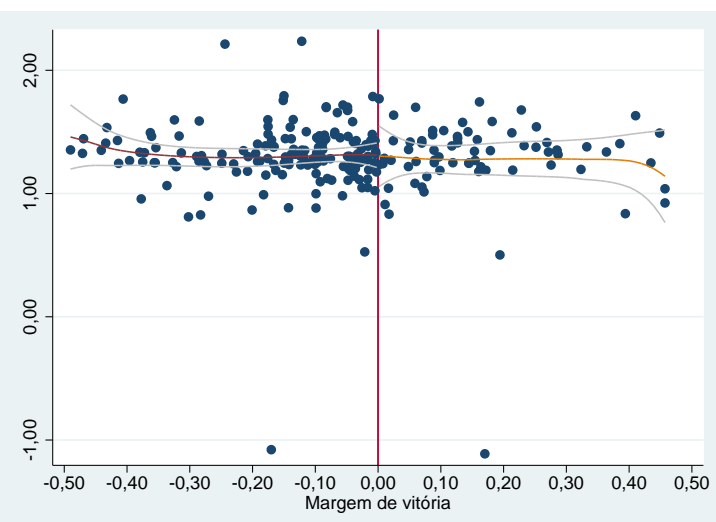

(a) Alinhamento com coligação

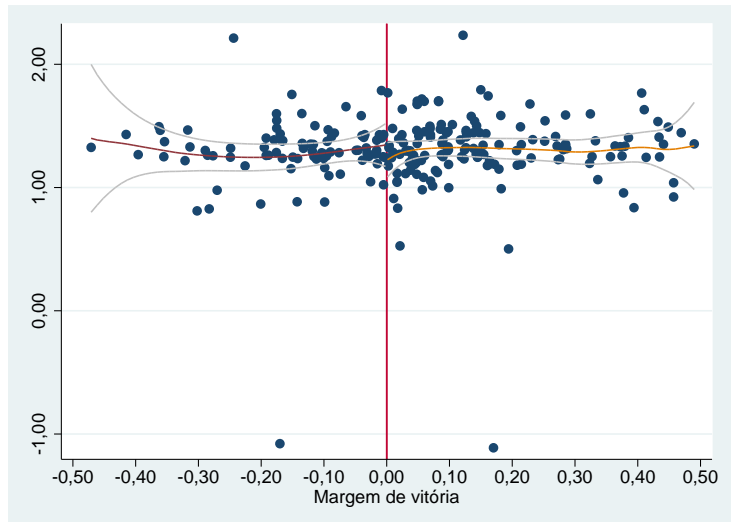

(b) Alinhamento com ministérios

Figura B.2 - Distância da razão DCL / RCL - municípios

Fonte: elaboração própria 


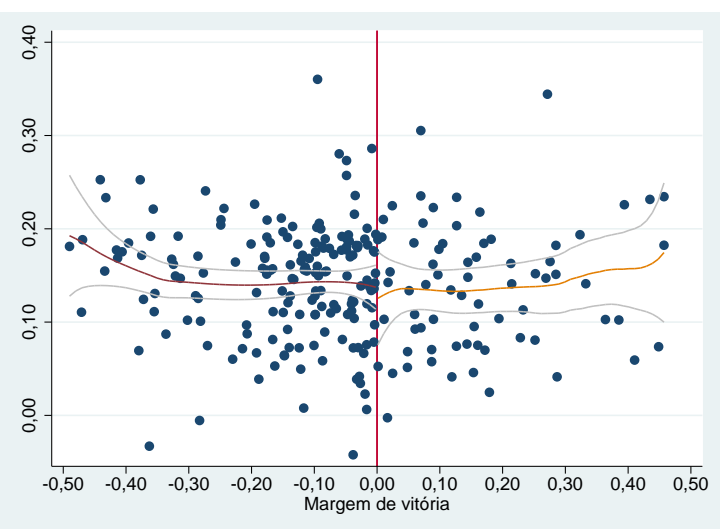

(a) Alinhamento com coligação

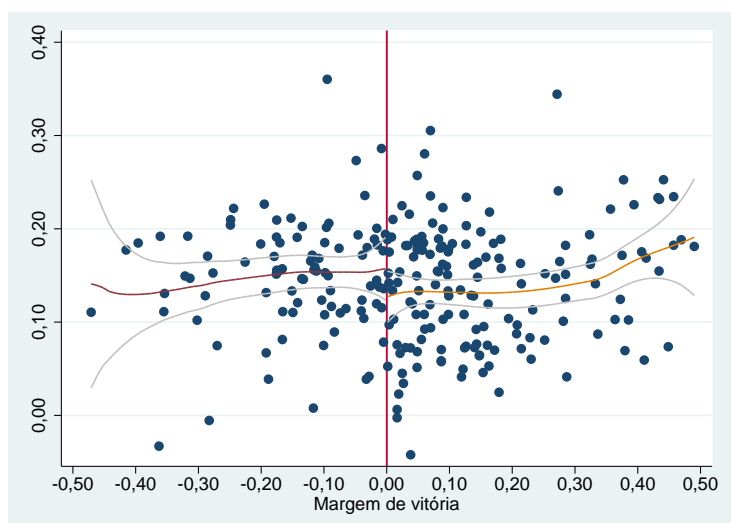

(b) Alinhamento com ministérios

Figura B.3 - Distância da razão Pessoal / RCL - municípios

Fonte: elaboração própria

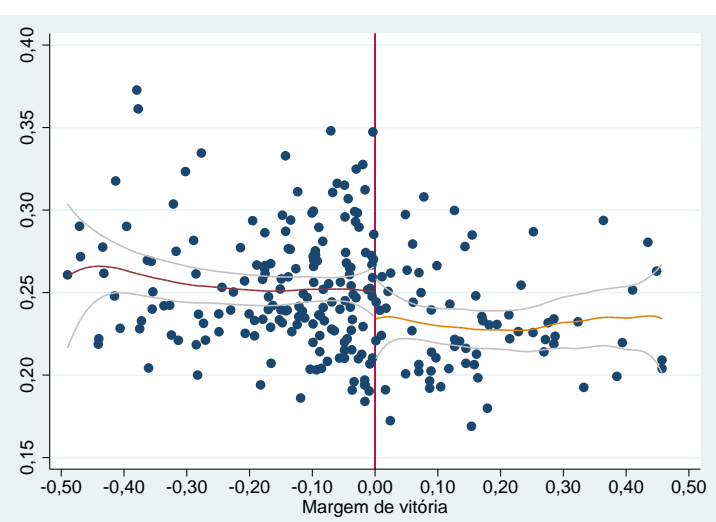

(a) Alinhamento com coligação

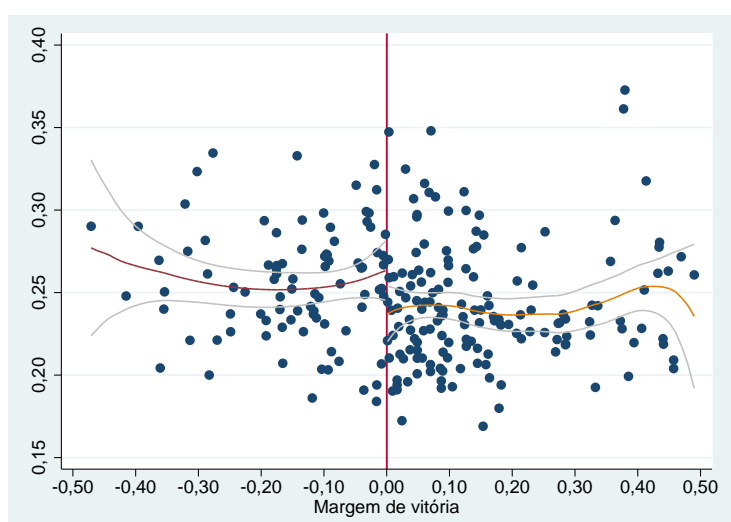

(b) Alinhamento com ministérios

Figura B.4 - Percentagem de jovens - municípios

Fonte: elaboração própria

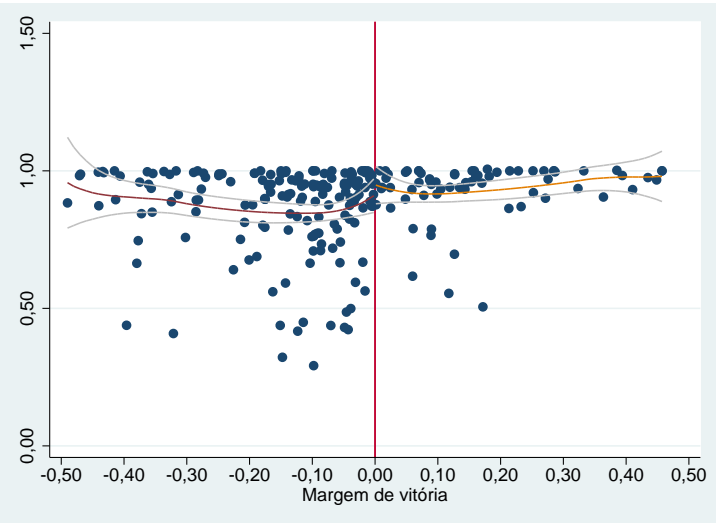

(a) Alinhamento com coligação

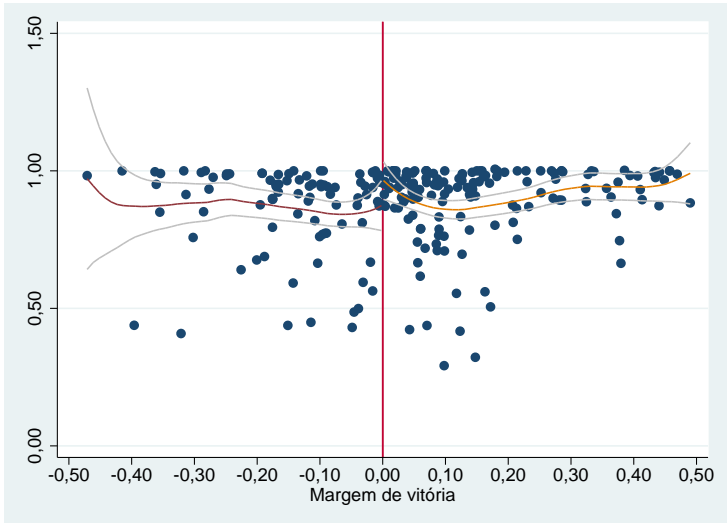

(b) Alinhamento com ministérios

Figura B.5 - Percentagem urbana - municípios

Fonte: elaboração própria 


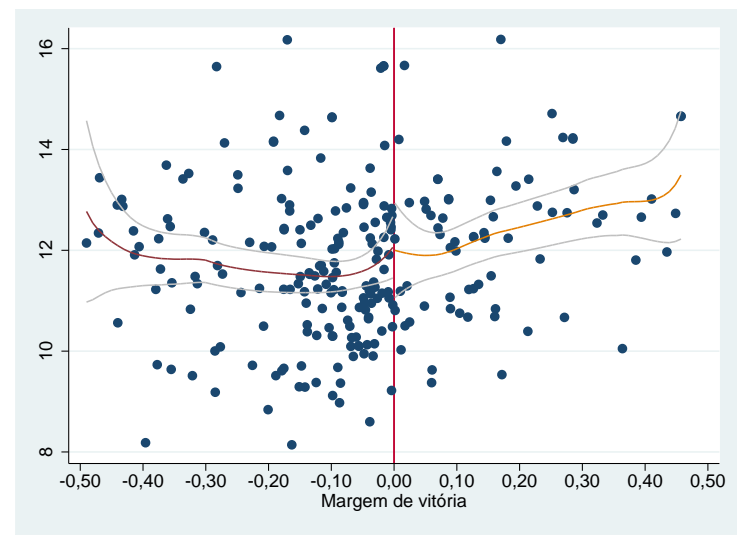

(a) Alinhamento com coligação

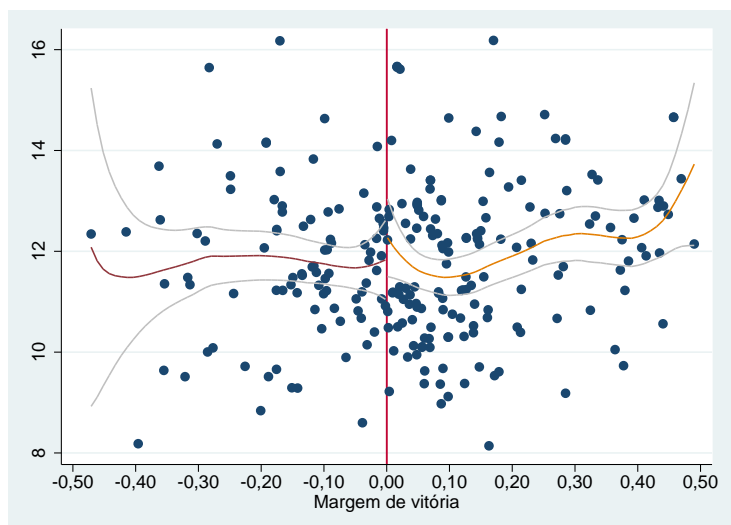

(b) Alinhamento com ministérios

Figura B.6 - População (ln) - municípios

Fonte: elaboração própria

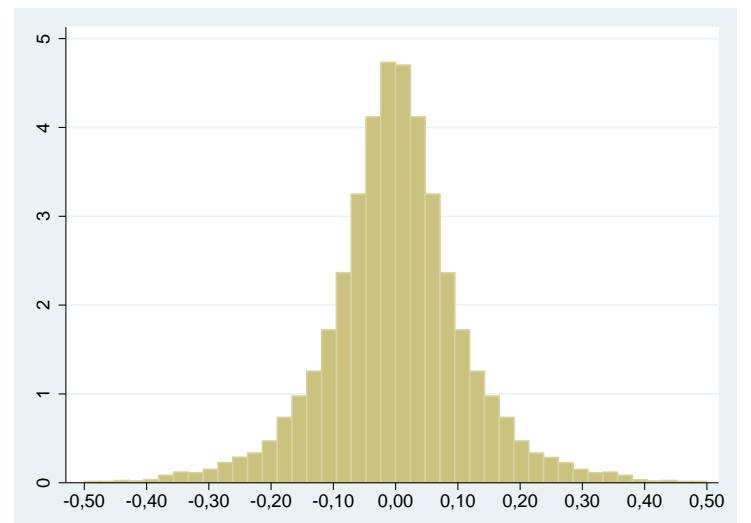

(a) Histograma da proporção de votos - municípios

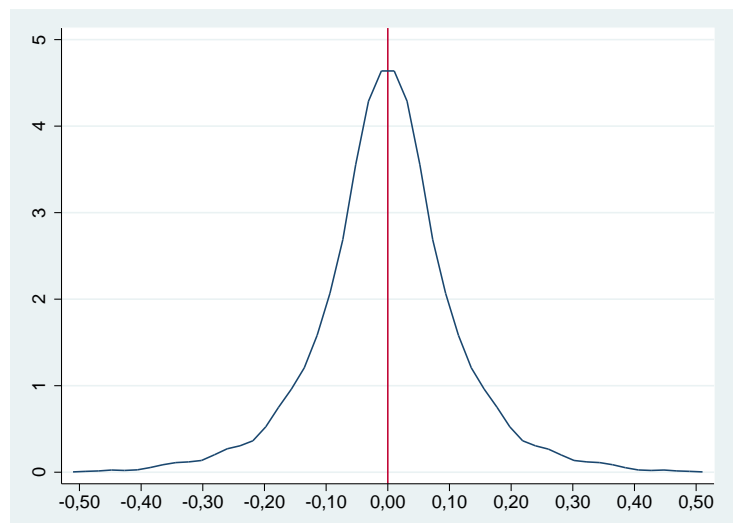

(b) Densidade da proporção de votos - municípios

Figura B.7 - Testes de densidade - municípios

Fonte: elaboração própria

Nota: valores positivos (à direita do threshold) se referem à proporção recebida de votos por candidatos eleitos e valores negativos (à esquerda do threshold) se referem à proporção recebida de votos pelo segundo melhor colocado, ambos normalizados em torno da margem igual a zero; dados referentes às eleições de 2000, 2004 e 2008. 
Tabela B.1 - Testes não paramétricos de descontinuidade das variáveis de controle municípios

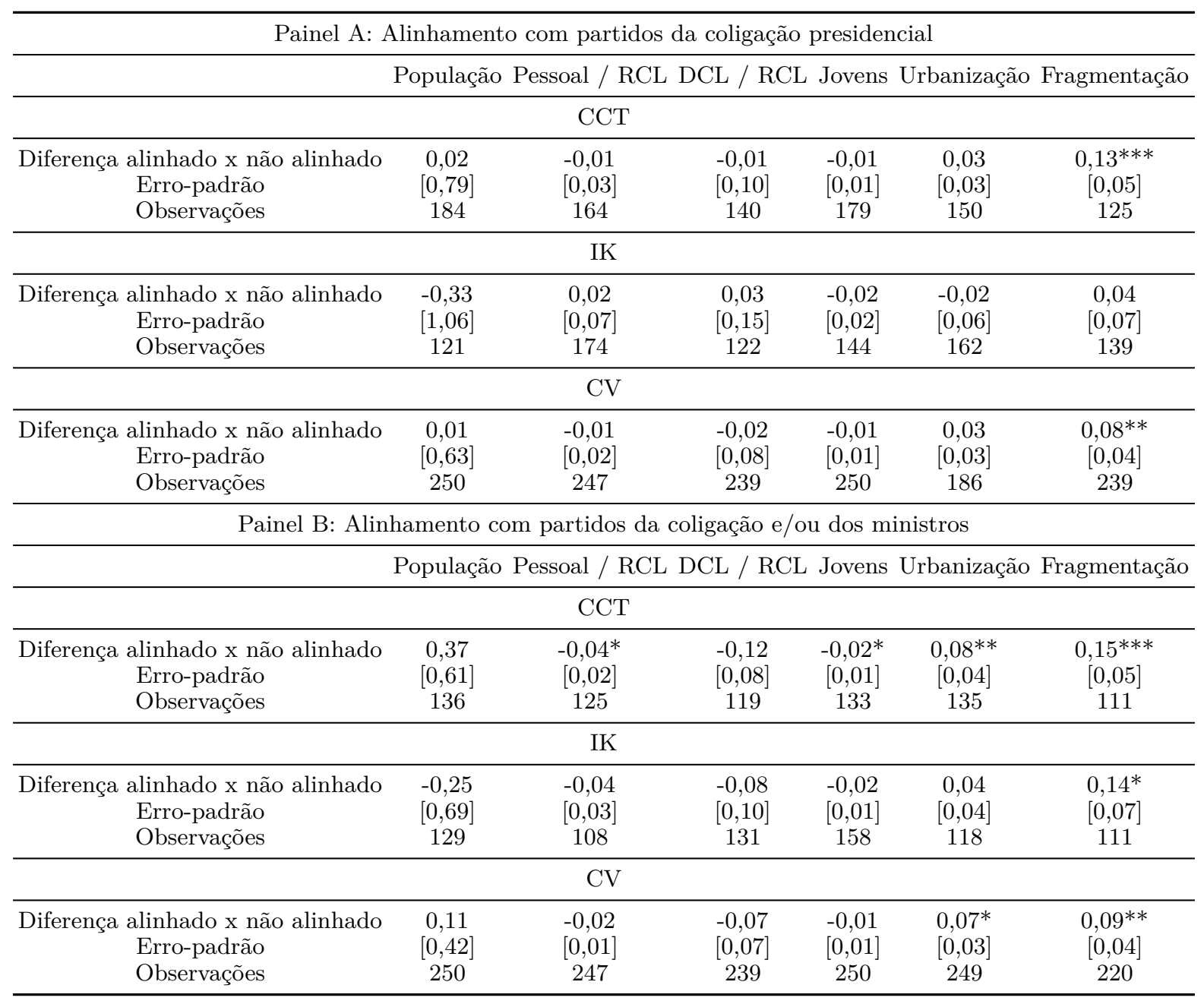

Fonte: elaboração própria

Nota: diferença se refere ao valor da diferença da variável entre unidades alinhadas e não alinhadas em torno da margem de vitória igual a zero; CCT, IK e CV se referem aos métodos de definição da banda (bandwidth) propostos por Calonico, Cattaneo e Titiunik (2014), Imbens e Kalyanaraman (2012) e Ludwig e Miller (2007), respectivamente; ${ }^{* * *}=$ Significante a $1 \%{ }^{* *}=$ Significante a $5 \%$; ${ }^{*}$ Significante a $10 \%$. 
Tabela B.2 - Testes não paramétricos adicionais de descontinuidade - municípios

\begin{tabular}{|c|c|c|c|c|c|}
\hline \multicolumn{6}{|c|}{ Painel A: Alinhamento com partidos da coligação presidencial } \\
\hline & \multicolumn{2}{|c|}{ Total } & \multicolumn{2}{|c|}{ Reembolsável } & \multirow[b]{2}{*}{$\begin{array}{c}\text { Prazo de } \\
\text { carência }\end{array}$} \\
\hline & $\begin{array}{c}\text { Valor do } \\
\text { financiamento }\end{array}$ & $\begin{array}{c}\text { Valor do } \\
\text { financiamento }\end{array}$ & $\begin{array}{c}\text { Taxa de } \\
\text { juros }\end{array}$ & $\begin{array}{c}\text { Prazo de } \\
\text { amortização }\end{array}$ & \\
\hline \multicolumn{6}{|c|}{$\mathrm{CCT}$} \\
\hline Diferença alinhado x não alinhado & 0,35 & $-0,25$ & 0,01 & $-13,65^{* *}$ & 1,41 \\
\hline Erro-padrão & {$[0,33]$} & {$[0,30]$} & {$[0,21]$} & {$[6,14]$} & {$[2,21]$} \\
\hline Observações & 140 & 137 & 129 & 135 & 109 \\
\hline \multicolumn{6}{|c|}{ IK } \\
\hline Diferença alinhado x não alinhado & 1,01 & 0,60 & 0,75 & $-11,59$ & 1,76 \\
\hline Erro-padrão & {$[0,63]$} & {$[0,91]$} & {$[0,90]$} & {$[7,26]$} & {$[2,69]$} \\
\hline Observações & 153 & 169 & 178 & 122 & 102 \\
\hline \multicolumn{6}{|c|}{$\mathrm{CV}$} \\
\hline Diferença alinhado x não alinhado & 0,28 & $-0,17$ & 0,01 & $-14,98$ & $-1,11$ \\
\hline Erro-padrão & {$[0,26]$} & {$[0,24]$} & {$[0,15]$} & {$[5,33]$} & {$[1,52]$} \\
\hline Observações & 247 & 220 & 220 & 200 & 213 \\
\hline \multicolumn{6}{|c|}{ Painel B: Alinhamento com partidos da coligação e/ou dos ministros } \\
\hline \multicolumn{3}{|c|}{ Total } & \multicolumn{2}{|c|}{ Reembolsável } & \\
\hline & $\begin{array}{c}\text { Valor do } \\
\text { financiamento }\end{array}$ & $\begin{array}{c}\text { Valor do } \\
\text { financiamento }\end{array}$ & $\begin{array}{l}\text { Taxa de } \\
\text { juros }\end{array}$ & $\begin{array}{c}\text { Prazo de } \\
\text { amortização }\end{array}$ & $\begin{array}{l}\text { Prazo de } \\
\text { carência }\end{array}$ \\
\hline \multicolumn{6}{|c|}{$\mathrm{CCT}$} \\
\hline Diferença alinhado x não alinhado & $-0,36$ & $-0,36$ & 0,02 & $-6,54$ & 2,60 \\
\hline Erro-padrão & {$[0,38]$} & {$[0,35]$} & {$[0,19]$} & {$[7,37]$} & {$[1,97]$} \\
\hline Observações & 127 & 116 & 151 & 124 & 139 \\
\hline \multicolumn{6}{|c|}{ IK } \\
\hline Diferença alinhado x não alinhado & 0,06 & 0,11 & $-0,12$ & $-3,60$ & 1,71 \\
\hline Erro-padrão & {$[0,46]$} & {$[0,40]$} & {$[0,33]$} & {$[8,24]$} & {$[2,41]$} \\
\hline Observações & 134 & 119 & 116 & 114 & 122 \\
\hline \multicolumn{6}{|c|}{$\mathrm{CV}$} \\
\hline Diferença alinhado x não alinhado & $-0,09$ & 0,06 & $-0,07$ & 0,49 & 1,98 \\
\hline Erro-padrão & {$[0,30]$} & {$[0,29]$} & {$[0,16]$} & {$[5,31]$} & {$[1,74]$} \\
\hline Observações & 247 & 213 & 220 & 220 & 207 \\
\hline
\end{tabular}

Fonte: elaboração própria

Nota: diferença se refere ao valor da diferença da variável entre unidades alinhadas e não alinhadas em torno da margem de vitória igual a zero; CCT, IK e CV se referem aos métodos de definição da banda (bandwidth) propostos por Calonico, Cattaneo e Titiunik (2014), Imbens e Kalyanaraman (2012) e Ludwig e Miller (2007), respectivamente; ${ }^{* * *}=$ Significante a $1 \% ;{ }^{* *}=$ Significante a $5 \%{ }^{*}=$ Significante a $10 \%$. 


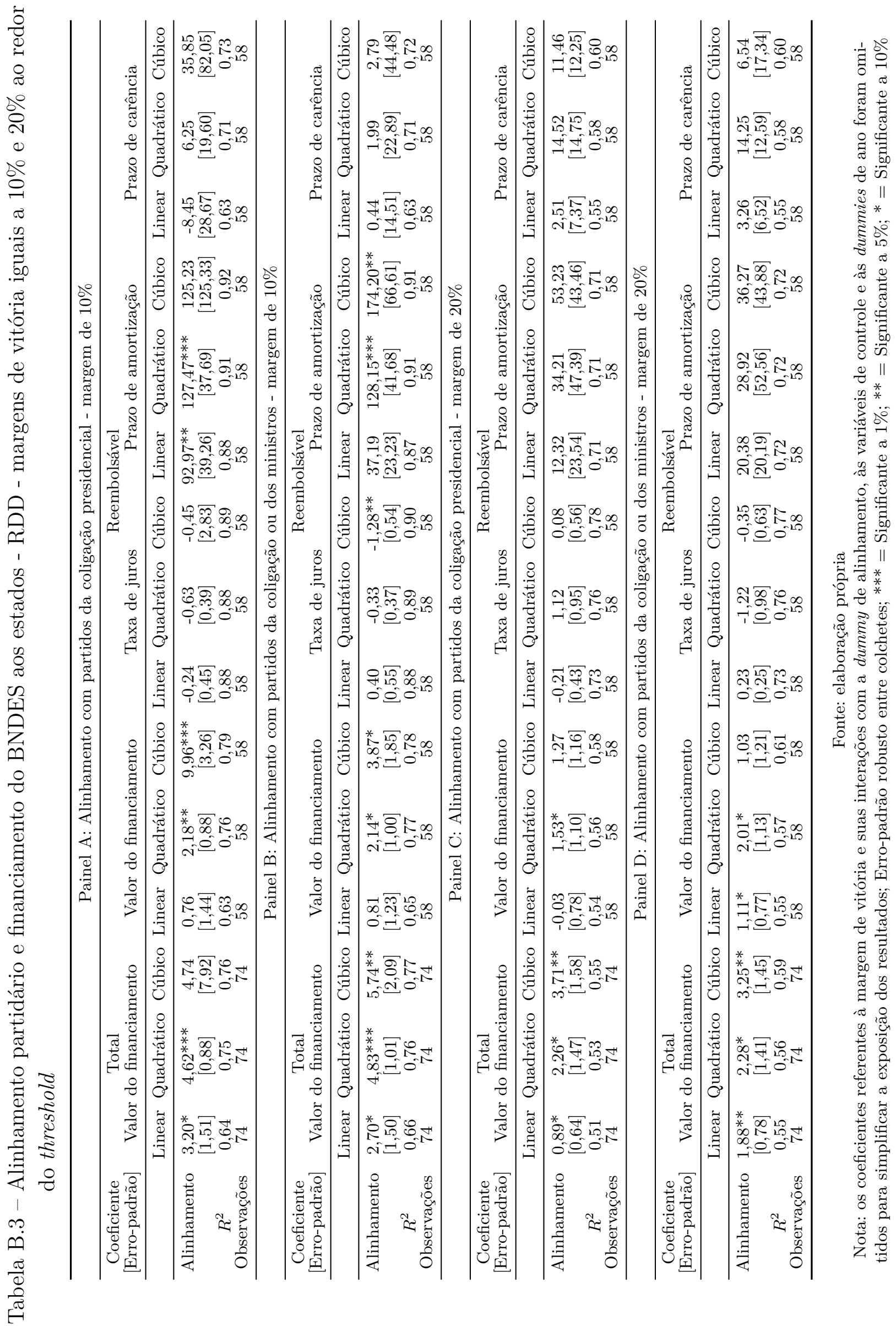




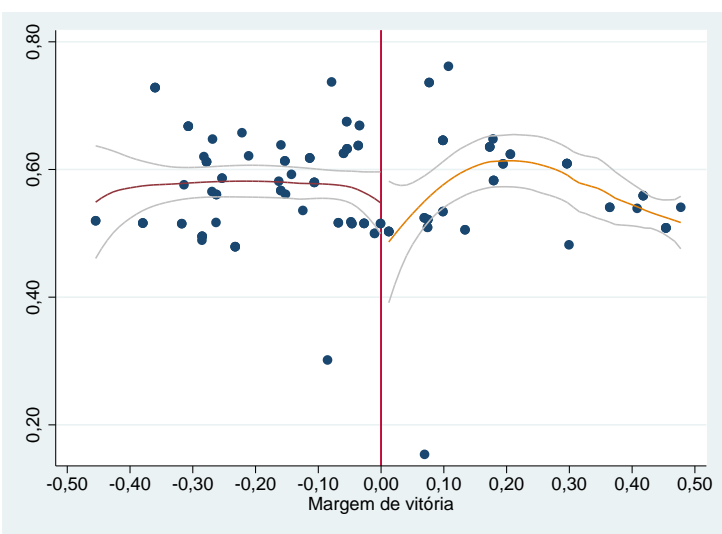

(a) Alinhamento com coligação

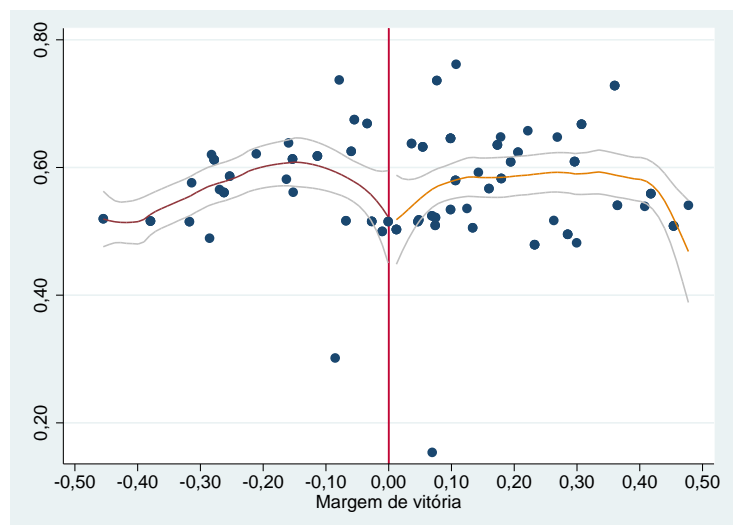

(b) Alinhamento com ministérios

Figura B.8 - Fragmentação de votos - estados

Fonte: elaboração própria

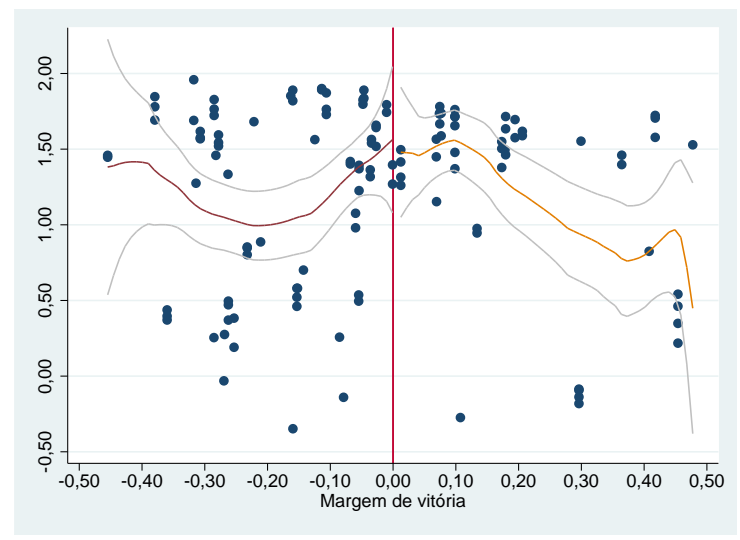

(a) Alinhamento com coligação

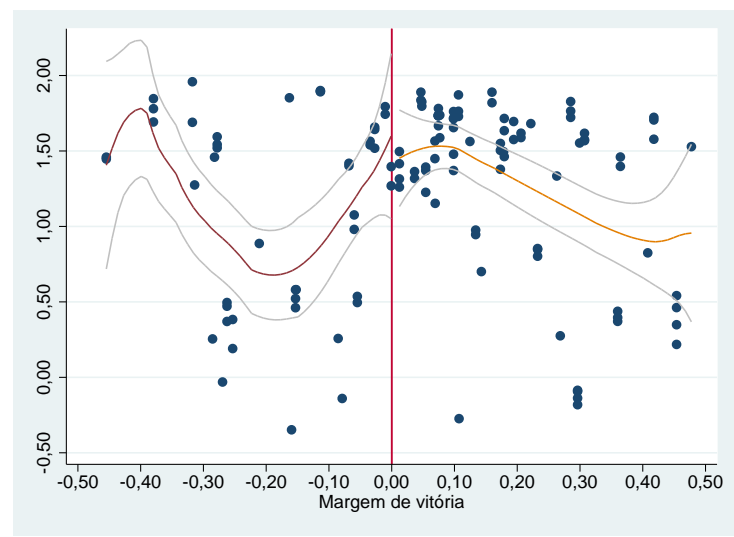

(b) Alinhamento com ministérios

Figura B.9 - Distância da razão DCL / RCL - estados

Fonte: elaboração própria

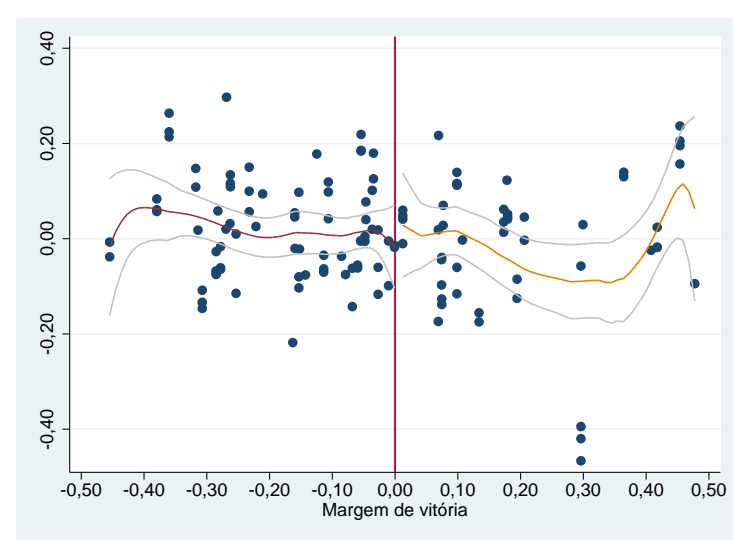

(a) Alinhamento com coligação

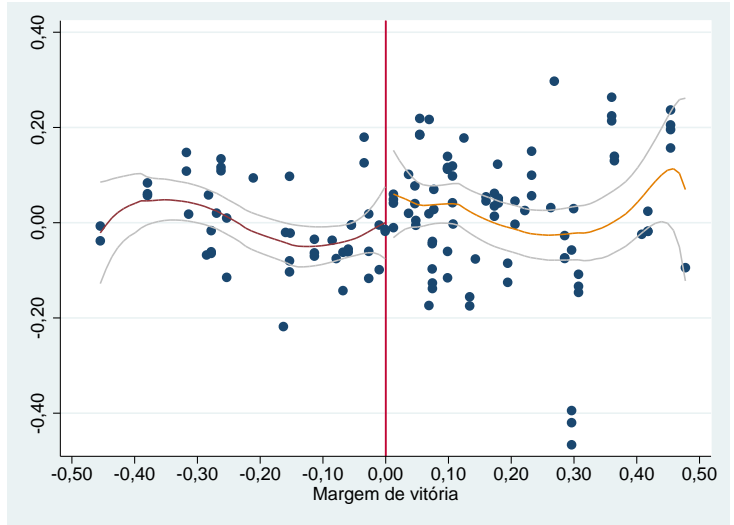

(b) Alinhamento com ministérios

Figura B.10 - Distância da razão Pessoal / RCL - estados 


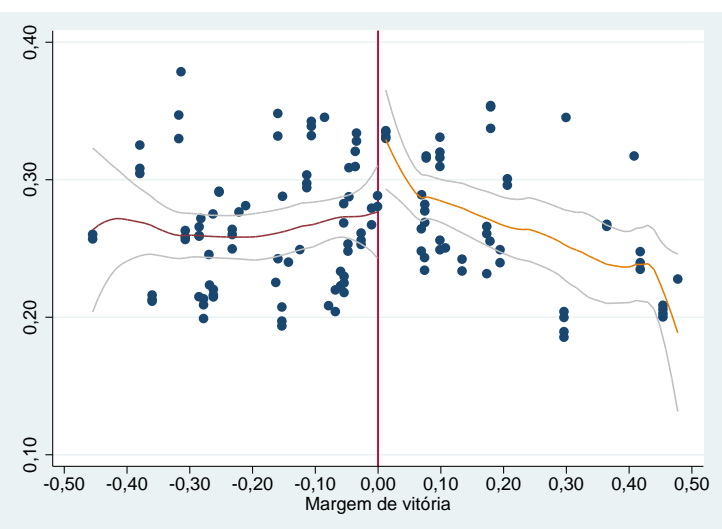

(a) Alinhamento com coligação

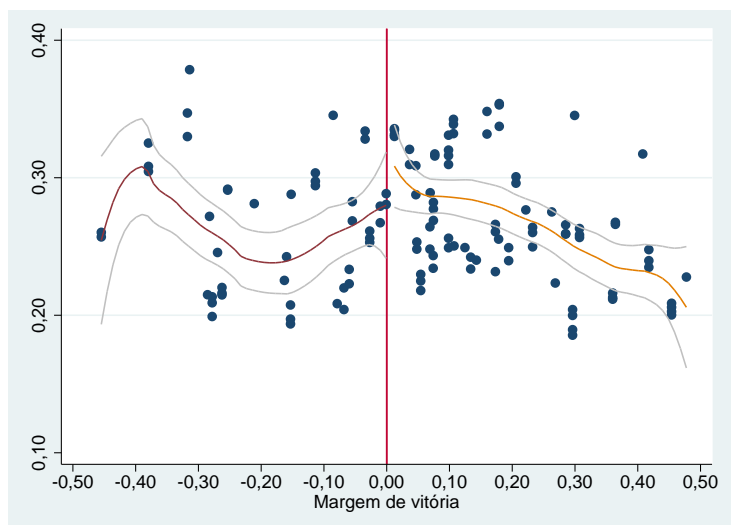

(b) Alinhamento com ministérios

Figura B.11 - Percentagem de jovens - estados

Fonte: elaboração própria

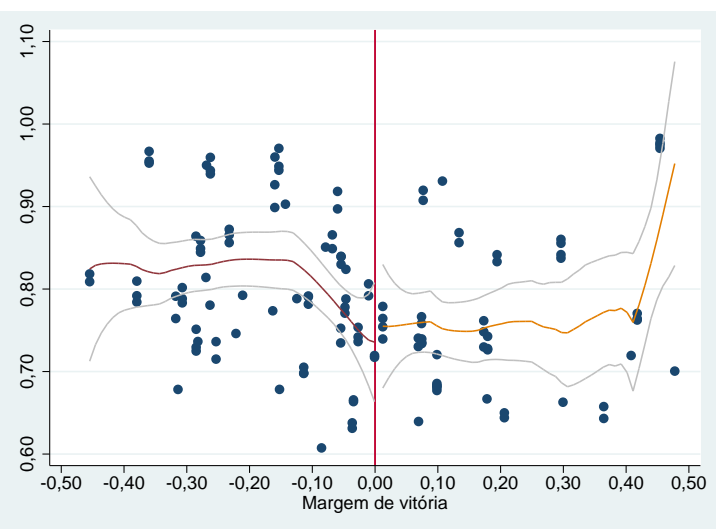

(a) Alinhamento com coligação

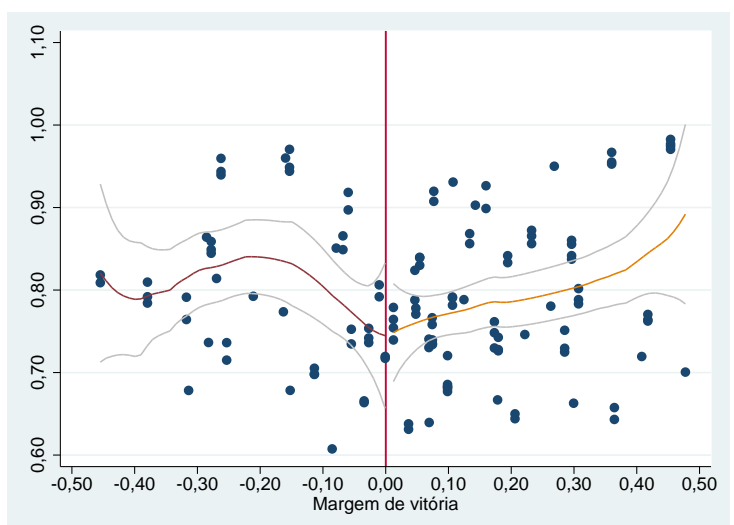

(b) Alinhamento com ministérios

Figura B.12 - Percentagem urbana - estados

Fonte: elaboração própria

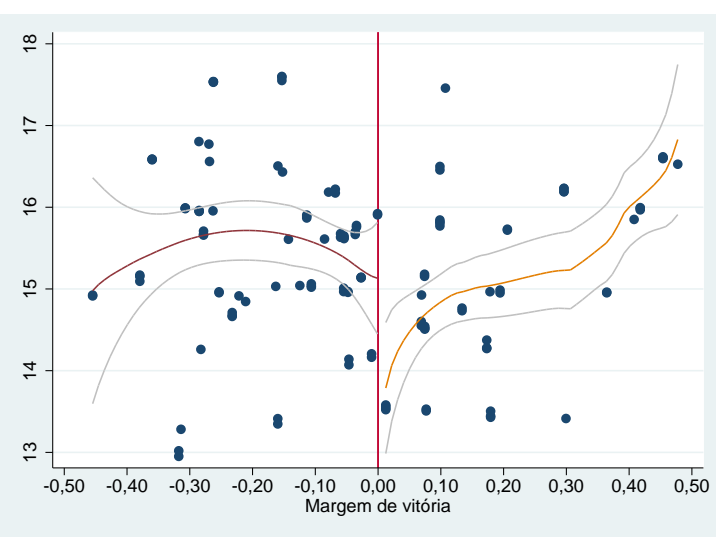

(a) Alinhamento com coligação

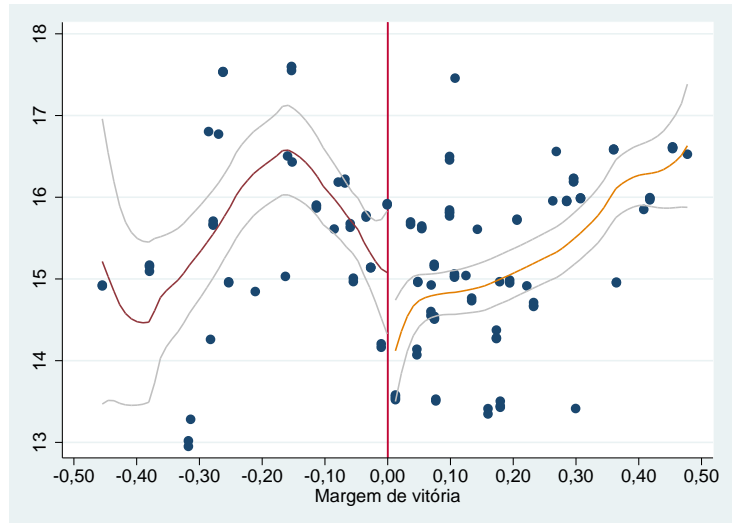

(b) Alinhamento com ministérios

Figura B.13 - População (ln) - estados 
Tabela B.4 - Testes não paramétricos de descontinuidade das variáveis de controle estados

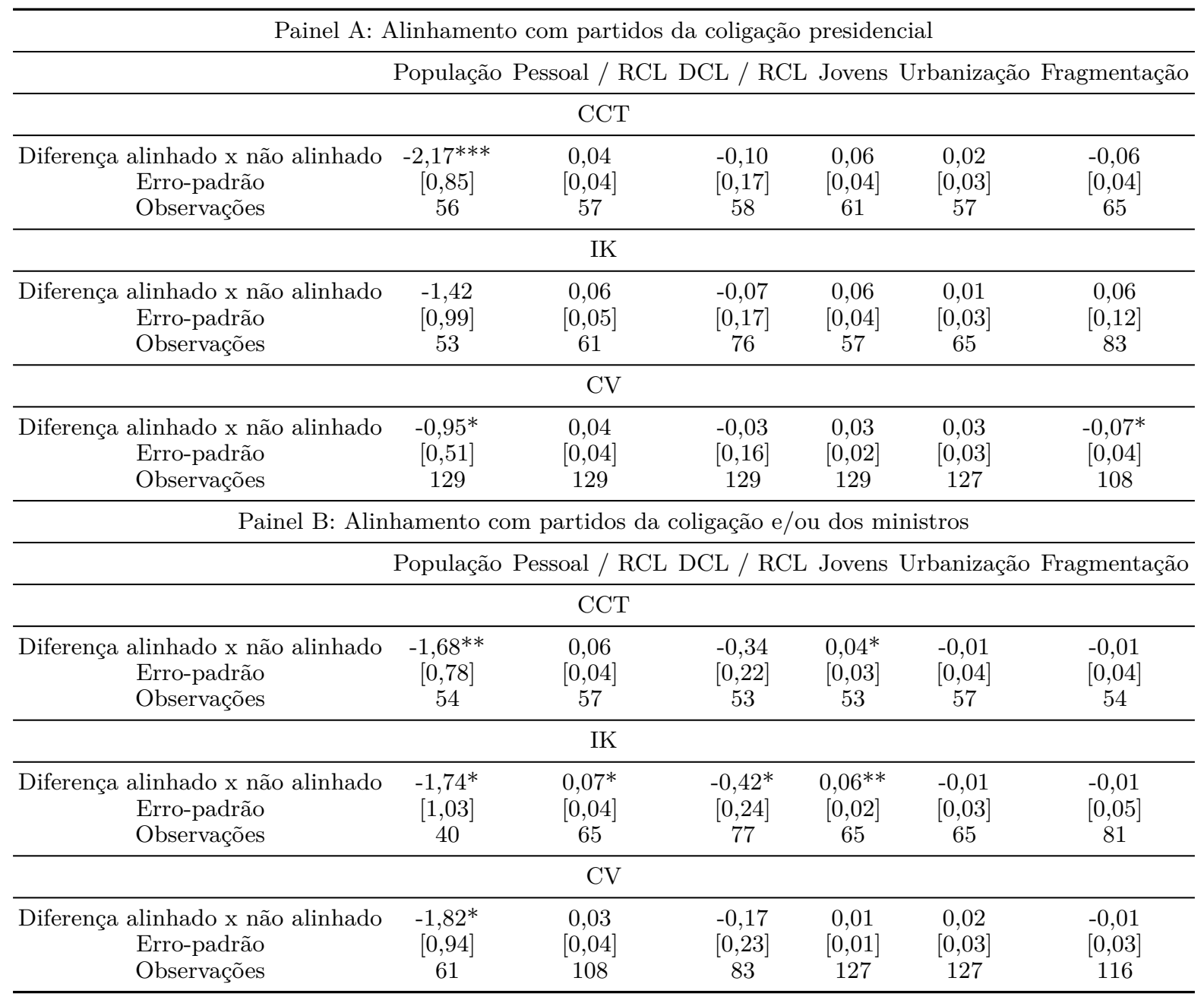

Fonte: elaboração própria

Nota: diferença se refere ao valor da diferença da variável entre unidades alinhadas e não alinhadas em torno da margem de vitória igual a zero; CCT, IK e CV se referem aos métodos de definição da banda (bandwidth) propostos por Calonico, Cattaneo e Titiunik (2014), Imbens e Kalyanaraman (2012) e Ludwig e Miller (2007), respectivamente; ${ }^{* *}=$ Significante a $1 \%{ }^{* *}=$ Significante a $5 \%{ }^{*}=$ Significante a $10 \%$. 
Tabela B.5 - Testes não paramétricos adicionais de descontinuidade - estados

\begin{tabular}{|c|c|c|c|c|c|}
\hline \multicolumn{6}{|c|}{ Painel A: Alinhamento com partidos da coligação presidencial } \\
\hline & Total & \multicolumn{4}{|c|}{ Reembolsável } \\
\hline & $\begin{array}{c}\text { Valor do } \\
\text { financiamento }\end{array}$ & $\begin{array}{c}\text { Valor do } \\
\text { financiamento }\end{array}$ & $\begin{array}{l}\text { Taxa de } \\
\text { juros }\end{array}$ & $\begin{array}{c}\text { Prazo de } \\
\text { amortização }\end{array}$ & $\begin{array}{l}\text { Prazo de } \\
\text { carência }\end{array}$ \\
\hline \multicolumn{6}{|c|}{$\mathrm{CCT}$} \\
\hline $\begin{array}{c}\text { Diferença alinhado x não alinhado } \\
\text { Erro-padrão } \\
\text { Observações }\end{array}$ & $\begin{array}{c}1,37 \\
{[0,89]} \\
77\end{array}$ & $\begin{array}{c}2,41^{* * *} \\
{[0,91]} \\
45\end{array}$ & $\begin{array}{c}-0,89^{*} \\
{[0,52]} \\
59\end{array}$ & $\begin{array}{c}99,46^{* *} \\
{[39,58]} \\
57\end{array}$ & $\begin{array}{c}21,31^{* *} \\
{[9,44]} \\
42\end{array}$ \\
\hline \multicolumn{6}{|c|}{ IK } \\
\hline $\begin{array}{c}\text { Diferença alinhado x não alinhado } \\
\text { Erro-padrão } \\
\text { Observações }\end{array}$ & $\begin{array}{c}2,72^{* *} \\
{[1,30]} \\
54\end{array}$ & $\begin{array}{c}2,65^{* *} \\
{[1,07]} \\
41\end{array}$ & $\begin{array}{c}-1,46^{* *} \\
{[0,72]} \\
44\end{array}$ & $\begin{array}{c}117,93^{* *} \\
{[47,53]} \\
44\end{array}$ & $\begin{array}{c}22,63^{* *} \\
{[10,13]} \\
44\end{array}$ \\
\hline \multicolumn{6}{|c|}{$\mathrm{CV}$} \\
\hline $\begin{array}{c}\text { Diferença alinhado x não alinhado } \\
\text { Erro-padrão } \\
\text { Observações }\end{array}$ & $\begin{array}{c}1,04 \\
{[0,76]} \\
129\end{array}$ & $\begin{array}{c}1,31^{* *} \\
{[0,59]} \\
107\end{array}$ & $\begin{array}{c}-0,85^{* *} \\
{[0,42]} \\
107\end{array}$ & $\begin{array}{c}85,33^{* *} \\
{[36,40]} \\
94\end{array}$ & $\begin{array}{c}6,77 \\
{[5,71]} \\
107\end{array}$ \\
\hline \multicolumn{6}{|c|}{ Painel B: Alinhamento com partidos da coligação e/ou dos ministros } \\
\hline & Total & \multicolumn{4}{|c|}{ Reembolsável } \\
\hline & $\begin{array}{c}\text { Valor do } \\
\text { financiamento }\end{array}$ & $\begin{array}{c}\text { Valor do } \\
\text { financiamento }\end{array}$ & $\begin{array}{l}\text { Taxa de } \\
\text { juros }\end{array}$ & $\begin{array}{c}\text { Prazo de } \\
\text { amortização }\end{array}$ & $\begin{array}{l}\text { Prazo de } \\
\text { carência }\end{array}$ \\
\hline \multicolumn{6}{|c|}{ CCT } \\
\hline $\begin{array}{c}\text { Diferença alinhado x não alinhado } \\
\text { Erro-padrão } \\
\text { Observações }\end{array}$ & $\begin{array}{c}1,89^{* *} \\
{[0,88]} \\
74\end{array}$ & $\begin{array}{c}2,02^{* * *} \\
{[0,75]} \\
58\end{array}$ & $\begin{array}{c}-0,45 \\
{[0,60]} \\
59\end{array}$ & $\begin{array}{c}81,26^{* *} \\
{[38,79]} \\
52\end{array}$ & $\begin{array}{c}10,73 \\
{[8,98]} \\
52\end{array}$ \\
\hline \multicolumn{6}{|c|}{ IK } \\
\hline $\begin{array}{c}\text { Diferença alinhado x não alinhado } \\
\text { Erro-padrão } \\
\text { Observações }\end{array}$ & $\begin{array}{c}3,88^{* *} \\
{[1,68]} \\
74\end{array}$ & $\begin{array}{c}2,26^{* *} \\
{[0,94]} \\
42\end{array}$ & $\begin{array}{c}-1,53 \\
{[0,96]} \\
36\end{array}$ & $\begin{array}{c}100,59^{*} \\
{[55,46]} \\
41\end{array}$ & $\begin{array}{c}21,41 \\
{[13,59]} \\
41\end{array}$ \\
\hline \multicolumn{6}{|c|}{$\mathrm{CV}$} \\
\hline $\begin{array}{c}\text { Diferença alinhado x não alinhado } \\
\text { Erro-padrão } \\
\text { Observações }\end{array}$ & $\begin{array}{c}1,79^{* *} \\
{[0,73]} \\
127\end{array}$ & $\begin{array}{c}1,93^{* * *} \\
{[0,70]} \\
98\end{array}$ & $\begin{array}{c}-0,41 \\
{[0,46]} \\
105\end{array}$ & $\begin{array}{c}90,86^{* *} \\
{[46,34]} \\
63\end{array}$ & $\begin{array}{c}0,63 \\
{[6,54]} \\
105\end{array}$ \\
\hline
\end{tabular}

Fonte: elaboração própria

Nota: as variáveis analisadas nesta tabela são resíduos de regressões das variáveis originais em função das variáveis de controle; Diferença se refere ao valor da diferença da variável entre unidades alinhadas e não alinhadas em torno da margem de vitória igual a zero; CCT, IK e CV se referem aos métodos de definição da banda (bandwidth) propostos por Calonico, Cattaneo e Titiunik (2014), Imbens e Kalyanaraman (2012) e Ludwig e Miller (2007), respectivamente; ${ }^{* * *}=$ Significante a $1 \%{ }^{* *}=$ Significante a $5 \%{ }^{*}=$ Significante a $10 \%$. 


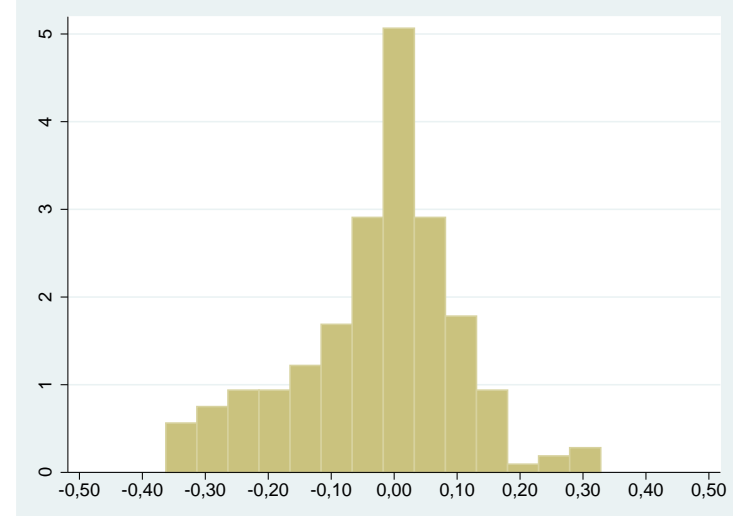

(a) Histograma da proporção de votos - estados

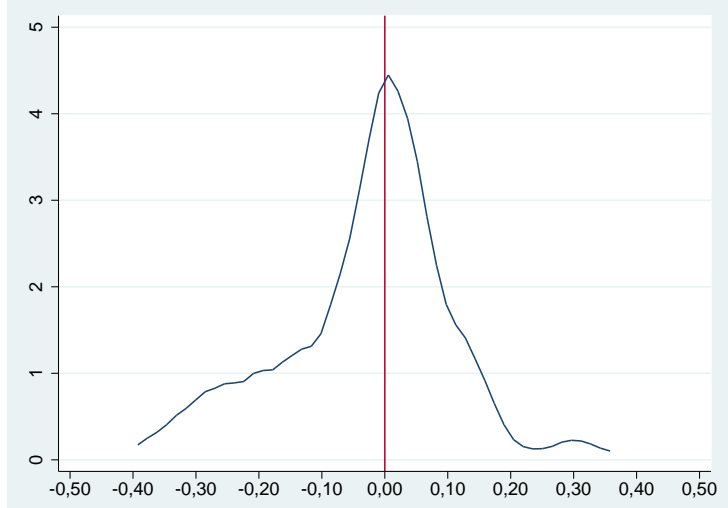

(b) Densidade da proporção de votos - estados

Figura B.14 - Testes de densidade - estados

Fonte: elaboração própria

Nota: valores positivos (à direita do threshold) se referem à proporção recebida de votos por candidatos eleitos e valores negativos (à esquerda do threshold) se referem à proporção recebida de votos pelo segundo melhor colocado, ambos normalizados em torno da margem igual a zero; dados referentes às eleições de 1998, 2002, 2006 e 2010. 
Apêndice C: Tabelas e figuras complementares do Capítulo 4 


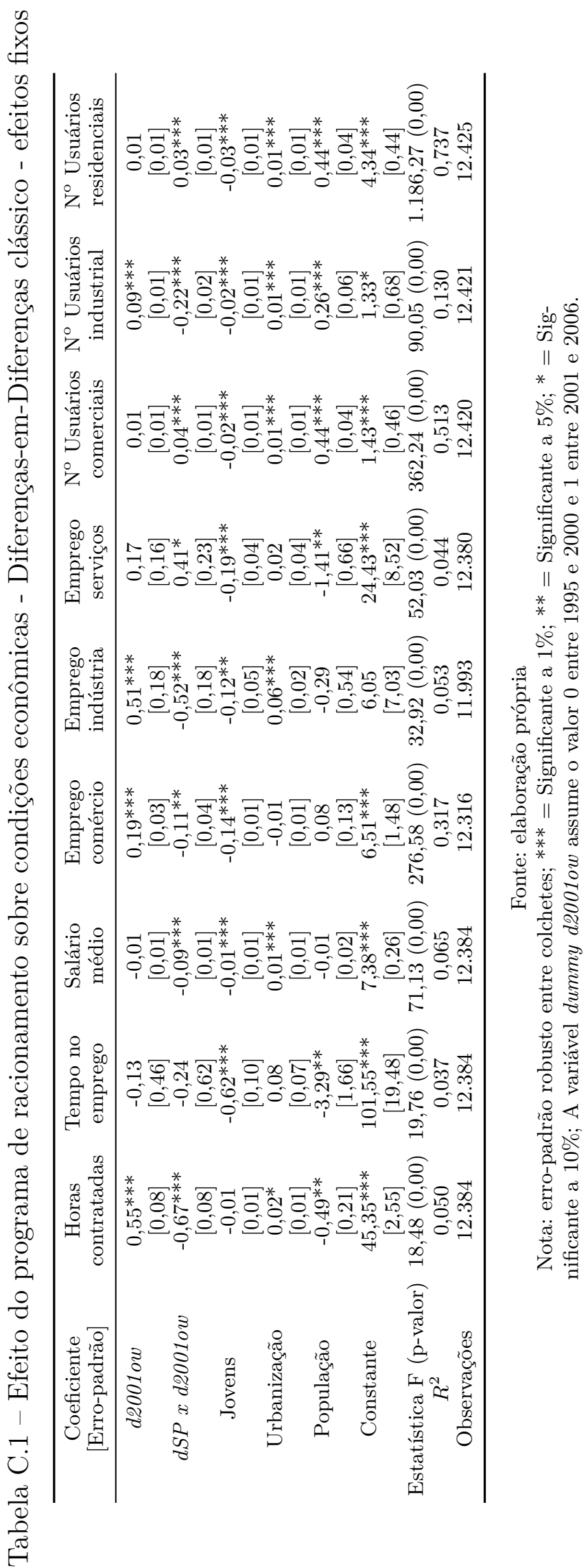


Tabela C.2 - Efeito do programa de racionamento sobre condições econômicas Diferenças-em-Diferenças - efeitos fixos - média dos dois últimos anos do mandato

\begin{tabular}{|c|c|c|c|c|}
\hline $\begin{array}{c}\text { Coeficiente } \\
{[\text { Erro-padrão] }}\end{array}$ & $\begin{array}{c}\text { Horas } \\
\text { contratadas }\end{array}$ & $\begin{array}{l}\text { Salário } \\
\text { médio }\end{array}$ & $\begin{array}{l}\text { Emprego } \\
\text { indústria }\end{array}$ & $\begin{array}{c}\mathrm{N}^{\mathrm{O}} \text { usuários } \\
\text { industriais }\end{array}$ \\
\hline \multirow[t]{2}{*}{ dummy 1996} & $-0,38 * * *$ & $-0,04^{* *}$ & $-0,01$ & $-0,08 * * *$ \\
\hline & {$[0,12]$} & {$[0,02]$} & {$[0,49]$} & {$[0,03]$} \\
\hline \multirow[t]{2}{*}{ dummy 1998} & $-0,22 * * *$ & $0,03 * * *$ & $-0,01$ & $-0,03^{*}$ \\
\hline & {$[0,08]$} & {$[0,01]$} & {$[0,24]$} & {$[0,02]$} \\
\hline \multirow[t]{2}{*}{ dummy 2002} & $0,43^{* * *}$ & $-0,01$ & $0,46^{*}$ & $0,03^{* *}$ \\
\hline & {$[0,08]$} & {$[0,01]$} & {$[0,25]$} & {$[0,01]$} \\
\hline \multirow[t]{2}{*}{ dummy 2004} & $0,68 * * *$ & $0,03 * *$ & $1,03 * *$ & $0,11^{* * *}$ \\
\hline & {$[0,12]$} & {$[0,01]$} & {$[0,49]$} & {$[0,02]$} \\
\hline \multirow[t]{2}{*}{ dummy 2006} & $0,89 * * *$ & $0,12^{* * *}$ & $1,42^{* *}$ & $0,21^{* * *}$ \\
\hline & {$[0,16]$} & {$[0,02]$} & {$[0,71]$} & {$[0,03]$} \\
\hline \multirow[t]{2}{*}{ dummy SP x dummy 1996} & $0,21^{* *}$ & $0,06^{* * *}$ & $0,54^{* * *}$ & $0,03^{*}$ \\
\hline & {$[0,10]$} & {$[0,01]$} & {$[0,15]$} & {$[0,02]$} \\
\hline \multirow[t]{2}{*}{ dummy SP x dummy 1998} & $0,14^{* *}$ & $0,04^{* * *}$ & $0,19^{*}$ & $0,03 * *$ \\
\hline & {$[0,07]$} & {$[0,01]$} & {$[0,11]$} & {$[0,01]$} \\
\hline \multirow[t]{2}{*}{ dummy SP x dummy 2002} & $-0,35 * * *$ & $-0,03^{* * *}$ & $-0,23^{* *}$ & $-0,08 * * *$ \\
\hline & {$[0,08]$} & {$[0,01]$} & {$[0,11]$} & {$[0,01]$} \\
\hline \multirow[t]{2}{*}{ dummy SP x dummy 2004} & $-0,59 * * *$ & $-0,05^{* * *}$ & $-0,47^{* *}$ & $-0,21^{* * *}$ \\
\hline & {$[0,09]$} & {$[0,01]$} & {$[0,20]$} & {$[0,02]$} \\
\hline \multirow[t]{2}{*}{ dummy SP x dummy 2006} & $-0,72^{* * *}$ & $-0,10 * * *$ & $-0,13$ & $-0,35^{* * *}$ \\
\hline & {$[0,11]$} & {$[0,01]$} & {$[0,33]$} & {$[0,02]$} \\
\hline \multirow[t]{2}{*}{ Jovens } & $0,05^{*}$ & $-0,01$ & 0,01 & $-0,01$ \\
\hline & {$[0,03]$} & {$[0,01]$} & {$[0,16]$} & {$[0,01]$} \\
\hline \multirow[t]{2}{*}{ Urbanização } & 0,01 & $0,01 * * *$ & $0,08 * * *$ & $0,01 * * *$ \\
\hline & {$[0,01]$} & {$[0,01]$} & {$[0,02]$} & {$[0,01]$} \\
\hline \multirow[t]{2}{*}{ População } & $-0,63^{* *}$ & 0,02 & $-0,01$ & $0,35 * * *$ \\
\hline & {$[0,26]$} & {$[0,03]$} & {$[0,71]$} & {$[0,07]$} \\
\hline \multirow[t]{2}{*}{ Constante } & $45,02^{* * *}$ & $6,67 * * *$ & $-2,76$ & 0,10 \\
\hline & {$[3,04]$} & {$[0,30]$} & {$[10,29]$} & {$[0,77]$} \\
\hline$R^{2}$ & 0,275 & 0,167 & 0,284 & 0,190 \\
\hline Observações & 6.264 & 6.264 & 6.264 & 6.264 \\
\hline
\end{tabular}

Fonte: elaboração própria

Nota: erro-padrão robusto entre colchetes; $* * *=$ Significante a $1 \% ;{ }^{* *}=$ Significante a $5 \%{ }^{*}=$ Significante a $10 \%$. 
Tabela C.3 - Efeito do programa de racionamento sobre condições econômicas Diferenças-em-Diferenças - efeitos fixos - variação proporcional entre a média dos dois primeiros e a média dos dois últimos anos do mandato

\begin{tabular}{|c|c|c|c|c|}
\hline $\begin{array}{c}\text { Coeficiente } \\
{[\text { Erro-padrão] }}\end{array}$ & $\begin{array}{c}\text { Horas } \\
\text { contratadas }\end{array}$ & $\begin{array}{l}\text { Salário } \\
\text { médio }\end{array}$ & $\begin{array}{l}\text { Emprego } \\
\text { indústria }\end{array}$ & $\begin{array}{c}\mathrm{N}^{\circ} \text { usuários } \\
\text { industriais }\end{array}$ \\
\hline dummy 1996 & - & $\begin{array}{c}25,80^{* * *} \\
{[2,37]}\end{array}$ & $\begin{array}{l}-17,85 \\
{[21,45]}\end{array}$ & $\begin{array}{c}7,65^{* * *} \\
{[2,43]}\end{array}$ \\
\hline dummy 1998 & $\begin{array}{l}-0,22 \\
{[0,30]}\end{array}$ & $\begin{array}{c}4,82^{* * *} \\
{[1,42]}\end{array}$ & $\begin{array}{c}24,58 \\
{[19,33]}\end{array}$ & $\begin{array}{c}4,10^{* *} \\
{[2,01]}\end{array}$ \\
\hline dummy 2002 & $\begin{array}{l}0,53^{*} \\
{[0,27]}\end{array}$ & $\begin{array}{c}1,37 \\
{[1,30]}\end{array}$ & $\begin{array}{c}37,10^{* *} \\
{[16,44]}\end{array}$ & $\begin{array}{c}-3,73^{* *} \\
{[1.71]}\end{array}$ \\
\hline dummy 2004 & $\begin{array}{c}0,11 \\
{[0,31]}\end{array}$ & $\begin{array}{c}{[1,30]} \\
0,33 \\
{[1,35]}\end{array}$ & $\begin{array}{c}{[10,44]} \\
10,43 \\
{[18,89]}\end{array}$ & $\begin{array}{c}{[1,43]} \\
1,43 \\
{[2,73]}\end{array}$ \\
\hline dummy 2006 & $\begin{array}{c}0,08 \\
{[0,43]}\end{array}$ & $\begin{array}{c}10,30 * * * \\
{[1,69]}\end{array}$ & $\begin{array}{l}17,71 \\
{[25,55]}\end{array}$ & $\begin{array}{c}2,83 \\
{[3,08]}\end{array}$ \\
\hline dummy SP x dummy 1996 & - & $\begin{array}{c}10,78^{* * *} \\
{[2,27]}\end{array}$ & $\begin{array}{c}30,70 \\
{[25,46]}\end{array}$ & $\begin{array}{c}1,95 \\
{[2,30]}\end{array}$ \\
\hline dummy SP x dummy 1998 & $\begin{array}{c}0,18 \\
{[0,27]}\end{array}$ & $\begin{array}{c}4,75^{* * *} \\
{[1,51]}\end{array}$ & $\begin{array}{c}8,01 \\
{[31,04]}\end{array}$ & $\begin{array}{c}1,32 \\
{[2,23]}\end{array}$ \\
\hline dummy SP x dummy 2002 & $\begin{array}{c}-0,39^{* *} \\
{[0,19]}\end{array}$ & $\begin{array}{c}-3,31^{* *} \\
{[1,51]}\end{array}$ & $\begin{array}{c}-16,28^{* *} \\
{[8,15]}\end{array}$ & $\begin{array}{c}-3,75^{* *} \\
{[1,85]}\end{array}$ \\
\hline dummy SP x dummy 2004 & $\begin{array}{l}-0,05 \\
{[0,23]}\end{array}$ & $\begin{array}{c}3,15^{* *} \\
{[1,31]}\end{array}$ & $\begin{array}{c}15,23 \\
{[16,69]}\end{array}$ & $\begin{array}{c}-10,43^{* * *} \\
{[2,43]}\end{array}$ \\
\hline dummy SP x dummy 2006 & $\begin{array}{c}0,26 \\
{[0,23]}\end{array}$ & $\begin{array}{c}0,38 \\
{[1,26]}\end{array}$ & $\begin{array}{c}32,31 \\
{[23,17]}\end{array}$ & $\begin{array}{c}-11,10^{* * * *} \\
{[2,42]}\end{array}$ \\
\hline Jovens & $\begin{array}{l}0,05 \\
{[0,08]}\end{array}$ & $\begin{array}{l}-0,23 \\
{[0,37]}\end{array}$ & $\begin{array}{c}2,13 \\
{[5,38]}\end{array}$ & $\begin{array}{l}-0,91 \\
{[0,58]}\end{array}$ \\
\hline Urbanização & $\begin{array}{c}0,01 \\
{[0,03]}\end{array}$ & $\begin{array}{l}-0,12 \\
{[0,11]}\end{array}$ & $\begin{array}{l}-4,79^{*} \\
{[2,80]}\end{array}$ & $\begin{array}{l}-0,17 \\
{[0,17]}\end{array}$ \\
\hline População & $\begin{array}{l}-1,00 \\
{[1,21]}\end{array}$ & $\begin{array}{l}-7,48 \\
{[4,98]}\end{array}$ & $\begin{array}{l}-154,06 \\
{[230,20]}\end{array}$ & $\begin{array}{c}-10,57^{*} \\
{[5,72]}\end{array}$ \\
\hline Constante & $\begin{array}{c}7,03 \\
{[12,71]}\end{array}$ & $\begin{array}{l}85,71^{*} \\
{[51,97]}\end{array}$ & $\begin{array}{c}1.773,80 \\
{[2.279,42]}\end{array}$ & $\begin{array}{c}152,19^{* *} \\
{[62,37]}\end{array}$ \\
\hline$R^{2}$ & 0,255 & 0,360 & 0,277 & 0,188 \\
\hline Observações & 6.264 & 6.264 & 6.264 & 6.264 \\
\hline
\end{tabular}

Fonte: elaboração própria

Nota: erro-padrão robusto entre colchetes; $* * *=$ Significante a $1 \%$; $* *=$ Significante a $5 \%$; $=$ Significante a $10 \%$. Não há dados disponíveis de horas contratadas para o ano de 1993, o que impossibilita o cálculo da variação proporcional entre a média de 1993 e 1994 e a média de 1995 e 1996. 